
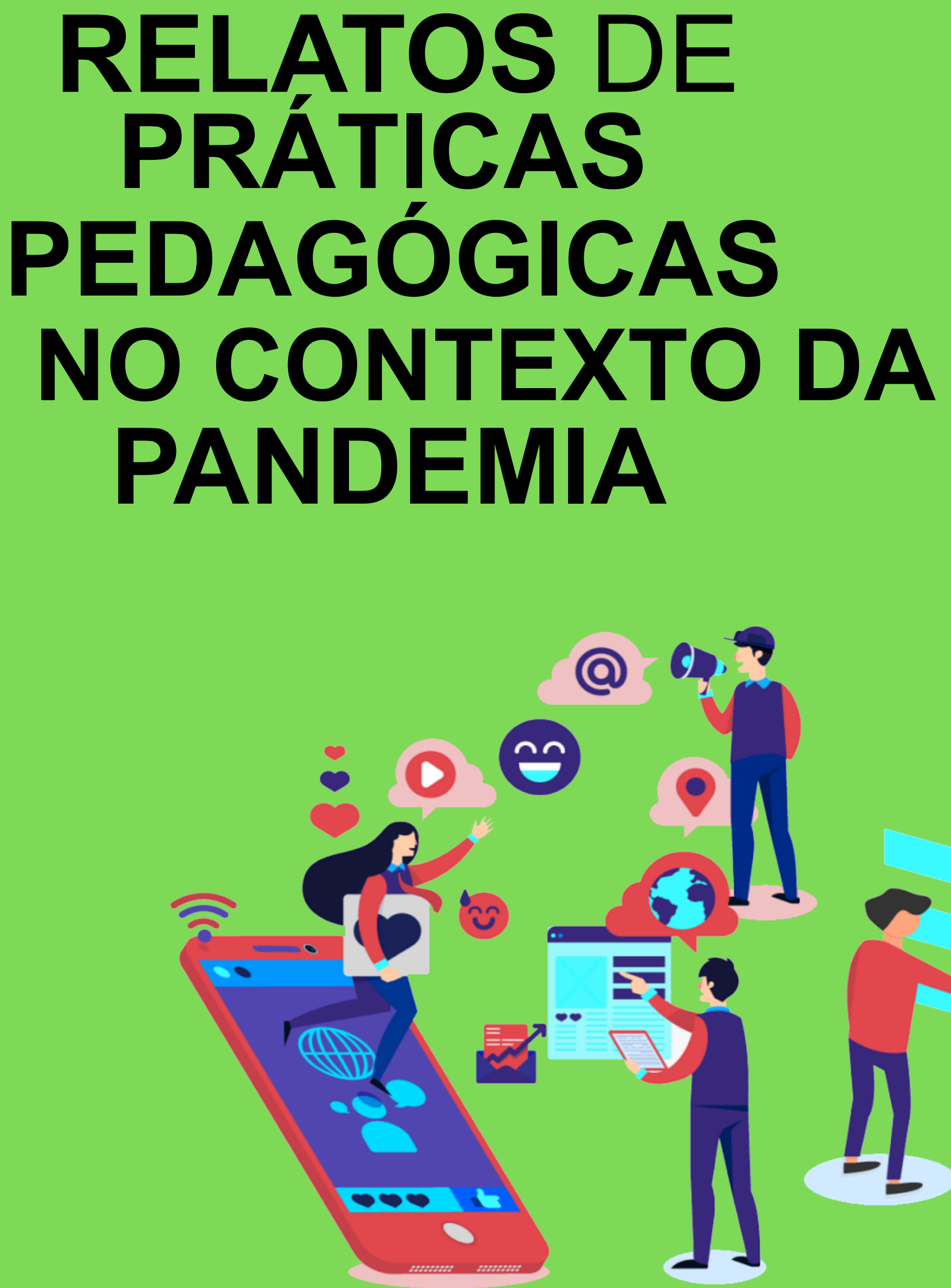

x

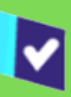

8

Rosiele Oliveira da Encarnação Keiciane Canabarro Drehmer-Marques José Francisco Zavaglia Marques 

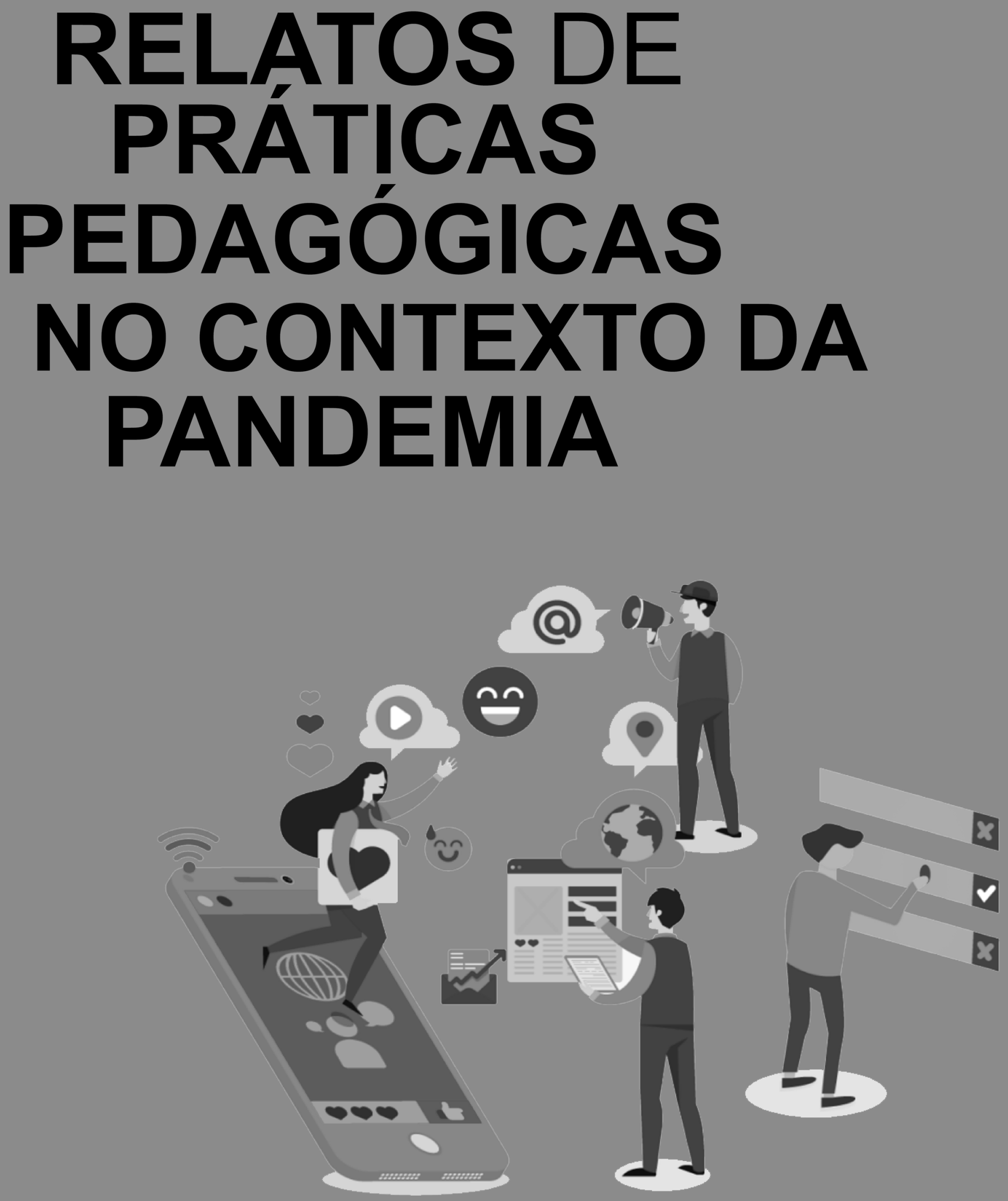

Rosiele Oliveira da Encarnação Keiciane Canabarro Drehmer-Marques José Francisco Zavaglia Marques

[Organizadores] 


\section{CONSELHO EDITORIAL}

Prof. Dr. Adilson Tadeu Basquerot e Silva

UNIDAVI/SC

http://lattes.cnpq.br/8318350738705473

Profa. Msc. Jesica Wendy Beltrán

UFCE- Colômbia

http://lattes.cnpq.br/0048679279914457

Profa. Dra Fabiane dos Santos Ramos UFSM- Santa Maria/RS

http://lattes.cnpq.br/0003382878348789

Dr. João Riél Manuel Nunes Vieira de

Oliveira Brito

UAL - Lisboa- Portugal.

http://lattes.cnpq.br/1347367542944960

Profa. Dra. Alessandra Regina Müller Germani

UFFS- Passo Fundo/RS

http://lattes.cnpq.br/7956662371295912

Prof. Dr. Everton Bandeira Martins

UFFS - Chapecó/SC

http://lattes.cnpq.br/9818548065077031

Prof. Dr. Erick Kader Callegaro Corrêa UFN- Santa Maria/RS

http://lattes.cnpq.br/2363988112549627

Prof. Dr. Pedro Henrique Witchs

UFES - Vitória/ES

http://lattes.cnpq.br/3913436849859138

Prof. Dr.Thiago Ribeiro Rafagnin UFOB

http://lattes.cnpq.br/3377502960363268
Prof. Dr. Mateus Henrique Köhler UFSM- Santa Maria/RS http://lattes.cnpq.br/5754140057757003

Profa. Dra. Liziany Müller Medeiros UFSM- Santa Maria/RS http://lattes.cnpq.br/1486004582806497

Prof. Dr. Camilo Darsie de Souza UNISC- Santa Cruz do Sul/RS http://lattes.cnpq.br/4407126331414

Prof. Dr. Dioni Paulo Pastorio UFRGS - Porto Alegre/RS http://lattes.cnpq.br/7823646075456872

Prof. Dr. Leonardo Bigolin Jantsch UFSM- Palmeira das Missões/RS http://lattes.cnpq.br/0639803965762459

Prof. Dr. Leandro Antônio dos Santos UFU- Uberlândia/MG http://lattes.cnpq.br/4649031713685124

Dr. Rafael Nogueira Furtado UFJF- Juiz de Fora/MG http://lattes.cnpq.br/9761786872182217

Profa. Dra. Angelita Zimmermann UFSM- Santa Maria/RS http://lattes.cnpq.br/7548796037921237

Profa. Dra. Francielle Benini Agne Tybusch

UFN - Santa Maria/RS http://lattes.cnpq.br/4400702817251869

Copyright (C) Arco Editora, alguns direitos reservados.

Copyright do texto (c) 2021 os autores e as autoras.

Copyright da edição (c) 2021 Arco Editora. 
Diagramação e Projeto Gráfico : Gabriel Eldereti Machado imagem capa: $w w w$. pixabay.com

Revisão: dos/as autores/as.

Dados Internacionais de Catalogação na Publicação (CIP) (Câmara Brasileira do Livro, SP, Brasil)

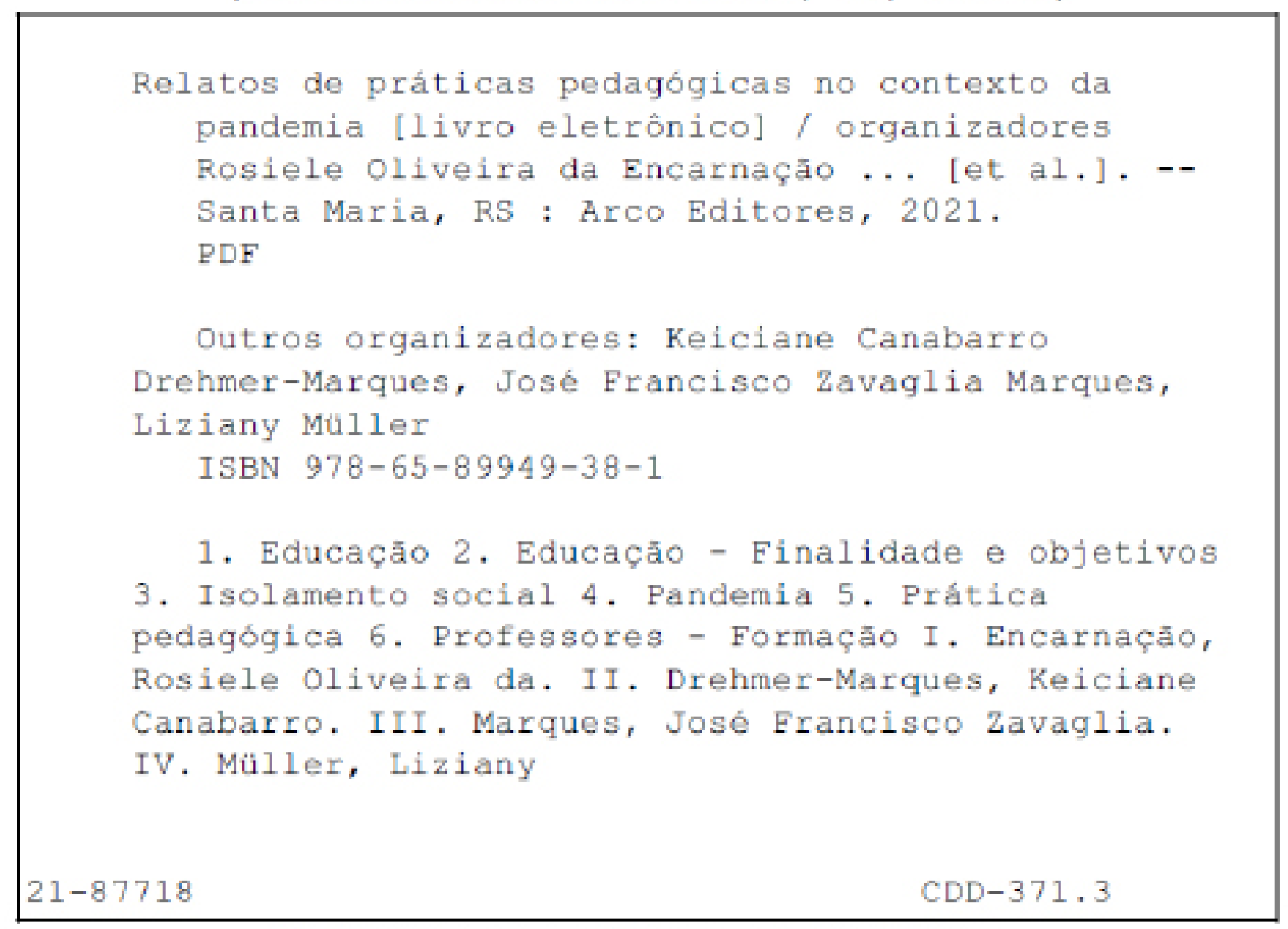

Indices para catálogo sistemático:

1. Prática pedagógica : Educaçāo 371.3

Maria Alice Ferreira - Bibliotecária - CRB-8/7964

\subsection{9/978-65-89949-38-1}

O padrão linguístico-gramatical, bem como o sistema de citações e referências bibliográficas são prerrogativas de cada autor. Da mesma maneira, o conteúdo e teor de cada capítulo é de inteira e exclusiva responsabilidade de seu respectivo autor. 


\section{APRESENTAÇÃO}

A pandemia do novo Coronavírus deixou os espaços educacionais com inúmeras incertezas, em que tiveram que se adaptar de maneira abrupta a fim de adequar-se à nova realidade, com a reclusão das pessoas em suas residências em um período de isolamento físico para evitar a propagação da COVID-19. Neste contexto, muitas instituições de ensino tiveram que adotar o ensino remoto para continuar com as atividades acadêmicas/escolares, tal processo, deixou aparente fragilidades, dificuldades e desafios para que os professores e professoras pudessem desenvolver suas aulas.

Esse novo formato foi construído e organizado às pressas, sem um tempo de preparação dos estudantes, professores e gestores. Desta forma, desafiando os ambientes educacionais a construir alternativas para viabilizar o desenvolvimento do ano letivo, buscando de forma mais igualitária possível garantir a qualidade e equidade de acesso ao modelo remoto, a fim de proporcionar a formação dos educandos e assim dar continuidade ao ensino durante o período de distanciamento físico.

O ensino remoto transformou a sala de aula física em um ambiente virtual, acentuando as dificuldades persistentes e recorrentes na educação do nosso país, sendo que a principal limitação esteve atrelada a exclusão digital dos sujeitos que não possuem acesso à internet, nem dispunham de equipamentos como computador, tablet, televisão ou smartphone. Somado a isto, está a carência de uma formação inicial e continuada para os docentes, sobre o domínio das tecnologias digitais (TD).

Apesar disso, também temos o envolvimento destes profissionais para o (re)planejamento e elaboração de diversas estratégias para que suas práticas pedagógicas atendessem o maior número possível de estudantes mantendo a qualidade do ensino durante a pandemia. As estratégias adotadas pelos professores e professoras foram diversas, em algumas situações o uso da transmissão de aulas por canais de televisão, rádio, YouTube, comunicação por e-mail, Face- 
book, WhatsApp e até mesmo o envio de material impresso para os estudantes representando as diferentes realidades e contextos no nosso país.

A obra Relatos de práticas pedagógicas no contexto da pandemia é composta por 12 capítulos que discorrem sobre relatos de diferentes áreas do conhecimento dos cenários de Ensino Superior e Educação Básica vivenciadas no momento pandêmico imposto pela COVID-19.

O primeiro capítulo dos autores Rosiele Oliveira da Encarnação, Keiciane Canabarro Drehmer-Marques, Raiane da Rosa Dutra, José Francisco Zavaglia Marques e Liziany Müller com o texto Compartilhando vivências do Projeto Tecnologias Digitais na Educação Básica. Os pesquisadores relatam a implementação e o perfil do público participante de cinco cursos de "Tecnologias Digitais na Educação Básica" oferecido pela Universidade Federal de Santa Maria aos professores e professoras da Educação Básica buscando subsidiar os docentes no ensino remoto e/ou híbrido quanto aos recursos e ferramentas digitais.

Em Relato de experiência na Residência Pedagógica: Uma perspectiva de ensino durante a pandemia do Coronavírus, Flávio José de Carvalho Sousa, Haroldo Reis Alves de Macêdo, Italo Marcos de Lima e Antônio Amadeus Mendes Gonçalves relatam a experiência, vivenciada no Programa de Residência Pedagógica do Instituto Federal de Educação, Ciência e Tecnologia do Piauí (IFPI) - Campus Picos. Os autores descrevem o desenvolvimento de aulas e demais atividades onlines com a utilização de vídeos, simuladores entre outros de forma remota com uso das tecnologias para fins educacionais.

O terceiro capítulo Educação em tempos de pandemia: O uso das mídias no processo de ensino de Joice Vareiro da Costa Brites e Priscilla Basmage Lemos Drulis, apresenta uma análise do novo contexto social e cultural, no que refere-se aos impactos da pandemia no meio escolar, como também as influências de meios de tecnologia no uso do novo formato educacional. As autoras discorrem sobre o uso de diferentes plataformas para fins educacionais como o Youtube, Google Meet e o aplicativo Whatsapp. 
Ensino remoto na UFSM: opiniões dos alunos ingressantes sobre o Rederegime de exercícios domiciliares especiais é o título do quarto capítulo, que tem a autoria de Sidnei Renato Silveira e Antônio Rodrigo Delepiane de Vit. O texto discorre sobre as opiniões dos acadêmicos do Curso de Bacharelado em Sistemas de Informação da Universidade Federal de Santa Maria - Campus Frederico Westphalen/RS acerca da modalidade de ensino remoto denominada REDE - Regime de Exercícios Domiciliares Especiais, adotada durante o período de isolamento social devido à pandemia de COVID-19.

As autoras do quinto capítulo Luciane Schlottfeldt e Janilce Nunes contribuem com o texto $O$ uso das tecnologias digitais da informação e comunicação como mediadoras no processo de ensino e aprendizagem em uma Escola do Campo. A escrita relata a experiência dos educadores que buscam associar os conhecimentos teóricos de sala de aula em conjunto com os saberes tradicionais do campo utilizando as Tecnologias Digitais de Informação e Comunicação como ferramentas de apoio pedagógico na construção de aprendizagens ativas pela estratégia educacional Team-Based Learning (TBL) em uma Escola do Campo.

Ensino remoto: Google Earth como possibilidade metodológica para o ensino de Geografia da autoria de Cícero Antonio Jatanael da Silva Tavares relata o uso do Google Earth como recurso didático para o ensino de Geografia. O pesquisador destaca que a atividade realizada virtualmente e a discussão do conteúdo não foi prejudicada por ocorrer de forma remota.

O sétimo capítulo intitulado Utilização de imagens na Aprendizagem Baseada em Problemas (ABP) na concepção de pós-graduandos da autoria de Luana Ehle Joras e Darlize Déglan Borges Beulck Bender. O texto discorre sobre as concepções de Pós-Graduandos sobre a utilização de imagens na Abordagem Baseada em Problemas (ABP). A experiência foi relatada por meio da implementação de uma oficina virtual no evento Ciência em Ação: Educar é Transformar.

Thayane Azevedo Pereira de Souza é a autora do texto $O$ atendimento educacional especializado em parceria com a classe comum: Um enriquecimento curricular para todos. O capítulo apresenta adaptações, possibilidades e de- 
safios de estratégias pedagógicas adotadas no contexto pandêmico realizadas pelo Colégio Universitário Geraldo Reis (Coluni-UFF), vinculado à Universidade Federal Fluminense.

O capítulo nove, Projeto invasão cultural: novas emissões e percepções da autoria de Laercio Fernandes dos Santos, discorre sobre um relato de uma prática pedagógica na área das Linguagens. A atividade realizada anteriormente de forma presencial, a mesma foi ressignificada para o formato remoto, demonstrando a possibilidade da vivência significativa na e pela linguagem, numa experiência de vocalização do texto poético. A prática envolve turmas do Ensino Médio no projeto de vocalização intitulado Invasão Cultural, o qual busca contemplar a experiência singular do falante com a língua, mesmo durante o período pandêmico

Oralidade \& Ensino: Pontes construídas com a contação de história é o décimo capítulo da obra, cuja autora Jaqueline Estácio Barbosa de Jesus Santos aponta reflexões sobre os aspectos do texto oral para o ensino de língua, tendo em vista, que na história tradicional dos estudos linguísticos. Na escrita considera-se a relevância da prática oral da contação de história na vida diária da criança, principalmente, no período atual de pandemia de COVID-19.

No texto Ensino remoto e aprendizagem digital em Língua Portuguesa: uma proposta metodológica de Walter Duarte Monteiro Neto e Aline Kerber Bruniczak objetivam apresentar uma sugestão de proposta metodológica utilizando objetos de aprendizagem digitais (OAD) para o Ensino de Língua Portuguesa a ser implantada no Ensino Fundamental nas turmas de $5^{\circ}$ e $6^{\circ}$ ano. O capítulo apresenta ainda o conceito dos objetos de aprendizagem digitais, pesquisa em sites e repositórios gratuitos de objetos de aprendizagem digitais e alinhamento da proposta com a Base Nacional Comum Curricular (BNCC).

O último capítulo da obra Escrita crítica: $A$ construção do corpo escritor em linhas transversais em tempo pandêmicos do autor Waldenilson Teixeira Ramos, relata as experiências de práticas pedagógicas dentro do campo da escrita e os desafios de efetivar uma práxis de cunho crítico em tempos pandêmicos. $O$ 
pesquisador relata os desafios do contexto atual devido a COVID-19 e novas possibilidades inventivas de vínculo com os educandos.

E assim, finalizamos a obra Relatos de práticas pedagógicas no contexto da pandemia, com a reunião de 12 relatos de práticas pedagógicas em diferentes níveis e modalidades de ensino, que abordam experiências inovadoras de processos de ensino e aprendizagem durante o período pandêmico. Neste sentido, temos o intuito de provocar, incentivar, motivar e entusiasmar os professores e professoras, leitores da obra, para que construam e realizem práticas criativas em seus ambientes de trabalho.

O livro apresenta estratégias e possibilidades de propostas construídas durante o período pandêmico. Ademais, é um convite para refletir, adaptar, ter novas percepções, abordagens e ferramentas que serão incorporados no processo de formação do sujeito durante o retorno ao ensino presencial.

Rosiele Oliveira da Encarnação

Keiciane Canabarro Drehmer-Marques

José Francisco Zavaglia Marques

Liziany Müller

(Organizadores) 


\section{SUMÁRIO}

\section{CAPÍTULO 1}

\section{COMPARTILHANDO VIVÊNCIAS DO PROJETO TECNOLOGIAS}

DIGITAIS NA EDUCAÇÃO BÁSICA

Rosiele Oliveira da Encarnação

Keiciane Canabarro Drehmer-Marques

Raiane da Rosa Dutra

José Francisco Zavaglia Marques

Liziany Müller

doi: 10.48209/978-65-89949-38-2

\section{CAPÍTULO 2}

RELATO DE EXPERIÊNCIA NA RESIDÊNCIA PEDAGÓGICA: UMA PERSPECTIVA DE ENSINO DURANTE A PANDEMIA DO CORONAVÍRUS

Flávio José de Carvalho Sousa

Antônio Amadeus Mendes Gonçalves

Haroldo Reis Alves de Macêdo

Italo Marcos de Lima

doi: 10.48209/978-65-89949-38-3

\section{CAPÍTULO 3}

EDUCAÇÃO EM TEMPOS DE PANDEMIA: O USO DAS MÍDIAS NO PROCESSO DE ENSINO.

Joice Vareiro da Costa Brites

Priscilla Basmage Lemos Drulis

doi: 10.48209/978-65-89949-38-4

\section{CAPÍTULO 4}

ENSINO REMOTO NA UFSM: OPINIÕES DOS ALUNOS INGRESSANTES SOBRE O REDE - REGIME DE EXERCÍCIOS DOMICILIARES ESPECIAIS

Sidnei Renato Silveira

Antônio Rodrigo Delepiane de Vit

doi: 10.48209/978-65-89949-38-5 
CAPÍtulO 5

O USO DAS TECNOLOGIAS DIGITAIS DA INFORMAÇÃO E COMUNICAÇÃO COMO MEDIADORAS NO PROCESSO DE ENSINO E APRENDIZAGEM EM UMA ESCOLA DO CAMPO. .74

Luciane M. Schlottfeldt

Janilse. F. Nunes

doi: 10.48209/978-65-89949-38-6

CAPÍtuLO 6

ENSINO REMOTO: GOOGLE EARTH COMO POSSIBILIDADE METODOLÓGICA PARA O ENSINO DE GEOGRAFIA.............................87

Cícero Antonio Jatanael da Silva Tavares

doi: 10.48209/978-65-89949-38-7

\section{CAPÍTULO 7}

UTILIZAÇÃO DE IMAGENS NA APRENDIZAGEM BASEADA EM PROBLEMAS (ABP) NA CONCEPÇÃO DE PÓS-GRADUANDOS.............101

Luana Ehle Joras

Darlize Déglan Borges Beulck Bender

doi: 10.48209/978-65-89949-38-8

\section{CAPÍTULO 8}

O ATENDIMENTO EDUCACIONAL ESPECIALIZADO EM PARCERIA COM A CLASSE COMUM: UM ENRIQUECIMENTO CURRICULAR PARA TODOS. 118

Thayane Azevedo Pereira de Souza

doi: 10.48209/978-65-89949-38-9

\section{CAPÍTULO 9}

PROJETO INVASÃO CULTURAL: NOVAS EMISSÕES E PERCEPÇÕES..134

Laercio Fernandes dos Santos

doi: 10.48209/978-65-89949-38-0 


\section{CAPÍTULO 10}

ORALIDADE \& ENSINO: PONTES CONSTRUIDAS COM A CONTAÇÃO DE HISTÓRIA 146

Jaqueline Estácio Barbosa de Jesus Santos

doi: 10.48209/978-65-89949-11-1

\section{CAPÍTULO 11}

ENSINO REMOTO E APRENDIZAGEM DIGITAL EM LÍNGUA PORTUGUESA: UMA PROPOSTA METODOLÓGICA.

Walter Duarte Monteiro Neto

Aline Kerber Bruniczak

doi: 10.48209/978-65-89949-12-1

\section{CAPÍTULO 12}

ESCRITA CRÍTICA: A CONSTRUÇÃO DO CORPO ESCRITOR EM LINHAS TRANSVERSAIS EM TEMPO PANDÊMICOS.

Waldenilson Teixeira Ramos

doi: 10.48209/978-65-89949-13-1

SOBRE OS ORGANIZADORES 


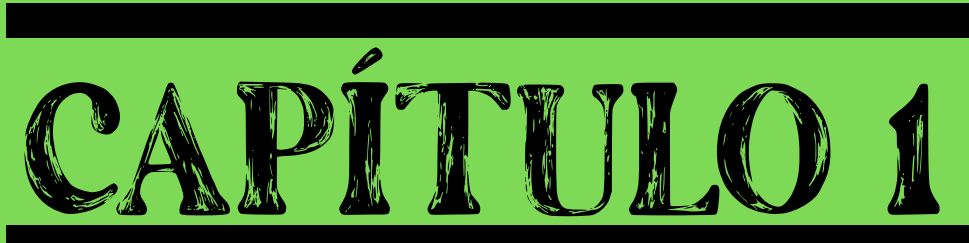

\section{COMPARTILHANDO VIVÊNCIAS DO PROJETO TECNOLOGIAS DIGITAIS NA EDUCAÇÃO BÁSICA}

Rosiele Oliveira da Encarnação Keiciane Canabarro Drehmer-Marques Raiane da Rosa Dutra José Francisco Zavaglia Marques Liziany Müller 


\section{INTRODUÇÃO}

Em março de 2020, com o intuito de frear os índices recorrentes de contaminação pelo novo Coronavírus, foi necessário realizar o fechamento das escolas e construir um novo modelo de ensino na Educação Básica, a distância. Neste contexto,

"[...] surgem cursos on-line, palestras ao vivo (lives), formações aligeiradas, aulas virtuais para que a educação escolar aconteça. Em algumas situações, ocorre a imposição do uso de tecnologias digitais, sem a devida orientação ou formação para os docentes" (SENRA; SILVA, 2020, p. 101772).

Desta maneira, mostra-se relevante refletir sobre as fragilidades da formação docente, assim como sobre a importância da formação continuada, especialmente neste cenário atípico, em que os professores precisaram reinventar-se para um novo formato de ensino. Drehmer-Marques e Tolentino-Neto (2021) salientam que o processo de formação docente é eternamente inacabado, uma vez que a profissão requer constantes atualizações e adaptações metodológicas, de avaliação e em demais aspectos. Consequentemente, "no caso da educação, vários pontos têm se mostrado frágeis, como a incorporação para o uso das tecnologias digitais (TD)" (FERREIRA et al., 2020, p. 3).

As Tecnologias Digitais da Informação e Comunicação (TDIC) nunca se fizeram tão necessárias como no contexto em que estamos vivendo. Com aulas remotas/ensino híbrido, as ferramentas digitais mostraram-se como indispensáveis para que o processo de ensino e aprendizagem não fosse prejudicado, visto que elas "[...] permitem, hoje, ministrar uma aula de forma muito mais dinâmica, interativa e colaborativa" (SCHUARTZ, 2020, p. 430), contudo, "exige-se repensar as práticas pedagógicas existentes, o que se mostra um desafio aos docentes na contemporaneidade: agregar às práticas de ensino e aprendizagem recursos disponíveis em TDIC" (SCHUARTZ, 2020, p. 430).

A formação dos professores com o apoio das TDIC possibilita a democratização do acesso, a atualização permanente e a adoção de novos paradigmas educacionais, com desenvolvimento da autonomia do buscar, criar e intervir no 
mundo em que vivemos. O acesso e o amparo voltado ao uso de ferramentas e recursos digitais, durante os cursos de formação, podem oportunizar aos professores acrescentar e modificar as suas concepções e favorecer ampliação e mudanças nas atividades realizadas no ensino e "[...] assim, quanto mais contato com os recursos, mais familiaridade o usuário adquire e com isso as possibilidades de uso se ampliam" (MODELSKI; GIRAFFA; CASARTELLI, 2019, p. 6).

Em busca da inovação e da ampliação das competências tecnológicas, que são um conjunto de conhecimentos, habilidades e atitudes para resolver problemas em meio digital para os docentes e discentes, desenvolvemos os cursos com recursos e ferramentas digitais. Tais cursos objetivam auxiliar no ensino e na aprendizagem dentro das atividades de organização, planejamento, implementação e avaliação das aulas remotas, híbridas e presenciais. Essas atividades podem ampliar a interação, a colaboração, a participação entre docente-discente e discente-discente na construção e na comunicação dos conhecimentos trabaIhados em seus diferentes níveis de ensino e disciplinas. Portanto, o presente capítulo tem como objetivo relatar algumas das características do perfil do público participante e as ações do projeto "Tecnologias Digitais na Educação Básica", ofertado pela Universidade Federal de Santa Maria (UFSM).

\section{DESENVOLVIMENTO}

A UFSM em rede, em 2020, trouxe algumas demandas urgentes para serem trabalhadas no ambiente da universidade, especialmente, referente à utilização de ferramentas e tecnologias digitais, a fim de viabilizar o desenvolvimento das atividades acadêmicas e administrativas para os servidores da instituição. Desta forma, foi produzido e desenvolvido o projeto de capacitação denominado "Fluência tecnológica no AVEA Moodle para o planejamento de disciplinas no ensino remoto", implementado em 2020 e 2021 (DREHMER-MARQUES et al., 2021) e, baseado nessa experiência, voltamos nosso olhar para a Educação Básica, a qual, no momento, também estava imersa no ensino remoto e nos primei- 
ros passos para o ensino híbrido. Pensando no referido contexto, organizamos, estruturamos e construímos as ações práticas.

O projeto "Tecnologias Digitais na Educação Básica" foi desenvolvido por uma equipe de estudantes, Técnicos Administrativos em Educação (TAEs), docentes e demais colaboradores da Universidade Federal de Santa Maria, em parceria com a Pró-Reitoria de Extensão UFSM, através dos projetos institucionais "Geoparque Quarta Colônia" e "Geoparque Caçapava”. Os cursos ofertados foram voltados aos professores da Educação Básica, pois devido ao prolongamento da pandemia do novo Coronavírus, a formação buscou subsidiar os docentes no ensino remoto e/ou híbrido quanto aos recursos e ferramentas educacionais. Ao todo, foram ofertados seis cursos de capacitações no ano de 2021, de março a outubro, os temas e ferramentas abordadas podem ser conferidos na Figura 1.

Figura 1 - Esquema representativo com os seis cursos do projeto.

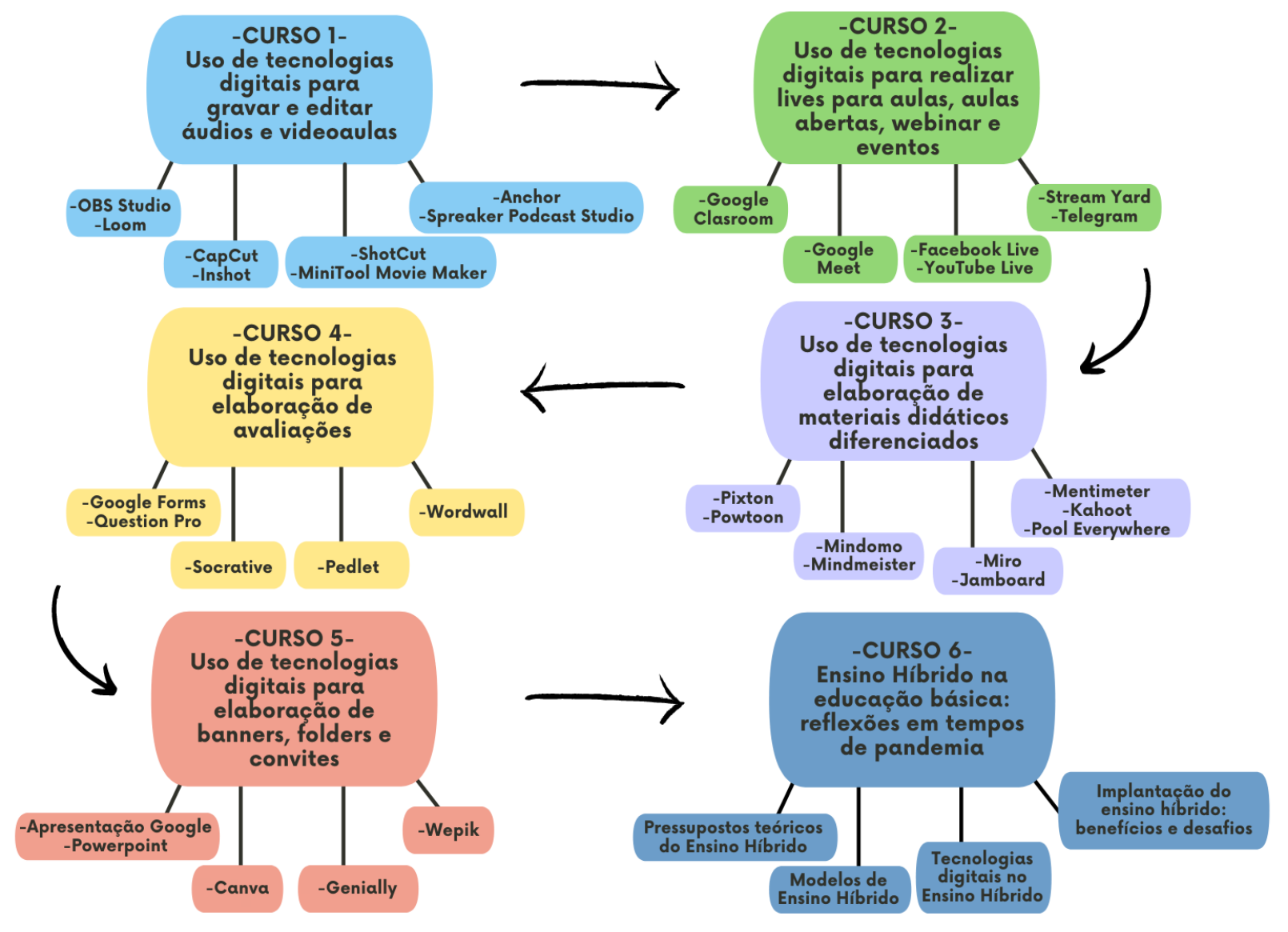

Fonte: Elaborado pelos autores com dados extraídos dos cursos, em 2021.

A divulgação dos cursos ocorreu por meio dos canais de comunicação do 
projeto "Facebook e Instagram - Capacitação digital UFSM". Os cursos contavam com materiais de apoio, como tutoriais em vídeos e em forma de textos, os quais foram disponibilizados no ambiente virtual do Google Classroom, cada ferramenta ou recurso abordado dispunha de um encontro síncrono semanal, com duração de aproximadamente uma hora e meia, pela plataforma YouTube no "Canal Capacitação Digital UFSM". Nesse canal, também eram postados os vídeos tutoriais.

É válido destacar que momentos síncronos possibilitam interações via chat por parte dos professores cursistas, mediadores e instrutores dos cursos. Os vídeos tutoriais e encontros semanais permanecem salvos no canal do projeto, buscando auxiliar aos demais interessados. Em relação à certificação, os participantes deveriam ter presença de no mínimo 50\% nos encontros remotos e preencher o formulário final ${ }^{1}$ do curso em questão, cada curso continha uma carga horária de 60 horas de atividades e inscrições independentes.

\section{RESULTADOS E DISCUSSÃO}

Nesta seção, abordaremos alguns dos resultados obtidos ao longo dos cinco cursos de capacitação, o curso 6 não será considerado, uma vez que o mesmo está ocorrendo. O quadro 1 apresenta algumas características gerais dos cinco cursos.

Quadro 1 - Informações gerais dos cursos.

\begin{tabular}{|c|c|c|c|c|c|}
\hline Características & $\begin{array}{c}\text { Curso 1 } \\
\text { (C1) }\end{array}$ & $\begin{array}{c}\text { Curso 2 } \\
\text { (C2) }\end{array}$ & $\begin{array}{c}\text { Curso 3 } \\
\text { (C3) }\end{array}$ & $\begin{array}{c}\text { Curso 4 } \\
\text { (C4) }\end{array}$ & $\begin{array}{c}\text { Curso 5 } \\
\text { (C5) }\end{array}$ \\
\hline Número de matriculados & 3031 & 380 & 208 & 160 & 84 \\
\hline $\begin{array}{c}\text { Número de concluintes } \\
\text { certificados }\end{array}$ & $385^{*}$ & 127 & 96 & 61 & 27 \\
\hline $\begin{array}{c}\text { Número de respostas no } \\
\text { questionário final }\end{array}$ & 299 & 139 & 109 & 79 & 32 \\
\hline
\end{tabular}

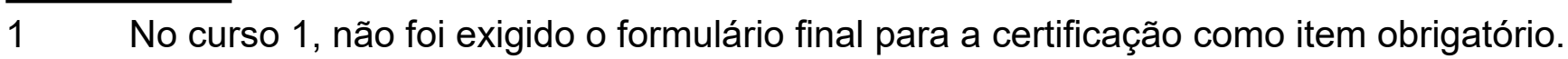




\begin{tabular}{|c|c|c|c|c|c|}
\hline Gênero** Feminino & 267 & 125 & 100 & 69 & 30 \\
\hline Gênero Masculino & 32 & 14 & 9 & 10 & 2 \\
\hline
\end{tabular}

Fonte: Elaborado pelos autores com dados extraídos dos cursos, em 2021.

* Os resultados obtidos no curso 1 são com base em 299 respondentes, uma vez que nesse curso não era obrigatório o preenchimento do questionário final.

**A opção 'outros gêneros' não obteve nenhuma resposta nos cursos.

Destacamos que o número de concluintes e demais dados apresentados diferem, uma vez que os participantes deveriam cumprir os requisitos de no mínimo $50 \%$ de presença e preencher o formulário final (exceção do curso 1). Desta forma, alguns cursistas preencheram o questionário final, porém, não tinham a presença necessária para a certificação. Podemos observar no quadro acima que a representatividade do gênero feminino nos cursos foi conspícua, esse resultado também foi observado em outros cursos de formação continuada descritos pelos pesquisadores Drehmer-Marques e Tolentino-Neto (2021) e Coelho, Monteiro e Luz (2021).

Cabe ressaltar que, para o curso 1, houve um grande número de inscritos, visto que houve um aumento nos dias de inscrição e foi realizada uma divulgação em grande escala, entretanto, alguns participantes inscreveram-se várias vezes. Também ocorreram problemas quanto aos e-mails cadastrados incorretamente e dificuldades de acesso no ambiente do Google Classroom.

No decorrer dos cursos, ocorreram reflexões e avaliação dos proponentes dos cursos em compreender quais são as razões que levam à desistência e a não conclusão do curso. Em razão disso, identificamos a necessidade de mudar o questionário para os próximos cursos que podem ser ofertados, também destacamos a necessidade de adicionar espaços para os cursistas justificarem os motivos que levaram a desistir da formação e, assim, com esse diagnóstico, possamos trabalhar dentro desses dados e construir ações para diminuir a evasão nas próximas ofertas. 
A evasão ocorre em todas as modalidades de ensino presencial, semipresencial e a distância, em instituições públicas e privadas. O cuidado deve ser maior nos cursos a distância, pois "[...] uma dinâmica mediada pelas tecnologias digitais o que fragiliza os vínculos estabelecidos no contato materializado na performance expressiva (entonação da palavra, gesto e corpo) do estudante" (BRANCO; CONTE; HABOWSKI, 2020, p. 2).

Na pesquisa dos autores supracitados foram levantadas diversas causas da evasão, presente por meio do mapeamento de dissertações e teses que investigam o tema evasão EaD, no período 2007 a 2017. As razões podem ser por questões organizacionais, tecnológicas, interacionistas, psicológicas, sociológicas, estratégias de permanência e acompanhamento do indivíduo, como, por exemplo, a insatisfação do curso ou até mesmo a falta de tempo, pois o perfil do nosso público, em sua maioria, são professores ativos e com carga horária de 40 horas de escola. Vale destacar que muitos estão trabalhando na modalidade do ensino remoto e gradativamente retornando ao ensino híbrido e presencial em alguns estados, o que pode acarretar em uma sobrecarga docente.

A fim de delinear o perfil dos participantes dos cinco cursos do projeto, implementamos um questionário final. Tal questionário consistiu, também, em uma estratégia para verificarmos o feedback dos cursos pelo público. Dessa forma, identificamos uma diversidade em relação ao público abrangido pelos cursos.

Em relação à faixa etária dos participantes, nos cinco cursos, a maior representatividade foi entre 30 a 40 anos de idade (C1- 36,12\%, C2- 34,53, C330,27\%, C4-34,14\%, C5- 40,62\%). Destacamos que no C3 a faixa etária de 40 a 50 anos contou com a participação mais expressiva, de 31,19\%. A segunda faixa etária com maior procura nos cursos foi de 40 a 50 anos, seguida da idade de 20 a 30, o público de 50 a 60 anos ou mais de 60 teve menor adesão nos cursos em questão. No trabalho de Drehmer-Marques e Tolentino-Neto (2021), o curso EaD ofertado teve a maior participação de cursistas entre 30 a 40 anos, resultados que se assemelham aos obtidos neste relato. Em relação à jornada de trabalho, 
quando perguntados sobre a carga horária semanal de trabalho docente, os resultados podem ser observados na Tabela 1.

Tabela 1- Jornada de trabalho docente semanal dos cursistas participantes.

Carga horária semanal

Frequência absoluta

$(\mathrm{N}=620)$
Frequência relativa (\%)
Até 10 horas

Até 20 horas

Até 30 horas

Até 40 horas

Até 50 horas

Até 60 horas

Mais de 60 horas

Não atuo
41

142

46

256

42

31

3

$59^{*}$
6,61

22,90

7,42

41,29

6,77

5

0,48

9,51

Fonte: Elaborado pelos autores com dados extraídos dos cursos, em 2021.

*No curso 1 não tinha a opção 'não atuo', após detectarmos a necessidade dessa opção foi acrescida nos demais formulários.

É possível observar que a quantidade mais expressiva dos cursistas participantes apresenta carga horária semanal de trabalho docente de 40 horas, aproximadamente $36,93 \%$ dos professores apresentavam carga horária inferior a 40 horas (até 20 ou até 10). E 12,25 \% dos docentes tinham carga horária superior a 40 horas, 50 ou mais horas. Na pesquisa de Drehmer-Marques e Tolentino-Neto (2021), a maior parte dos cursistas também apresentavam rotina de trabalho docente de 40 horas semanais.

Quanto à formação acadêmica dos participantes, foi possível observar que a maioria possuía formação a nível de especialização, seguido de Ensino Superior completo e mestrado, conforme a figura 2. 
Figura 2 - Formação acadêmica do público dos cinco cursos.

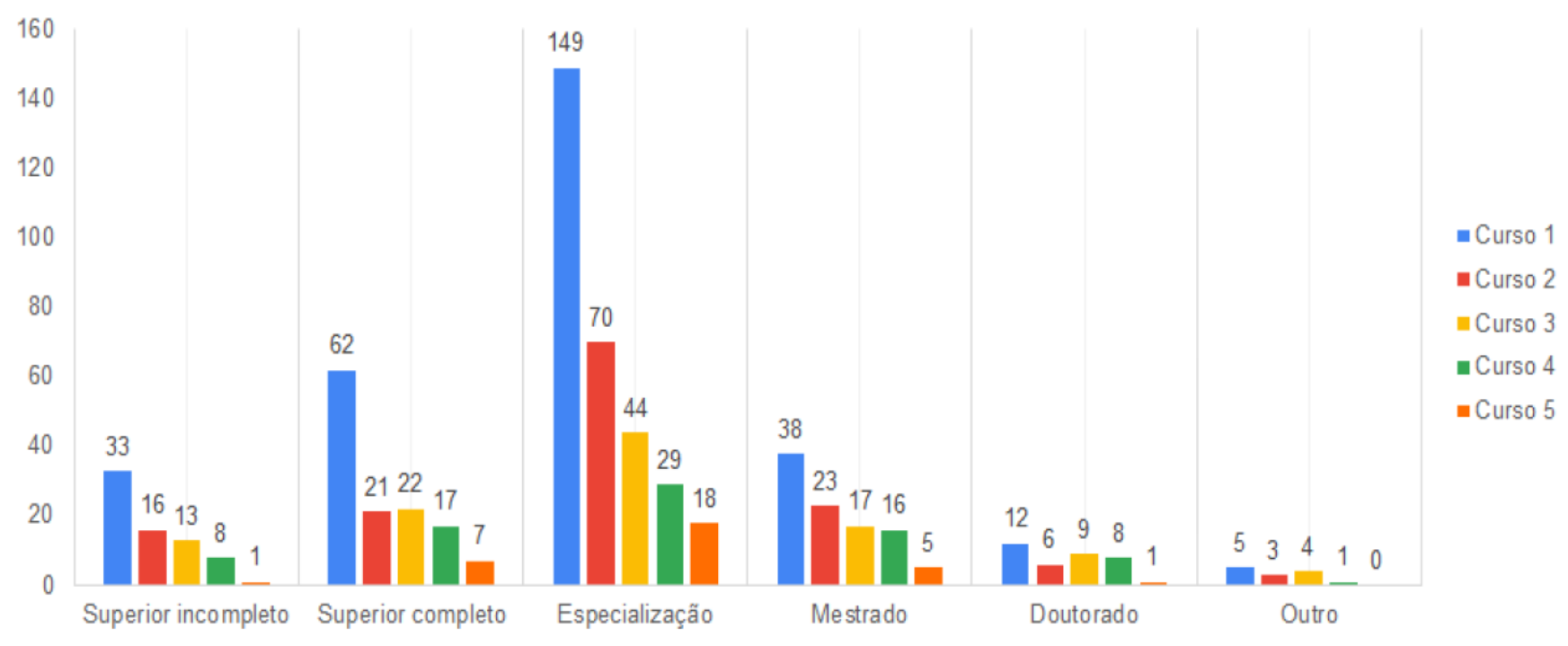

Fonte: Elaborado pelos autores com dados extraídos do questionário final, em 2021.

Os resultados aqui apresentados demonstram que a maioria dos participantes dos cursos possuem especialização em suas áreas de atuação. A aproximação entre universidades e escolas é incentivada visando este intercâmbio de colaboração em mão dupla, essa proximidade pode ocorrer por meio de cursos de pós-graduação, grupos de pesquisas ou por cursos de atualização e demais capacitações.

Segundo Nogueira, Neres e Brito (2016), é necessário que a escola seja um espaço de construção e transformação, buscando parcerias com as universidades e incentivando os professores a darem continuidade à sua formação. No entanto, essa perspectiva ainda não é uma realidade e fatores como alta carga horária de trabalho pode estar relacionada com este distanciamento.

Sobre a atividade atual dos participantes, em maioria eram professores ativos em sala de aula, seguido de estudantes de graduação e pós-graduação, como pode ser observado na figura 3. 
Figura 3 - Atividade atual do público dos cinco cursos.

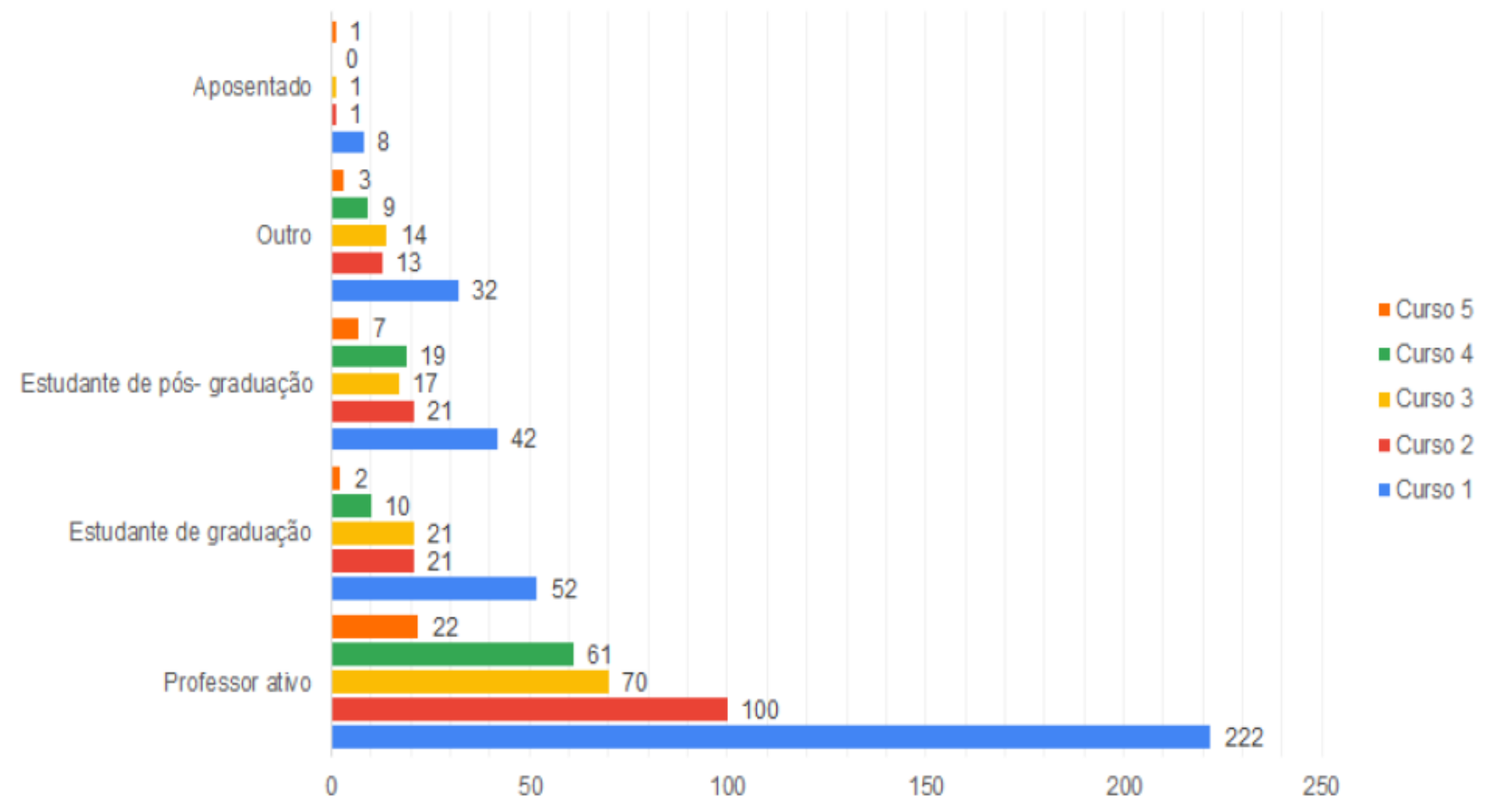

Fonte: Elaborado pelos autores com dados extraídos do questionário final, em 2021.

Salientamos que esses dados, retratados na figura 3, estão de acordo com a finalidade do projeto e dos cursos, que é o de trabalhar diretamente com os professores que estão no ambiente escolar, realizando práticas escolares, enfrentando o desafio do ensino remoto. Desta maneira, percebemos que, pela procura desses profissionais aos cursos, há uma fragilidade em suas formações quanto ao conhecimento e ao domínio das TDIC, fragilidades essas que se manifestaram neste momento pandêmico, quando as aulas passaram de presenciais para remotas, de maneira repentina e sem uma preparação adequada. Leite, Lima e Carvalho (2020, p. 3) colocam que essas questões envolvem:

[...] uma série de elementos que estão em discussão há mais de duas décadas: a inclusão digital e a formação dos professores para o uso das tecnologias digitais, o letramento digital, a apropriação tecnológica, a aquisição de hardware e softwares, o acesso ao uso de tecnologias e até mesmo a qualidade e o custo da conexão.

Frente a isso, estruturamos a capacitação para que além de uma compreensão e entendimento das tecnologias, fosse um espaço de interação, de acolhimento e de fomentar a autoria dos professores frente às suas práticas. 
Quanto ao nível de ensino em que atuam os participantes, observamos que uma grande maioria atua no Ensino Fundamental séries finais, seguido pelos anos iniciais do Ensino Fundamental e Educação Infantil, conforme figura 4.

Figura 4 - Nível de ensino de trabalho do público dos cinco cursos.

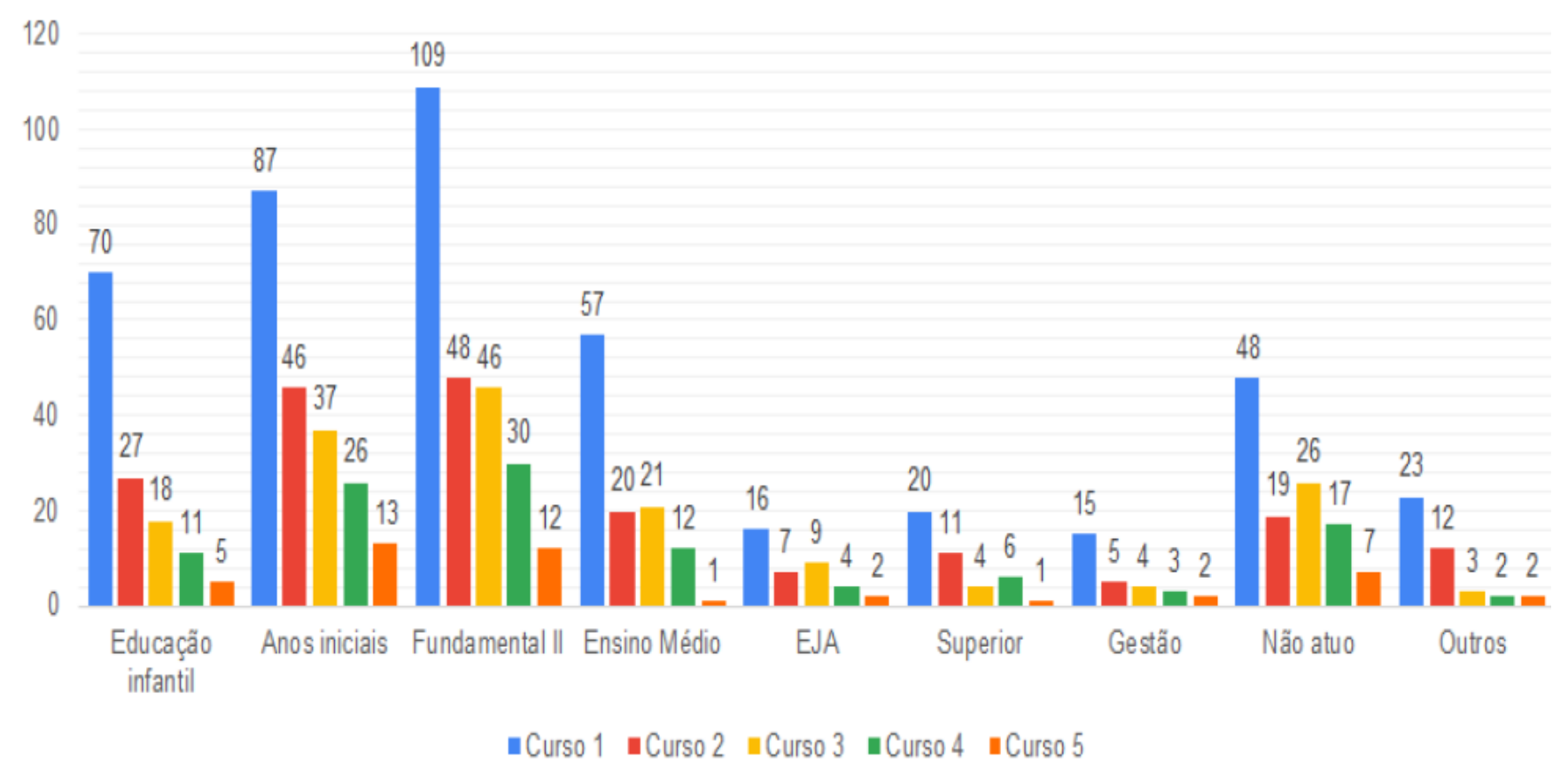

Fonte: Elaborado pelos autores com dados extraídos do questionário final, em 2021.

Como demonstrado na figura 4, a maioria dos participantes dos cursos atuam na Educação Básica, conforme previsto no foco e objetivo dos cursos oferecidos. Evidenciando, assim, a necessidade desses profissionais em se atualizar, buscando conhecimento acerca das ferramentas digitais, para poder suprir as necessidades e cumprir as demandas que o ensino remoto/híbrido impõe. Silva e Silva (2020, p. 51) pontuam que:

Refletir educação em tempos de pandemia nos permite ver o denominado "ensino remoto" seguindo a tendência mundial em meio ao combate ao novo coronavírus, e os desafios da prática docente em contextos vulneráveis onde a formação dos professores e o currículo não atendem as necessidades da escola.

Em relação à localidade dos participantes dos cursos, foi possível observar que em um total de 658 participantes respondentes do questionário final, 551 eram do Rio Grande do Sul, seguido de 21 participantes do Paraná (PR). 
Destacamos a diversidade de estados participantes no curso 1, com um total de 17 estados, que pode estar associada pela intensa divulgação que foi realizada, porém, a partir do curso 2, ocorreu a diminuição da quantidade de estados, uma vez que o foco era para os profissionais da educação do Rio Grande do Sul, em particular os municípios parceiros do "Geoparques" (Silveira Martins, Ivorá, Faxinal do Soturno, Dona Francisca, Nova Palma, Pinhal Grande e São João do Polêsine, Agudo, Itaara, Restinga Seca e Caçapava).

Para estreitar os laços entre os cursistas e os professores instrutores, projetamos um espaço para que os participantes pudessem se apresentar e contar a sua expectativa para o curso. Para isso, na turma do Google Classroom de cada um dos cursos adicionamos o item "Fórum de apresentação". Para preservar a identidade do participante e identificar o curso que participou, utilizamos a numeração aos participantes e aos cursos de 1 a 5 . Assim, apresentamos algumas colocações dos cursistas em relação à expectativa nos cursos (grifos nossos):

Estou com uma expectativa muito boa com o curso, pois tenho muitas dificuldades em realizar vídeos e fazer aulas online e gostaria muito de aprender para me sentir mais segura quando se fala no uso de tecnologias digitais (Participante 1, Curso 1).

Em relação a expectativa com o curso, espero que traga novas visões, aprendizados sobre as tecnologias digitais para nós professores da educação básica que estamos nos atualizando todo dia para dar o melhor aos nossos alunos, afinal ensino remoto é novo e desafiador para nós, desta forma necessitamos das tecnologias digitais a todo momento, para encantar nosso público alvo que é tecnológico (Participante 2, Curso 2).

Busco através destas formações do Curso Digital, continuar aprendendo, em tempos dessa pandemia, precisamos continuar inovando. As ferramentas disponibilizadas nestes tutoriais vem enriquecendo e aprimorando nossas aulas frente às nossas crianças. Aprender novas ferramentas para dar continuidade incentivando a educação de nossas crianças numa sociedade com tantas diferenças (Participante 1, Curso 3).

Ao longo dos últimos meses tenho sido a responsável por publicar nas redes sociais da minha escola material informativa sobre as atividades escolares e utilizo muitos materiais como banners, folders e convites e creio que o aprendizado no curso me ajudará muito a melhorar o engajamento (Participante 3, Curso 5). 
Os comentários acima, acerca das expectativas dos cursos, destacam os desafios e inseguranças frente às tecnologias digitais, à necessidade da inserção das TDIC frente ao ensino remoto/híbrido imposto pelo contexto pandêmico e, também, aos fatores de inovação e entusiasmo frente às diversidades de recursos e ferramentas digitais. Por sua vez, o questionário final oportunizou um feedback dos cursistas, para que pudéssemos avaliar o desenvolvimento dos cursos, a mediação dos conteúdos, as ferramentas trabalhadas e se os mesmos foram satisfatórios para auxiliar nas práticas escolares. Desta forma, para verificarmos esses aspectos, adicionamos duas perguntas para apontar os pontos positivos e os pontos negativos. Em relação aos pontos positivos dos cursos, destacamos alguns relatos (grifos nossos):

Conhecer novos recursos para além dos que eu já conhecia foi muito importante para auxiliar na elaboração de conteúdo. Trabalhando com a Educação Infantil, enviamos muitos vídeos, para que as crianças possam nos ver e ouvir, logo, o curso me ajudou bastante. Os professores demonstraram muito conhecimento sobre os recursos e estavam dispostos a esclarecer dúvidas e nos auxiliares (Participante 1, Curso 1).

[...] disponibilizar os vídeos dos encontros online para assistir posteriormente pois, além de eu não estar disponivel no horário das 18:30 também houve a possibilidade de assistir mais de uma vez o conteúdo. Outra questão foi o de disponibilizarem um prazo para o preenchimento da presença (Participante 3, Curso 2).

Parabenizar a toda a equipe pelas contribuições, conhecimentos e oportunidades que tem proporcionado a nós professores de nos aprimorar, aprender, inovar. Pontualidade, material disponibilizado para estudo, vídeos, tudo muito bem organizado, estruturado, só agradecer a oportunidade de ter esses novos saberes (Participante 4, Curso 2).

Conhecer as ferramentas digitais foi maravilhoso e as interações foram marcantes, me fizeram perder o medo de errar, encarar a tecnologia como meio alcançar resultado positivo! (Participante 3, Curso 3).

Muito interessante as ferramentas apresentadas neste curso, ampliaram as possibilidades para elaboração de avaliações criativas e interativas. Gostei muito da ferramenta Wordwall por oferecer recursos variados e dinâmicos. Com certeza utilizarei as ferramentas abordadas neste curso em minhas futuras práticas pedagógicas. Parabéns a todos envolvidos na realização do curso e agradeço a oportunidade em participar dessa capacitação digital! (Participante 2, Curso 4). 
Observamos nas manifestações dos participantes, que os pontos positivos estiveram relacionados ao processo de conhecer e aprender a utilizar as ferramentas e tecnologias digitais, além de apresentar possibilidades para auxiliar no desenvolvimento das práticas escolares. Nesse sentido, Drehmer-Marques et al. (2021) apontam, a partir dos dados resultantes do projeto "Fluência tecnológica no AVEA Moodle para o planejamento de disciplinas no ensino remoto", a percepção que os professores:

[...] ao interagir com novas tecnologias, iniciaram um processo de incorporação dessas em suas práticas pedagógicas, principalmente, no que tange à dinâmica de comunicação já emergente da cibercultura e da necessidade de qualificar o ensinar e o aprender no ensino remoto (DREHMER-MARQUES et al., p. 101, 2021).

Ainda, nas colocações dos participantes é possível visualizar a importância da organização e a construção de materiais instrucionais que apresentam as ferramentas e tecnologias no sentido de possibilitar que os recursos sejam compreendidos de uma forma simples e, sobretudo, auxiliar os professores no desenvolvimento de atividades. Quanto aos aspectos negativos, destacamos os seguintes relatos:

Tempo do curso, mas admito que é na prática que se descobre as dificuldades de como usar! (Participante 1, Curso 3).

Nem sempre estamos em condições de utilizar os recursos, uma vez que demandam tempo para a familiarização com as ferramentas (Participante 2, Curso 1).

Aspecto Negativo é o tempo que possuo para fazer as Atividades (Participante 3, Curso 4).

Constatamos que os pontos negativos se relacionam em questões referentes ao tempo de curso e à prática com as ferramentas. Entretanto, para adquirir uma fluência em determinada ferramenta, é necessário o manuseio e a exploração da mesma. Desta forma, ressaltamos sobre a relevância das tecnologias digitais como alternativas para desenvolver as atividades escolares na Educação Básica. Contudo, de acordo com Martins (2020), é necessária e urgente a uni- 
versalização do acesso para os alunos, bem como o investimento em educação mediada por tecnologias, com a adoção de uma política pública estratégica para a inclusão digital.

\section{CONCLUSÃO}

O momento pandêmico destacou as fragilidades na formação continuada dos professores, principalmente em relação às faltas de domínio das tecnologias digitais, de acesso à Internet e de eletrônicos. A necessidade de buscar apoio e recursos para desenvolver o ensino remoto foi ao encontro do curso ofertado pela nossa equipe. Surgiu, com isso, a oportunidade de repensar as práticas pedagógicas e as ferramentas que já vinham sendo utilizadas, além da necessidade de incorporar novas ferramentas que pudessem aumentar a dinâmica, a interatividade e a colaboração para atividades educacionais.

A partir dos resultados, destacamos que o projeto voltado para a Educação Básica buscou colaborar na formação dos professores e potencializar as atividades de planejamento, a implementação e a avaliação das atividades no ensino remoto e híbrido. Em relação ao perfil dos participantes dos cinco cursos avaliados, o maior público encontra-se na faixa dos 30 a 40 anos. Com relação à quantidade de carga horária de jornada de trabalho, foi apresentado que mais de $40 \%$ dos participantes trabalham 40 horas semanais e os dados reforçam que o projeto alcançou o objetivo de o público-alvo contemplar os profissionais da Educação Básica atuantes no ensino remoto e híbrido.

Em relação ao primeiro curso, obtivemos maior participação de outros estados, porém, devido à grande demanda de inscritos e a sobrecarga de atividade para a equipe organizadora, restringimos o número de vagas nos demais cursos, em busca de maior aproximação com os participantes e dos parceiros do nosso estado. Sendo assim, primamos por trazer maior qualidade e interações mais efetivas com os participantes, realizando fóruns de apresentação e para esclarecer as dúvidas sobre os tutoriais inseridos na plataforma Google Classroom. 
Com relação ao feedback positivo dos participantes, esse demonstrou o quanto foi potencializado o aprendizado dos professores nas ferramentas digitais e a metodologia de ensino abordada durante o curso. Quanto ao aspecto negativo, destacamos relatos que descrevem problemas relacionados ao tempo do curso, ao tempo de prática com as ferramentas para aprimorar e a falta de tempo para aprender, uma hipótese para tal problemática é devido ao fato de que muitos dos nossos participantes apresentam jornadas de 40 horas semanais.

Ademais, salientamos a importância em oportunizar cursos gratuitos e a distância para auxiliar no aprimoramento de recursos e ferramentas digitais, essa é só uma das ações necessária, uma vez que outras questões precisam ser abordadas de forma conjunta para potencializar a formação dos profissionais da educação e o domínio quanto às competências digitais. Para tanto, é preciso investir em políticas públicas que sejam efetivadas na prática, que atendam a demanda de formação docente.

Por fim, destacamos também maior incentivo e disponibilização de tempo por parte das instituições de ensino destinadas para a realização dos cursos, além de infraestrutura adequada, como computadores, Smartphones e internet de qualidade. Salientamos, ainda, a urgência em pesquisar e investir mais em cursos de formação, de forma que se reduza a evasão dos professores participantes. Essas e inúmeras outras carências precisam ser debatidas e investidas para obtermos modificações significativas na formação continuada de docentes, com maiores qualidades e aproveitamento.

\section{REFERENCIAS}

BRANCO, Lilian Soares Alves; CONTE, Elaine; HABOWSKI, Adilson Cristiano. Evasão na educação a distância: pontos e contrapontos à problemática. Avaliação: Revista da Avaliação da Educação Superior (Campinas), v. 25, p. $132-$ 154, 2020. DOI: https://doi.org/10.1590/S1414-40772020000100008. Acesso em: 24 set. 2021. 
COELHO, Francisco José Figueira; MONTEIRO, Simone; LUZ, Maurício Roberto Motta Pinto da. Formação de Professores em um Curso On-line sobre Drogas: Contribuições da Redução de Danos e da Aprendizagem Colaborativa. EaD em Foco, v. 11, n. 1, e1215, 2021. DOI: https://doi.org/10.18264/eadf.v11i1.1215. Acesso em: 22 set. 2021.

DREHMER-MARQUES, Keiciane Canabarro; TOLENTINO-NETO, Luiz Caldeira Brant de. Formação continuada de professores por meio da Educação a Distância: percepções diante da realidade docente. In: BRANCHER, Vantoir Roberto; DREHMER-MARQUES, Keiciane Canabarro; NONENMACHER, Sandra Elisabet Bazana (org). Formação de professores no Ensino de Ciências. Santo Ângelo: Metrics, 2021, p. 57-78.

DREHMER-MARQUES, Keiciane Canabarro; MARQUES, José Francisco Zavaglia; SCHNEIDER, Daniele da Rocha; ENCARNAÇÃO, Rosiele Oliveira da; ZANCAN, Silvana; MÜLLER, Liziany. Capacitação em Tecnologias Digitais para Educação: uma ação de enfrentamento ao Ensino Remoto Emergencial na UFSM. Revista Novas Tecnologias na Educação (RENOTE), v. 19 № 1, pp. 94 - 104, 2021. DOI: https://doi.org/10.22456/1679-1916.118412. Acesso em: 21 set. 2021.

FERREIRA, Líllian Franciele Silva; SILVA, Vanessa Maria Costa Bezerra; MELO, Keity Elen da Silva; PEIXOTO, Ana Carolina Beltrão. Considerações sobre a formação docente para atuar online nos tempos da pandemia de COVID-19. Rev. Docência Ens. Sup., Belo Horizonte, v. 10, e024761, 2020. DOI: 10.35699/22375864.2020.24761. Disponível em: https://periodicos.ufmg.br/index.php/rdes/article/view/24761/20459. Acesso em: 19 set. 2021.

LEITE, Nahara Morais; LIMA, Elidiene Gomes Oliveira; CARVALHO, Ana Beatriz Gomes. Os professores e o uso de Tecnologias Digitais nas aulas remotas emergenciais, no contexto da pandemia da COVID-19 em Pernambuco. EM TEIA - Revista de Educação Matemática e Tecnológica Iberoamericana - vol. 11 - número 2 - 2020. DOI: https://doi.org/10.36397/emteia.v11i2.248154. Acesso em: 20 set. 2021.

MARTINS, Ronei Ximenes. A Covid-19 e o fim da Educação a Distância: Um ensaio. EmRede, v. 7, n. 1, p. 242-256, jan./jun. 2020.Acesso em: 20 set. 2021.

MODELSKI, Daiane; GIRAFFA, Lúcia MM; CASARTELLI, Alam de Oliveira. Tecnologias digitais, formação docente e práticas pedagógicas. Educação e Pesquisa, v. 45, 2019. DOI: https://doi.org/10.1590/S1678-4634201945180201. Acesso em: 25 set. 2021. 
NOGUEIRA, Eliane Greice Davanço; NERES, Celi Corrêa; BRITO, Vilma Miranda. Mestrado Profissional em educação: a constituição do professor/pesquisador e o retorno para escola. Revista da FAEEBA - Educação e Contemporaneidade, Salvador, v. 25, n. 47, p. 63-75, set./dez. 2016. Disponível em: https://educacao.ufes.br/sites/educacao.ufes.br/files/field/anexo/revistafaeeba_n47-1.pdf. Acesso em: 25 set. 2021.

SCHUARTZ, Antonio Sandro. Tecnologias digitais de informação e comunicação (TDIC) e processo de ensino. R. Katál., Florianópolis, v. 23, n. 3, p. 429-438, set./ dez. 2020. DOI: 0.1590/1982-02592020v23n3p429. Disponível em: https://periodicos.ufsc.br/index.php/katalysis/article/view/1982-02592020v23n3p429/44292. Acesso em: 19 set. 2021.

SENRA, Vanessa Braz Costa; SILVA, Maria Silene. A educação frente à pandemia de COVID - 19: atual conjuntura, limites e consequências. Braz. J. of Develop.,Curitiba, v.6, n.12, p.101771-101785, dec. 2020. DOI: https://doi. org/10.34117/bjdv6n12-608 . Disponível em: https://www.brazilianjournals.com/ index.php/BRJD/article/view/22114/17659. Acesso: 19 set. 2021.

SILVA, Jon Enderson do Nascimento; SILVA, Maria Girleny Roberto. Reflexões e desafios das novas práticas docentes em tempos de pandemia. Org.: Janine Marta Coelho Rodrigues, Priscila Morgana Galdino dos Santos. - João Pessoa: Editora do CCTA, 2020. Disponível em: http://www.ccta.ufpb.br/editoraccta/contents/titulos/educacao/reflexoes-e-desafios-das-novas-praticas-docentes-em-tempos-de-pandemia/reflexoes-e-desafios-das-novas-praticas-docentes-em-tempos-de-pandemia.pdf. Acesso em: 25 set. 2021. 

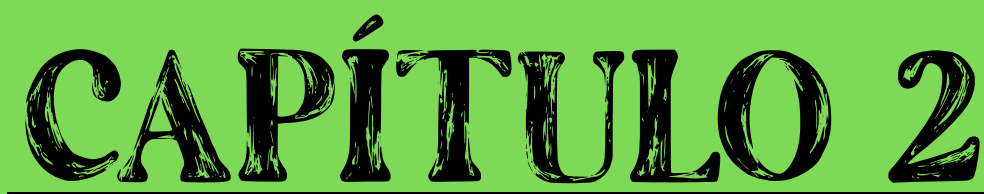

\section{RELATO DE EXPERIÊNCIA NA} RESIDÊNCIA PEDAGÓGICA: UMA PERSPECTIVA DE ENSINO DURANTE A PANDEMIA DO CORONAVÍRUS

Flávio José de Carvalho Sousa Antônio Amadeus Mendes Gonçalves

Haroldo Reis Alves de Macêdo Italo Marcos de Lima 


\section{INTRODUÇÃO}

O Programa de Residência Pedagógica é uma das ações do governo federal que visa garantir a inserção dos estudantes de licenciatura em escolas de educação básica, a partir da segunda metade de seu curso (CAPES, 2018, Online). Esse programa traz a oportunidade do licenciando ter um contato direto, conviver com a realidade de seu curso, enfrentando os desafios e ganhando experiência com os obstáculos postos diante dele. Também é possível propostas de intervenção ligadas ao ensino da disciplina ofertada.

No ensino de física esses desafios estão quase sempre presentes, seja no modo de aprender ou no de ensinar. Segundo Costa e Santos (2017), uns dos problemas mais comuns são: a falta de clareza dos conteúdos explicados e curta duração de aulas. São esses empecilhos que o programa busca desmistificar com a oportunidade de integrar os estudantes desde já em suas futuras profissões.

O Programa foi executado em escolas da rede estadual da cidade de Picos $\mathrm{PI}$, com os bolsistas selecionados no Instituto Federal de Educação, Ciência e Tecnologia do Piauí (IFPI) - Campus Picos. Dentre esses, as vagas foram distribuídas nos cursos de Licenciatura em Física e Licenciatura em Química. Mas a escola tratada aqui é a Unidade Escolar Coelho Rodrigues, onde o residente atuou na sala do $2^{\circ}$ ano do ensino médio com a disciplina de física de forma remota. A aprendizagem de uma disciplina de exatas já é algo um pouco difícil, e fica ainda mais quando se está limitado a não poder ir à escola devido a pandemia do Coronavírus.

Com o ensino cada vez mais debilitado, o Concelho Nacional de Educação (CNE) aprovou a modalidade de ensino remoto até o final do ano de 2021, com a adoção da carga horária a critério de cada instituição ou rede de ensino (SALDAÑA, 2020). E em meio a tais limitações a solução foi ministrar aulas através de aplicativos que permitissem a execução das aulas ao vivo e a organização das mesmas, como exemplo: Google Meet e o Google Classroom respectivamente. 
Esses softwares permitem o compartilhamento de informações e chamadas de vídeo ao vivo com vários alunos. Dessa maneira, surge diversas dúvidas acerca do ensino aprendizagem, e também grandes inovações no ato de recriar o ambiente escolar. O presente trabalho consiste em um relato da experiência, vivida no Programa de Residência Pedagógica do IFPI Campus Picos. Supervisionado e acompanhado por preceptor e coordenador, onde teve o reconhecimento do ambiente, escola/alunos, através de reuniões online e pela leitura dos documentos da escola.

Para elaboração das aulas utilizou-se de materiais didáticos e de apoio, assim como a construção de planos de aula. O livro didático e os slides foram as principais fontes de conteúdo reproduzidos nas aulas. Já como atividade complementar, a promoção de experimentos caseiros foi uma proposta para a integração desse ensino, de forma a conceber os meios para a capacitação e reconhecimento dos fenômenos através de materiais de fácil acesso.

\section{DESENVOLVIMENTO}

\section{AULAS REMOTAS}

As aulas começaram a ser ministradas na Unidade Escolar Coelho Rodrigues no mês de fevereiro de 2021. No entanto, o residente primeiro observou as aulas do preceptor designado, o ambiente virtual, a forma como acontecia e a reação dos alunos nesta modalidade. Também foi orientado como elaborar o plano de atividades para realizar as aulas e um possível projeto de intervenção. Isso tudo se deu pela observação dos pontos positivos e negativos em relação à aprendizagem dos alunos na disciplina de física.

No início foi visto que era preciso um domínio dos softwares para realizar a demanda de conteúdos e para ministrar as aulas ao vivo. Isso também incluiu o desafio da adaptação incumbida aos alunos que, até então tinham que buscar essa alternativa para que não fosse causado muitos danos em seu aprendizado e em sua formação. 
"A Física tem modelos e teorias que explicam grande parte do mundo físico em que vivemos. Biologia, Química, Neurociência e outras áreas científicas usam conceitos, princípios, modelos e teorias derivados da Física" (MOREIRA, 2018, p. 76-77). E tendo essa disciplina tal qual os alunos sentem aversão, por causa de suas equações e aplicações matemáticas, se fez necessário focar de maneira mais geral na abordagem teórica dos conteúdos, feita uma breve revisão das aulas ministradas no ano de 2020. Essa revisão foi para amenizar os impactos causados pelo ensino remoto emergencial, porém, serviu como base para a adaptação do professor e aluno mediante essa nova forma de "sala de aula", seja por causa da experiência nesse formato a distância ou pela dificuldade ao manusear as ferramentas digitais.

\begin{abstract}
Vale lembrar que esse conceito está relacionado diretamente à situação vivenciada pelo mundo atualmente, imposta pela pandemia. Para atender as necessidades educacionais dos alunos, por meio da utilização da educação digital é um grande desafio pois a maioria dos professores não está familiarizado com este tipo de ensino. É necessário que cada contexto seja analisado cuidadosamente, para que nenhum profissional ou aluno seja excluído do processo. Isso inclui a logística (equipamentos e rede de internet) bem como o treinamento de profissionais para que as ferramentas sejam utilizadas de forma correta e proveitosa. (FLAUZINO et al., 2021, p. 3)
\end{abstract}

No entanto, vários fatores contribuíram para uma demora ao iniciar o ensino de forma remota durante o período de pandemia, como o despreparo dos professores, onde segundo Oliveira (2020), quase $90 \%$ dos professores não tinham experiência com aulas remotas antes da pandemia. Outro ponto é o acesso à internet ou dispositivos sem estrutura para garantir uma permanência com as atividades escolares por grande parte dos alunos. Isso afeta diretamente no seu processo de aquisição de conhecimentos, pois segundo Silva (2020), o aluno que passa mais tempo em contato com o computador/internet tem uma predisposição maior em fazer buscas por materiais, os quais fundamentam suas ideias e respostas, ao passo que, o discente que pouco interage nesse meio tem menos facilidade de manuseio e demonstra mais desinteresse. 


\section{ATIVIDADES ONLINE}

A avaliação é a forma de saber se os alunos aprenderam, se a metodologia utilizada tem significância e se os conteúdos foram transmitidos de maneira adequada. Ela é feita de acordo com a necessidade de cada assunto, seja ela teórica ou prática para demonstrar as habilidades desenvolvidas. Contudo, ainda no conceito de avaliação da aprendizagem, Haydt (2006, p. 286) diz que, "[...] a educação é concebida como a vivência de experiências múltiplas e variadas tendo em vista o desenvolvimento motor, cognitivo e social do educando".

Vale ressaltar que, uma melhor compreensão dos fenômenos estudados de maneira teórica na física é indispensável para relacionar as equações, símbolos e aplicações cotidianas. Quando ocorre somente o tradicional: aulas expositivas, exercício e prova, entra-se na "mesmice", um ciclo repetitivo.

O resultado desse ensino é que os alunos, em vez de desenvolverem uma predisposição para aprender Física, como seria esperado para uma aprendizagem significativa, geram uma indisposição tão forte que chegam a dizer, metaforicamente, que "odeiam" a Física (MOREIRA, 2018, p. 73)

Diante disso, a realização das atividades teve que continuar e ser adaptadas ao ensino remoto emergencial juntamente com as aulas online. $E$ assim foi feito essa verificação da aprendizagem, que segundo Haydt (2006), consiste em verificar se eles realmente estão conseguindo absorver os conteúdos e para o professor dar o auxílio necessário para a construção do seu saber.

Logo após o período de observação foi instruído a elaboração do plano de atividades, e posteriormente a atuação do residente como professor/estagiário. Foi esclarecido por meio de reuniões via Google Meet todos os acertos acerca das atividades. Assim como os conteúdos a ser revisados para os alunos, esses que estavam iniciando no $2^{\circ}$ ano, tiveram que rever os assuntos do $1^{\circ}$ ano em física, ou seja, mecânica.

Com as primeiras aulas ministradas o residente pôde perceber uma experiência diferente do imaginado, sendo que esse ensino alternativo veio para 
amenizar a situação educacional no país, no entanto, a falta de contato direto com os alunos e o espaço escolar não substituíram a vivência clássica que é a presença física. Isso trouxe uma sensação de adaptação aos meios que estavam ao alcance. Mas com a devida preocupação em recuperar os possíveis danos causados inicialmente pelo despreparo dos alunos.

As possibilidades avaliativas a princípio pareceram limitadas, porém, aos poucos foi tomando conhecimento de diversas formas que haviam disponíveis online, mas a disciplina de física carece do domínio das leis que regem o mundo e suas aplicações por meio de cálculos, ou seja, era preciso algo tanto objetivo que pudesse ser quantificado como algo qualitativo.

Para a obtenção de dados quantitativos foram utilizadas listas de exercícios, onde visavam verificar o entendimento e reprodução das leis físicas e suas respectivas equações. Já para a avaliação qualitativa, a construção de experimentos ligados aos assuntos repassados em aula era vista como um incentivo a pesquisa, promovendo uma busca mais abrangente dos fenômenos. De acordo com Pirez et al. (2021), sendo feita adequação das ferramentas tecnológicas, é possível prezar por um ensino colaborativo que visa na experimentação não só a comprovação da teoria, mas dialogar com os saberes desenvolvidos mediante a vivência das atividades elaboradas.

\section{RESULTADOS E DISCUSSÃO}

Ficou evidente que o ensino remoto não trouxe um bom rendimento no início, durante as aulas, pois não houve a mesma seriedade e comprometimento que se costuma ter pessoalmente. Ou seja, os alunos participaram menos, não se preocuparam em fazer anotações e, às vezes, tiveram receio de questionar algo. Esses são alguns aspectos notados. Mas é interessante considerar a pouca experiência e autonomia nessa modalidade de aprendizagem, uma vez que os alunos não estão acostumados a esse novo ambiente.

Para ter uma aula mais proveitosa, se fez necessário uma linguagem de fácil compreensão, onde procurou ser desmistificado os conceitos e fórmulas com 
vários exemplos do cotidiano apresentados de modo teórico, visual e auditivo, como: contextualização, vídeos e imagens. O quadro abaixo mostra a abordagem dos conteúdos:

Quadro 1 - Descrição da abordagem dos conteúdos

\begin{tabular}{|c|c|c|}
\hline \multicolumn{2}{|c|}{ Abordagem dos conteúdos } \\
\hline Teórica & Contextualização & $\begin{array}{c}\text { Contexto histórico; } \\
\text { Leis e teorias; } \\
\text { Aplicação ao cotidiano. }\end{array}$ \\
\hline Visual & Imagens, gif, simuladores & Representação de fenômenos. \\
\hline Auditiva & Vídeos e comunicação oral & $\begin{array}{c}\text { Videoconferência; } \\
\text { Videoaulas. }\end{array}$ \\
\hline
\end{tabular}

Fonte: Os Autores

Ademais, a todo momento foi levantado questionamentos pelo residente, fazendo assim com que os alunos pensassem e participassem da aula, buscando compreender os conceitos básicos e viabilizando o intuito de ir além do proposto na aula, ou seja, propostas de temas relevantes ao conteúdo fixo no componente curricular.

Como avaliação de conhecimentos foi utilizado formulários online e experimentos caseiros. Estes formulários foram elaborados com questões elegíveis ao nível da aula e de acordo com as dúvidas explicitadas. Esse método coletou as respostas e mostrou um índice de atrasos muito grande. Já na construção de experimentos, houve uma parcela significativa que atenderam ao esperado, participaram mais e ligaram o trabalho em equipe com a organização e coesão na apresentação das atividades. Mais da metade da turma atrasaram na entrega das atividades objetivas, porém, se empenharam nas atividades práticas. 
Vale ressaltar o papel das atividades experimentais como um meio metodológico de avaliar e ensinar, pois mesmo sendo uma prática que deveria ser comum e respeitada, acaba passando despercebida e não concedida essa experiência para a comunidade discente da maioria das escolas públicas. No entanto, Silva (2017) faz uma análise desse contexto e diz que em contrapartida, o vínculo com determinados assuntos, as possíveis indagações e as trocas de informação são deixadas de lado no que se pode obter com essas atividades quando elas são exercidas, ou seja, demonstradas e colocadas em prática.

Essas atividades até então desenvolvidas, foram de grande colaboração pessoal e profissional para aperfeiçoar as habilidades como futuro professor do bolsista do Programa de Residência Pedagógica, onde trouxe uma realidade diferente da esperada e possibilitou a preparação para as adversidades que possivelmente surgirão na carreira docente. Assim como a pandemia do Coronavírus.

Portanto, as atividades experimentais foram um meio mais descontraído de fazer os alunos interagirem com o professor e entre eles. O objetivo principal era a obtenção do conteúdo por meio de pesquisa ou questionamentos em aula, concretizando a aprendizagem através da busca autônoma de informações e promovendo o interesse pela disciplina.

A atividade girou em torno da obtenção dos materiais, seguido da construção do roteiro experimental - manual de como fazer o experimento, juntamente com os materiais, métodos e explicação científica - e a apresentação através da postagem dos vídeos na plataforma do Google Classroom. Abaixo pode ser observado um dos experimentos feitos pelos alunos. 
Figura 1 - Experimento de densidade do ovo em água

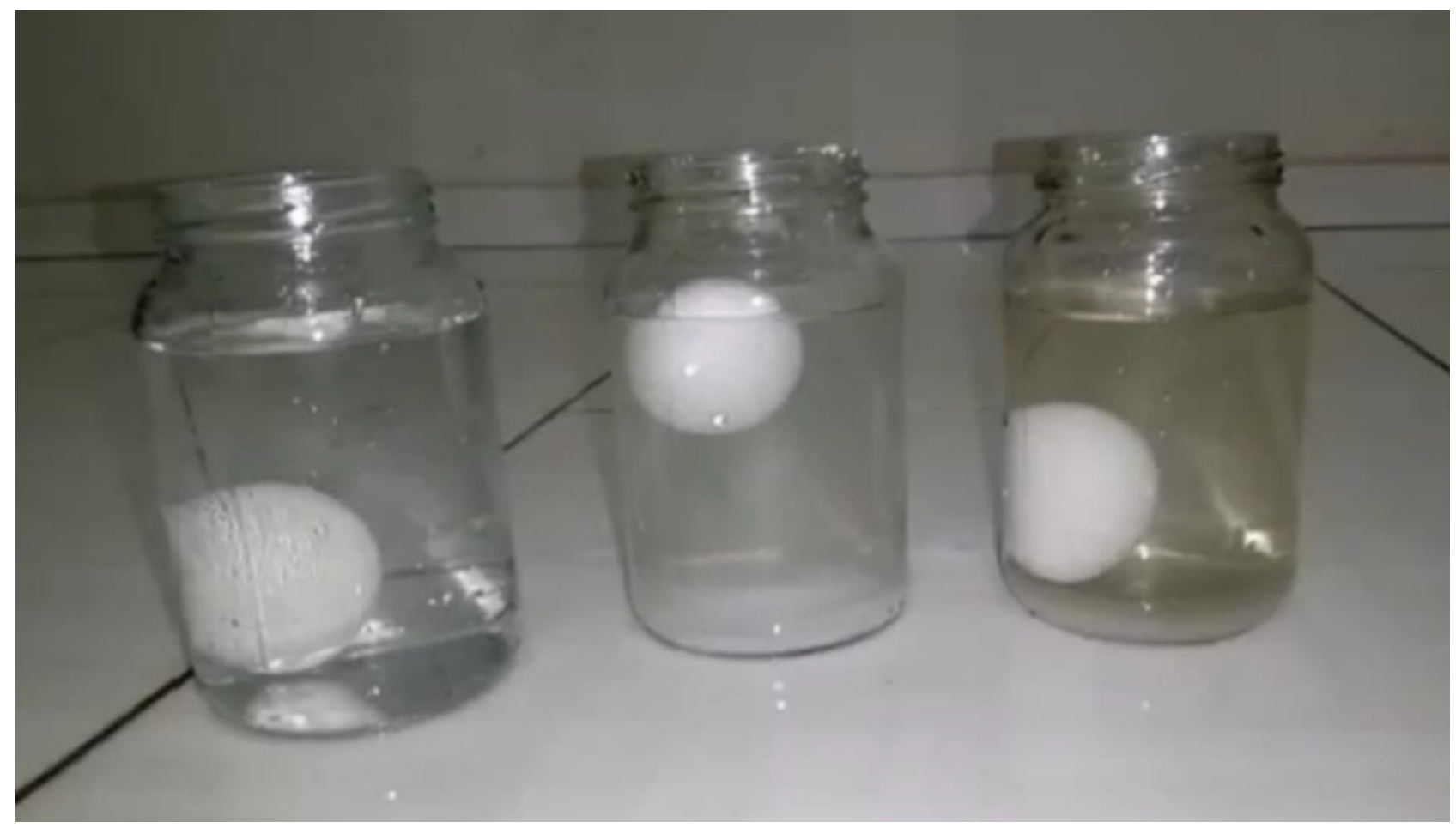

Fonte: Os autores

As principais indagações realizadas foram, "Por que o ovo afunda na água pura?", "Por que o ovo boia na água salgada e na água doce afunda?" e "E se fosse em outro fluido em vez de água?". As perguntas variaram de acordo com o experimento, visto que inicialmente ficou livre a escolha, desde que se referisse ao assunto ministrado.

Essa mistura do conhecimento tradicional mediado principalmente na teoria-cálculo, imposta nas listas de exercícios e dessa vez com a apresentação do fenômeno, serviu como um auxílio no desenvolvimento pessoal e social do aluno, pois visou a abrangência do que deveria ser visto na disciplina e ainda propôs a busca conjunta, atividade em grupo, e individual na aquisição desses saberes além do que está disponível no livro didático.

\section{CONCLUSÃO}

O presente relato de experiência tratou-se do convívio em sala de aula, porém, de maneira remota, e o desenvolvimento de atividades essenciais de um 
professor. Aprender a construir um plano de atividades na prática, dominar as Tecnologias de Informação e Comunicação (TICs), obter metodologias de ensino, se portar diante de uma sala com diversos tipos de alunos desde aqueles mais motivados até os desmotivados e sem orientações.

No entanto, ficou claro que alguns alunos não possuem o hábito de estudar em casa, deixando as atividades acumularem e algumas vezes nem respondendo. E para combater esse desinteresse, foi proposto atividades experimentais em grupos e individuais, no intuito de gerar a participação ativa deles. Contudo, ainda no âmbito de suprir as dificuldades, foi acatado uma comunicação que visava a troca de informações entre o professor e o aluno. Dessa forma, quando se tratou de uma linguagem que remetia e exemplificava os problemas discutidos, eles tendiam a participar mais, esse retorno ocorreu quando foi feito analogia às coisas que os arrodeiam, ou seja, um fenômeno em casa, na rua, na escola, enfim, em uma situação comum na vida de cada estudante. Assim novas dúvidas surgiram, houve mais questionamentos, sugestões, e o que pôde ser considerado como a iniciação do conhecimento científico.

Ensinar e aprender são coisas que devem sempre estar presentes na vida de cada indivíduo. Sendo essa uma das contribuições advindas do Programa de Residência Pedagógica, que proporciona a introdução do graduando a partir da metade do seu curso, possibilitando maior eficácia no exercício de sua função.

\section{REFERENCIAS}

BRASIL. Coronavírus (Covid-19). Ministério da Saúde. Disponível em:< https:// coronavirus.saude.gov.br/sobre-a-doenca>. Acesso em: 20 de mar, 2021.

COSTA, S. Silvana; SANTOS, M. Bianca. Tópicos de Física Estudados no Ensino Médio por Ingressantes No Curso de Licenciatura em Física. Journal of Basic Education, Technical and Technological, Rio Branco - AC, 13 de nov de 2017. South American, p. 202-210. 
FLAUZINO, Vitor Hugo de Paula et al. As dificuldades da educação digital durante a pandemia de COVID-19. In.: Revista Científica Multidisciplinar Núcleo do Conhecimento. 2021. Disponível em:<https://www.nucleodoconhecimento.com. br/saude/educacao-digital>. Acesso em: 29 de set, 2021.

HAYDT, Regina Célia Cazaux. Curso de didática geral. 8. ed. São Paulo: Ática, 2006. 327 p.

MOREIRA, A. Marco. Uma análise crítica do ensino de Física. Estudos Avançados, Rio Grande do Sul, p.73-80, out de 2018.

OLIVEIRA, Elida. Quase 90\% dos professores não tinham experiência com aulas remotas antes da pandemia; $42 \%$ seguem sem treinamento, aponta pesquisa. G1. 2020. Disponível em:<https://g1.globo.com/educacao/noticia/2020/07/08/ quase-90percent-dos-professores-nao-tinham-experiencia-com-aulas-remotas-antes-da-pandemia-42percent-seguem-sem-treinamento-aponta-pesquisa.ghtml>. Acesso em: 29 de set, 2021.

PIREZ, Daiane Rattmann Magalhães. et at. Estado da Questão sobre a Experimentação no Contexto Online: o que Dizem os Eventos da Área do Ensino de Física?. EaD em Foco, v. 11, n. 1, 30 mar. 2021.

PROGRAMA DE RESIDÊNCIA PEDAGÓGICA. Capes, 2018. Disponível em:<https://uab.capes.gov.br/educacao-basica/programa-residencia-pedagogica>. Acesso em: 20 de mar, 2021.

SALDAÑA, Paulo. Conselho de Educação permite aula remota até fim de 2021 no ensino básico e no superior. Folha de São Paulo, 2020. Disponível em: $<$ https://folha.com/wdxnkag6> Acesso em: 29 de set, 2021.

SILVA, J. N. et al. Experimentos de baixo custo aplicados ao ensino de química: contribuição ao processo ensino-aprendizagem. In.: Scientia Plena. 2017. Disponível em:<https://www.scientiaplena.org.br/sp/article/view/3299>. Acesso em: 20 de jul, 2021.

SILVA, Leonilda do Nascimento da. AULAS REMOTAS NO ENSINO DE FÍSICA EM TEMPOS DE ISOLAMENTO SOCIAL. Anais do CIET:EnPED:2020 - (Congresso Internacional de Educação e Tecnologias | Encontro de Pesquisadores em Educação a Distância), São Carlos, ago. 2020. ISSN 2316-8722. Disponível em:<https://cietenped.ufscar.br/submissao/index.php/2020/article/ view/1317>. Acesso em: 14 out. 2021. 


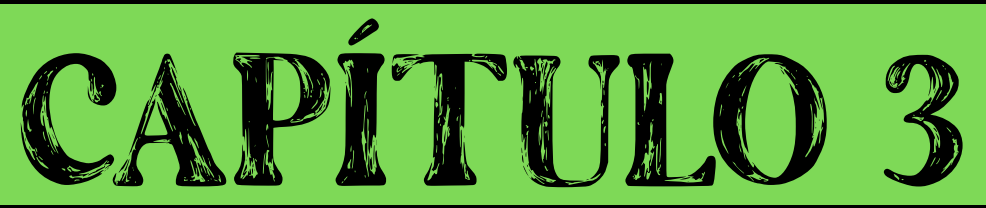

\section{EDUCAÇÃO EM TEMPOS DE PANDEMIA: \\ O USO DAS MÍDIAS NO PROCESSO DE ENSINO}

Joice Vareiro da Costa Brites Priscilla Basmage Lemos Drulis 


\section{INTRODUÇÃO}

Os primeiros vestígios citados por autores da tecnologia na educação foram no século XVII, onde eram utilizados Horn-Book, um material de madeira com letras impressas, utilizados na época para alfabetizar crianças por meio de textos religiosos. Esses textos além de auxiliar na alfabetização, refletiam o momento e influências que a sociedade vivia "o catolicismo". Em 1850 a 1870 eram utilizados o ferule instrumento para auxiliar no apontamento das salas de aula, em 1870 surgiu o Magic Lan Ter, instrumento que se assemelha com o nosso projetor de slides.

Depois desses primeiros instrumentos citados, com a chegada da industrialização a tecnologia avançou muito com a produção em massa de canetas esferográficas, calculadoras, entre outros (BRUZZI,2012) até chegar no uso da tecnologia digital como um dos instrumentos que utilizamos na modernidade, e principalmente no novo contexto social e cultural que vivemos no momento de pandemia.

De acordo com Moran, Masetto e Behrens (2001), durante várias décadas a tecnologia não teve sua devida importância, como ferramenta para tornar o processo de ensino-aprendizagem mais significativo. A razão dessa falta de valorização é a certeza de que a função da escola é disseminar conhecimento aos estudantes por meio dos livros e lousa, bem como avaliá-los com provas e testes, que exigem memorização e que, por inúmeras vezes, podem ser contraditórios ao processo de ensino.

Com início da pandemia em 2019 o mundo teve que se adaptar a novos padrões e organizações, a fim de manter os protocolos de biossegurança, um deles foi o isolamento social, que ocasionou o fechamento de vários estabelecimentos privados e públicos, incluindo as escolas.

Considerando esse contexto, este artigo apresenta os resultados do estudo descritivo que buscou identificar o uso das mídias que têm sido utilizadas pelos professores das escolas municipais da cidade de Campo Grande - MS 
nos processos de ensino e aprendizagem durante o período de pandemia, na interrupção das aulas presenciais. Para tanto, este artigo abordará as plataformas YouTube, Google Meet e WhatsApp.

Nessa vertente, este trabalho consiste em uma pesquisa qualitativa, de caráter documental, desenvolvido por meio de entrevistas semiestruturadas, que tem como objetivo analisar o novo contexto social e cultural, no que refere aos impactos da pandemia no meio escolar, como também as influências dos meios de tecnologia no uso do novo formato educacional.

\section{METODOLOGIA}

Os relatos das aulas e ferramentas utilizadas nesse momento pandêmico foram direcionados para professores que atuam na rede municipal de ensino de Campo Grande - MS, seguindo o foco inicial da pesquisa de como as ferramentas midiáticas foram utilizadas, questionando as suas influências, ou não, diante do ensino remoto. As entrevistas aconteceram de forma remota com questionário semiestruturado e os resultados a seguir são frutos das respostas dos mesmos. Para Triviños (1987):

A entrevista semiestruturada tem como característica questionamentos básicos que são apoiados em teorias e hipóteses que se relacionam ao tema da pesquisa. Os questionamentos dariam frutos a novas hipóteses surgidas a partir das respostas dos informantes. O foco principal seria colocado pelo investigador-entrevistador (TRIVIÑOS,1987, p. 146).

O autor ainda elucida que a entrevista semiestruturada "[...] favorece não só a descrição dos fenômenos sociais, mas também sua explicação e a compreensão de sua totalidade [...]" além de manter a presença consciente e atuante do pesquisador no processo de coleta de informações (TRIVIÑOS, 1987, p. 152).

Essa pesquisa-ação participativa é qualitativa que utilizou como metodologia a coleta de dados por meio das entrevistas semiestruturadas e gravações em áudio. Portanto, o caminho metodológico realizado foi descrever os aplicativos e plataformas utilizados, e também os objetivos que levaram os educadores a 
utilizar as TDIC. Para chegar aos educadores, foram selecionados, professores que estavam ativos na rede municipal de ensino, que utilizavam plataformas e aplicativos enquanto método de ensino.

Este artigo também é de cunho documental, que tem como objetivo realizar uma investigação a respeito do novo contexto social e cultural, no que refere aos impactos da pandemia no meio escolar, como também as influências de meios de tecnologia no uso do novo formato educacional da cidade de Campo Grande - MS. Segundo Severino:

No caso da pesquisa documental, tem-se como fonte documentos no sentido amplo, ou seja, não só de documentos impressos, mas sobretudo de outros tipos de documentos, tais como jornais, foros, filmes, gravações, documentos legais. Nestes casos, os conteúdos dos textos ainda não tiveram nenhum tratamento analítico, são ainda matéria-prima, a partir da qual o pesquisador vai desenvolver sua investigação e análise (SEVERINO, 2007, p. 122).

Por consequência a metodologia utilizada foi baseada em estudos com levantamento de dados e documentos que ampararam a pesquisa, coletando dados por meio de experimentação dos docentes envolvidos no processo de ensino, durante a suspensão das aulas presenciais.

E válido ressaltar, que os professores citados na pesquisa serão identificados como professores A D e M sem seus respectivos nomes, com o intuito de preservar as suas identidades.

\section{A TECNOLOGIA NO MUNDO GLOBALIZADO}

É certo que a humanidade vive em uma constante mudança, uma das mais variantes e frequentes transformações em que o homem cria e recria a todo momento são as tecnologias digitais, que perpassam e rompem barreiras de velocidade e informações. As tecnologias estão em um continuo processo de evolução ocasionando mudanças no cenário cultural, social e metodológico. Para Foucault "o sujeito é aquele que de alguma forma está submetido ao outro (por meio de relações de controle ou dependência) ou então a si mesmo, preso à 
sua própria identidade, mediante a prática do conhecimento de si" (FOUCAULT, 1995, apud FISHER, 2002, p.4).

Adorno em sua celebre obra Dialética do Esclarecimento (1985) nos alerta para falta de autonomia em um mundo globalizado, nos traz o sentido de padronização, e questiona sobre o uso excessivo das tecnologias, que torna o homem um espectador das novas técnicas "contra isso que, nas esferas espirituais, como na arte e, principalmente, no direito, na política e na antropologia, não se avança com o mesmo vigor que nas forças materiais" (ADORNO, 1995b, p.55).

\section{EDUCAÇÃO E PANDEMIA: PROFESSOR, EXPECTADOR OU FORMADOR?}

É assegura por meio da Portaria ${ }^{\circ} 544$, de 16 de junho de 2020 que dispõe sobre a substituição das aulas presenciais por aulas virtuais, durante o período pandêmico do coronavírus - Covid-19, elucidando respectivamente nos Art. $1^{\circ}$, parágrafos II, III, IV e VI, Art. $2^{\circ}$, parágrafos I e II:

Art. $1^{\circ}$ Autorizar, em caráter excepcional, a substituição das disciplinas presenciais, em cursos regularmente autorizados, por atividades letivas que utilizem recursos educacionais digitais, tecnologias de informação e comunicação ou outros meios convencionais, por instituição de educação superior integrante do sistema federal de ensino, de que trata o art. $2^{\circ}$ do Decreto $n^{\circ}$ 9.235, de 15 de dezembro de 2017. [...]

II - Será de responsabilidade das instituições a definição dos componentes curriculares que serão substituídos, a disponibilização de recursos aos alunos que permitam o acompanhamento das atividades letivas ofertadas, bem como a realização de avaliações durante o período da autorização de que trata o caput.

III - No que se refere às práticas profissionais de estágios ou às práticas que exijam laboratórios especializados, a aplicação da substituição de que trata o caput deve obedecer às Diretrizes Nacionais Curriculares aprovadas pelo Conselho Nacional de Educação - CNE, ficando vedada a substituição daqueles cursos que não estejam disciplinados pelo CNE.

$[\ldots]$

IV - A aplicação da substituição de práticas profissionais ou de práticas que exijam laboratórios especializados, de que trata o $\S 3^{\circ}$, deve constar de planos de trabalhos específicos, aprovados, no âmbito institucional, pelos colegiados de cursos e apensados ao projeto pedagógico do curso. 
VI - As instituições deverão comunicar ao Ministério da Educação - MEC a opção pela substituição de atividades letivas, mediante ofício, em até quinze dias após o início destas.

Art. $2^{\circ}$ Alternativamente à autorização de que trata o art. $1^{\circ}$, as instituições de educação superior poderão suspender as atividades acadêmicas presenciais pelo mesmo prazo.

I - As atividades acadêmicas suspensas deverão ser integralmente repostas, para fins de cumprimento da carga horária dos cursos, conforme estabelecido na legislação em vigor.

II - As instituições poderão, ainda, alterar o calendário de férias, desde que cumpram a carga horária dos cursos, consoante estabelecido na legislação em vigor (BRASIL 2020, S/P)

Nesse contexto, com início da pandemia em 2019 o mundo teve que se adaptar aos novos padrões, e organizações, a fim de manter os protocolos de biossegurança, um deles foi o isolamento social, que ocasionou o fechamento de vários estabelecimentos privados e públicos, incluindo as escolas. Assim, as escolas migraram para o ensino remoto. Segundo Moreira e Schlemmer (2020), no ensino remoto:

O ensino presencial físico (mesmos cursos, currículo, metodologias e práticas pedagógicas) é transposto para os meios digitais, em rede. $\mathrm{O}$ processo é centrado no conteúdo, que é ministrado pelo mesmo professor da aula presencial física. Embora haja um distanciamento geográfico, privilegia-se o compartilhamento de um mesmo tempo, ou seja, a aula ocorre num tempo síncrono, seguindo princípios do ensino presencial. $A$ comunicação é predominantemente bidirecional, do tipo um para muitos, no qual o professor protagoniza videoaula ou realiza uma aula expositiva por meio de sistemas de web conferência. Dessa forma, a presença física do professor e do aluno no espaço da sala de aula geográfica são substituídas por uma presença digital numa sala de aula digital. No ensino remoto ou aula remota o foco está nas informações e nas formas de transmissão dessas informações (MOREIRA E SCHLEMMER, 2020, p. 9).

A lousa virou a tela do notebook, o giz o teclado, e os alunos um quadrado com avatares na plataforma do Google Meet. Segundo Pacífico e Gomes (2019):

"A construção da identidade e das identidades alocadas nos avatares; enfim, são inúmeras as reconfigurações estabelecidas. Todavia, a plataforma que serve de alicerce para tantos desdobramentos parece ter, ela própria, transfigurando-se (PACÍFICO; GOMES, 2019, p. 15). 
Nesse momento de isolamento, como profissional da educação também observo os demais profissionais, que além do aumento da demanda de trabalho, tem de lidar com a perda de familiares e colegas de profissão, momento que devido ao isolamento enfrentamos sentimentos de angustia, incapacidade, dor, e até cobranças para sermos mais produtivos em um momento caótico. Além dessas implicações citadas, os professores tiveram grandes desafios como: ensinar de forma remota, bem como aprender a utilizar novos meios de tecnologia para tentar alcançar os alunos. Essa utilização de tecnologias padronizadas nos leva ao conceito de Theodor W. Adorno (1985), que nos alertava sobre a cultura da necessidade do produtivismo em massa.

Os interessados inclinam-se a dar uma explicação tecnológica da indústria cultural. O fato de que milhões de pessoas participam dessa indústria imporia métodos de reprodução que, por sua vez, tornam inevitável a disseminação de bens padronizados para a satisfação de necessidades iguais. O contraste técnico entre poucos centros de produção e uma recepção dispersa condicionaria a organização e o planejamento pela direção. Os padrões teriam resultado originariamente das necessidades dos consumidores: eis por que são aceitos sem resistência. De fato, o que o explica é o círculo da manipulação e da necessidade retroativa, no qual a unidade do sistema se torna cada vez mais coesa. (ADORNO; HORKHEIMER, 1985, p. 100)

Devemos considerar as desigualdades sociais já existentes que se mostraram ainda mais evidentes na pandemia. Com a chegada do ensino remoto segundo dados do IBGE (2018), 20,9\% dos domicílios brasileiros não têm acesso à internet, isso significa cerca de 15 milhões de lares. Em 79,1\% das residências que têm acesso à rede, o celular é o equipamento mais utilizado e encontrado em $99,2 \%$ dos domicílios, porém as famílias tendem a dividir esse aparelho (SOUZA,2020).

Com base nessa realidade, os professores por mais que já utilizavam meios de tecnologia como apoio ao ensino presencial, encontraram dificuldade para se adaptar ao ensino remoto, visto que muitos não têm infraestrutura necessária (INSTITUTO PENÍNSULA, 2020). Além das inúmeras atividades remotas, os docentes tiveram que se organizar em sua vida familiar, uma vez que muitos deles 
são pais de alunos que também estão em aulas remotas. Portanto são várias as implicações e conflitos familiares, nestas novas configurações que se apresentaram.

Do outro lado da tela, os alunos que já vivenciavam uma era digital, foram inseridos mais ainda nesse meio tecnológico. O WhatsApp virou uma sala de aula virtual, os alunos são diariamente bombardeados com vídeos do YouTube, do TikTok, links das aulas, dos jogos, e dos questionários do drive, entre outros. Contudo, esses mecanismos também foram utilizados por professores, a fim de acompanhar as atividades e não perder as interações sociais com esses estudantes.

Diante desse novo contexto escolar, a escola recorreu a aplicativos e plataformas virtuais, na sua grande maioria gratuitos, com o intuito de orientar seus alunos na realização das atividades remotas. Os professores utilizavam esses aplicativos e plataformas que possibilitavam ao docente a realização de seu trabalho mesmo de forma remota.

Nas próximas seções serão expostas duas plataformas: YouTube e Google Meet, e o aplicativo WhatsApp, ambos utilizados em algumas escolas da rede municipal da cidade de Campo Grande - MS, como também relatos de três professoras que utilizaram essas plataformas no ensino remoto.

\section{YOUTUBE}

É uma plataforma de compartilhamento de vídeos, em que sua missão é de dar voz a todas as comunidades, baseando-se nos direitos de liberdade e expressão, onde todos devem ter acesso livre e fácil às informações, além de ter grande influência na educação. A plataforma possui uma interface chamativa, com uma série de vídeos, onde qualquer usuário pode ter acesso, já que a mesma é gratuita e funciona de maneira síncrona ${ }^{2}$ e assíncrona ${ }^{3}$.

2 é um adjetivo que se aplica a algo que acontece simultaneamente.

3 que não ocorre nem se efetiva ao mesmo tempo. 
Figura 1 - Plataforma YouTube

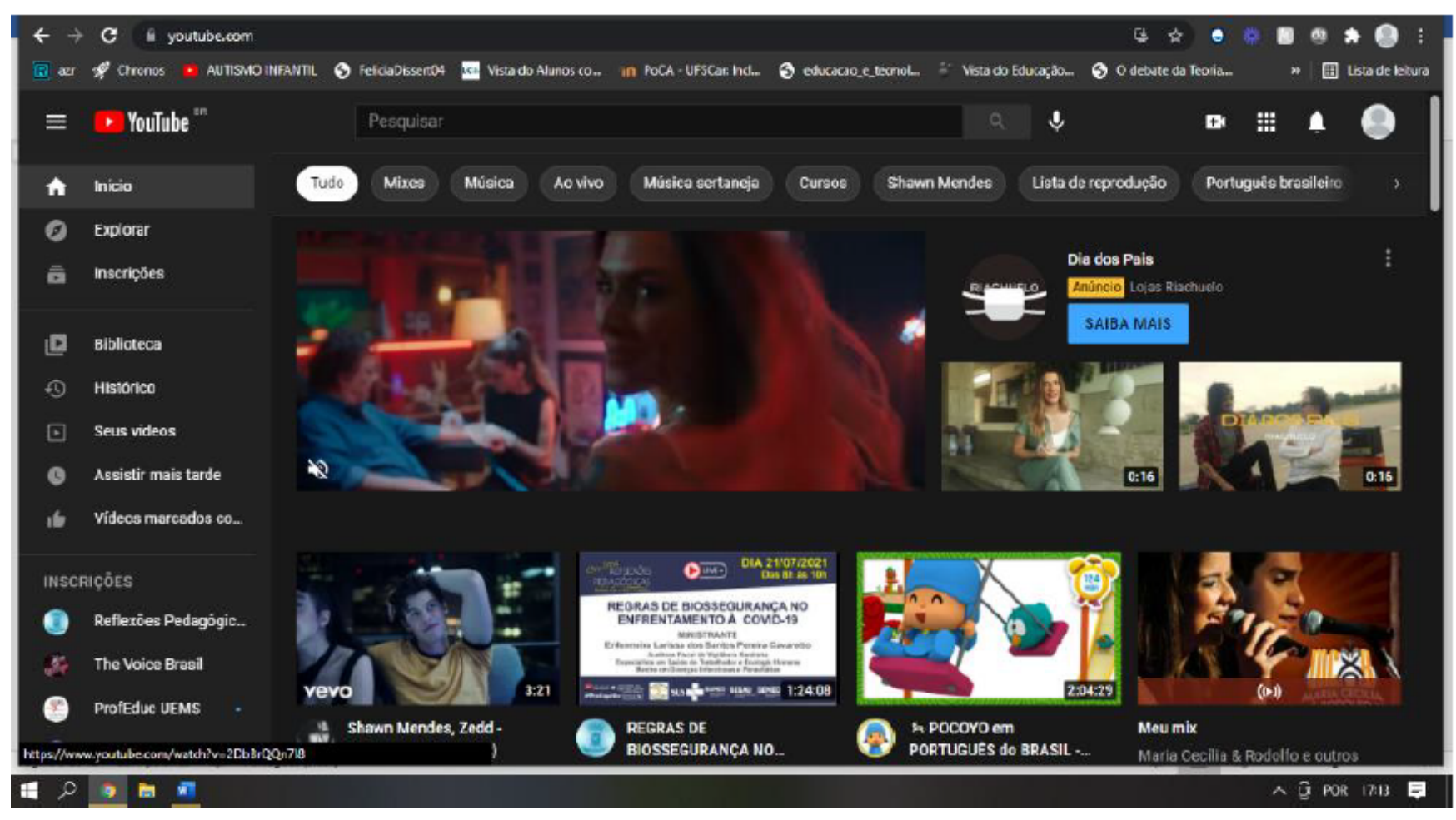

Fonte:https://www.youtube.com/(2021)

Durante as entrevistas foi possível constatar que a forma mais utilizada pelos professores é de forma assíncrona, devido seu fácil compartilhamento, e por não ter a necessidade da gravação simultânea das aulas ministradas pelos professores, considerando-se que a internet em muitos lugares do país não garante um acesso ideal a seus usuários (KENSKI, 2013).

O entrevistado A descreve algumas barreiras no que tange o uso de vídeos na educação.

Gravar vídeos não dá, eu utilizo os vídeos já disponíveis no YouTube, tem alguns professores que já produzem esse material na plataforma, não é fácil gravar e postar um vídeo utilizando $3 \mathrm{G}$, eu por exemplo sei de colegas que gastaram com materiais de iluminação, mas mesmo assim os vídeos não ficaram bons, devido à internet, precisa além de muito domínio tecnológico, um computador bom e paciência porque a internet em algumas horas do dia que não funciona bem. Você perde tempo do seu planejamento tentando criar vídeos, e não consegue produzir um material bom que os alunos já estão acostumados a ver (PROFESSORAA).

Os vídeos mencionados pelo entrevistado eram enviados por meio de links copiados da própria plataforma YouTube, onde os professores YouTubers criam 
seus avatares na interface para produzir conteúdo, a fim de auxiliar o público que busca estudar tal conteúdo. É uma plataforma que não necessita baixar o aplicativo no celular, porém utilizada de forma assíncrona, não permite o diálogo entre professor e aluno, ou seja, o aluno não pode tirar dúvidas em vídeos já adicionados à plataforma. "O desenvolvimento tecnológico culmina no empobrecimento da experiência humana e na alienação da linguagem" (PACÍFICO,2012).

No que se refere ao uso dessa plataforma, na entrevista foi perguntado se achavam que de alguma forma esse material teria influência na aprendizagem dos seus alunos. O entrevistado M, que atua desde 2007 na REME, faz a ressalva do uso indevido desse material.

Os alunos já utilizam muito YouTube, antes mesmo da pandemia, eu tiro pelos meus filhos que sempre gostaram de assistir youtuberes direto do celular, eu evito enviar tantos links nos grupos de WhatsApp, porque sei que dali eles podem clicar em outros vídeos que não tem nada a ver com o conteúdo da aula, falo isso como mãe de aluno, eu não estou lá para ver, e não sei se os pais estão verificando os vídeos que as crianças estão assistindo (ENTREVISTADO M).

O entrevistado A traz outras perceptivas sobre o uso da plataforma:

Eu utilizo sempre os vídeos do YouTube, encaminho o link pelo WhatsApp através dos grupos de sala, meus alunos sempre interagem e falam o que acharam do vídeo, acredito que usado de maneira correta, sempre orientando os alunos sobre o uso, não tem problema, é importante que esse ano tenha uma orientação dos pais, principalmente agora no ensino remoto. (ENTREVISTADO A).

Por meio dos dispositivos móveis, o acesso se dá em qualquer lugar e hora, é nessa perspectiva que caminha a evolução, a aquisição de conhecimento acontece muitas vezes pelo celular, que são utilizados em múltiplas funções pelo usuário (SANTAELLA 2010) e nesse novo contexto escolar o celular se tornou o objeto principal para acesso às aulas, bem como um instrumento pedagógico para os professores.

\section{PLATAFORMA GOOGLE MEET}

Quando criado o Google Meet foi pensado para a criação de vídeo chamadas, a fim de facilitar a participação de trabalhadores em reuniões de forma remo- 
ta. É uma plataforma de fácil visualização de seus ícones, facilitando o manuseio para os usuários. Para ingressar nas vídeos chamadas ou criá-las, deve-se abrir uma conta no Google. Ressalta-se que a plataforma permite reuniões com até 100 usuários. (SUPPORT GOOGLE MEET).

Figura 2 - Paisagem

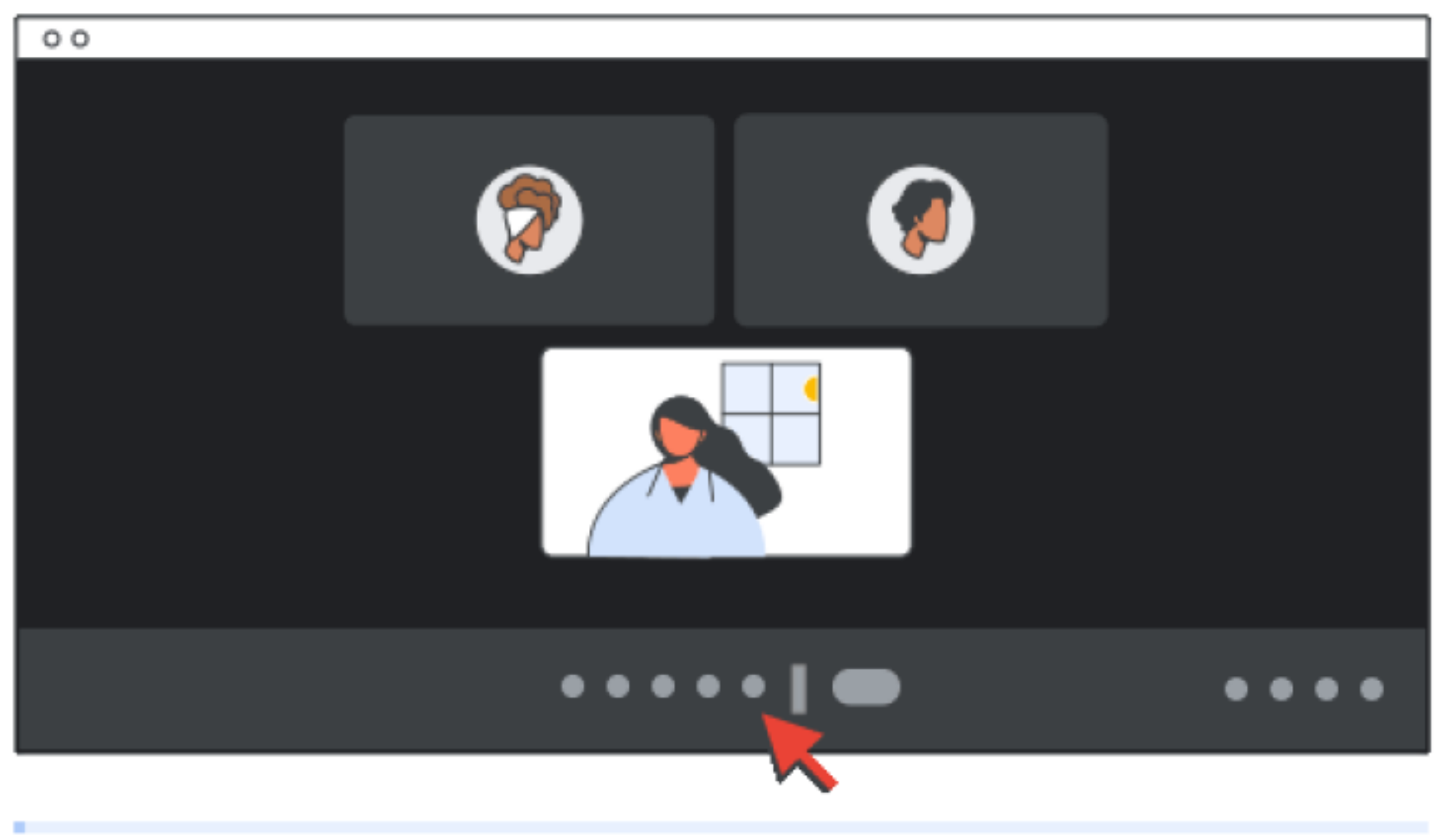

Fonte: Support Google Meet (2021)

De acordo com as respostas dos entrevistados, ambos avaliaram a plataforma como uma das mais utilizadas. Quando o entrevistado A foi questionado, ele informou que tem apreço pela utilização dessa plataforma, pelo fato da aproximação entre professor e aluno. No que se refere a esse uso o entrevistado $A$ nos traz seu relato:

O google meet me possibilitou conhecer alguns alunos do $4^{\circ}$ ano. Através das chamadas de vídeo, consegui aplicar algumas atividades, observar o nível de leitura, a dificuldade em questões de matemática. Até orientei alguns pais sobre livros e metodologias de leitura para facilitar o ensino (ENTREVISTADO A).

A utilização dos recursos da plataforma, assim como a possibilidade de compartilhamento de tela, possibilita o docente criar métodos de orientação com 
Power Point, vídeos, jogos, entre outros. Outro meio de comunicação que a ferramenta apresenta é o bate-papo pelo chat, onde os alunos podem se comunicar com a turma. Devemos considerar que com o avanço da tecnologia e várias interfaces nos conduziram a outro cenário: o desvirtuamento do processo formativo, no que se refere ao abandono das experiências e vivências. (PACÍFICO,2012)

Essa plataforma permite algumas intervenções pedagógicas, mas, não garante o sucesso no processo de ensino-aprendizagem, como podemos observar no relato do entrevistado $A$ :

Eu gosto porque posso vê-los, porém, não sei se realmente estão fazendo as atividades de maneira correta, eu não tenho acesso ao material naquele momento, em algumas vezes fico na dúvida se estão compreendo o conteúdo ou escrevendo de forma correta. (PROFESSORA D)

No depoimento da professora devemos considerar as dificuldades desse novo método de ensino, que segundo Brito e Purificação (1997, p. 4): "não garante a eficiência do processo ensino-aprendizagem", mas deve ser "uma alavanca de inovações pedagógicas a serviço da construção de saberes", conforme dispõe Alava (2002, p. 14).

\section{APLICATIVO WHATSAPP}

O aplicativo segundo seu Software ${ }^{4}$, é uma multiplataforma, ou seja, você pode trocar mensagens, fazer vídeos chamadas e também ligações. Na pandemia o aplicativo foi utilizado em algumas escolas para orientações de atividades, e até mesmo para transmitir recados. Foi muito utilizado porque já faz parte do uso cultural da população.

No depoimento do entrevistado $D$, podemos verificar seu uso por meio do aplicativo:

Antes da pandemia já utilizava esse aplicativo, acredito que muitos dos meus alunos também tinham, porque alguns já tem celular, eu mandava links dos vídeos chamados do Google Meet e vídeos da internet. Os informativos e orientações das aulas também eram postados nos grupos

4 Programa, rotina ou conjunto de instruções que controlam o funcionamento de um computador; aplicativo; suporte lógico. 
da turma no WhatsApp. (ENTREVISTADO D).

No depoimento acima observa-se que muitos alunos já tem seu próprio celular, pois já tem acesso a vários aplicativos e redes sociais, onde a escola se tornou mais um meio para utilizarem os meios tecnológicos. Nesse mesmo pensamento para GraemL; Volpi; GraemL (2004).

Todos esses atrativos estão levando as pessoas há passar mais tempo na frente do computador. Isto acontece inclusive com as crianças, que buscam na Internet diversão e informação. Está nova maneira de viver exige reflexão e discussão quanto à socialização das pessoas. Muitos autores criticam o uso excessivo do computador, alegando que este comportamento pode causar isolamento social. Assim, ocupa o tempo antes destinado a outras formas de lazer e ao convívio social. Considerando estes aspectos, observa-se que a Internet está trazendo, junto com ela, mudanças significativas no comportamento social e individual das pessoas (GRAEML; VOLPI; GRAEML, 2004, p.2).

Com a chegada da industrialização a tecnologia avançou muito com a produção em massa de meios digitais para o ensino. Durante a pandemia foi possível perceber que o mundo passou por adaptações aos novos padrões, a fim de organizar-se e manter os protocolos de biossegurança, onde foi necessário o isolamento social, e a tecnologia virou o maior meio de comunicação e socialização nesse enredo.

\section{CONCLUSÃO}

As tecnologias se mostraram mais presentes no nesse momento pandêmico, teve um outro meio de relacionamento entre professor e aluno. As salas de aula se tornaram um novo ambiente virtual, uma realidade que trazem vários benefícios, porém também podem trazer consequências negativas, como uso excessivo delas.

Por fim, devemos garantir enquanto professores o uso orientado desses meios, garantindo a experiência desses alunos, não tirando a essência da interação social e relação com seus pares, visto que a principal fase do desenvolvimento se dá na infância. Não devemos delimitar a telas, e sim criar novos espaços para conviver criando novas experiências reais. 


\section{REFERENCIAS}

ALAVA, Seraphin. Ciberespaço e formações abertas: rumo à novas práticas profissionais. Porto Alegre: Artmed, 2002.

ADORNO, T. W. Educação e emancipação. 3. ed. Trad. Wolfgang Leo Maar. São Paulo: Paz e Terra, 1995a.

ADORNO, T. W. O fetichismo na música e a Regressão da Audição. In: Textos escolhidos. SP: Abril Cultural, 1999. Coleção: Os pensadores.

ADORNO, T. W. Palavras e sinais: modelos críticos 2. Tradução de Maria Helena Ruschel. Petrópolis, Vozes, 1995b.

BRASIL. Medida Provisória $n^{\circ} 934$, de $1^{\circ}$ de abril de 2020. Diário Oficial da União, 2020. Disponível em: https://www.in.gov.br/en/web/dou/-/medida-provisoria-n-934-de-1-de-abril-de-2020-250710591. Acesso em: 15/10/2021.

BRASIL. Portaria n ${ }^{\circ}$ 544, de 16 de junho de 2020. Diário Oficial da União, 2020. Disponível em: https://www.in.gov.br/en/web/dou/-/portaria-n-544-de-16-de-junho-de-2020-261924872. Acesso em:15/10/2021.

BRITO, G.S.; PURIFICAÇÃO, I. Educação e novas tecnologias: um repensar. Curitiba: IBPEX, 2006.

BRUZZI, D. Uso da tecnologia na educação, da história à realidade atual UFC 2012.

FISCHER, Rosa Maria, Mudança e Transformação Organizacional, In: FLEURY, M., (org.), As pessoas na organização. São Paulo: Editora Gente, 2002.

GRAEML, K. S.; VOLPI, J. H. e GRAEML, A. R. "O impacto do uso (excessivo) da Internet no comportamento social das pessoas ". Revista Psicologia Corporal(José Henrique Volpi e Sandra Mara Volpi, Orgs.). Vol. 5, 2004.

MARX, K. O capital. Lisboa: Editorial Progresso, 1996. v. I, livro primeiro.

MORAN, J. M.; MASETTO, M. T.; BEHRENS, M. A. Novas tecnologias e mediação pedagógica. São Paulo: Papirus, 2001. 
MOREIRA,J.A.,SCHLEMMER,E. Por um novo conceito e paradigma de educação digital onlife. Revista UFG, 2020, V.20, 63438, p. 2-35. Goiânia: UFG, 2020.

PACÍFICO, M; GOMES, L. R. O espetáculo de si: uma proposição sobre a atualidade da sociedade do espetáculo. Comunicações. Piracicaba, v. 26, n. 1, p. 165-179, 2019.

PACÍFICO, M. Infância, experiência e linguagem em Walter Benjamin: a indústria cultural e as implicações pedagógicas do empobrecimento da experiência formativa. São Carlos: UFSCar, 2012. $125 \mathrm{f}$.

PENÍNSULA, I. Sentimento e percepção dos professores brasileiros nos diferentes estágios do Coronavírus no Brasil. 2020. Disponível em: <https:// www.institutopeninsula.org.br/> Acesso em: 15 outubro 2021.

QUÉAU, P. O tempo do virtual. In: PARENTE, André (org.). Imagem Máquina: a era das tecnologias do virtual. 3 ed. São Paulo: Ed. 34, 2001. p. 91-99.

SANTAELLA, L. A aprendizagem ubíqua substitui a educação formal? Revista de computação e tecnologia da PUC-SP, São Paulo, v. 2, n. 1, p. 17-22, jan. 2010. Disponível em: https://revistas.pucsp.br/index.php/ReCET/article/view/3852. Acesso em: 15 outubro 2021.

SEVERINO, A. J. Metodologia do Trabalho Científico. São Paulo: Cortez, 2007.

SOUZA, E. P de. Educação em tempos de pandemia: desafios e possibilidades. Caderno de ciências sociais aplicadas. Universidade Federal da Bahia, 2020.

TRIVIÑOS, A. N. S. Introdução à pesquisa em ciências sociais: a pesquisa qualitativa em educação. São Paulo: Atlas, 1987.

TÜRCKE, C. Sociedade excitada: filosofia da sensação. Tradução Antonio A.S. Zuin, Fabio A. Durão, Francisco F. Fontanella, Mario Frungillo. Campinas, SP: Unicamp, 2010. 


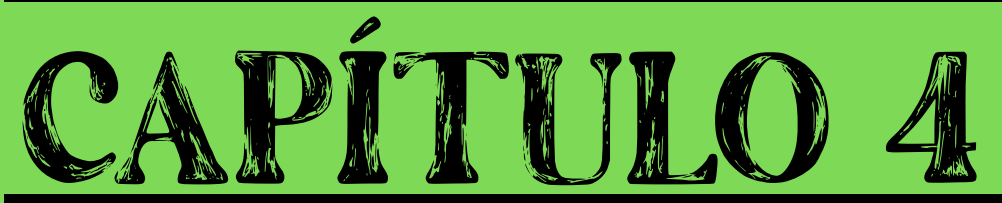

\section{ENSINO REMOTO NA UFSM:} OPINIÕES DOS ALUNOS INGRESSANTES SOBRE O REDE - REGIME DE EXERCÍCIOS DOMICILIARES ESPECIAIS

Sidnei Renato Silveira Antônio Rodrigo Delepiane de Vit 


\section{INTRODUÇÃO}

Este capítulo apresenta as opiniões dos alunos acerca da modalidade de ensino remoto na UFSM (Universidade Federal de Santa Maria), denominada REDE (Regime de Exercícios Domiciliares Especiais), adotada durante o período de isolamento social devido à pandemia de COVID-19 (UFSM, 2020; UFSM, 2021).

Os estudantes participaram por meio de um instrumento disponibilizado no Ambiente Virtual de Aprendizagem Moodle. O instrumento contém doze perguntas e foi construído no Google Forms. Os participantes são ingressantes do Curso de Bacharelado em Sistemas de Informação da UFSM Campus Frederico Westphalen/RS e cursaram, em 2021/1, a disciplina SIN1046 - Sistemas de Informação.

A disciplina, seguindo o REDE/UFSM, foi ministrada de forma remota, utilizando-se o AVA Moodle, diferentes materiais didáticos-digitais elaborados pelos professores, fóruns de discussão, construção de mapas mentais, utilização de softwares específicos, além de vídeoaulas realizadas no formato de lives (on line) e gravadas antecipadamente, todas disponibilizadas nos canais dos professores no YouTube. A metodologia de ensino empregada foi a Sala de Aula Invertida (BERGMANN, 2018; BERGMANN; SAMS, 2018).

Neste contexto, este capítulo apresenta um relato das experiências realizadas na modalidade de ensino remoto, na disciplina SIN1046 Sistemas de Informação, durante o primeiro semestre letivo de 2021. Além do relato de experiências são apresentadas, também, as opiniões dos alunos sobre a condução dos processos de ensino e de aprendizagem.

\section{SALA DE AULA INVERTIDA}

A Sala de Aula Invertida, ou Flipped Classroom, é uma metodologia ativa de aprendizagem, que busca possibilitar a autonomia dos estudantes, como sujeitos ativos na construção do conhecimento. Além disso, esta metodologia também 
privilegia os momentos de interação, preferencialmente presenciais, para que professores e estudantes possam compartilhar o conhecimento (BERGMANN, 2018; PAVANELO; LIMA, 2017; TUCKER, 2012). Entretanto, apesar da metodologia privilegiar os momentos presenciais, ela pode ser aplicada, também, no ensino remoto, híbrido e na EaD (Educação a Distância). A interação, em cursos ministrados na modalidade de ensino remoto, por exemplo, pode ser estimulada por meio de ferramentas síncronas e assíncronas, tais como discussões realizadas por meio de fóruns, bate-papo (chat), videoaulas online (lives), entre outras.

Segundo a metodologia da Sala de Aula Invertida, os alunos devem estudar os conteúdos em casa e irem à escola ou universidade para encontrar professores e colegas para esclarecer dúvidas, fazer exercícios, trabalhos em grupo e avaliações. Os encontros presenciais podem ser utilizados, também, para fortalecer a relação entre os estudantes e entre os estudantes e o professor. Nesta proposta, a "lição de casa" é feita em sala de aula e a aula é "dada em casa". Esta metodologia tem sido empregada em inúmeras universidades, tais como Harvard, Yale e Stanford, entre outras (PAVANELO; LIMA, 2017; SILVEIRA; BERTOLINI; PARREIRA, 2020).

Esta metodologia coloca o aprendente como protagonista, ou seja, como sujeito ativo no processo de construção do conhecimento. Esta não é uma ideia nova, pois a participação mais ativa dos alunos nos processos de ensino e de aprendizagem faz parte da teoria construtivista de Piaget: o aluno como sujeito na construção do conhecimento (FRANCO, 2004). Para tanto, o aprendiz precisa ter acesso prévio ao conteúdo, por meio de diferentes materiais didáticos, tais como vídeoaulas por exemplo. Estes materiais didáticos podem ser disponibilizados por meio de AVAs (Ambientes Virtuais de Aprendizagem), que facilitam o acesso dos alunos por meio da Internet. Além das videoaulas, podem ser utilizados outros materiais didáticos-digitais, tais como simulações, jogos educacionais digitais, quizzes, entre outros. Estes materiais são denominados OAs (Objetos de Aprendizagem) (PARREIRA; FALKEMBACH; SILVEIRA, 2018). 


\section{RESULTADOS E DISCUSSÃO}

O relato de experiências aqui apresentado compreende as atividades desenvolvidas na disciplina SIN1046 Sistemas de Informação, ofertada para os ingressantes do Curso de Bacharelado em Sistemas de Informação da UFSM/FW, no primeiro semestre letivo de 2021. Para dar conta da modalidade de ensino remoto, por meio do REDE/UFSM, os docentes utilizaram o AVA Moodle, além da realização de videoaulas gravadas e on line (lives), por meio da ferramenta Google Meet. As videoaulas foram disponibilizadas, também, por meio de um canal no YouTube. A Tabela 1 apresenta os dados quantitativos referentes aos recursos empregados na referida disciplina.

Tabela 1 - Quantidade de Recursos Empregados na Disciplina SIN1046

\begin{tabular}{|c|c|}
\hline Recursos & Quantidade \\
\hline $\begin{array}{c}\text { Materiais didáticos - Slides com o conteúdo } \\
\text { das aulas expositivas }\end{array}$ & 08 \\
\hline Exercícios & 04 \\
\hline $\begin{array}{c}\text { Videoaulas (gravações utilizando o Microsoft } \\
\text { PowerPoint e/ou o Google Meet) }\end{array}$ & 12 \\
\hline Videoaulas (lives utilizando o Google Meet) & 02 \\
\hline Fóruns de Discussão & 05 \\
\hline Atividades de Pesquisa/Elaboração de Projetos & 02 \\
\hline Exercícios Práticos utilizando softwares & 02 \\
\hline Construção de Mapas Mentais & 01 \\
\hline Tutoriais & 01 \\
\hline TOTAL & 37 \\
\hline
\end{tabular}

Fonte: Os autores, 2021.

A cada aula, disponibilizada no Moodle, os docentes incluíram uma explicação sobre o que seria estudado e quais atividades deveriam ser realizadas, além de links para acesso às videoaulas e materiais de apoio. Os materiais de apoio compreendiam slides desenvolvidos pelos professores e acesso a e-books e/ou 
apostilas, entre outros materiais. Cabe destacar que nem todos os materiais de apoio foram construídos pelos docentes, já que é possível utilizar uma série de materiais já disponíveis na web, como colocam Parreira, Falkembach e Silveira (2018). Entretanto, as videoaulas foram todas produzidas pelos docentes. Além disso, os 37 materiais destacados na Tabela 1 foram todos desenvolvidos pelos docentes da referida disciplina.

Matricularam-se na disciplina SIN1046, no primeiro semestre de 2021, 48 alunos. No final do semestre letivo foi aplicado um instrumento de pesquisa, construído no Google Forms e disponibilizado de forma on line, para que os acadêmicos pudessem expressar suas opiniões sobre diferentes aspectos que compreenderam os processos de ensino e de aprendizagem na modalidade de ensino remoto. $O$ instrumento contou com 11 perguntas fechadas, utilizando uma escala Likert de cinco pontos (DALMORO; VIEIRA, 2013) com as opções Discordo Totalmente, Discordo, Sem Opinião, Concordo e Concordo Totalmente. Dos 48 matriculados, 30 (representando $62,5 \%$ ) preencheram o referido instrumento. Em cada uma das perguntas fechadas havia um espaço para justificar as respostas (opcional) e, a última pergunta era aberta, destinada a críticas, comentários e sugestões. A Figura 1 apresenta um gráfico destacando o percentual de respondentes para a pergunta: A qualidade das videoaulas estava adequada (layout, fonte utilizada, imagens, etc?).

Todos os respondentes responderam que a qualidade das videoaulas estava adequada, destacando as opções Concordo Totalmente (43,3\%, 13 participantes) e Concordo (56,7\%, 17 participantes). As videoaulas têm sido uma das estratégias mais utilizadas na modalidade de ensino remoto no REDE/UFSM e são uma das bases da metodologia ativa de aprendizagem da sala de aula invertida (BERGMANN, 2018). Considerando o espaço para que os estudantes pudessem justificar suas respostas, destacam-se os seguintes comentários, todos positivos: "Concordo totalmente, todas as videoaulas foram bem explicativas, não deixaram dúvidas sobre os assuntos estudados"; "Aulas em formato de vídeo servem de muito auxílio para quem tem mais dificuldade com algum assunto"; "Os vídeos 
eram longos, mas completos"; "Aulas bem explicativas, conteúdo completo"; "A qualidade estava boa, professor explicou bem as vídeoaulas e foi bem objetivo"; "Particularmente eu prefiro aulas síncronas para sanar dúvidas que podem ocorrer na hora, mas não tive nenhum problema em relação a isto até agora, pois o professor explicou muito bem".

Figura 1 - Gráfico referente à Questão 1

\section{A qualidade das videoaulas estava adequada (layout, fonte utilizada,} imagens, etc)?

\section{0 respostas}
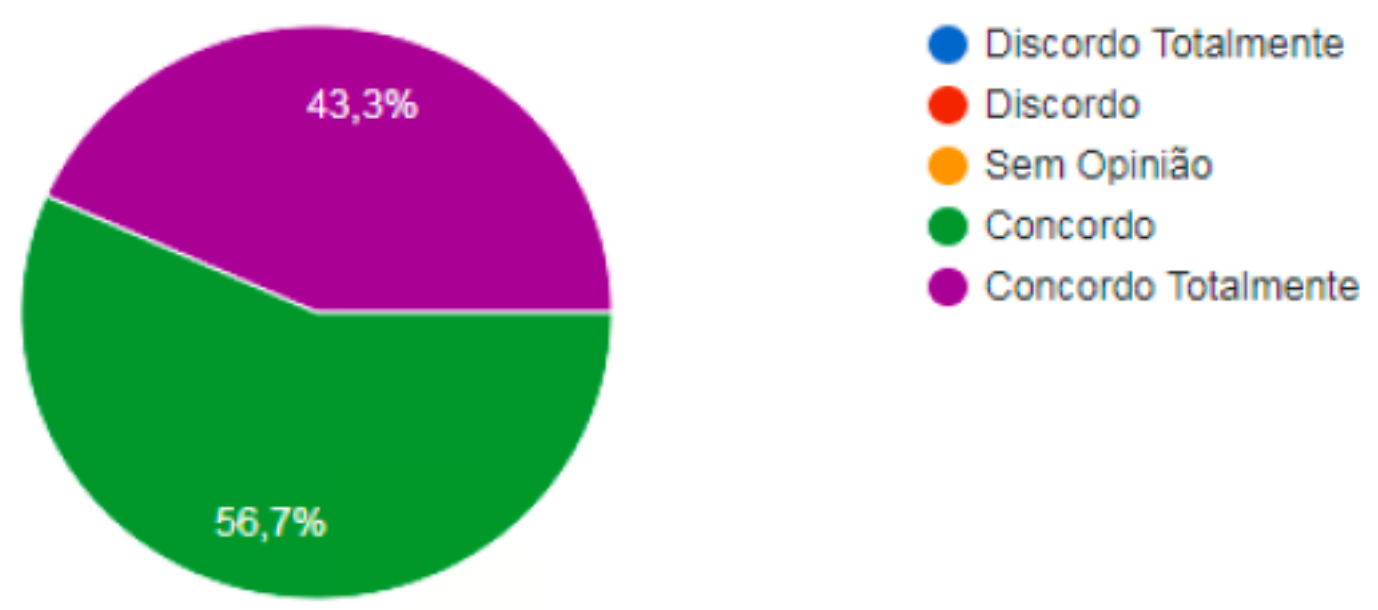

Fonte: Os autores, 2021.

A Figura 2 apresenta os resultados relativos à questão 2: A qualidade do áudio das videoaulas estava adequada? Os resultados são os mesmos da Questão 1 , sendo que $56,7 \%$ dos respondentes (17) concordaram e 43,3\% (13) concordaram totalmente.

Com relação ao áudio das videoaulas, nem todos os comentários dos alunos foram positivos, pois os professores, infelizmente, não dispõem de um espaço profissional para gravação (um estúdio de gravação), realizando-as em suas residências. Os principais comentários foram: "O áudio estava bom para entender perfeitamente, não estava 100\% limpo e talvez desse para melhorar, mas nunca foi um problema para entender as aulas. Além disso, o volume não estava bem consistente entre as aulas, mas isso era mais um pequeno inconveniente de 
mudar o volume e não mesmo um problema”; "Áudio estava muito bom”; "Em alguns momentos, o áudio travava, mas nada que comprometesse o entendimento da aula"; "O áudio está bom, sem travamentos nem outros barulhos"; "Às vezes tinha um ruído, como se fosse uma interferência"

Figura 2 - Gráfico referente à Questão 2

\section{A qualidade do áudio das videoaulas estava adequada?}

\section{0 respostas}

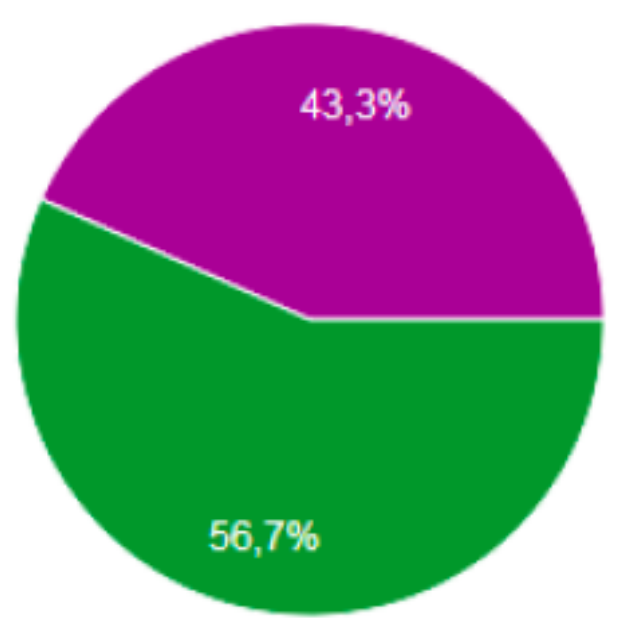

- Discordo Totalmente

- Discordo

Sem Opinião

Concordo

- Concordo Totalmente

Fonte: Os autores, 2021

Seguindo as questões do instrumento de pesquisa, a Figura 3 apresenta os resultados referentes à questão 3: "O número de videoaulas disponibilizadas durante o semestre foi adequado?".

Analisando-se os resultados da questão 3, vê-se que a maioria dos respondentes (53,3\%, 16 alunos) destacou a opção Concordo Totalmente, seguido de Concordo (43,3\%, 13 participantes) e apenas 1 aluno (3,3\%) destacou Sem Opinião. Os comentários sobre esta questão foram: "Acho que teve uma boa frequência"; "Sim, foi uma quantidade boa"; "Achei perfeito dessa forma. Vídeos, relativamente, pequenos e com um conteúdo bem objetivo, com exemplos e comentários que julgo importantes!"; "Esse foi o meu primeiro semestre em uma universidade então por esse motivo eu não tenho $100 \%$ de certeza que a quantidade estava boa". 
Figura 3 - Gráfico referente à Questão 3

número de videoaulas disponibilizadas durante o semestre foi adequado?

30 respostas

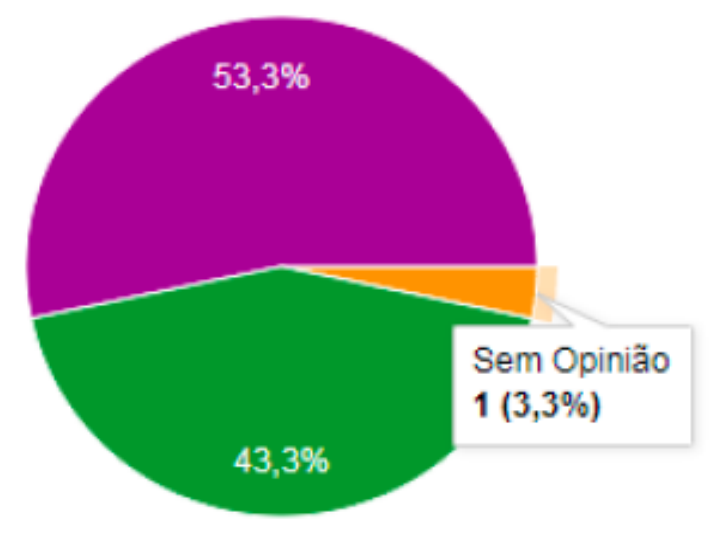

Discordo Totalmente

Discordo

Sem Opinião

Concordo

Concordo Totalmente

Fonte: Os autores, 2021.

Na Figura 4 são apresentados os resultados relativos à questão 4 do instrumento, que dizia: "O número de atividades (exercícios, estudos de caso, projetos, etc.) foi adequado?". A maioria dos respondentes (56,7\%, 17 respondentes) destacou Concordo Totalmente, seguido de Concordo, com 43,3\% (13 estudantes). Os comentários de todos os participantes foram positivos, destacando-se: "Na minha opinião foi um número bom"; "Por mim (pessoalmente) quanto mais melhor"; "Considero a melhor forma de aprender praticando, pois eu gosto de colocar em prática tudo que foi apresentado durante as aulas"; "Tinham um bom tempo para fazer e o assunto sempre era explicado antecipadamente"; "Concordo, pois os exercícios foram bem dinâmicos"; "O número de atividades foi adequado, porém, como aluno deixei a desejar em algumas atividades tendo em vista a quantidade de trabalhos e estudos que foram necessários em outras disciplinas cursadas no mesmo semestre"; "A quantidade não foi excessiva, não chegou a sobrecarregar, e também não deixou lacunas de conhecimento"; "Adorei o tipo de ensino, pra exemplos como eu, de quem não tem muito tempo pra se disponibilizar pra fazer as aulas e questões, vídeo aulas bem explicativas, questões nas atividades nas formas de questionário, com prazos de entrega longos. Nota 10 professor, se adaptou perfeitamente ao tipo de vida levada por certos alunos!". 
Figura 4 - Gráfico referente à Questão 4

\section{O número de atividades (exercicios, estudos de caso, projetos, etc) foi adequado?}

\section{0 respostas}

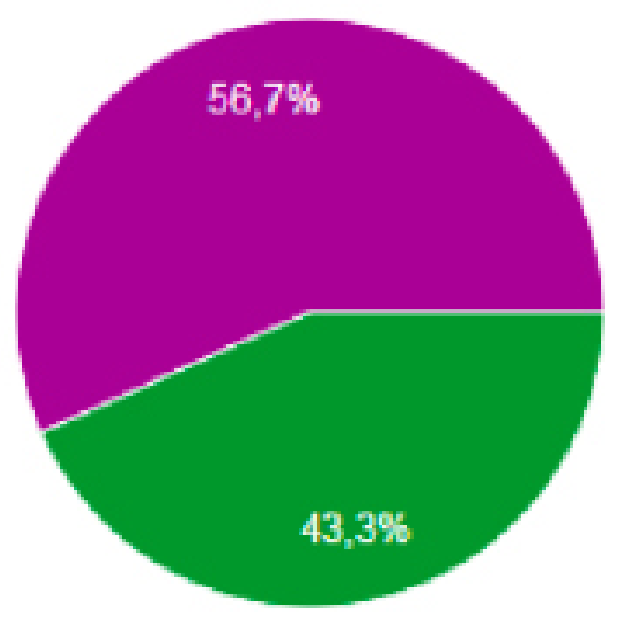

Discordo Totalmente

Discordo

Sem Opinião

- Concordo

- Concordo Totalmente

Fonte: Os autores, 2021.

A questão 5 do instrumento de pesquisa estava relacionada ao feedback das atividades realizadas pelos acadêmicos, a partir da seguinte pergunta: "O feedback (retorno do professor) com relação às atividades foi adequado?". A grande maioria dos respondentes $(83,3 \%, 25$ participantes) destacou Concordo Totalmente, seguidos de 3 alunos (10\%) que responderam Concordo e 2 (6,7\%) Sem Opinião. O feedback é muito importante para motivar e manter os estudantes interessados na modalidade de $\mathrm{EaD}$ e, também, na modalidade de ensino remoto (PEREIRA et al., 2017). Os professores tomaram o cuidado de responderem a todas as postagens nos fóruns de forma individualizada, além de corrigirem todas as atividades e responderem a todas as mensagens encaminhadas pelos acadêmicos. No fórum de notícias, em que são enviadas mensagens para toda a turma, foram 37 mensagens ao todo. Com relação ao feedback dos fóruns de discussão, os mesmos totalizaram 169. Além disso, os professores também enviaram mensagens individualizadas, relacionadas às correções das atividades e, também, para identificar e tentar resgatar os alunos que estavam há muito tempo sem interagir no AVA Moodle. A Figura 5 apresenta os resultados relacionados à questão 5. 
Figura 5 - Gráfico referente à Questão 5

O feedback (retorno do professor) com relação às atividades desenvolvidas foi adequado? 30 respostas

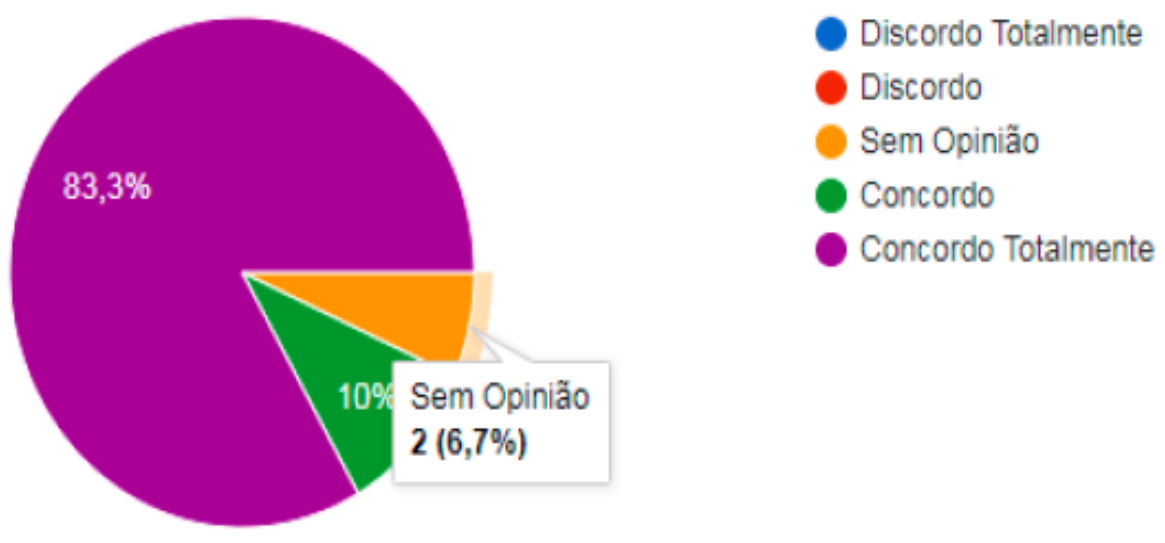

Fonte: Os autores, 2021.

Com relação aos comentários sobre a questão 5 destacam-se: "Professor atualizou as notas com frequência, e quando preciso até cobrou retorno das atividades"; "Senti que o professor foi totalmente compreensivo no meu caso, que acabei atrasando algumas atividades"; "As atividades foram boas para praticar o que foi aprendido; "Essa questão foi simplesmente perfeita, sempre atento às colocações dos alunos para responder e nos ajudar"; "O professor foi atencioso nas respostas de Fóruns"; "O Professor foi atencioso, sempre respondendo aos fóruns e encaminhando notícias sobre o andamento da disciplina"; "Seus retornos são importantes para sabermos se estamos aprendendo de fato o conteúdo"; "Nota 10 também, super carinhoso e atencioso, dando dicas sempre que pode e conselhos sobre os determinados assuntos"; "Ótimo feedback, o mesmo sendo feito de maneira individual para cada aluno, apontando pontos positivos e melhorias que podem ser feitas, tudo isso visando o melhor desempenho acadêmico do aluno em questão".

Dando continuidade à análise das respostas, a questão 6 perguntou: " $O$ tempo de duração das videoaulas foi adequado?". 46,7\% dos respondentes (14 alunos) respondeu Concordo Totalmente, 43,4\% (13 alunos) respondeu Concordo, 2 alunos (6,7\%) destacaram Sem Opinião e 1 aluno (3,3\%) respondeu Dis- 
cordo. Os comentários sobre o tempo de duração das videoaulas foram: "Achei as aulas longas, mas talvez tenha sido necessário"; "Foi um bom tempo. Nem muito longo onde poderíamos nos perder na explicação e nem muito curto. Bem objetivo e de ótima duração"; "Volto a dizer, é meu primeiro semestre. Embora eu tenha compreendido o que foi passado no tempo devido. Na dúvida eu sempre voltava ou acelerava o vídeo"; "Foi adequado para o aprendizado sem ser muito extenso o que contribui no ambiente virtual, pois, uma videoaula muito extensa acaba cansando"; "As aulas, que em geral tinham de 20 a 30 minutos, apesar de ter uma duração boa, por ser bastante conteúdo, às vezes foi um pouco cansativo e difícil para anotar"; "As aulas mais rápidas mantém mais a atenção". Nesta questão, Bergmann (2018) sugere videoaulas mais curtas, de até 8 minutos. Entretanto, para dar conta dos conteúdos da disciplina, seria necessário realizar muitas videoaulas menores para atender o escopo do programa/ementa.

A próxima questão do instrumento, questão 7, compreendia: "O conteúdo $e$ as explicações apresentadas nas videoaulas auxiliaram no desenvolvimento das atividades da disciplina?". A maioria dos respondentes, 23, representando $76,7 \%$, destacaram a opção Concordo Totalmente, seguida de 20\% (6 alunos) que destacaram Concordo e 1 aluno (3,3\%) que respondeu Sem Opinião. Os participantes realizaram os seguintes comentários sobre essa questão: "Sim, atividades bem elaboradas de acordo com o que foi apresentado nas aulas"; "Bem explicadas, com todos os temas das perguntas, tornando possível responder os questionários".

A próxima questão (questão 8) era sobre o aluno fazer anotação enquanto assistia às videoaulas: "Você fez anotações enquanto assistia às videoaulas?". Segundo Bergmann (2018), as anotações, na metodologia da sala de aula invertida, devem ser incentivadas pelos professores e utilizadas nos momentos de interação. Os professores podem pedir que os alunos anotem o que aprenderam na videoaula e elaborem perguntas, sendo perguntas para debate e/ou discussão entre a turma e, também, dúvidas sobre os conteúdos apresentados. Sendo assim, nesta disciplina os professores pediram para os alunos fazerem 
anotações durante as videoaulas e, por meio dos fóruns de discussão, utilizaram as anotações para desenvolver atividades e fornecer o feedback para os alunos. Entre as estratégias utilizadas destacam-se: em um dos fóruns de discussão os alunos tinham que responder: "O que você aprendeu com a videoaula", a partir de uma videoaula sobre a carreira profissional na área de Tecnologia da Informação. Em outra videoaula, sobre Comércio Eletrônico e Sistemas de Recomendação, os professores pediram para que os estudantes elaborassem perguntas sobre o conteúdo e postassem as mesmas no fórum de discussão. Cabe destacar que todas as perguntas foram respondidas pelos professores, articulando-as aos conteúdos abordados na disciplina.

Uma das questões que envolvem a modalidade de ensino remoto (e até mesmo a modalidade de EaD) é a realização de atividades síncronas e/ou assíncronas. Na disciplina apresentada aqui neste relato de experiências, foram utilizadas atividades nestas duas formas. Por exemplo, as lives eram síncronas mas os fóruns de discussão eram assíncronos. Sendo assim, perguntou-se para os alunos a preferência dos mesmos sobre a forma síncrona ou assíncrona, mais especificamente relacionadas às videoaulas.

A questão 9 destacou: "Você prefere que as videoaulas sejam gravadas antecipadamente e disponibilizadas no YouTube (modo assíncrono)?". A maioria dos respondentes (50\%, 15 alunos) destacou Concordo Totalmente, seguidos de 11 alunos (36,7\%) que destacaram Concordo. 3 alunos responderam Sem Opinião (10\%) e 1 aluno (3,3\%) respondeu Discordo. Acredita-se que os acadêmicos prefiram o modo assíncrono, pois podem assistir às videoaulas nos dias e horários mais adequados, de acordo com a agenda de cada um. Os principais comentários destacam: "Prefiro assim, pois posso assistir às aulas até com antecedência, e assim adiantando as atividades para fazer, o que também dá um fôlego a mais para fazer atividades de outras disciplinas quando já sei que essas já estão prontas"; "Esse método é bem interessante pois permite ao aluno adaptar as aulas a sua rotina, possibilitando a flexibilização do acesso ao conteúdo, além de permitir revisão para algum ponto que não tenha entendido em um primeiro 
momento (...); "Esse formato é muito mais fácil e confortável para nós alunos".

Ainda com relação ao modo das videoaulas (síncrono ou assíncrono), a questão 10 compreendia: "Você prefere que as videoaulas sejam on line, no formato de lives?". Apenas 1 aluno (3,3\%) respondeu Concordo Totalmente, seguido de 5 alunos (16,7\%) que destacaram Concordo, 11 (36,7\%) Sem opinião, 9 (30\%) Discordo, 4 (13,3\%) Discordo Totalmente. Os resultados corroboram as opiniões e os resultados já apresentados na questão anterior, de que a preferência dos alunos é pela realização de videoaulas gravadas (modo assíncrono), possibilitando maior liberdade para que se organizem durante o semestre. Os respondentes destacaram os seguintes comentários com relação à questão 10: "Para mim, especificamente, foi melhor que as videoaulas tenham sido gravadas, já que acabei ficando um tempo sem computador e não conseguiria fazer as atividades (...)"; “(...) o formato ao vivo (...) só me deixa ainda mais desconfortável em relação a fazer perguntas, pois aqui em casa eu não tenho muita privacidade, muito ruído, barulho e etc... Que não me ajudam com aulas ao vivo, sempre acabo perdendo alguma explicação/comentário sobre algo"; "Gravadas, de forma assíncrona, da maneira que se apresentaram nesta disciplina neste semestre"; "Quando as aulas já são gravadas nós podemos assistir assim que possível e retornar o conteúdo caso houver dúvidas, pois muitas vezes em questão do horário de trabalho não é possível assistir a aula no mesmo horário que está marcada"; "Acredito que a opção de assistir as vídeoaulas de acordo com a disponibilidade individual do aluno é de fundamental importância, até mesmo pelo curso ser noturno".

Na questão 11 perguntou-se: "Qual foi, ou quais foram, as maiores dificuldades para você estudar de forma remota, de acordo com o REDE - Regime Especial Domiciliar de Estudos da UFSM?". Nessa questão os respondentes podiam marcar várias opções. As principais colocações dos alunos foram: sinto falta de contato com os professores e com os colegas (19 alunos, 63,3\%), prefiro as aulas presenciais (16 alunos, 53,3\%), não me adapto à modalidade de ensino remoto (8 alunos, 26,7\%). No espaço para comentários os participantes destacaram: "Acho que as aulas presenciais sempre serão melhores, o contato direto 
com o professor e colegas é insubstituível"; "Me distraio bastante em casa, pois ainda não consigo me acostumar em casa e sabendo que tenho obrigações, pois vejo minha casa como lazer"; "Com relação a esta disciplina não tive problemas. No entanto com outra que foi realizada de forma síncrona (...) percebi um pouco de dificuldade para resolução de dúvidas, vez que são muitos alunos e muitas vezes através do Moodle fica confusa a ordenação das perguntas e respostas (...)"; "Consigo me adaptar ao formato on-line, mas tive dificuldade em gerenciar o tempo e ter motivação para fazer as atividades"; "As experiências nas aulas presenciais tornam o aprendizado em geral muito melhor"; "O estudo por meio do REDE, tem dificultado muito a aprendizagem, pois presencial é mais fácil de tirar dúvidas com o professor ou colegas".

A questão 12 do instrumento de pesquisa era um espaço aberto para os alunos realizarem críticas, sugestões e outros comentários. Os estudantes destacaram nessa questão: "A abordagem e técnica utilizadas pelo professor foram satisfatórias, o método de avaliação adequado e a disponibilidade e atenção sempre presentes nas comunicações realizadas. Ótimas aulas, atividades prazerosas e agregadoras de conhecimento"; "Disciplina muito bem ministrada, é perceptível o domínio do professor em relação ao assunto"; "Em suma, suas aulas são muito boas professor, dá para notar que o senhor gosta do que transmite, colaborando para que o entendimento sobre o assunto seja de forma mais tranquila"; "Estou cursando 4 Disciplinas esse semestre, a única matéria mais bem organizada no Moodle foi SI, gostei da disponibilidade de entrega dos trabalhos não tinha data $x$ para finalizar isso me deu mais tempo de entrar no Moodle olhar os vídeos e fazer os exercícios e trabalhos propostos... porque as vezes não consigo estar presente no Meet. por causa do serviço e da correria do dia..."; "Adoro as aulas, bem explicativo e objetivo"; "A escolha de aulas assíncronas liberando espaço e tempo para os alunos escolherem o momento de fazer e entregar as atividades foi muito boa, ao meu ver. Isso porque consigo me programar para fazer as atividades e não fico me cobrando por algo que posso ter esquecido ou que passou da data de entrega"; "Não tenho críticas sobre o andamento da disciplina. Achei interessante a forma de apresentação do conteúdo e o formato das aulas, além 
do feedback do professor"; Eu particularmente gostei muito dessa disciplina, das aulas e a didática do professor".

\section{CONSIDERAÇÕES FINAIS}

Este capítulo apresentou um relato de experiências sobre o emprego da metodologia ativa de aprendizagem da sala de aula invertida na modalidade de ensino remoto, de acordo com o REDE/UFSM (UFSM, 2021), na disciplina SIN1046 Sistemas de Informação, do Curso de Bacharelado em Sistemas de Informação do Campus de Frederico Westphalen/RS. O foco principal foi o de apresentar as opiniões dos ingressantes do curso, que iniciaram as atividades acadêmicas no $1^{\circ}$ semestre letivo de 2021, por meio da aplicação de um instrumento de pesquisa. Os resultados do referido instrumento são positivos, pois a maioria dos alunos demonstrou estar satisfeita com relação à metodologia empregada pelos professores.

As Tecnologias Digitais da Informação e da Comunicação têm sido grandes aliadas do ensino remoto, permitindo o desenvolvimento das atividades letivas em meio ao isolamento social provocado pela Pandemia de COVID-19. O isolamento social e a suspensão das atividades presenciais nas instituições de ensino, devido à pandemia de COVID-19, trouxe uma situação até então não vivenciada pelos professores e alunos, de diferentes níveis de ensino. Até mesmo os professores e alunos de cursos da área de Informática, acostumados a utilizarem as TDIC diariamente (seja no ambiente educacional ou no ambiente profissional) sentiram os impactos do isolamento, principalmente pela falta de contato presencial.

O relato de experiências aqui apresentado demonstrou que as vídeoaulas, sejam no modelo on line (ou lives) ou gravadas e disponibilizadas no YouTube, foram um dos recursos mais utilizados. Acredita-se que este seja um dos instrumentos mais importantes para apoiar os processos de ensino e de aprendizagem a distância, seja na modalidade de ensino remoto ou de EaD, possibilitando minimizar os impactos negativos do isolamento social. Além disso, as videoaulas são 
um instrumento importante para a aplicação de metodologias ativas de aprendizagem, tais como a sala de aula invertida (BERGMANN, 2018). Sendo assim, por meio de videoaulas, os alunos podem estudar os conteúdos conceituais das disciplinas por meio da web e revê-las quantas vezes forem necessárias.

\section{REFERENCIAS}

BERGMANN, J. Aprendizagem Invertida para resolver o Problema do Dever de Casa. Porto Alegre: Penso, 2018.

BERGMANN, J.; SAMS, A. Sala de Aula Invertida: uma metodologia ativa de aprendizagem. Rio de Janeiro: LTC, 2018.

DALMORO, M.; VIEIRA, K. M. Dilemas na Construção de Escalas Tipo Likert: o Número de Itens e a Disposição Influenciam nos Resultados? Revista Gestão Organizaconal, v. 6, n. 3 (2013), Rio de Janeiro: p. 161-174. Disponível em: https://bell.unochapeco.edu.br/revistas/index.php/rgo/article/view/1386. Acesso em 03 set. 2021.

FRANCO, S. R. K. O Construtivismo e a Educação. Porto Alegre: Artes Médicas, 2004.

PARREIRA, F. J.; FALKEMBACH, G. A. M.; SILVEIRA, S. R. Construção de Jogos Educacionais Digitais e Objetos de Aprendizagem: um estudo de caso empregando Adobe Flash, HTML 5, CSS, JavaScript e Ardora. Rio de Janeiro: Ciência Moderna, 2018.

PAVANELO, E.; LIMA, R. Sala de Aula Invertida: a análise de uma experiência na disciplina de Cálculo I. Bolema: Boletim de Educação Matemática, v. 31, n. 58, ago. 2017. Disponível em: https://www.scielo.br/scielo.php?script=sci_arttext\&pi$\mathrm{d}=$ S0103-636X2017000200739. Acesso em: 23 jul. 2020.

PEREIRA, A. S.; PARREIRA, F. J.; BERTAGNOLLI, S. C.; SILVEIRA. S. R. Metodologia da Aprendizagem em EaD. Santa Maria, RS: UAB/NTE/UFSM, 2017. Disponível em: https://repositorio.ufsm.br/handle/1/15809. Acesso em: 15 abr. 2020

SILVEIRA, S. R.; BERTOLINI, C.; PARREIRA, F. Formação Docente: como empregar metodologias ativas de aprendizagem em meio à pandemia de COVID-19 (e-book). In: Marcos Pereira dos santos. (Org.). Formação Docente: importân- 
cia, estratégias e princípios. 1ed. Curitiba - PR: Bagai, 2020, v. 1, p. 107-119. Disponível em: https://editorabagai.com.br/wp-content/uploads/2020/06/Editora-BAGAI-Forma\%C3\%A7\%C3\%A3o-Docente-Volume-I.pdf . Acesso em: 17 jul. 2020.

TUCKER, B. The Flipped Classroom: online instruction at home frees class time for learning. 2012. Disponível em: http://www.msuedtechsandbox.com/MAETELy2-2015/wp-content/uploads/2015/07/the_flipped_classroom_article_2.pdf. Acesso em: 12 jul. 2020.

UFSM. Universidade Federal de Santa Maria. Resolução 024 de 11 de agosto de 2020: Regula o Regime de Exercícios Domiciliares Especiais (REDE) e outras disposições afins, durante a Suspensão das Atividades Acadêmicas Presenciais em face da Pandemia da COVID-19. Disponível em: https://portal.ufsm.br/ documentos/download.html;jsessionid=03d73ba98226610100d73c9e39d1?action=arquivos Indexados\&download=false\&id=13137456. Acesso em: 31 ago. 2020.

UFSM. Universidade Federal de Santa Maria. Resolução 042/2021: Estabelece que a Resolução N. 024, de 24 de 11 de agosto de 2020 passa a vigorar com as seguintes alterações. Disponível em: https://www.ufsm.br/pro-reitorias/proplan/ resolucao-ufsm-n-042-2021/. Acesso em: 04 set. 2021. 


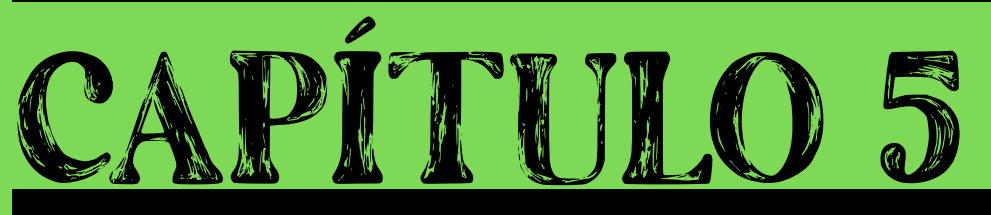

\section{O USO DAS TECNOLOGIAS} DIGITAIS DA INFORMAÇÃO E COMUNICAÇÃO COMO MEDIADORAS NO PROCESSO DE ENSINO E APRENDIZAGEM EM UMA ESCOLA DO CAMPO

Luciane M. Schlottfeldt Janilse. F. Nunes 


\section{INTRODUÇÃO}

A escola é o espaço onde se proporcionam encontros entre educadores e educandos, entre currículos, materiais de ensino e processos formativos, os quais permitem compreender como as práticas de ensino se articulam com os diversos elementos socio-históricos que os constituem (MARANDINO; SELLES; FERREIRA, 2009).

No entanto, em determinadas instituições de ensino, está sendo incentivada a criação de espaços educativos para o envolvimento dos educandos e educadores no processo de ensino e aprendizagem. Esses locais muitas vezes são salas de aula ou outros ambientes com uma dinâmica diferenciada na relação entre educandos e educadores, primando pela horizontalidade das relações que perpassam, inclusive, a disposição dos mobiliários. São relações mais informais das que se dão nas salas de aulas propriamente ditas. Nesses, os participantes sentem-se comprometidos no processo educativo e convidados a interagir concretamente com as propostas de trabalho (SCHLOTTFELDT, 2018).

É evidente o crescimento de uso das Tecnologias Digitais da Informação e Comunicação (TDICs) na atualidade. O crescimento pela procura por celulares, televisões digitais, tablets e smartphones com conexão à internet aumentou muito no Brasil. São aproximadamente 33 milhões de residências brasileiras que apresentam computadores, somando 100\% entre o período de 2008 a 2015. Quanto ao acesso à internet, $51 \%$ dos lares brasileiros têm acesso à rede mundial, com crescimento de $9 \%$ para os que utilizam a internet fora de seus domicílios com equipamentos móveis (LIMA; LOUREIRO; TELES, 2017).

Conforme Lima, Loureiro e Teles (2017, p. 17):

A interdisciplinaridade pressupõe a integração entre saberes que estabelecem necessidades de trocas conceituais entre seus participantes pelo compartilhamento de conhecimentos, reflexões, discussões conjuntas e aprendizagens mútuas. As transformações que advêm com a utilização das TDICs de forma interdisciplinar no âmbito da docência auxiliam na execução das tarefas docentes por meio da construção colaborativa do conhecimento diante de trocas que aumentam o escopo cultural dos participantes. O trabalho interdisciplinar com a integração entre TDICs e 
docência proporciona indícios de ressignificações conceituais nos licenciandos que finalizam o processo de ensino, aprendizagem e avaliação mesclando ideias antigas e inovadoras sobre docência.

É incontestável que a tecnologia está cada vez mais presente, sendo que os investimentos e as inovações tecnológicas são resultados da necessidade constante do ser humano em potencializar as suas capacidades e melhorar a sua condição de vida (CASTELLS, 2000). Devido à penetrabilidade em diferentes áreas na esfera das aprendizagens (formal, não formal e informal), a evolução tecnológica digital tem assumido um papel determinante no reconfigurar dos ecossistemas e ambientes educacionais e, portanto, ignorar essas tecnologias é descurar o seu potencial para propiciar a inovação, transformação e modernização (MOREIRA, 2018).

Nos dias de hoje, os educadores precisam estar em constante atualização usando as TDICs a serviço da Educação. Um dos grandes desafios é a adaptação dos educadores que não tiveram a formação acadêmica sobre o uso das TDICs para atuar no ensino e aprendizagem.

Conforme descrito em Bollela et al. (2014, p. 294):

O TBL tem particularidades (descritas ao longo deste texto) que o diferenciam de outras estratégias para ensino em pequenos grupos, incluindo o PBL (problem-based learning ou aprendizagem baseada em problemas). O TBL pode substituir ou complementar um curso desenhado a partir de aulas expositivas, ou mesmo aplicando outras metodologias. Não requer múltiplas salas especialmente preparadas para o trabalho em pequenos grupos, nem vários docentes atuando concomitantemente. Além disso, propõe-se a induzir os estudantes à preparação prévia (estudo) para as atividades em classe.

Pretende-se por meio deste trabalho descrever o relato de experiência dos educadores construído na proposta de trabalho de associar os conhecimentos teóricos de sala de aula em conjunto com os saberes tradicionais do campo, as TDICs, dentro da metodologia de trabalho Team-Based Learning (TBL) em uma Escola do Campo Municipal de Ensino Fundamental localizada na zona rural de Santa Maria, RS com os educandos dos anos finais no $9^{\circ}$ ano, tendo a finalidade de compartilhar as atividades desenvolvidas. 
O objetivo do estudo em questão foi o de proporcionar a utilização das TDICs como ferramentas de apoio pedagógico na construção de aprendizagens ativas pela estratégia educacional (TBL) na Escola de Campo Escola Municipal de Ensino Fundamental Intendente Manoel Ribas (EMEFIMR), pertencente ao Distrito de Santo Antão, no município de Santa Maria.

\section{MATERIAIS E MÉTODOS}

Conforme Gil (2008), a pesquisa pode ser definida como o procedimento racional e sistemático cujo objetivo é proporcionar respostas aos problemas que são propostos, sendo a pesquisa requerida quando não dispõe de informação suficiente para responder ao problema, ou então, quando a informação disponível se encontra em tal estado de desordem que não possa ser adequadamente relacionada ao problema.

Este trabalho trata-se de um relato de experiência desenvolvido na disciplina de Tecnologias de Informação e Comunicação no Ensino de Ciência e Matemática vinculada ao curso de Doutorado do Programa de Pós-graduação em Ensino de Ciências e Matemática (PPGECIMAT) da Universidade Franciscana (UFN). A proposta de trabalho desenvolvida na disciplina foi feita mediada por tecnologias digitais, com a metodologia de trabalho Team-Based Learning (TBL). Tratando-se da preservação do meio ambiente como condição básica para qualidade de vida, as habilidades desenvolvidas estão de acordo com o código EF09C113RS-3. Tendo como objetivo identificar hábitos individuais e coletivos que tenham impacto no meio ambiente, buscando associar consumo consciente e ações sustentáveis para mitigação do problema do Currículo Emergencial do município de Santa Maria, RS, o Eixo Temático trata-se de Vida e Evolução, e o Objeto do Conhecimento é a preservação da biodiversidade.

A metodologia do ensino foi a aprendizagem baseada em equipes da teoria prática TBL, onde foram desenvolvidas 05 (cinco) atividades, sendo elas expressas no decorrer do trabalho e ocorridas em uma escola do campo de- 
nominada Escola Municipal de Ensino Fundamental Intendente Manoel Ribas (EMEFIMR), pertencente ao Distrito de Santo Antão, do município de Santa Maria RS. A escola atua na busca de uma educação de qualidade, respeitando as peculiaridades da escola do campo (EMEFIMR, 2018), e com base nas Diretrizes Operacionais para a Educação do Campo.

A ideia de organizar novas experiências por meio de aulas junto à Disciplina de Ciências da Natureza surgiu da necessidade da ampliação de espaços pedagógicos para além da escola, a fim de que houvesse a valorização dos espaços não formais disponíveis nas plataformas virtuais, aproximando ainda mais o educando a diferentes formas de ensino e de aprendizagem. Para além disso, não basta trabalhar com tecnologias digitais sem a utilização de uma metodologia diferenciada, interativa e dinâmica, com o intuito de compartilhar os saberes tradicionais do campo com os conhecimentos científicos associados com a valorização do meio ambiente. Após, foi traçado um esboço na plataforma digital Padlet, apresentado pela Figura 1, e encaminhado para a aprovação da equipe escolar. Quando aprovado, ocorreu a organização da sequência do tema e das aulas propostas.

Figura 1 - Planejamento das aulas realizadas na EMEFIMR, 2021

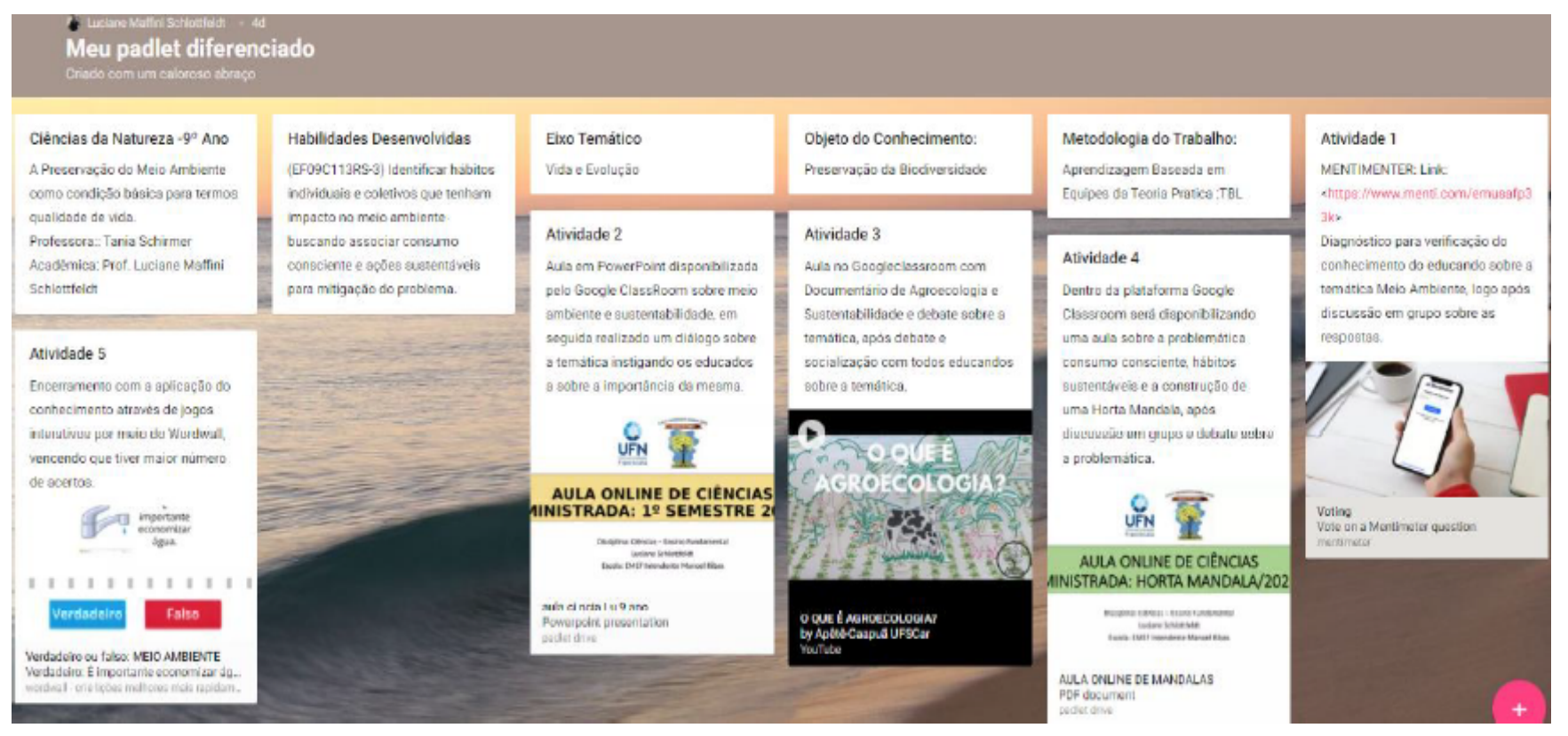

Fonte: As autoras. 


\section{RESULTADOS}

Compreender as práticas que os educadores desenvolvem dentro das escolas do campo torna-se fundamental para significar o processo de aprendizagem. Talvez o grande desafio a ser cumprido pelos educadores é o de associar as TDICs, a Educação do Campo e a TBL, uma vez que o conhecimento deve ser acessível ao educando conforme os avanços das tecnologias no processo global.

O planejamento, conforme disponível na plataforma digital Padlet, está disponível através do link: <https://padlet.com/Imaffini/agdon0aycivlwmza> e foi organizado dentro do conteúdo das Ciências da Natureza, para o $9^{\circ}$ ano do ensino fundamental, contemplando 15 educandos. Contudo, são apenas seis educandos que possuem acesso às TDICs, então, com esses foram realizadas as atividades on-line. Com os demais educandos foram encaminhadas as atividades impressas, com o tema "A Preservação do Meio Ambiente como condição básica para termos qualidade de vida", ministrado na turma da educadora Tania Schirmer pela acadêmica de Doutorado Prof. Ma. Luciane Maffini Schlottfeldt. As habilidades desenvolvidas são de identificar hábitos individuais e coletivos que tenham impacto no meio ambiente, buscando associar consumo consciente e ações sustentáveis para mitigação do problema. Já o eixo temático é vida e evolução, o objeto do conhecimento trata-se da preservação da biodiversidade, e a metodologia do trabalho é a aprendizagem baseada em equipes da teoria prática TBL.

Foram desenvolvidas cinco atividades, todas elas fundamentadas na TBL, no trabalho em busca da solução das problemáticas levantadas durante as discussões das aulas ministradas, onde o objetivo é o de promover a troca de conhecimento entre os educandos e exercitar suas capacidades de comunicação em busca da atividade. A primeira atividade foi expressa na plataforma digital Mentimenter, disponível pelo link: <https://www.menti.com/emusafp33k>, e os educandos deveriam responder a problemática expressa na pergunta "Para você, o 
que é Meio Ambiente?". Logo após, as respostas eram discutidas em grupo, surgindo, desse modo, cinco respostas, conforme pode ser observado na Figura 2.

O avanço das tecnologias digitais está fazendo com que a evolução passe do processo analógico para a tendência do digital. A Internet e as tecnologias são tendências contemporâneas presentes em quase todos os ambientes, tonando-se parte das compras, do consumo, das mídias, da indústria, das relações culturais e sociais de um mundo em que a colaboração e a interação estão ultraconectados (SILVA; TAROUCO, 2018).

Figura 2 - Atividade na plataforma digital Mentimenter realizado na EMEFIMR, 2021

\section{Mentimeter}

Para você o que é Meio Ambiente? Responda com suas palavras.

Clique no botão para participar!

Abrir oQ\&A

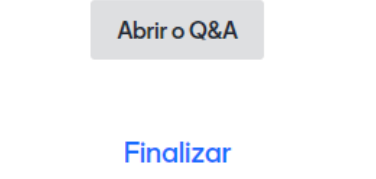

Powered by Mentimeter Terms

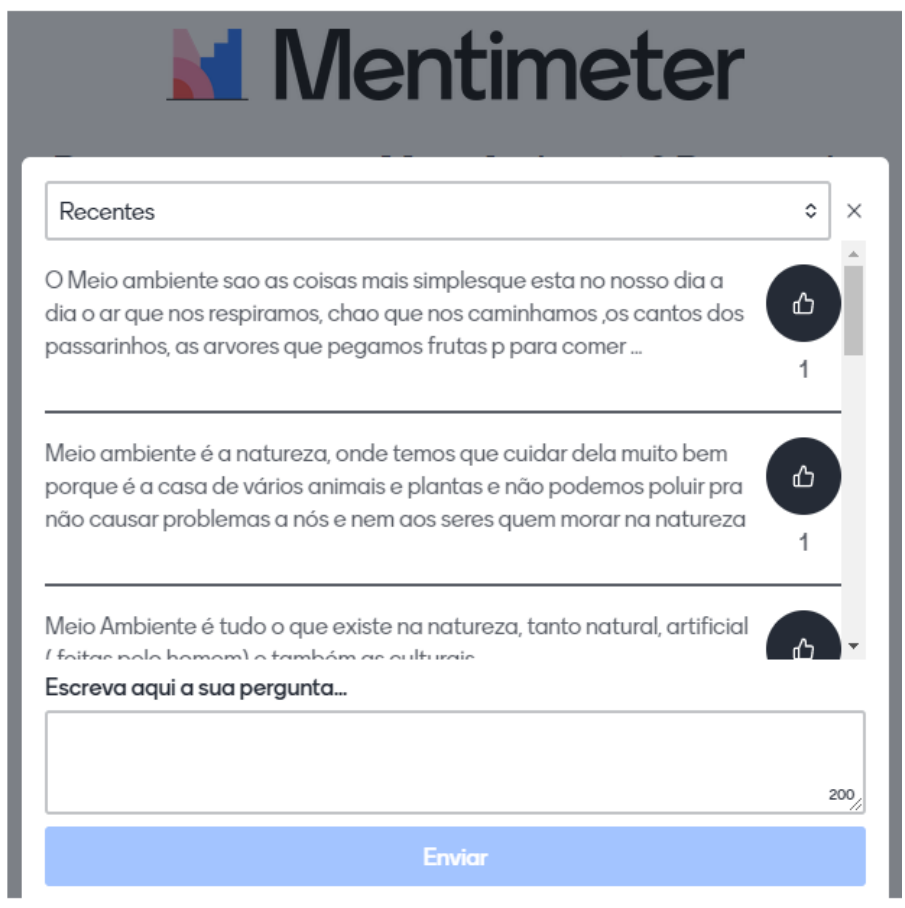

a coisas mais simplesque esta no nosso dia a dia o ar que nos respiramos, chao que nos caminhamos, os cantos dos assarinhos, as arvores que pegamos frutas p para comer

Meio ambiente é a natureza, onde temos que cuidar dela muito bem porque é a casa de vários animais e plantas e não podemos poluir pra hão causar problemas a nós e nem aos seres quem morar na natureza 
Figura 3 - Atividade na plataforma digital Mentimenter realizado na EMEFIMR, 2021

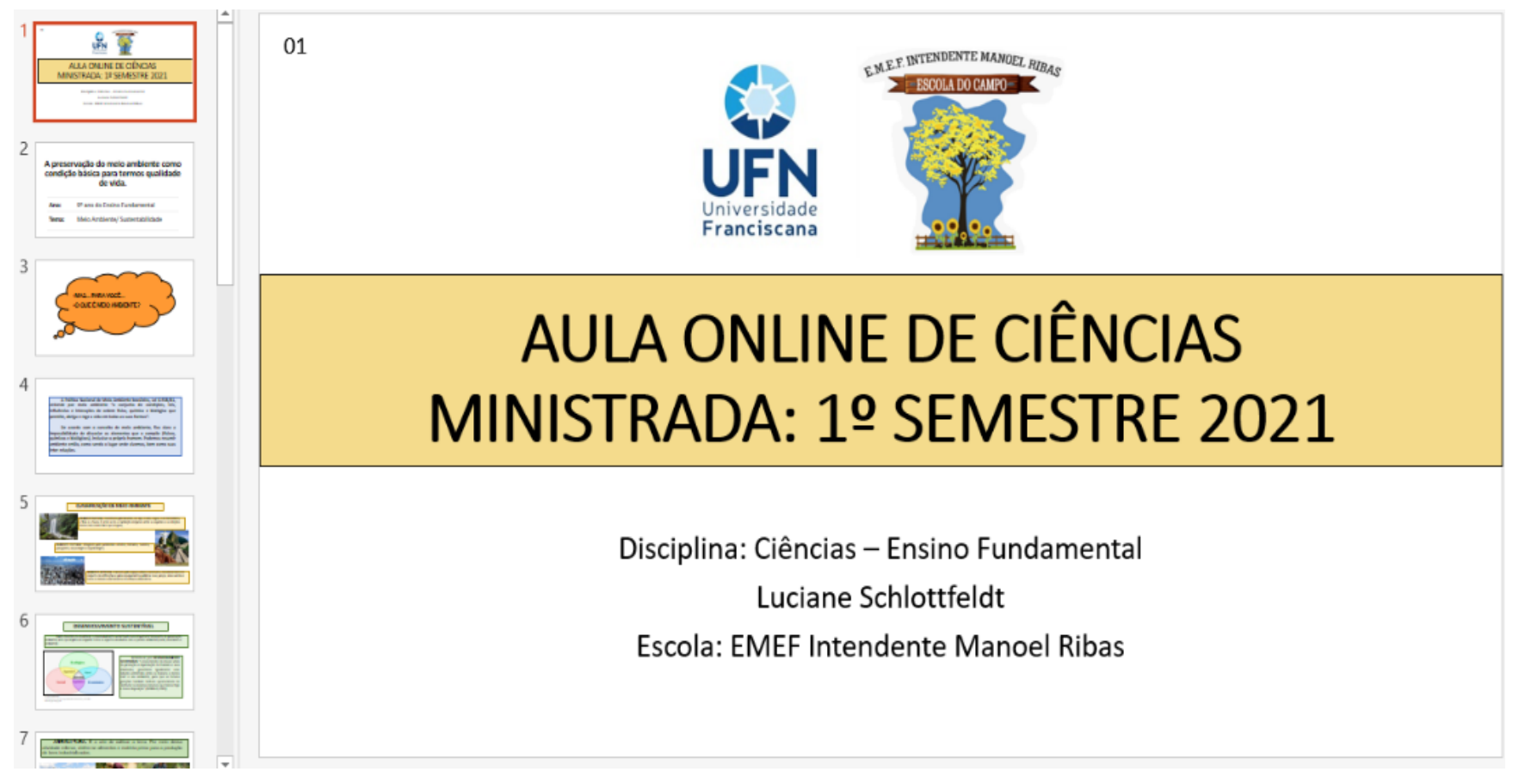

Fonte: As autoras.

Por meio da integração de tecnologia na educação, as TDICs são capazes de trazer benefícios para diversas áreas. Dentre estas, se encontra a educação, onde o conceito de sala de aula aumenta, uma vez que o acesso à internet favorece o uso de mídias, como vídeos on-line, imagens, podcasts, games, entre outros. O uso da tecnologia tem muito a favorecer, dado que os professores podem otimizar muitas de suas funções e torná-las mais fáceis, como correção de trabalhos escolares, por exemplo (SILVA et al., 2017).

A terceira atividade foi uma aula no Google Classroom com um Documentário de Agroecologia e Sustentabilidade. Após, realizou-se um debate e socialização com todos educandos sobre a temática, disponibilizada no link <https:// www.youtube.com/watch?v=gYzGk5y0b7A>, onde participaram seis educandos. A educação abrange mais do que a proporção entre a relação com o saber, envolvendo também a socialização, a fim de possibilitar a convivência em grupo. Em termos educacionais, é extraordinário que os alunos interajam e também construam conhecimentos através das trocas de experiências (FERREIRA; RIBEIRO; BEHAR, 2017). 
A quarta atividade na plataforma Google Classroom foi uma aula sobre as problemáticas consumo consciente e hábitos sustentáveis e a construção de uma Horta Mandala. Após discussão em grupo e debate sobre a problemática, participaram seis educandos e tiveram cinco devolutivas, conforme compreendido pela Figura 4.

Figura 4 - Atividade na plataforma digital Mentimenter realizado na EMEFIMR, 2021

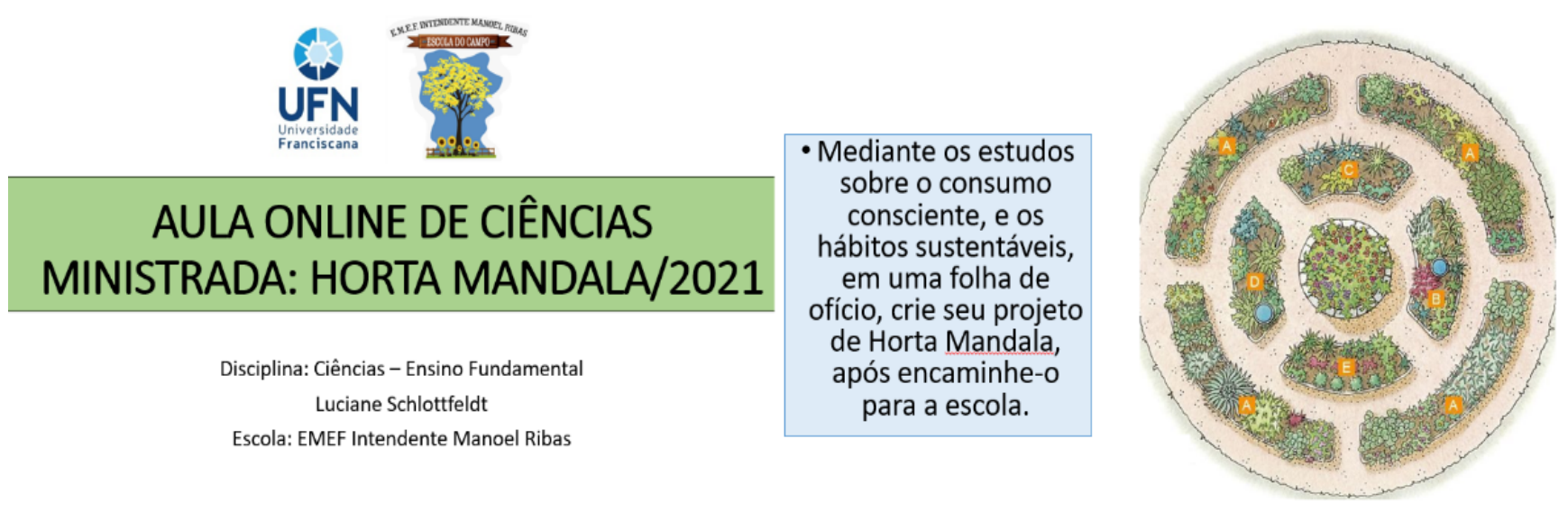

Fonte: As autoras.

De acordo com Bollela et al. (2014, p. 294), entende-se que o TBL:

Tem sua fundamentação teórica baseada no construtivismo, em que o professor se torna um facilitador para a aprendizagem em um ambiente despido de autoritarismo e que privilegia a igualdade. As experiências e os conhecimentos prévios dos alunos devem ser evocados na busca da aprendizagem significativa. Neste sentido, a resolução de problemas é parte importante neste processo. Além disso, a vivenciada aprendizagem e a consciência de seu processo (metacognição) são privilegiadas.

Dessa maneira, essa proposta encontra-se ancorada no processo de estudo e de metacognição do estudante, que, ao longo do desenvolvimento das atividades, realizou diferentes ações que visassem o seu protagonismo, sua capacidade de estudo, significação e apropriação individual e/ou coletiva.

A metacognição apresenta duas dimensões: conhecimento metacognitivo e a regulação metacognitiva, conforme o Quadro 1. 
Quadro 1 - As dimensões da metacognição

\begin{tabular}{|c|c|}
\hline $\begin{array}{c}\text { Conhecimento metacognitivo } \\
\text { É um conhecimento com base nas } \\
\text { habilidades cognitivas do estudante; } \\
\text { é a tomada de conhecimento sobre a } \\
\text { habilidade. }\end{array}$ & $\begin{array}{c}\text { Condição de avaliar a execução da tarefa } \\
\text { e fazer ajustes necessários para } \\
\text { aprender. }\end{array}$ \\
$\begin{array}{c}\text { Ex.: "verificar se vocên } \\
\text { compreende o que está lendo". }\end{array}$ & $\begin{array}{c}\text { Ex.: "reler um parágrafo, ou ler mais } \\
\text { devagar para garantir melhor } \\
\text { compreensão". }\end{array}$ \\
\hline
\end{tabular}

Fonte: Adaptado de Nelson e Narens (1994).

A quinta atividade foi o encerramento por meio da aplicação do conhecimento com jogos interativos por meio do Wordwall, vencendo quem tivesse maior número de acertos, disponível pelo link < https://wordwall.net/pt/resource/8426452/ verdadeiro-ou-falso-meio-ambiente>, onde participaram cinco educandos. Nas TDICs, se fazem presentes novas formas de interação e comunicação em tecnologias, possibilitando a realização de trocas de informações e cooperações e permitindo o desenvolvimento do diálogo, a troca de conhecimentos, a produção coletiva, a investigação colaborativa e a distribuição de informações (KENSKI, 2008).

Portanto, pode-se observar, no decorrer desta proposta, um aumento significativo no interesse dos educandos em participar das aulas, houve uma maior motivação na prática de atividades propostas. Nota-se, também, o interesse dos alunos em participar efetivamente. Indicando e sugerindo alternativas ao encontro dessa experiência, Freire (2011) relata que o aprendizado deve ser educado por meio de um compartilhamento de pessoas, mediatizados pelos saberes do mundo. Nesse contexto, é importante que o espaço escolar se aproprie das TDICs para buscar a construção do conhecimento, e que venha a somar no processo de ensino aprendizagem de educadores e educandos em todos os aspectos. 


\section{CONSIDERAÇÕES FINAIS}

Por meio das aulas de TDICs, é possível ressaltar a importância de novos aprendizados na escola do campo. O entendimento é relacionando os saberes diversificados expresso na parceria entre as TDICs e o campo no desenvolvimento de uma aprendizagem contínua. O educando aprende em todos seus espaços de convivência, não somente no ambiente escolar. E se não ocorrer à parceria entre ambas, a educação será falha.

Salienta-se, também, que a experiência de expandir os espaços pedagógicos da escola com o uso das TDICs foi extremamente satisfatória, visto que houve mudança no comportamento dos educandos em relação à forma com que o conteúdo foi desenvolvido, tornando as atividades e os educandos mais participativos, críticos e reflexivos. Acredita-se ter alcançado os objetivos propostos junto à proposta de aulas sobre o meio ambiente na disciplina de Ciências da Natureza, repensada e melhorada para continuar a atender as especificidades dos educandos do campo.

Por conseguinte, todas as escolas, incluindo as do campo, precisam vivenciar experiências com os educandos conectadas com a atualidade, com a vida no cotidiano e acompanhar as evoluções da ciência. Uma das formas de proporcionar esse acompanhamento é o uso das tecnologias digitais e cabe ao educador ser um agente mediador do conhecimento nesse processo. Entretanto, acrescenta-se que educar é um ato grandioso para quem educa em qualquer meio social e etapa da vida futura do educando, portanto a educação deve ser continuada, humanizada e respeitada.

\section{REFERÊNCIAS}

BOLLELA, V. R. et al. Aprendizagem baseada em equipes: da teoria à prática. Medicina, Ribeirão Preto, v. 47, n. 3, p. 293-300, 2014. 
CASTELLS, M. A sociedade em rede. São Paulo: Paz e Terra, 2000. v. 1.

ESCOLA MUNICIPAL DE ENSINO FUNDAMENTAL INTENDENTE MANOEL RIBAS. Projeto Político Pedagógico. Santa Maria: EMEFIMR, 2018. 20 p.

FERREIRA, G. R. M.; RIBEIRO, A. C. R.; BEHAR, P. A. Redes Sociais em um Ambiente Virtual de Aprendizagem: uma análise a partir da ferramenta Mapa Social. Revista Renote, Porto Alegre, v. 15, n. 2, 2017.

FREIRE, P. Pedagogia do oprimido. 50. ed. rev. e atual. Rio de Janeiro: Paz e Terra, 2011.

GIL, A. C. Como elaborar projetos de pesquisa. 4. ed. São Paulo: Atlas, 2008.

KENSKI, V. M. Educação e comunicação: interconexões e convergências. Educação \& Sociedade, Campinas, v. 29, n. 104, p. 647-665, out. 2008.

LIMA, L.; LOUREIRO, R. C.; TELES, G. Interdisciplinaridade e tecnologias digitais na transformação da compreensão de docência. Revista lberoamericana de Tecnología en Educación y Educación en Tecnología, La Plata, n. 20, p. 16-27, 2017.

MARANDINO, M.; SELLES, S. E.; FERREIRA, M. F. Ensino de Biologia: histórias e práticas em diferentes espaços educativos. São Paulo: Cortez, 2009.

MOREIRA, J. A. Reconfigurando ecossistemas digitais de aprendizagens com tecnologias audiovisuais. EmRede - Revista de Educação a Distância, Porto Alegre, v. 5, n. 1, p. 5-15, 2018.

NELSON, T. O.; NARENS, L. Why investigate metacognition?. In: Metcalfe, J.; Shimamura, A. P. (Eds.). Metacognition: knowing about knowing. Cambridge: MIT Press, 1994. p. 1-25.

SCHLOTTFELDT, L. M. Oficinas temáticas e o ensino de ciências da natureza em uma escola do campo do município de Santa Maria, Rio Grande do Sul. 2018. 90 f. Dissertação (Programa de Pós-Graduação em Ensino de Ciências e Matemática) - Universidade Franciscana, Santa Maria, 2018. 
SILVA, I. N. et al. Inclusão digital em escolas públicas através de tecnologias inovadoras de baixo custo no ensino de disciplinas stem. Revista Renote, Porto Alegre, v. 15, n. 2, 2017.

SILVA, P. F.; TAROUCO, L. M. R. A construção do pensamento formal pelo adolescente em ambiente virtual. Revista Renote, Porto Alegre, v. 16, n. 1, 2018. 


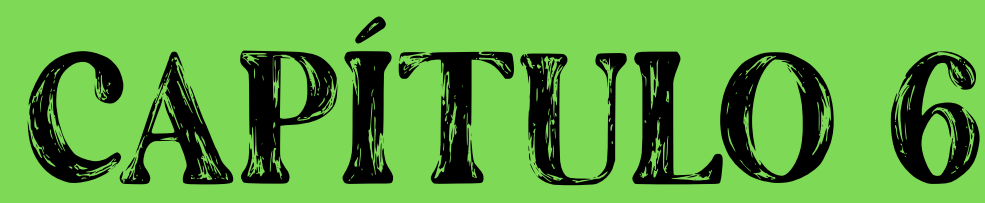

\section{ENSINO REMOTO: GOOGLE EARTH COMO POSSIBILIDADE METODOLÓGICA PARA O ENSINO DE GEOGRAFIA}

Cícero Antonio Jatanael da Silva Tavares 


\section{INTRODUÇÃO}

O ensino de Geografia é, sem dúvidas, indispensável no que tange a formação discente. É através dessa disciplina onde os estudantes perpassam a ter uma melhor capacidade de leitura do mundo nas mais diversas escalas, onde os conhecimentos abordados em aula partem do local e se expandem em direção ao global.

Assim, lecionar os conteúdos dessa disciplinar requer uma aproximação com os estudantes, para viabilizar a participação dos alunos quanto as dúvidas que vão surgindo na aula. Além disso, em alguns momentos, é oportuno que sejam realizadas aulas de campo no sentido de mostrar a Geografia no cotidiano dos alunos.

No entanto, este período de pandemia do SARS-CoV-2, o Novo Coronavírus, tem impactado diretamente no ensino, uma vez que em diversas escolas às aulas ainda não retornaram totalmente ao presencial, funcionando de forma híbrida. Assim, os professores precisam estar aptos a se reinventar e buscar alternativas metodológicas para a mediação dos conteúdos de Geografia.

Nesse sentido, este trabalho surge com o objetivo de apresentar a possiblidade de uso do Google Earth como recurso didático para o ensino de Geografia. Tal temática surge como uma forma de trazer uma metodologia que contribua para a aprendizagem discente, mesmo que o ensino seja realizado totalmente remoto ou híbrido. Assim, destaca-se, sobretudo, o fato de que para colocar essa metodologia em prática requer somente saber manejar essa geotecnologia.

Google Earth é uma geotecnologia que surgiu com o propósito de servir como fonte de dados e ser utilizada para diversos fins a qual não está incluso o ambiente escolar. Portanto, tem um caráter paradidático. O que se pretende aqui é apresentar a possibilidade de conversão desse programa para um recurso como finalidade didática. 
Dessa forma, perante o contexto pandêmico que vivemos, o que impõe ao quadro docente imensas barreiras no ensino das disciplinas, em especial da Geografia, admite-se uma viabilidade em abordar sobre este recurso como uma alternativa viável e eficaz no processo de ensino e aprendizagem.

Mediante às discussões aqui apresentadas, pode-se reafirmar a possibilidade de aplicação do Google Earth no ensino de Geografia, como forma de reverter as dificuldades impostas pela pandemia no tocante ao distanciamento social. Assim, não restam dúvidas quanto à necessidade de se discutir este tema.

\section{MATERIAIS E MÉTODOS}

Este trabalho contempla uma natureza bibliográfica e tem um caráter expositivo. Isso se dá em razão da necessidade de ter sido desenvolvidas leituras que proporcionasse a reflexão sobre a possibilidade de utilizar as geotecnologias de diversas formas. Assim, tem-se como foco central a apresentação da metodologia de ensino a partir do uso do Google Earth.

É preciso ser ressaltado que este manuscrito se trata da apresentação de uma possibilidade metodológica para o ensino de Geografia. Portanto, ainda não houve a prática em sala de aula. Assim, aos professores interessados, fica aqui essa metodologia como sugestão, uma vez que se expressa como uma alternativa viável e eficaz em momentos de aula remota.

Desse modo, como suporte para perceber a viabilidade de aplicação do Google Earth no ensino de Geografia, teve-se os seguintes autores: Lima (2012), Sousa e Albuquerque (2017) e Tavares (2021), que contribuem com discussões a respeito das geotecnologias aplicadas ao ensino, além de outras abordagens pertinentes ao que está proposto neste manuscrito.

Assim, como forma de demonstrar como sucederá essa prática metodológica perante ao professor, é dado um exemplo hipotético de aula remota na cidade de Juazeiro do Norte/CE, em que se faz necessário a utilização dos seguintes recursos: computador, internet, Google Earth e Google Meet. Quanto aos alunos, 
faz-se útil o acesso a um aparelho com internet para acompanhar e participar da aula.

No tocante ao meio de avaliação para comprovar a efetividade dessa alternativa metodológica frente a aprendizagem discente, é plausível aderir ao modelo avaliativo que melhor corresponder a turma em que se realiza a atividade. Deixa-se aqui como sugestão a análise na participação dos alunos durante a exposição do conteúdo no Google Meet.

\section{GOOGLE EARTH APLICADO AO ENSINO DE GEOGRAFIA: DA TEORIA A PRÁTICA}

O ensino de Geografia surge nos currículos escolares como um importante instrumento no tocante a formação de um discente crítico, participativo e que esteja apto a analisar o espaço vivido com um olhar geográfico.

Evidentemente, na escola, não se pretende formar "minigeógrafos", como se esses estudantes devessem sair desse ambiente escolar especializados nos conteúdos geográficos. Porém, almeja-se que compreendam o mínimo que se espera de um aluno ao final de cada ano letivo.

Assim, servindo também como um parâmetro para a identificação da capacidade de aprendizagem discente, surge a Base Nacional Comum Curricular (BNCC), documento onde está exposto não somente o currículo base para cada disciplina escolar, mas também as habilidades e competências que o aluno deve apreender.

Para se chegar aos objetivos ora supracitados, perpassa-se uma série de situações sob a qual se exige uma responsabilidade em via de mão dupla entre aluno e professor, além de participação do governo mediante a oferta de uma infraestrutura escolar adequada para a realização da aula, no caso das escolas públicas.

Assim, observa-se que é um desafio para ambas as partes quanto aos caminhos para a aprendizagem significativa. São habilidades e competências que, 
quando observadas perante a modalidade remota, onde se tem uma piora na comunicação entre professor-aluno, torna-as ainda mais difíceis de se alcançar.

Antes de tudo, é preciso enfatizar também que, tal como já é conhecimento entre aqueles que compõe a comunidade escolar, a legislação brasileira não permite que a educação básica no Brasil ocorra em modalidade remota, independentemente de serem assíncronas ou síncronas.

No entanto, como enfatizado anteriormente, o mundo adentrou em um contexto de pandemia e obrigou aos conselhos competentes a repensar sobre a situação. Assim, mediante a Portaria $n^{\circ}$ 343, de 17 de março de 2020, publicado no Diário Oficial da União, iniciou-se uma série de atualizações legislativas a respeito da permissão para que o ensino da educação do país ocorresse em modalidade remota.

Nesse sentido, essa nova forma de vivenciar o cotidiano escolar colocou em evidência a preparação da comunidade escolar no tocante ao uso das tecnologias. Observadas às adversidades impostas pelo contexto pandêmico, faz-se necessário uma reinvenção no processo de ensino e aprendizagem, sobretudo por parte do professor.

Evidentemente, é uma adversidade também ao discente que, por vezes, pode nem mesmo possuir internet em sua residência, para ter acesso às aulas nessa modalidade de ensino. Mas, ainda que se tenha, faz-se preciso ainda que o professor esteja apto a manejar esses recursos tecnológicos.

Dessa maneira, pode-se pautar a importância da formação docente continuada, como forma de manter o professor atualizado frente às possibilidades de mediar exitosamente às suas aulas no ensino remoto.

Assim, por formação continuada, Wengzynski e Tozetto (2012, p. 3) afirmam que é:

Entendida como perspectiva de mudança das práticas no âmbito dos docentes e da escola possibilita a experimentação do novo, do diferente a partir das experiências profissionais que ocorrem neste espaço e tempo 
orientando um processo constante de mudança e intervenção na realidade em que se insere e predomina esta formação.

Além disso, essa formação continuada se faz útil para que o professor acompanhe os novos tempos, sobretudo tecnológico, a qual os alunos costumam estar inseridos. Sob esse ângulo, Tavares (2021, p. 185) afirma que:

É percebido a necessidade desse profissional exercer esse aperfeiçoamento em razão do fator das mudanças constantes que os estudantes percorrem. Nesse sentido, é possível afirmar que o perfil dos alunos de 20 (vinte) anos atrás não seja o mesmo dos dias atuais, isso por conta das transformações ocorridas na sociedade em geral ao longo dos anos e que interfere diretamente nas instituições de ensino. De tal modo, pode-se concluir também que as características discentes de posteriores 20 (vinte) anos não será idêntica as que se encontram contemporaneamente.

Nesse próprio contexto de pandemia, mediante aulas remotas de outros professores, palestras em eventos ou outras formas de exposição virtual, foi possível notar as dificuldades existentes em manejar a tecnologia necessária para ocorrer a comunicação nessa modalidade remota.

Tal situação acontece, inclusive, de forma mais acentuadas, com profissionais formados em época distintas ao avanço de tecnologias como o Google Meet, meio de comunicação mais utilizado ao longo das atividades escolares e acadêmicas nesse momento. Assim, no seu período de formação inicial, inexistia a possibilidade de se capacitar no tocante ao uso das tecnologias aplicadas ao ensino.

Portanto, a formação docente continuada se estabelece como um importante meio para que o professor consiga se manter atualizado frente às mudanças no perfil dos alunos, bem como para eventualidades atípicas como o contexto de pandemia, que impôs o uso desse recurso como única alternativa plausível para essa ocasião.

Ampliando a discussão, é possível afirmar que, quando se está preparado para mediar aulas com metodologias alternativas, o professor tende a desenvol- 
ver aulas com melhores resultados quanto a aprendizagem dos discentes. Como possiblidade, tem-se o uso das geotecnologias.

Segundo Menezes et al. (2017, p. 59):

As geotecnologias (ou tecnologias espaciais), conhecidas também, segundo alguns autores, por geoprocessamento, são consideradas o conjunto de técnicas que tem como função coletar, processar, analisar e oferecer informações com referência geográfica (ou espacial). São exemplos de tecnologias espaciais os sistemas de informações geográficas, a cartografia digital, o sensoriamento remoto e o sistema de posicionamento global. Elas podem ser utilizadas para criar informações que levam a manipulação e consequentemente a análise do espaço geográfico, realizada por meio das novas tecnologias.

Aplicando ao ensino de Geografia, algumas dessas ferramentas de dados pode auxiliar o professor no ensino dos conteúdos geográficos. Dessa forma, dá-se ênfase aqui aos Google Earth.

Nas palavras de Lima (2012, p, 18):

O programa Earth Viewer foi desenvolvido pela Keyhole, Inc, uma companhia adquirida pela empresa norte americana Google em 2004. O produto, renomeado de Google Earth ${ }^{\mathrm{TM}}$ (GE), tornou-se em 2005, disponível para uso em computadores pessoais. Apesar de existirem programas similares, como o seu pricipal concorrente, o Microsoft's BingMaps (Virtual Earth), nenhum é comparado ao GE em popularidade.

A opção por essa geotecnologia surge, dentre diversas razões, pela possibilidade metodológica e por ser um programa amplamente reconhecido por professores e alunos, embora isso por si só não garanta um manejo adequado dessa geotecnologia.

Nesse sentido, Sousa e Albuquerque (2017, p. 100) apontam que:

Um diferencial significativo do Google Earth é a tridimensionalidade. Os lugares podem ser vistos de qualquer ângulo. Esse recurso pode contribuir para um aprendizado mais significativo de alguns temas da Geografia, a exemplo dos estudos geomorfológicos. Por sua vez, os alunos podem por meio da observação das paisagens retratadas, fazer analogias com seu entorno, ou seja, com a realidade vivida. 
Assim, enquanto aplicada ao ensino de Geografia, esse recurso contribui no desenvolvendo de aulas sobre uma série de conteúdos de cunho geográfico. De tal modo, quando utilizadas outras ferramentas instaladas no Google Earth, esse horizonte se amplia. Assim é o caso do uso do Google Street View.

Esse recurso supracitado consiste em proporcionar a possibilidade de qualquer interessado em trafegar virtualmente por ruas e avenidas de praticamente qualquer cidade do mundo. Aplicada ao ensino de Geografia, o professor pode realizar aulas de campo virtuais com alunos e, mediante a essa atividade, mediar conteúdos interligados a urbanização da localidade.

Essa aula de campo por uma cidade pode, preferencialmente, ser a própria onde o aluno vive. Assim, a partir dessa aula, esse discente pode desenvolver a habilidade de compreender parte dos fatores urbanos com um olhar geográfico.

Ampliando esta discussão, visando expor a prática dessa metodologia de ensino, destaca-se que se faz necessário a utilização de um programa que permita a realização da aula, como Google Meet. Nesse programa é realizado o compartilhamento de tela para que possa ser reproduzido o conteúdo do Google Earth, momento em que o professor realiza a mediação do conteúdo.

Como forma de esclarecer o desenvolvimento da metodologia, utiliza-se aqui o município de Juazeiro do Norte, no Estado do Ceará, como exemplo prático no uso do Google Earth.

Conforme apresentado na Figura 1, logo abaixo, é possível identificar como seria essa prática de ensino. 
Figura 1: Praça do Giradouro, em Juazeiro do Norte/CE.

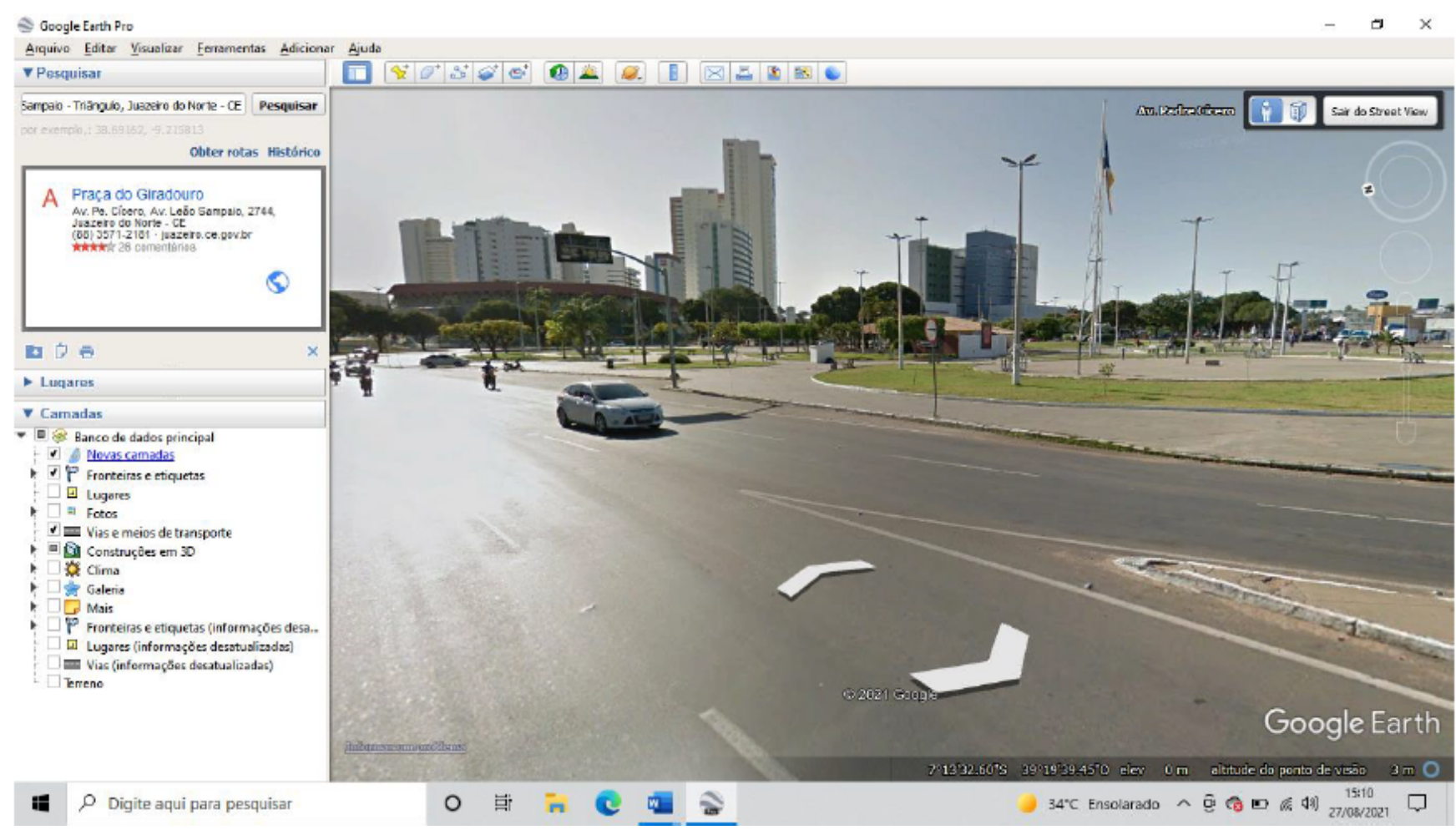

Fonte: Google Earth, 2021.

Nessa supracitada ocasião, é concebível haver uma aula referente a temática pertinente a fluxo de atividades que ocorrem nesse espaço urbano ao interligar a geografia escolar. Assim, é oportuno caminhar virtualmente por essa avenida e utilizar esse recurso na modalidade remota de ensino.

Para que o professor consiga percorrer por todo o trajeto, necessita somente clicar constantemente em uma dessas duas setas expostas na figura. Assim, conseguirá ter uma visão de outras partes da localidade.

A Praça do Giradouro, exposta nessa figura, é um dos principais espaços públicos de Juazeiro do Norte, sendo um local apropriado tanto para o lazer quanto para a prática esportiva, como a caminhada. Além disso, está situada em uma área em que interliga parte da cidade a um dos principais centros econômicos dessa urbe, o Cariri Garden Shopping.

Destaca-se também a presença de outros importantes equipamentos urbanos que estão situados no entorno, como um campus de um centro universitário 
e um outro de uma universidade pública, além da presença de um hospital e da rodoviária municipal, bem como de outros equipamentos de menor porte.

Assim, é possível averiguar que esse local é condicionado a uma série de aspectos possíveis se discutir à luz da Geografia, viabilizando a aula de campo nesse espaço em questão.

Dessa forma, outros conteúdos podem ser viáveis mediante o uso do Google Earth, como a análise temporal da urbanização da cidade, expondo os agentes, processos e fatores condicionantes para tal reprodução do espaço, conforme exposto na Figura 2.

Figura 2: Espaço urbano de Juazeiro do Norte/CE, em 1985.

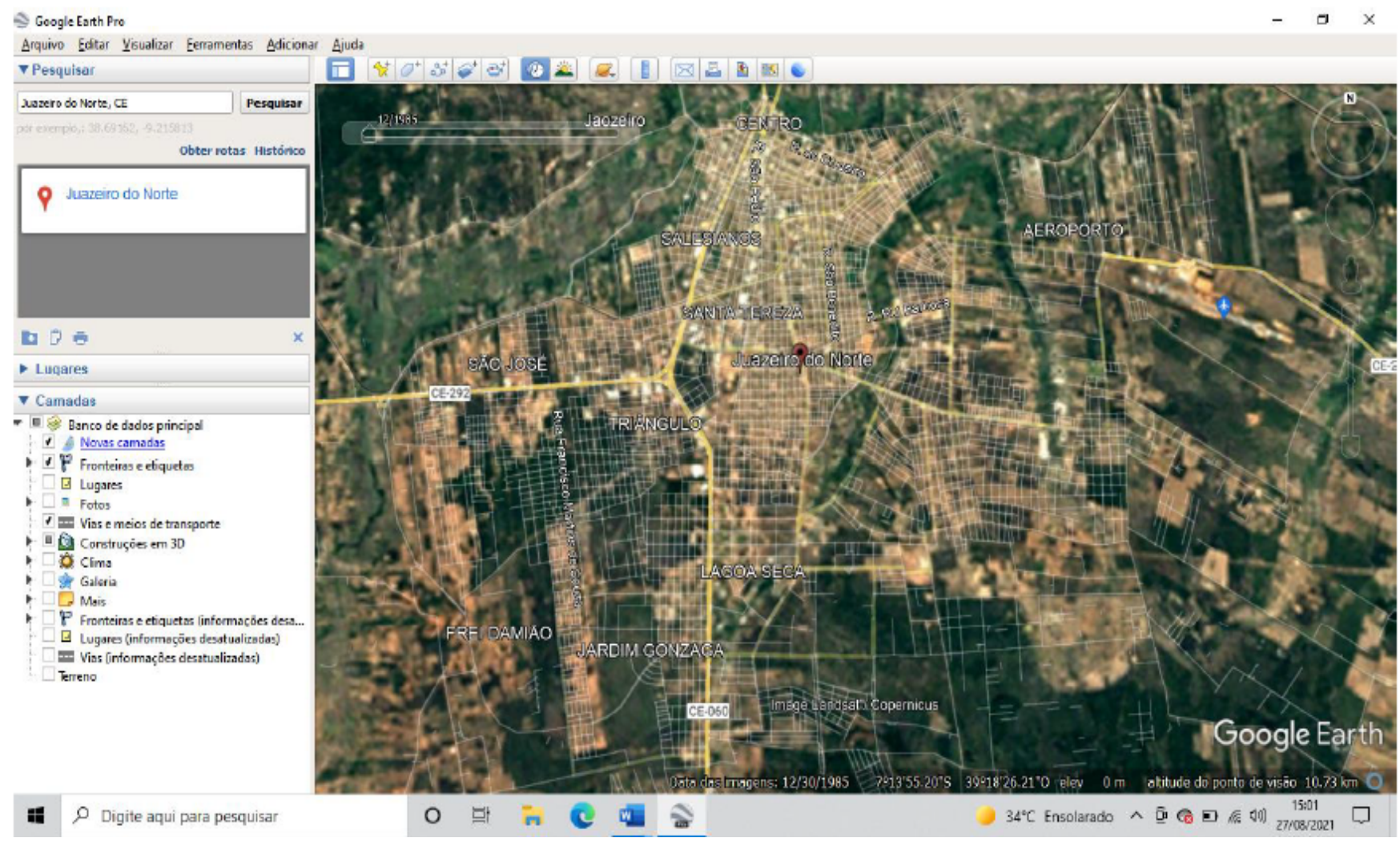

Fonte: Google Earth, 2021.

Nessa figura, pode-se observar uma parcela do espaço urbano de Juazeiro do Norte no ano de 1985. De lá pra cá, ocorreram diversas mudanças socioespaciais, que colocaram o município como um dos maiores do estado no quesito taxa de urbanização, ao alcançar um território como 96,07\% urbanizado (IPECE, 2011). 
Mas, que fatores condicionantes estão por traz disso? Quais são os impactos socioambientais que isso desencadeou na vida da população? Qual a relação de influência que essa urbe exercer para os municípios do entorno? Como isso interliga a maiores escalas, como a estadual e nacional? Essas são algumas questões que o professor pode refletir junto aos alunos no decorrer da atividade.

Além disso, nessa ocasião proposta para aula, quando adicionada uma figura de anos posteriores, além da questão urbana, é plausível ainda analisar as mudanças ambientais, ao identificar que as áreas verdes do município vão sendo substituídas por construções civis, conforme vemos na Figura 3.

Figura 3: Espaço urbano de Juazeiro do Norte/CE, em 2021.

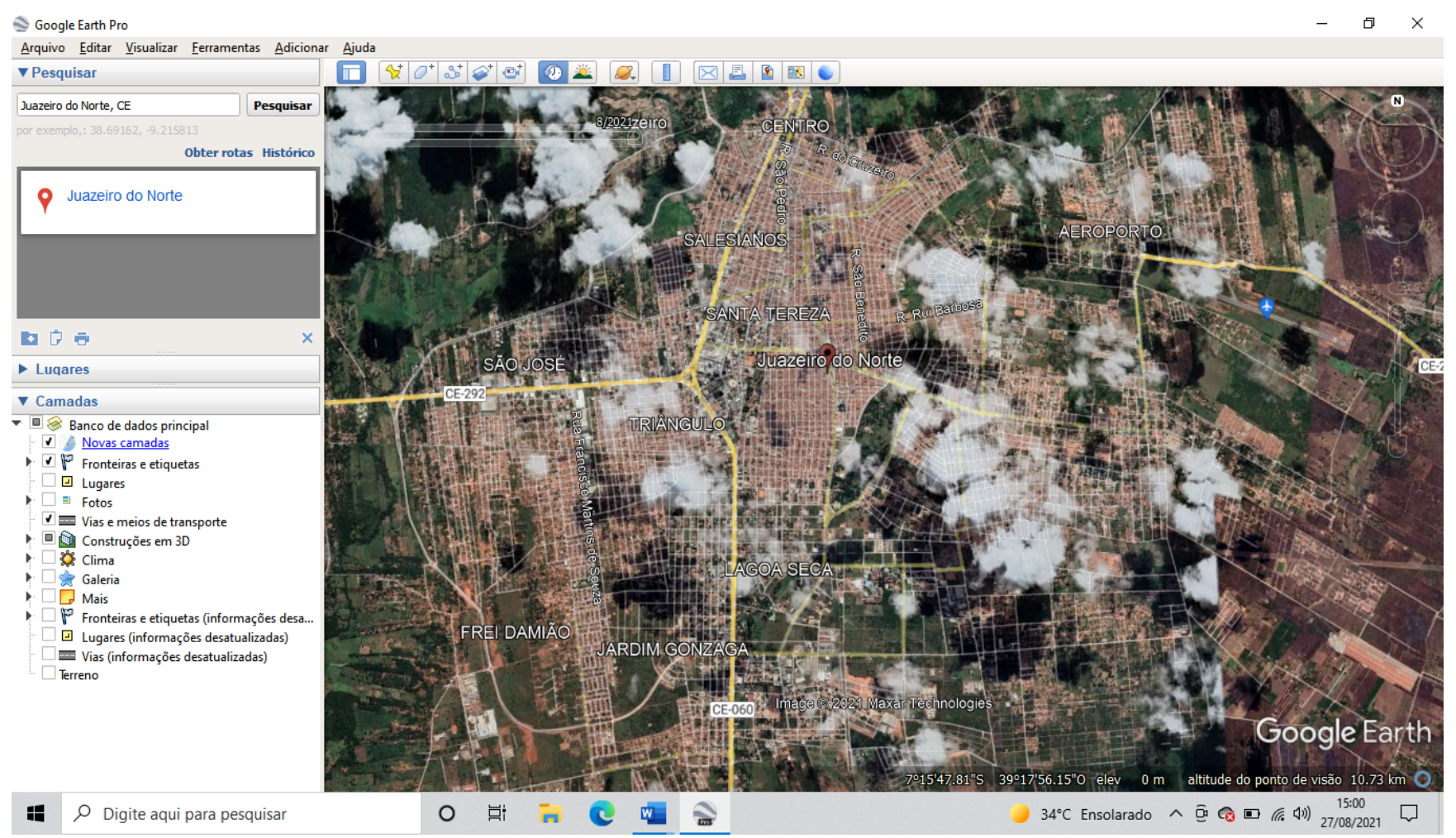

Fonte: Google Earth, 2021.

Por se tratar de uma área possivelmente conhecida e frequentada por uma parcela dos estudantes envolvidos na aula, levando em consideração que o município aderido para a atividade seja aquele pertencente ao aluno, é presumível que se constate uma significativa participação desses sujeitos na abordagem do conteúdo. 
De certo modo, é presumível que, em um momento inicial, antes da aula, os alunos poderão não perceber a existência da geografia no espaço onde vivem, ocupam e consomem. Mas, com a aula realizada a partir do espaço vivido por eles, passarão a ter um olhar geográfico sobre a localidade.

Dessa forma, é concebível romper ainda com o paradigma de uma geografia tradicional, onde os conteúdos, por vezes, estão desvinculados do cotidiano discente. Mais do que isso, é benéfico fazer percebê-los a importância da geografia para a compreensão do espaço em seu cotidiano.

Portanto, vê-se que há a possibilidade de inserir o Google Earth no ensino de Geografia. Evidentemente, uma série de outros conteúdos podem ser utilizados mediante essa tecnologia. Além disso, pode ser realizada mediante qualquer município, restando somente que o professor faça as devidas adaptações no enfoque do conteúdo.

Nessa prática de ensino, relembrando as competências e habilidades propostas pela BNCC, acredita-se ainda que seja plausível identificar que os alunos contemplarão aos objetivos ora propostos para o conteúdo, ao compreender a mediação de forma participativa, lúdica e propositiva junto a aplicação do Google Earth como possibilidade de ensino da disciplina de Geografia na modalidade remota.

\section{CONCLUSÃO}

De fato, o ensino de geografia se faz importante para que o discente possa fazer leituras sobre o mundo. É evidente também que o ensino, ainda que em sua modalidade presencial, sempre esteve permeada por uma série de barreiras para se ter resultados positivos na aprendizagem discente.

Dessa forma, nessa modalidade de ensino remoto aqui observada, vê-se que às adversidades se ampliam, fazendo com que os professores e alunos se reinventem nesse período atípico. 
Assim, podemos destacar as contribuições da aplicação do Google Earth para o ensino de Geografia, uma vez que essa mediação dos conteúdos pode ser realizada virtualmente e a discussão do conteúdo em si não se torna tão prejudicada quando comparada a modalidade presencial.

Evidentemente, a aprendizagem e as discussões seriam ainda mais positivas se fossem realizadas em aulas presenciais. Mas, diante desse período emergencial de ensino remoto, esse recurso que ora é apresentado se estabelece como uma alternativa metodológica viável e significativa.

\section{REFERENCIAS}

BRASIL. Ministério da Educação. Base Nacional Comum Curricular. Brasília, 2018.

BRASIL. Portaria $n^{\circ}$ 343, de 17 de março de 2020. Dispõe sobre a substituição das aulas presenciais por aulas em meios digitais enquanto durar a situação de pandemia do Novo Coronavírus - COVID-19. Diário Oficial da União, Brasília, 2020. Disponível em: http://www.planalto.gov.br/CCIVIL_03/Portaria/PRT/Portaria\%20n\%C2\%BA\%20343-20-mec.htm Acesso em: 22/08/2021.

IPECE, Instituto de Pesquisa e Estratégia Econômica do Ceará. Perfil básico municipal 2011: Juazeiro do Norte. Fortaleza, 2011. Disponível em: https://www. ipece.ce.gov.br/wp-content/uploads/sites/45/2018/09/Juazeiro_do_Norte_2011. pdf Acesso em: 21/08/2021.

LIMA, Raphael Nunes de Souza. Google Earth aplicado a pesquisa e ensino da Geomorfologia. Revista de Ensino de Geografia, Uberlândia, v. 3, n. 5, p. 1730, 2012.

MENEZES, Sady Martins da Costa de; RIBEIRO, Carlos Antonio Alvares Soares; LIMA, Cleverson Alves de; SOUZA, Maria Odete Alves de. Geotecnologias aplicadas à gestão ambiental. Diversidade e Gestão, vol. 1, número 1, pág. 5769, 2017. Disponível em: http://www.itr.ufrrj.br/diversidadeegestao/wp-content/ uploads/2017/07/05-Geotecnologias_Sady_revisado_20_05_17.pdf Acesso em: 21/08/2021. 
SOUSA, Luciano Mascarenhas da Silva; ALBURQUERQUE, Emanuel Lindemberg Silva. Google Earth e ensino de cartografia: um olhar para as novas geotecnologias na escola Santo Afonso Rodriguez, município de Teresina, Estado do Piauí. Revista Geosaberes, Fortaleza, v. 8, nº 15, p. 94-104. 2017.

TAVARES, Cícero Antonio Jatanael Da Silva. Formação continuada docente: adversidades e contribuições. In: SOUZA, Ednilson Sergio Ramalho de. (Org.). Pesquisas em temas de ciências da educação. $1^{\text {a }}$ ed. Belém: RFB Editora, 2021, v. 1, p. 183-196. Disponível em: https://d545c17b-f3d5-41c9-bf28-a48acf4c19a8. filesusr.com/ugd/baca0d_5e326256a6fc4424acfe2f068512aec6.pdf Acesso em: $21 / 08 / 2021$.

WENGZYNSKI, Cristiane Daniele; TOZETTO, Susana Soares. A formação continuada face as suas contribuições para a docência. In: Seminário de Pesquisa do PPE, 2012. Anais... Maringá, 2012. Disponível em: http://www.ppe.uem.br/publicacoes/seminario_ppe_2012/trabalhos/po/po_008.pdf Acesso em: 21/08/2021. 


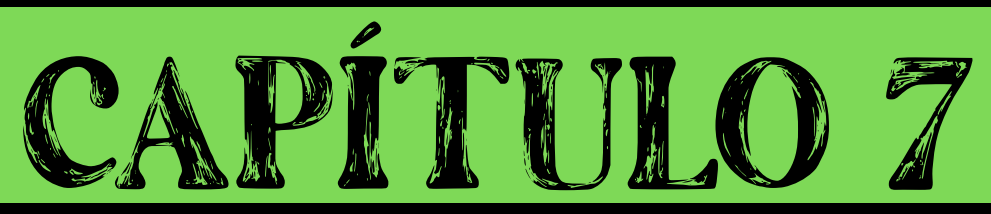

\section{UTILIZAÇÃO DE IMAGENS NA APRENDIZAGEM}

\section{BASEADA EM PROBLEMAS} (ABP) NA CONCEPÇÃO DE PÓS-GRADUANDOS

Luana Ehle Joras Darlize Déglan Borges Beulck Bender 


\section{INTRODUÇÃO}

O SARS-COV 2, comumente conhecido como coronavírus, surgiu na China no final de 2019 e se tornou uma Pandemia em 2020, perdurando até os dias de hoje, provocando grandes mudanças no dia a dia das pessoas. Assim, na área da Educação, as aulas passaram a funcionar remotamente, o que foi possível graças à tecnologia digital e ao empenho dos professores. Portanto, reinventar-se com as ferramentas e dispositivos tecnológicos foi uma alternativa inovadora para a manutenção de relações no ambiente educacional, visto que estudantes e professores precisam dar continuidade ao processo de ensino e aprendizagem (ARRUDA e SIQUEIRA, 2021).

Deste modo, no atual cenário educacional tem-se buscado o acesso por parte dos docentes acerca do desenvolvimento de metodologias ativas na aprendizagem (MAA) e o uso de novas ferramentas pedagógicas das quais se acredita que por meio delas o educar possa se tornar mais eficiente e atuante. Neste contexto, as Tecnologias da Informação e Comunicação (TICs) que aparecem diariamente no cotidiano das pessoas têm provocado mudanças no entretenimento, no contato pessoal e no aprendizado. Os cursos a distância utilizam esses recursos através de Ambientes Virtuais de Aprendizagem (DOS SANTOS et al., 2021).

Esses ambientes permitem a utilização de metodologias ativas centradas no educando, sendo o professor considerado um mediador ou facilitador do processo de aprendizagem do aluno, não sendo mais visto como o único meio de conhecimento em sala de aula (PEREIRA, 2012; LOVATO et al., 2018).

Pesquisadores relatam que o uso de metodologias ativas já vem sendo aplicado em sala de aula para qualificar o processo de ensino-aprendizagem há algum tempo. Porém, devido a vários aspectos pessoais e/ou profissionais da própria formação, alguns profissionais ainda resistem em utilizá-las (MARTINS, 2018). 
Conforme Bondioli, Vianna e Salgado (2019), o educador que faz uso das metodologias ativas, consegue despertar nos estudantes o interesse em participar de suas aulas, de forma que é possível desenvolver vários aspectos importantes do conhecimento, e com a prática o educando passa a construir objetos, manipular e realizar experimentos, podendo explorar os conhecimentos adquiridos de forma mais ampla.

Na percepção de alguns autores (DO NASCIMENTO et al., 2018) as metodologias ativas mais conhecidas são: Sala de aula invertida, Aprendizagem baseada em problemas (ABP) ou Problem based learning ( $P B L$ ), Fórum de discussão virtual, Aprendizagem cooperativa, e Aprendizagem baseada em projetos. Em contrapartida, de acordo com os autores mencionados acima, as menos comuns são: Educomídia, Narrativas digitais, Convergência digital, Storytelling, gamificação e simulação. Na ABP, tem-se buscado alternativas para auxiliar os professores a elaborar problemas de aprendizagem, entre essas opções estão o uso de imagens (BENDER et al., 2021).

Segundo Nikolaveja e Scott (2011), nos dias atuais, embora as sociedades ocidentais contemporâneas sejam cada vez mais visuais, mesmo no que diz respeito à relação entre texto e imagem, os estudos literários geralmente negligenciam esse aspecto visual ou tratam a imagem como secundária. De acordo com as autoras, isso ocorre porque a imagem em geral é vista como uma simples ilustração de um texto escrito, hierarquizando a relação entre imagem e texto.

Diante do contexto apresentado, verificamos que a metodologia ABP é composta por três pilares: o problema, o educando e o educador (SAVERY, 2006). Neste caso, focamos no problema, pois ele pode ser considerado uma ferramenta para integrar as discussões teóricas e práticas à realidade educacional.

Deste modo, este estudo tem o seguinte problema de pesquisa: Quais são as concepções de Pós-Graduandos sobre a utilização de imagens na Abordagem Baseada em Problemas? Tendo como objetivo ajudar estudantes e professores a usar imagens para desenvolver situações-problema na ABP. 


\section{METODOLOGIA}

Esta pesquisa caracteriza-se por uma abordagem qualitativa do tipo descritiva e exploratória. Descritiva, pois se refere a expor as características da população pesquisada para analisar, registrar e descobrir a frequência e relação dos dados obtidos e, exploratória porque proporciona maior familiaridade com o problema para torná-lo mais claro e fácil de entender (GIL, 2019).

Durante a segunda edição do evento "Ciência em Ação: Educar é Transformar", foi realizada uma oficina virtual oferecida a alunos de graduação e pós-graduação, bem como professores universitários e de educação básica. Ciência em Ação é um evento presencial que ocorre desde 2018 e originou-se a partir dos representantes discentes do curso de Pós-Graduação de uma Universidade Federal do Sul do Brasil.

Participaram da oficina 25 sujeitos, dos quais $4 \%$ representavam os educadores dos anos iniciais, $12 \%$ educadores do ensino médio, $20 \%$ educadores dos anos finais e $64 \%$ estudantes apenas. Todos os sujeitos eram alunos de pós-graduação de uma Universidade Federal do Sul do Brasil. Destes, 72\% eram mulheres e $28 \%$ homens.

A idade dos participantes variou entre 18 e 40 anos, sendo que 6 deles tinham mais de 40 anos. Destes, 32\% mencionaram ter a idade entre 26 e 30 anos, $32 \%$ entre 15 e 18 anos, 24\% entre 40 anos e 12\% entre 31 e 39 anos. Os campos de atividade dos sujeitos da pesquisa são: $80 \%$ ciências naturais ( $46 \%$ ciências, $30 \%$ química e $4 \%$ física), $8 \%$ ciências humanas (geografia), $8 \%$ ciências da saúde (educação física e enfermagem) e 4\% EJA e intervenções de comunicação.

A coleta de dados foi realizada por meio de questionários online (Formulários Google) aplicados antes e após a oficina, incluindo dez questões em cada. No questionário inicial estavam contempladas as seguintes questões abertas: 1) Qual é o seu nome?; 5) Área de atuação; 10) O que você espera desta oficina?. 
As questões fechadas foram as seguintes: 2) Qual é a sua idade? a) 1825 anos, b) 26-30 anos, c) 31-39 anos, d) >40 anos; 3) Sexo? a) Feminino, b) Masculino, c) Outro; 4) Profissão? a) Estudantes, b) Professor de Educação Infantil, c) Professor de Anos Iniciais, d) Professor de Anos Finais, e) Professor de Ensino Médio, f) Professor de Ensino Superior; 6) Sobre as metodologias ativas em sala de aula (de modo geral) a) Uso atualmente, b) Já usei, c) Conheço, mas nunca usei, d) Desconheço; 7) Sobre a utilização da Aprendizagem Baseada em Problemas (Problem Based Learning- PBL) a) Uso atualmente, b) Já usei, c) Conheço, mas nunca usei, d) Desconheço; 8) Você acredita que a aplicação de metodologias ativas em sala de aula contribui/estimula o aprendizado do aluno?; 9) Você já utilizou imagens durante o desenvolvimento de metodologias ativas em sala de aula? a) Sim, b) Não.

Já no questionário final, foram aplicadas cinco perguntas abertas e cinco fechadas. As questões abertas foram as seguintes: 1) Qual seu nome?; 2) Quais benefícios você pode perceber com a metodologia proposta nesta oficina?; 7) Com que finalidade você utiliza imagens em suas aulas? Quantas imagens costuma usar?; 8) Quais os critérios que você utiliza na escolha de imagens para aplicação em sala de aula?; 9) Quais os procedimentos/cuidados que você estabelece ao usar imagens em suas aulas?

As questões fechadas do questionário final foram as seguintes: 3) Percepção da sua aprendizagem com a oficina? a) Aprendi muito, b) Aprendi pouco; 4) Você pretende trabalhar ABP/PBL com seus alunos? a) Já uso atualmente, b) Quero voltar a usar, c) Sim, d) Não, e) Talvez; 5) Após a leitura do material disponibilizado antes da oficina, sobre os variados tipos de metodologias ativas que podem ser desenvolvidas em sala de aula, você se sentiu motivado(a) em desenvolvê-las em sua prática docente? a) Sim, b) Não, c) Talvez; 6) A utilização da imagem durante a oficina facilitou a construção de um problema? a) Sim, b) Não; 10) O que a oficina pode contribuir com sua formação inicial ou continuada? a) Vou começar a utilizar as metodologias ativas em aula, b) Preciso estudar mais, antes de implementá-las em sala de aula, c) ou continuar utilizando, d) outro. 
Destaca-se que dos 25 participantes no dia da oficina, apenas 13 responderam ao questionário inicial e final. Assim, na sessão "Resultados e discussão" apenas serão mencionadas as respostas das pessoas que responderam aos questionários inicial e final, ou seja, dos 13 participantes. Deste modo, os participantes foram identificados como P1, P2, P3, etc. de modo a garantir seu anonimato.

Para explorar os dados, utilizou-se a Análise de Conteúdo (BARDIN, 2011). Essa análise é dividida em três etapas: i) pré análise, ii) exploração do material e, iii) tratamento dos resultados obtidos e interpretação. Desta forma, este capítulo apresenta as concepções dos participantes da oficina sobre a utilização de imagens na $A B P$.

\section{RESULTADOS E DISCUSSÃO}

As MAA podem ser importantes para estimular o interesse dos alunos, porém o mais importante é que, mesmo que seja uma "inovação" a utilização de imagens em $A B P$, também se faz necessária essa reflexão sobre o comportamento dos atuais e futuros professores sobre o tema. Deste modo, através da oficina e das trocas de ideias entre pares, observou-se que a maioria dos participantes (46\%) já havia utilizado as MAA em suas aulas.

O uso de MAA tem sido considerado como uma abordagem que direciona a educação e permite que os alunos desenvolvam conhecimentos e habilidades por meio de descobertas, a participação e a interação (PUCINELLI; KASSAB; RAMOS, 2021). Em estudos bibliométricos sobre a utilização de MAA no ensino superior, esses mesmos autores relatam que a sala de aula invertida tem sido a metodologia mais procurada e, por conseguinte, a metodologia mais explorada pelos estudos que analisaram.

A sala de aula invertida é uma estratégia de aprendizagem combinada com objetivos. Esta metodologia busca melhorar o envolvimento e os resultados dos alunos através de um número menor de aulas expositivas e com mais envolvimento, permitindo que os alunos participem do conteúdo e aproveitem ao máximo o tempo e o conhecimento dos professores (SILVA, 2020). 
A autora ainda salienta que na sala de aula invertida, a prática está concentrada em $90 \%$ da aula e $10 \%$ no conteúdo. Deste modo, o professor será um intermediário do conhecimento, proporcionando aos alunos possibilidades criativas e preparando-os para tornarem-se pesquisadores no futuro.

Descobriu-se também, que $39 \%$ dos participantes da oficina conhecem as MAA, porém nunca utilizaram em sala de aula, enquanto que $15 \%$ usam atualmente. Este último dado é considerado baixo se comparar com os $36 \%$ dos relatos que atualmente estão atuando como professores. Com relação a utilização da $\mathrm{ABP}$, a maior parte dos participantes $(61 \%)$ respondeu que conhece, mas nunca utilizou, enquanto que $31 \%$ já usou e $8 \%$ desconhece.

Segundo Martins (2018), ainda existe resistência por parte de alguns professores na utilização de MAA e isso deve-se tanto por questões pessoais como profissionais de sua formação. Além disso, talvez os professores não utilizem a MAA por causa da resistência de seus próprios alunos.

Para os autores Martins et al. (2019), algumas dificuldades, como a resistência ao método, por parte dos alunos, podem ser comuns, pois a MAA precisa ser ativa ao invés de passiva. Desse modo, os alunos devem se adaptar ao método de forma a não criar um ambiente de frustração, mas sim um ambiente de aprendizagem, interação e conhecimento.

Quando questionados se a aplicação de metodologias ativas em sala de aula contribui/estimula o aprendizado do aluno, os participantes poderiam optar por uma das três categorias (muito, pouco ou não). Deste modo, 100\% dos sujeitos da pesquisa responderam muito, ou seja, os métodos ativos contribuem e estimulam o processo de aprendizagem do estudante. De acordo com Morán (2015), as MAA são o início para atingir as etapas mais avançadas da reflexão, integração cognitiva, generalização, reprodução de novas práticas, além de aprender através de desafios, atividades e informações contextualizadas.

Para Lovato et al. (2018), a utilização de MAA no ensino-aprendizado é uma forma alternativa de encontrar o interesse e a motivação dos alunos. Deste modo, tais metodologias necessitam estar em equilíbrio com os objetivos do professor, por isso, faz-se necessário estabelecer práticas que capacitem os estu- 
dantes a demonstrar diferentes interações sociais e tecnológicas.

Com referência ao seguinte questionamento: "Você já utilizou imagens durante o desenvolvimento de metodologias ativas em sala de aula?", 69\% declararam que sim e $31 \%$ não. Neste âmbito, as pesquisas sobre o uso de conteúdo imagético no ensino ainda são escassas, pois muitas vezes as imagens são consideradas apenas ilustrativas.

Em um estudo publicado recentemente, foi examinado se o uso de imagens é eficaz como uma ferramenta metodológica efetiva ou auxiliadora no desenvolvimento da argumentação científica no Ensino de Bioquímica. Para tanto, foi realizada uma análise comparativa entre as diferentes estratégias de ensino, com foco em estudos com e sem a presença de imagens. Concluiu-se que a utilização de imagens é relevante como ferramenta metodológica no ensino, de forma efetiva ou auxiliar no desenvolvimento da argumentação científica na disciplina de Bioquímica (SILVA, JORAS e SCHETINGER, 2021).

A próxima questão ("O que você espera desta oficina?") foi realizada de modo a ajudar as autoras a estruturar a oficina, para que assim, contemplasse as necessidades do público participante. Deste modo, as respostas dos participantes foram divididas em subcategorias (Tabela 1).

Tabela 1: Categorias das respostas dos participantes da oficina sobre a questão "O que você espera desta oficina?".

\begin{tabular}{c|cc} 
Subcategorias & $\begin{array}{c}\text { Respostas } \\
\left(\mathbf{n}^{\circ}\right)\end{array}$ & $\begin{array}{c}\text { Porcentagem } \\
(\mathbf{\%})\end{array}$ \\
\hline Aprender como utilizar a ABP & 05 & 38 \\
\hline Aprender a utilizar imagens em ABP & 03 & 23 \\
\hline Espaço de discussão e troca de conhecimentos & 02 & 15 \\
\hline Como construir um planejamento & 01 & 8 \\
\hline Aprimorar o conhecimento sobre ABP & 01 & 8 \\
\hline Aprender sobre sala de aula invertida & 01 & 100
\end{tabular}


A partir disso, tentou-se contemplar os itens solicitados, porém os detalhes da oficina encontram-se em um artigo científico escrito pelas autoras (BENDER et al., 2021). Dos itens solicitados, apenas o último (Aprender sobre sala de aula invertida) não foi contemplado por não fazer parte do objetivo da oficina, os demais foram contemplados.

Quando os participantes foram questionados sobre "Quais os benefícios você pode perceber com a metodologia proposta nesta oficina?", apresentaram três tipos de opiniões: i) mudanças que podem ocorrer nas atitudes dos estudantes; ii) mudanças que podem ocorrer nas atitudes dos educadores, e iii) forma de abordar conteúdos.

Quanto à mudança que pode ocorrer nos alunos, ao utilizar a ABP em sala de aula, 39\% (05) acreditam que:

Os benefícios são vários, mas posso destacar que esse tipo de metodologia propicia uma participação mais ativa dos alunos no seu processo de aprendizagem e permite romper paradigmas de um ensino centrado na transmissão de conhecimentos. P10

Além disso, percebeu-se que "construir algo em grupo nos faz aprender a escutar o outro e também refletir criticamente sobre o assunto de modo mais fluido. [...] P5". Para Cachinho (2012), através do trabalho em grupo, os alunos não só têm a oportunidade de investigar problemas da vida real e construir novos conhecimentos, mas também podem desenvolver um conjunto de habilidades gerais que podem ser utilizadas em várias situações sociais.

Neste contexto, ao utilizar problemas reais como ponto de partida, diálogo em grupo, além da responsabilidade individual e colaborativa e apoiados pelos professores, os estudantes podem realizar a autorreflexão de suas compreensões e ajustes para que ocorra a aprendizagem (LOVATO et al., 2018). Além disso, Cachinho (2012) também aponta alguns fatores importantes para os alunos aderirem a MAA em sala de aula. Dentre eles, inclui a motivação, o interesse pelos temas abordados e até a empatia do professor. Esses fatores também são efetivos na $A B P$, ressalta. 
Ao refletirem sobre as mudanças que podem ocorrer nas suas próprias ações como educadores, foi destacado que:

A metodologia da aprendizagem baseada em problemas permite primeiramente uma reflexão da própria prática pedagógica, de modo que o educador pense em situações de ensino e aprendizagem em que o educando seja o agente ativo do processo. [...] P6

O papel do professor vai muito além de guiar e orientar o progresso dos educandos. Cachinho (2012) ratifica que o papel do professor é determinante no processo, pois ele necessita despertar e orientar a curiosidade dos alunos, além de instigar e criar pontes entre as experiências de vida do aluno e o desafio colocado pelo problema no nível do pensamento reflexivo, o que levará a um nível mais alto de conhecimento. Deste modo, muitas vezes, ao longo do processo, os professores aprendem o que traz vantagem ao introduzir o assunto, direcionar, estimular e focar o aluno (LOVATO et al., 2018).

E por fim, os participantes listaram formas de abordar os conteúdos. Três deles elencaram que a utilização de imagens em ABP oportuniza explorar mais alguns conteúdos. Deste modo, a utilização de imagens em situações-problema em ABP é:

Uma proposta inovadora que poderá envolver a turma em busca das soluções para o problema e as orientações apresentadas aos estudantes. Além disso, proporciona trabalhar habilidades de análise, comparação e divulgação dos resultados encontrados. P8

Nova forma de abordar conteúdos relevantes em sala de aula e de fazer aflorar e desenvolver no aluno a habilidade da argumentação. Aumento do senso de responsabilidade dos estudantes [...]. Estimular a leitura, o emprego do raciocínio lógico e as discussões. P7

A leitura de imagens, em livros didáticos e outros tipos de gêneros discursivos utilizados por educadores e educandos, bem como em avaliações oficiais, tal como o Exame Nacional do Ensino Médio (ENEM), tornou-se uma habilidade valiosa no contexto sócio-histórico atual e, portanto, tem ocupado um lugar preponderante nas pesquisas em Ensino de Ciências (TOMIO et al., 2013). 
Em seguida, ao serem indagados sobre a percepção da aprendizagem com a oficina, a maioria afirmou ter aprendido muito (84,6\%). Além disso, quando questionados se pretendem trabalhar ABP com seus alunos, a maioria afirmou que $\operatorname{sim}(61,50 \%)$, outros $(23 \%)$ mencionaram que já usaram no passado, mas estão pensando em usá-la novamente, e os demais (15\%) já fazem uso dessa metodologia em sala de aula. Nenhum dos sujeitos respondeu às opções "Não" e "Talvez".

Da mesma forma, quando questionados se sentiram-se motivados(as) em utilizar as MAA em suas práticas docentes hoje ou futuramente, a maioria (92\%) respondeu "sim", 8\% "talvez" e nenhum respondeu "não". Pesquisas na área de ensino mostram a viabilidade em utilizar as MAA em diversas etapas da educação (DO NASCIMENTO et al., 2018; SOUZA e FREITAS, 2020; SILVA, JORAS e SCHETINGER, 2021). Para Cachinho (2012), o interesse da ABP na aprendizagem significativa é duplo.

Em primeiro lugar, o uso desta metodologia incentiva os alunos a desenvolver uma variedade de experiências de aprendizagem que vão além dos conteúdos substantivos e procedimentais das várias disciplinas. O autor ainda ressalta que essas habilidades também incluem uma gama de habilidades instrumentais, comunicação interpessoal e sistêmica, transição para o desenvolvimento pessoal e social e para a integração pessoal na sociedade e no mundo do trabalho.

Em segundo lugar, segue o autor, o aprendizado em ABP não é organizado hierarquicamente. Todo o aprendizado é considerado essencial para a resolução de problemas, além de terem o mesmo valor e, ao invés de serem mutuamente exclusivos, complementam-se (CACHINHO, 2012).

Quando indagados se através da utilização da imagem durante a oficina foi facilitada a construção de um problema em grupo, a maioria (77\%) concordou. Corroborando com o estudo de Rodrigues (2019), que utilizou a ABP para tratar sobre a temática astronomia como contexto no ensino da quantidade de movimento e os recursos didáticos usados incluem imagens. Neste caso, os estudantes receberam textos com imagens do PBL, tanto os alunos da rede particular 
(entre $63 \%$ e $68 \%$ ) como da rede pública (82,8\%) consideraram este recurso de fácil compreensão e convidativo. E, a minoria afirmou que as imagens não seriam necessárias, o texto em si era estimulante e curioso.

Sobre a finalidade e o quantitativo de imagens que cada participante utiliza em suas aulas, a maioria ( $77 \%)$ as utiliza na contextualização do tema que será trabalhado e a quantidade depende da aula. O restante dos participantes (23\%) mencionou que nunca utilizaram imagens, pois ainda não exerceram a profissão de professor.

Quanto aos critérios que os participantes costumam utilizar na escolha de imagens para aplicação em sala de aula, a maior parte (68\%) explicou que primeiramente verifica se a imagem corresponde a temática que será trabalhada e se auxiliará na compreensão do aluno quanto ao tema.

\begin{abstract}
Verificaria se a imagem corresponde a temática que será trabalhada e se dá suporte para abordar assuntos e conceitos de forma interdisciplinar e contextualizada. Para que assim possam fazer sentido ao estudante, sem estarem desconexas de sua realidade. P4

Quando procuro imagens para as aulas eu procuro para contextualizar, explicativo, exemplificar e agora depois da formação com vocês também pensei em usar para iniciar com uma abordagem problemática buscando avançar para um trabalho PBL. P13
\end{abstract}

Outro critério reportado pelos participantes da oficina (8\%) foi quanto a escolha da imagem para trabalhar em sala de aula foi referente a observação dos fenômenos físicos das imagens, tais como, escala de cores, resolução, etc. E por último, outro critério mencionado ( $8 \%$ ) foi sobre a procedência da imagem. Sobre ambos os critérios elencados, serão discutidos com maiores detalhes a seguir, dentro da próxima pergunta realizada aos participantes. Vale ressaltar, que dois participantes (16\%) não responderam essa questão.

Por fim, ao serem questionados sobre os procedimentos e cuidados que estabelecem ao utilizar imagens em suas aulas, a maioria (46\%) respondeu que observam o domínio público e os direitos autorais, 39\% dizem que observam os 
fenômenos físicos das imagens (escala de cores, resolução, etc.), os demais (15\%) não responderam à questão.

Esses achados corroboram com um estudo de Albuquerque et al. (2017). Os autores mencionam cinco cuidados principais elencados por estudantes de licenciatura em ciências biológicas participantes de um estudo em que realizaram sobre a utilização de imagens em sala de aula:

1. As imagens devem ser nítidas, pois imagens distorcidas podem levar a inúmeras interpretações; 2. As referências das imagens devem ser confiáveis e estar presentes na exibição; 3. As imagens devem conter legendas explicativas; 4. As imagens não devem ser muito complexas, pois devem sintetizar os conteúdos; 5 . As imagens devem ser representativas do conteúdo e a associação deve ser bem explicada (ALBUQUERQUE et al., 2017, p. 2364).

Deste modo, o uso de imagens em sala de aula é prerrogativa do professor, e embora tal uso seja fundamental no ensino de determinados conteúdos, "a ação do professor é que possibilitará a construção de conhecimentos" (ALBUQUERQUE et al., 2017, p. 2364). Os autores ainda complementam que no processo de ensino e aprendizagem de ciências, as imagens são consideradas essenciais à compreensão de estruturas e de fenômenos e estão cada vez mais presentes nas salas de aula do ensino superior. Porém, complementam, há pouco investimento em cursos de formação de professores no Brasil em disciplinas que tratam da educação visual para melhorar seu uso.

Ao final do questionário, os participantes opinaram sobre a contribuição da oficina na sua formação. Ao analisar essas respostas, 39\% pretendem continuar utilizando a ABP em sala de aula, adicionando a utilização de imagens.

Constatou-se ao final da oficina, que os pós-graduandos conseguiram refletir sobre suas práticas e visam mudanças. Sendo que 38\% pretendem estudar mais sobre o assunto e implementar esta metodologia em sala de aula e $23 \%$ pretendem começar a utilizar a metodologia proposta na oficina. Desta forma, acredita-se que a oficina serviu de incentivo aos participantes para que eles usem essa abordagem de ensino em sala de aula. 


\section{CONCLUSÃO}

Em razão da Pandemia, professores e alunos tiveram que se adaptar às mudanças que estão ocorrendo no mundo, incluindo na Educação. Portanto, a implementação de ações diferenciadas de ensino é necessária para proporcionar maior interação entre os alunos, aumentar o interesse dos mesmos pela aula, promover o pensamento crítico e colaborar com a argumentação na Educação Científica. Deste modo, esta oficina buscou ajudar estudantes e professores a utilizarem imagens para desenvolver situações-problema na ABP.

Mesmo sendo uma oficina de curta duração, pode-se enumerar, dentre os benefícios proporcionados pela metodologia utilizada, que a maioria dos pós-graduandos aprendeu muito $(84,6 \%)$ sobre a construção de situações-problemas em ABP utilizando imagens, além de se sentirem mais motivados em começar/ continuar a trabalhar com a ABP em sala de aula.

Quanto às concepções sobre a utilização de imagens na $A B P$, os resultados mostram que os acadêmicos de pós-graduação desta instituição reconhecem a importância do uso de imagens no ensino, além de estabelecer critérios de seleção e apontar os procedimentos e cuidados necessários no processo de utilização.

Relataram também, pelo menos, três benefícios que perceberam com a metodologia proposta na oficina, a saber, as mudanças que podem ocorrer nas atitudes dos estudantes; as que podem ocorrer nas atitudes dos educadores, e a inovação na forma de abordar os conteúdos. Além disso, por meio deste estudo, constatamos a escassez de produções científicas quanto ao uso de imagens vinculadas à $A B P$.

Deste modo, sugere-se que mais estudos sejam realizados de modo a promover a cultura visual na interpretação de imagens. Necessita-se criar essa cultura na formação inicial, assim como, nos mais diversos cursos formativos continuados. 


\section{REFERENCIAS}

ALBUQUERQUE, T. C. C. de.; COSTA, J. S.; CARNEIRO-LEÃO,A. M. dosA.; MARTINS, M. M. O uso de imagens em sala de aula: as concepções de professores e estudantes da licenciatura em ciências biológicas. 2017. p. 2361-2365. In: CONGRESO INTERNACIONAL SOBRE INVESTIGACIÓN EN DIDÁCTICA DE LAS CIENCIAS, 10, 2017, virtual. Anais eletrônicos...2017. p. 2361-2365. Disponível em: https://www.researchgate.net/publication/320475512_O_uso_ de_imagens_em_sala_de_aula_as_concepcoes_de_professores_e_estudantes_da_licenciatura_em_Ciencias_Biologicas. Acesso em: 28 set. 2021.

ARRUDA, J. S.; SIQUEIRA, L. M. R. de C. Metodologias Ativas, Ensino Híbrido e os Artefatos Digitais: sala de aula em tempos de pandemia. Práticas Educativas, Memórias e Oralidades, Fortaleza, v. 3, n. 1, p. e314292, 2021.

BARDIN, L. Análise de conteúdo. São Paulo: Edições 70, 2011. 229 p.

BENDER, D. D. B. B.; JORAS, L. E.; VENDRUSCULO, A. P.; SCHETINGER, M. R. C. Formação de professores em tempos de pandemia: elaboração de situações-problema no Ensino de Ciências da Natureza através de uma oficina virtual. Revista Vidya, Santa Maria, 2021. No prelo.

BONDIOLI, A. C. V.; VIANNA, S. C. G.; SALGADO, M. H. V. Metodologias ativas de Aprendizagem no Ensino de Ciências: práticas pedagógicas e autonomia discente. Revita Caleidoscópio, v. 10, n. 1, p. 23-26, 2019.

CACHINHO, H. Criando experiências de aprendizagem significativas: do potencial da Aprendizagem Baseada em Problemas. El Hombre y la Máquina, Cali, $\mathrm{n}$. 40, p. 58- 67, set./dez. 2012.

DOS SANTOS, C. E. R.; DE OLIVEIRA, L. P.; HERRERA, V. A. S.; DA SILVA, S.. Acessibilidade Digital em Ambientes Virtuais de Aprendizagem: uma Revisão Sistemática. EaD em Foco, Rio de Janeiro, v. 11, n. 1, e1143, ago./dez. 2021.

DO NASCIMENTO, E. R.; DOS ANJOS, F. L. M. R.; MENEZES, K. K. O.; DE OLIVEIRA, G. B. L. Narrativas digitais para uma aprendizagem significativa no Ensino Superior: qual a percepção dos estudantes? Educação Por Escrito, Rio Grande do Sul, v. 9, n. 2, p. 251-269, jul./dez. 2019.

GIL, A. C. Métodos e Técnicas de Pesquisa Social. 7. ed. São Paulo: Atlas, 2019, 26 p. 
LOVATO, F. L.; MICHELOTTI, A.; SILVA, C. B. da.; LORETTO, E. L. da S. Metodologias ativas de aprendizagem: uma breve revisão. Revista Acta Scientiae, Rio Grande do Sul, v. 20, n. 2, p. 154-171, mar./abr. 2018.

MARTINS, L. Jogos didáticos como metodologia ativa no ensino de ciências. 2018. 77 f. Trabalho de conclusão de curso (Curso de Licenciatura em Ciências da Natureza com habilitação em Física) - Instituto Federal de Santa Catarina (IFSC-SC), 2018.

MARTINS, E. R.; GOUVEIA, L. M. B.; AFONSECA, U. R.; GERALDES, W.B. Comparação entre o Modelo da Sala de Aula Invertida e o Modelo Tradicional no Ensino de Matemática na Perspectiva dos Aprendizes. Experiências em Ensino de Ciências, Rio Grande do Sul, v. 14, n.1, p. 522-530, maio. 2018./jan. 2019.

MORÁN, J. M. Mudando a educação com metodologias ativas. In: Souza, C. A.; Torres-Morales, O. E. (orgs.). Convergências midiáticas, educação e cidadania: aproximações jovens. Ponta Grossa, PR: UEPG, 2015. 19 p.

NIKOLAVEJA, M.; SCOTT, C. Livro Ilustrado: palavras e imagens. Tradução: Cid Knipel. São Paulo: Cosac Naif, 2011. 308 p.

PEREIRA, R. Método Ativo: Técnicas de Problematização da Realidade aplicada à Educação Básica e ao Ensino Superior. In: VI COLÓQUIO INTERNACIONAL "EDUCAÇÃO E CONTEMPORANEIDADE", 6, 2012, São Cristóvão/SE. Anais eletrônicos... São Cristóvão/SE, 2012, p. 1-15. Disponível em: https:// ri.ufs.br/bitstream/riufs/10116/47/46.pdf. Acesso em: 30 set. 2021.

PUCINELLI, R. H.; KASSAB, Y.; RAMOS, C. Metodologias Ativas no Ensino Superior: Uma análise Bibliométrica. Brazilian Journal of Development, Paraná, v. 7, n. 2, p. 12495-12509, jan./fev. 2021.

RODRIGUES, M. C. S. A ABP como estratégia didática e a astronomia como contexto no ensino da quantidade de movimento. 2019. 273 f. Dissertação de Mestrado (Programa de Pós-Graduação Profissional em Ensino de Física) - Universidade Federal do Sergipe, São Cristóvão-SE, 2019.

SAVERY, J. R. Overview of problem-based learning: definitions and distinctions. Interdisciplinary Journal of Problem-based Learning, Akron, v. 1, n. 1, p. 9-20, 2006. 
SILVA, F. B. N. da. O uso de metodologias ativas no ensino de ciências biológicas. 2020. 32 f. Trabalho de conclusão de curso em Ciências Biológicas (Instituto Federal Goiano - Campus Ceres), Ceres-GO, 2020.

SILVA, T. V. F. da.; JORAS, L. E.; SCHETINGER, M. R. C. Como o uso da imagem pode ser uma ferramenta metodológica para o desenvolvimento da argumentação científica no ensino de Bioquímica na graduação? Revista Humanidades \& Inovação, Tocantins, v. 8, n. 46, p. 398-414, jun. 2020/maio. 6.32021.

SOUZA, I. M. C. de.; FREITAS, M. C. M. A. A aprendizagem baseada em problemas (PBL) aliada ao ensino de ciências no $5^{\circ}$ do ensino fundamental $I$. 17 f. Trabalho de conclusão de curso - TCC2 (Universidade Evangélica de Goiás - Curso de pedagogia). Goiás, 2020.

TOMIO, D.; GRIMES, C.; RONCHI, D. L.; PIAZZA, F.; REINICKE, K.; PECINI, V. As imagens no ensino de ciências: o que dizem os estudantes sobre elas? Caderno pedagógico, Lajeado, v. 10, n. 1, p. 25-40, 2013. 


\section{O ATENDIMENTO} EDUCACIONAL

\section{ESPECIALIZADO EM} PARCERIA COM

\section{A CLASSE COMUM:}

UM ENRIQUECIMENTO CURRICULAR PARA TODOS

Thayane Azevedo Pereira de Souza 


\section{INTRODUÇÃO}

A Constituição Federal de 1988 define em seu artigo 205 a educação como um direito de todos e estabelece a "igualdade de condições de acesso e permanência na escola" (art. 206, inciso I) como um dos princípios do ensino. Tais direitos garantidos são reflexos de um importante movimento social em favor da inclusão de grupos minoritários que historicamente foram excluídos e segregados do processo de escolarização regular, entre eles, o público-alvo da Educação Especial (PAEE), que abrange os estudantes com deficiência, transtornos globais do desenvolvimento e/ou altas habilidades/superdotação, os quais eram atendidos em escolas e classes especiais.

A Declaração Mundial de Educação para Todos de 1990 e a Declaração de Salamanca de 1994, influenciaram a construção de políticas públicas voltadas para a Educação Inclusiva, a qual se constitui como um paradigma educacional alicerçado nos direitos humanos que articula a igualdade e a diferença como valores indissociáveis, defendendo a equidade de oportunidades de forma a superar as diferentes formas e mecanismos de exclusão presentes no contexto escolar.

A perspectiva da escola inclusiva adota como princípio a convivência e aprendizagem coletiva independente das diferenças e das condições inerentes à humanidade, enfatizando a importância e a potencialidade da heterogeneidade à serviço da construção de uma experiência formativa voltada para o pleno desenvolvimento e o exercício da cidadania. Nesse sentido, a escola inclusiva tem por desafio o atendimento à diversidade e a acomodação dos diferentes estilos e ritmos de aprendizagem dentro da sala de aula comum.

Com o objetivo de assegurar uma educação de qualidade para todos, a Política Nacional de Educação Especial na Perspectiva da Educação Inclusiva (BRASIL, 2008) estabelece a Educação Especial como uma modalidade de educação escolar transversal a todos os níveis e etapas da educação; orienta 
os sistemas de ensino para garantir o acesso, a permanência, a participação e a continuidade dos estudos nos níveis mais elevados do ensino e ressalta a importância do engajamento e parceria da família e da comunidade nesse processo. E com o propósito de atender às características e demandas dos estudantes PAEE, institui como dever do Estado a oferta obrigatória do Atendimento Educacional Especializado (AEE).

O AEE é definido como um serviço da Educação Especial que identifica, elabora e organiza recursos pedagógicos e de acessibilidade, oferecendo um currículo centrado no desenvolvimento da linguagem, da escrita e do raciocínio lógico e sua relação numérica, no ensino de Libras, Braille e uso de tecnologias assistivas, com o propósito de eliminar as barreiras que impedem a plena participação desses alunos no contexto escolar. A Resolução CNE/CEB $\mathrm{n}^{\circ} 4$ de 2009 institui as diretrizes operacionais para o atendimento educacional especializado na educação básica, em seu artigo $5^{\circ}$ preconiza que o AEE deve ser "realizado, prioritariamente, na sala de recursos multifuncionais (SRM) da própria escola ou em outra escola de ensino regular, no turno inverso da escolarização, não sendo substitutivo às classes comuns" (BRASIL, 2009).

No entanto, tal política, embora importante e significativa no que tange ao processo histórico de inclusão e de garantia de direitos deste público, adota uma perspectiva que corrobora com o caráter clínico de déficit e de insuficiência do estudante quando prioriza o processo de inclusão na via única do AEE centrado em atendimento na SRM (MENDES, 2018). Na prática, este modelo pode se desarticular dos princípios dos quais a Política Nacional de Educação Especial na Perspectiva da Educação Inclusiva (BRASIL, 2008) foi pensada, uma vez que o trabalho segregado do currículo comum reforça o estereótipo de que o problema está no aluno e não nas formas de organização das instituições escolares. A concepção de inclusão centrada na SRM, então, se configura como uma solução simplista e ingênua de que um atendimento semanal de curto período e a presença do professor especialista em Educação Especial neste espaço seja o suficiente para garantir uma educação de qualidade. 
Uma das funções do professor especialista, descrita na Resolução CNE/ CEB $n^{\circ} 4$ de 2009, é estabelecer articulação com os professores da sala comum visando a disponibilização de recursos e desenvolvimento de atividades para participação e aprendizagem dos estudantes nas atividades escolares e se esta atribuição for tratada de forma primária, se faz possível estabelecer uma parceria do professor de Educação Especial com o professor da sala comum para planejar e organizar estratégias e propostas pedagógicas para o grupo referência, garantindo que os estudantes PAEE estejam contemplados em suas especificidades e potencialidades, promovendo deste modo benefícios para toda a turma, uma vez que as expertises desses profissionais estariam articuladas, o professor comum com o domínio do conteúdo formal e das disciplinas e do professor de Educação Especial com o domínio sobre as diversas formas de ensinar e de aprender e dos recursos pedagógicos que podem auxiliar no processo de aprendizagem de todo o grupo.

Noquetangeàeducaçãodeestudantes diagnosticadoscomaltashabilidades/ superdotação, segundo Renzulli (2014), estes costumam exigir uma variedade de oportunidades e serviços educacionais, uma vez que o comportamento superdotado consiste na interseção de três características marcantes, sendo elas: capacidade acima da média, elevados níveis de comprometimento com a tarefa e elevados níveis de criatividade que, quando não contempladas, podem provocar tédio e falta de engajamento nas atividades.

Está previsto na Lei de Diretrizes e Bases da Educação (BRASIL, 1996), em seu artigo 59, que os sistemas de ensino devem assegurar aos educandos com necessidades especiais: "I - currículos, métodos, técnicas, recursos educativos e organização específicos, para atender às suas necessidades". Diante disto, o AEE deve disponibilizar programas de enriquecimento curricular de caráter suplementar para os estudantes com altas habilidades/superdotação, desenvolvidos no âmbito da escola pública regular, articulados com a proposta político-pedagógica da escola, a fim de desenvolver propostas que atendam às necessidades, habilidades e interesses desses alunos. 
O Ministério da Educação do Brasil elaborou, em 2002, o documento orientador intitulado "Adaptações Curriculares em Ação: desenvolvendo competências para o atendimento às necessidades educacionais de alunos com altas habilidades/superdotação" (BRASIL, 2002), apresentando diferentes alternativas de atendimento a estes estudantes: na classe regular comum, nas salas de recursos e por meio do ensino com professor itinerante. Na classe regular comum, o atendimento requer atividades de apoio paralelo ou combinado, podendo o professor da turma receber orientação pedagógica de docentes especializados no que se refere à adoção de recursos e estratégias didáticas que podem auxiliar na elaboração e no desenvolvimento das atividades de enriquecimento curricular.

O enriquecimento curricular se trata de proposta pedagógica que promove experiências educacionais diversas das que o currículo formal proporciona por estar estritamente relacionada com os interesses, as curiosidades e habilidades dos estudantes, e esta proposta pode ser desenvolvida de diferentes formas. Alencar e Fleith (2001) explicam que:

Para alguns ele implica completar em menor tempo o conteúdo proposto, permitindo, assim, a inclusão de novas unidades de estudo. Para outros ele implica uma investigação mais ampla a respeito dos tópicos que estão sendo ensinados, utilizando o aluno um maior número de fontes de informação para dominar e conhecer uma determinada matéria. Para outros, o enriquecimento consiste em solicitar ao aluno o desenvolvimento de projetos originais em determinadas áreas de conhecimento. Ele pode ser levado a efeito tanto na própria sala de aula como através de atividades extracurriculares (p. 133).

Diante do exposto nas legislações e das diferentes possibilidades que as mesmas oportunizam, este trabalho pretende discutir as estratégias empenhadas pelo setor de Atendimento Educacional Especializado para o desenvolvimento das propostas pedagógicas de enriquecimento curricular, desenvolvidas com os estudantes diagnosticados com altas habilidades/superdotação do ensino fundamental I do Colégio Universitário Geraldo Reis (Coluni-UFF), vinculado à Universidade Federal Fluminense. Desde 2014, o Coluni-UFF vem construindo os pilares de uma identidade institucional, sobretudo, acerca das concepções 
teóricas que organizam o trabalho do AEE, que iniciou na instituição no ano de 2020. A partir de então, as discussões foram se desdobrando entre a equipe docente e, nesse sentido, questionamos: Quais estratégias pedagógicas foram lançadas para operacionalizar o enriquecimento curricular para os estudantes com altas habilidades/superdotação?

É impossível desconsiderar que tais discussões e estratégias se desenvolveram em contexto pandêmico provocado pela Covid-19 que, por medidas sanitárias e de preservação da vida, fez com que as escolas em todo território nacional fechassem seus espaços físicos. A fim de atender a sua comunidade, o Coluni-UFF adotou o Ensino Remoto Emergencial (ERE), que se trata de práticas pedagógicas mediadas por plataformas digitais e/ou aplicativos, prevendo atividades síncronas e assíncronas. Diante dessa conjuntura, quais os desafios e as possibilidades no desenvolvimento dessas estratégias que surgiram nesse contexto remoto? Tal discussão foi realizada a partir de uma análise documental (LUDKE E ANDRÉ, 1986), com os objetivos de relatar e discutir os processos que compuseram as propostas de enriquecimento curricular.

\section{MÉTODO}

Esta pesquisa se configura de cunho qualitativo por buscar compreender um fenômeno em seu ambiente natural, onde o pesquisador é o principal instrumento de coleta de informações, interessando-se mais pelo processo do que pelo próprio produto (BOGDAN \& BIKLEN, 1994). Neste percurso da pesquisa, o pesquisador pode adotar diferentes meios de construção e análise das informações, um deles é a pesquisa documental, a qual os dados obtidos são originários somente de documentos. Ludke e André (2012) consideram como documentos quaisquer materiais escritos que possam ser usados como fonte de informação, entre eles, os arquivos escolares, que foram adotados neste estudo.

A análise de documentos foi realizada por meio do método da Análise de Conteúdo (AC) que, segundo Bardin (1979), consiste em 
um conjunto de técnicas de análise das comunicações, visando obter, por procedimentos sistemáticos e objetivos de descrição do conteúdo das mensagens, indicadores (quantitativos ou não) que permitam a inferência de conhecimentos relativos às condições de produção/recepção (variáveis inferidas) destas mensagens (p. 31).

O primeiro passo para a AC consiste na seleção dos materiais. Nesta pesquisa foram compreendidos os documentos institucionais de duas turmas que tinham estudantes diagnosticados com altas habilidades/superdotação, como os planos trimestrais da área multidisciplinar, os relatórios diários dos encontros síncronos, as atas de reuniões pedagógicas entre a equipe docente e o setor de AEE e das reuniões com as famílias dos dois estudantes, situados entre o ano letivo de 2020 e o primeiro trimestre de 2021.

A partir da seleção, foi realizado um estudo aprofundado dos documentos, orientado pela hipótese de que a proposta de enriquecimento curricular desenvolvida no âmbito de sala de aula do grupo de referência por meio da parceria entre o professor do AEE com o da classe regular promove um enriquecimento curricular para todos os estudantes na medida em que os interesses e potencialidades do aluno com altas habilidades/superdotação são contempladas nas propostas do currículo comum. Acreditamos que essa iniciativa além de permitir o aprofundamento em assuntos nos quais se manifestam as suas preferências e o desenvolvimento de suas habilidades intelectuais, sociais e emocionais no âmbito heterogêneo promove, também, a construção coletiva do conhecimento e um processo formativo significativo e de qualidade tanto para estes estudantes, como para os demais.

Esta etapa permitiu o avanço da pesquisa a partir da elaboração de categorias que orientarão a interpretação dos dados obtidos. Foram organizadas conforme o quadro abaixo: 
Quadro 01: Categorias temáticas da análise dos dados

\begin{tabular}{|c|c|}
\hline Categoria temática & \multicolumn{1}{c|}{ Descrição } \\
\hline Estudo de caso & $\begin{array}{r}\text { Levantamento das características, habilidades e } \\
\text { interesses dos estudantes diagnosticados com altas } \\
\text { habilidades/superdotação. }\end{array}$ \\
\hline Planejamento & $\begin{array}{r}\text { Momentos de reuniões com a professora de Educação } \\
\text { Especial para definição das propostas de enriquecimento } \\
\text { curricular alinhadas ao currículo comum para elaboração } \\
\text { das atividades. }\end{array}$ \\
\hline Desenvolvimento & $\begin{array}{r}\text { Andamento das atividades junto à classe comum e } \\
\text { envolvimento do estudante com altas } \\
\text { habilidades/superdotação com a proposta elaborada. }\end{array}$ \\
\hline Devolutiva & Repercussão das atividades na aprendizagem \\
dos demais estudantes.
\end{tabular}

\section{RESULTADOS E DISCUSSÃO}

Com a análise das categorias estabelecidas, percebemos que o setor de AEE do Coluni-UFF teve início na instituição em fevereiro de 2020 e logo foi atravessado pelo contexto pandêmico, o que gerou grandes desafios para consolidação do mesmo. O início deste trabalho foi pensado a partir da proposta pedagógica adotada pela escola para o Ensino Remoto Emergencial, na qual os docentes produziam e desenvolviam as atividades pedagógicas por meio do site do "Quarentuni", que se tratava de um ambiente virtual multimidiático, interdisciplinar e multimodal que permitia a utilização de diferentes linguagens para devolutiva das atividades propostas, além de ser um meio de promoção e manutenção de vínculo com a comunidade escolar.

No que tange ao programa de enriquecimento curricular para os estudantes diagnosticados com altas habilidades/superdotação, as atividades eram pensadas 
a partir das temáticas nas quais os alunos demonstravam maior curiosidade, como feminismo, ciências, super-heróis, gibis e etc... Estas foram sistematizadas sobre os pilares: pesquisa orientada, discussão e resolução de problemas, produção de material e estímulo à autoria. Estes pilares eram articulados na pretensão de desenvolver a superdotação produtivo-criativa, que segundo Renzulli (2014), "enfatiza o uso das informações (conteúdo) e habilidades de pensamento de uma forma integrada, indutiva e orientada para problemas reais" (p.543).

No primeiro trimestre letivo de 2020, o AEE produziu de forma independente e paralela as atividades a partir dos interesses que eram relatados nas reuniões mensais com os familiares dos estudantes com altas habilidades/superdotação, como as séries/desenhos que estavam assistindo, as leituras que estavam sendo realizadas, as atividades extraescolares que estavam frequentando, entre outros. Estas atividades eram enviadas mensalmente de forma separada por e-mail, pensadas única e exclusivamente para o desenvolvimento das habilidades dos mesmos.

Como exemplos, uma das atividades para um estudante com altas habilidades nas áreas existencial, que questiona o sentido da vida e da morte, e na linguística, que lida criativamente com palavras e símbolos, propunha a reescrita do último episódio da temporada do desenho animado "O incrível mundo de Gumball", pois o mesmo havia demonstrado uma certa frustração com o desfecho da trama, como foi relatado por seus responsáveis. O objetivo da atividade era se consolidar como o elo de interseção entre o interesse demonstrado pelo estudante e sua área de inteligência, proporcionando ao mesmo a oportunidade de desenvolver sua escrita criativa. E para a estudante com altas habilidades na área naturalista, que compreende a relação entre os seres vivos e o ambiente, foi proposto uma pesquisa sobre os pandas gigantes, considerando seu habitat, seus hábitos alimentares e reprodução para o desenvolvimento de um plano com ações ambientais e atitudinais que pudessem evitar a extinção dos mesmos, com possibilidade de utilização de recursos digitais como aplicativos e editores de texto e imagens para a sua produção, pois a aluna havia se mostrado profundamente 
abalada no encontro com a sua turma quando recebeu a notícia de que a espécie corria risco de extinção.

No entanto, percebemos que as atividades propostas, embora cuidadosas em relação à articulação com as preferências dos alunos, não obtiveram um engajamento exitoso. Poucas das atividades enviadas tiveram uma devolutiva satisfatória e, geralmente, eram as que envolviam algum tipo de produção artística voltada para apreciação da comunidade escolar por meio da plataforma "Quarentuni".

A partir desta percepção, o AEE desenvolveu diversas discussões com a equipe docente e empreendeu esforços em formações iniciais sobre as temáticas do campo da Educação Inclusiva a partir de palestras com convidados especialistas que versaram sobre os diagnósticos em diálogo com as características dos estudantes PAEE presentes na própria escola, a fim de construir um Plano Educacional Individualizado (PEI) de forma coletiva, visando a construção de uma cultura escolar pautada no princípio da colaboração.

Com a construção deste documento, foi possível organizar e sistematizar informações relevantes sobre a personalidade, os interesses, as preferências, as habilidades e as potencialidades dos estudantes com altas habilidades/ superdotação a partir da contribuição de todos os professores que atenderam os mesmos, possibilitando uma orientação inicial acerca do desenvolvimento do trabalho de enriquecimento curricular com estes alunos.

No segundo trimestre do ano letivo de 2020, o AEE desenvolveu um trabalho mais próximo aos professores da área multidisciplinar (que englobava as disciplinas português, matemática, ciências, história e geografia) da classe comum. As atividades de enriquecimento eram pensadas pelo setor de AEE e contavam com a colaboração dos regentes na construção e na devolutiva das mesmas dentro do planejamento dos encontros síncronos.

Neste período, por exemplo, uma das turmas dos estudantes estava desenvolvendo um estudo sobre o coronavírus, sua disseminação, mutações e 
ações necessárias para combatê-lo. A equipe do AEE propôs ao estudante com altas habilidades nas áreas existencial e linguística, que produzisse uma história que pudesse incentivar as demais crianças a conhecer e entender melhor sobre o coronavírus e a importância do distanciamento social e das outras medidas sanitárias. O referido estudante elaborou uma história dividida em episódios que englobava a temática com tema dos super-heróis, que se tratava do seu assunto de interesse. $\mathrm{Na}$ medida em que eram escritos, os episódios eram registrados no Quarentuni e compartilhados com toda a turma. O envolvimento dos demais estudantes foi tão interessante que culminou na produção de um e-book ilustrado intitulado "Homem Aranha versus coronavírus" e em uma manhã de autógrafos junto aos colegas das demais turmas da escola.

Movimento semelhante ocorreu com a outra estudante com altas habilidades, que estudava com sua turma sobre o oxigênio, a poluição e a sua interferência no ecossistema do nosso planeta. Visto que a áreas de inteligência eram naturalista e linguística, o AEE propôs uma experiência científica com materiais caseiros e acessíveis chamada de "vela mágica", que consistia no fenômeno de queima do oxigênio. A estudante foi incentivada a realizar o experimento com o auxílio de seus responsáveis, a escrever as suas hipóteses que geravam tal resultado para posteriormente pesquisar sobre o fenômeno e explicá-lo, relacionando-o com o aquecimento global. A proposta gerou uma produção em vídeo da estudante, a qual foi compartilhada com toda a comunidade escolar e proporcionou discussões e reflexões em sua própria turma.

Estas ainda se tratavam de atividades extras ao currículo comum, porém, foi percebido que os estudantes público-alvo se mostraram mais engajados em demonstrar esse retorno para o seu grupo de referência e o envolvimento da turma com as discussões em torno das devolutivas apresentadas mobilizaram outros desdobramentos para além daqueles que foram previamente programados pelos professores.

Essa perspectiva de atuação promoveu um protagonismo dos estudantes com altas habilidades/superdotação na medida em que se utilizavam de suas 
habilidades tecnológicas, sociais e intelectuais para apresentarem suas reflexões e/ou produções. Como produtos finais, também foram produzidos por eles vídeos de musical, outras experiências químicas, desafios matemáticos e de charadas, momentos de contação de piadas, e estas produções foram bem apreciadas pelos colegas das turmas nas quais estavam inseridos. No entanto, outros estudantes que não eram PAEE também promoveram riquíssimos debates e conversas, demonstrando interesse nas temáticas abordadas e desejo de um maior aprofundamento.

Diante deste cenário, em colaboração com a equipe docente da escola, oAEE reestruturou sua proposta de atuação, buscando estar cada vez mais articulado com aquilo que era desenvolvido na classe comum e esta ação foi possível em virtude da possibilidade de reuniões on-line devido ao contexto remoto. No primeiro trimestre de 2021, a carga horária dos encontros síncronos foi ampliada, proporcionando uma maior atuação da professora de Educação Especial junto aos demais professores. Esta se tornou a atividade primária do setor, a qual iniciou um planejamento colaborativo das propostas de enriquecimento curricular.

A partir deste momento, as propostas de enriquecimento não foram mais pensadas de forma paralela, mas sim articuladas com base nos conteúdos estabelecidos para o currículo comum. A parceria estabelecida possibilitou o planejamento das atividades de forma colaborativa. As atividades de enriquecimento foram divididas em atividades coletivas, realizadas por toda a turma, e individuais, as quais o estudante com altas habilidades/superdotação mobilizava as discussões no grupo de referência por meio de suas próprias pesquisas orientadas, descobertas e/ou produções. Desta forma, os interesses e as potencialidades desses estudantes PAEE foram contemplados na estrutura curricular adotada para o período.

Uma dessas atividades foi sobre a temática do carnaval, desenvolvida com o estudante que tem altas habilidades nas áreas naturalista e linguística. Os professores incentivaram a pesquisa de toda a turma sobre o significado desta festa para a cultura brasileira, no entanto, para a referida estudante instigou- 
se um aprofundamento nas questões sociais e econômicas que envolvem esta temática, inclusive o impacto da pandemia na vida dos trabalhadores do carnaval. A estudante produziu uma apresentação de slides no aplicativo "Canva" e apresentou em um encontro síncrono para toda a turma. Tal movimento proporcionou a reflexão coletiva sobre a geração de empregos e de renda e suas consequências para as classes sociais mais vulneráveis. Além disso, a turma compartilhou memórias afetivas a partir de suas experiências pessoais, o que proporcionou maior envolvimento, interação e fortalecimento de vínculo do estudante com o seu coletivo.

De acordo com a análise das devolutivas das atividades realizada a partir dos relatórios individuais, tal postura estratégica do setor do AEE promoveu para os estudantes com altas habilidades/superdotação um maior engajamento nas propostas ofertadas pela escola e maior autonomia em seu processo de aprendizagem em razão da oportunidade de manifestar o domínio sobre o uso das tecnologias e de suas diferentes aplicabilidades. De igual modo, demonstraram amadurecimento emocional e estreitamento de laços de vínculo e pertencimento com o coletivo da turma.

Além disso, os mesmos benefícios foram percebidos nos demais estudantes, uma vez que estes tiveram as mesmas oportunidades de acesso e de participação nas propostas de enriquecimento curricular. Tal ação assegurou uma educação de qualidade para todos por meio de um currículo flexível que articulou estratégias de ensino, arranjos organizacionais e recursos pedagógicos e tecnológicos, em prol da construção coletiva do conhecimento e da promoção de experiências educacionais significativas para toda a turma.

Noentanto, aindaidentificamosumalacunanoquetangeaoacompanhamento do setor de AEE e no desenvolvimento e avaliação das atividades propostas e isso ocorre em razão de haver somente uma professora de Educação Especial para atender a toda escola. Salientamos que a escola inclusiva requer uma mudança estrutural, organizacional e cultural, que implica em maiores investimentos não só em recursos físicos e estruturais, mas, principalmente, em recursos humanos 
para a composição do setor de AEE, de forma a garantir que os professores da classe comum estejam amparados e recebam orientação especializada como um suporte para atender tanto às necessidades dos estudantes com altas habilidades/superdotação, como as dos demais. Compreender a inclusão de forma abrangente e multidimensional (BOOTH e AINSCOW, 2011), implica em um compromisso político coletivo a partir do engajamento colaborativo entre a equipe docente da sala comum, o professor de educação especial, a gestão, a família e toda a comunidade escolar.

Importante pontuar que a presente pesquisa não teve por objetivo relatar detalhadamente o processo de produção e desenvolvimento das atividades de enriquecimento curricular desenvolvidas ao longo do contexto do Ensino Remoto Emergencial do Coluni-UFF, uma vez que compreende que a singularidade aponta as pistas para o desenvolvimento de um trabalho pedagógico que considera a diferença como matéria-prima para a construção coletiva do conhecimento. Portanto, a pesquisa foi desenvolvida na perspectiva investigativa dos princípios que nortearam a construção desta prática pedagógica inclusiva, complementando com os exemplos não exaustivos que pudessem revelá-los de forma a contribuir para a reflexão em outros contextos.

Por fim, cabe ressaltar que o trabalho desenvolvido no primeiro trimestre letivo de 2021 é o que mais se aproxima dos fundamentos e princípios da Educação Inclusiva, a qual defende que todos os sujeitos são iguais no direito à educação, assegurados de condições equitativas de acesso, participação e aprendizagem. Afinal, a escola inclusiva é comprometida com o processo ininterrupto e infindável de busca pela superação das barreiras que se apresentam no dinâmico cotidiano escolar, a qual adota mecanismos de equiparação das condições de acesso, de ensino e de aprendizagem nos diferentes espaços-tempos da escola para os diferentes sujeitos que nela estão inseridos, de forma a mobilizar políticas, práticas e culturas (SANTOS, 2008) em prol de uma educação pautada nos princípios de democracia, cidadania e equidade. 


\section{CONSIDERAÇÕES FINAIS}

A Educação Inclusiva lida constantemente com muitos desafios, uma vez que a sociedade, que tem um caráter elitista, homogeneizador e preconceituoso, encontra diferentes mecanismos para continuar excluindo e segregando. A escola inclusiva confronta essas práticas discriminatórias, compreendendo que as diferenças são inerentes à humanidade e isso implica em uma mudança estrutural, política, pedagógica e cultural para que todos os estudantes possam usufruir igualmente dos seus direitos enquanto cidadãos.

A educação de estudantes com altas habilidades/superdotação representa um desses desafios para a classe comum, pois esta deve acomodar os diferentes ritmos e estilos de aprendizagem. No entanto, a escola inclusiva deve assumir a heterogeneidade como matéria prima e a flexibilidade do currículo para atendimento da diversidade do contexto escolar e de promoção da aprendizagem coletiva.

Nesse sentido, com o percurso do Coluni-UFF compreendemos que o desenvolvimento do programa de enriquecimento curricular do AEE voltado para a parceria com o currículo da classe comum pode proporcionar benefícios para todos os estudantes, uma vez que promove a ampliação das oportunidades de aprendizagem para toda a turma, a partir do engajamento tanto das habilidades dos estudantes diagnosticados com altas habilidades/superdotação como dos demais, viabilizando experiências formativas significativas.

\section{REFERÊNCIAS}

Alencar, E. M. L. S. \& Fleith, D. S. Superdotação: determinantes, educação e ajustamento. São Paulo: EPU, 2001.

Bardin, L. Análise de conteúdo. Lisboa: Edições 70, 1979.

Brasil. Constituição da República Federativa do Brasil. Brasília, DF: Senado Federal, 1998. 
Brasil. Lei de Diretrizes e Bases da Educação Nacional. Lei n. 9.394. Brasília: Ministério da Educação, 1996.

Brasil. Parâmetros curriculares nacionais - adaptações curriculares. Brasília: Ministério da Educação/Secretaria de Educação Especial, 2002.

Brasil. Política Nacional de Educação Especial na Perspectiva da Educação Inclusiva. Decreto $n^{\circ} 6.949$ de 25 de agosto de 2009. Brasília: MEC/SEESP, 2008.

Brasil. Institui diretrizes operacionais do atendimento educacional especializado na educação Básica, modalidade Educação Especial. Resolução CNE/CEB $n^{\circ} 4$. Brasília, DF: Conselho Nacional de Educação/Câmara de Educação Básica, 2009.

Bogdan, R.; Biklen, S. Investigação qualitativa em educação: uma introdução à teoria e aos métodos. Lisboa: Porto Editora, 1994.

Booth, T. \& Ainscow, M. Index para Inclusão: desenvolvendo a aprendizagem e a participação na escola. Tradução: Mônica Pereira dos Santos, PHD. Produzido pelo Laboratório de Pesquisa, Estudos e Apoio à Participação e à Diversidade em Educação (LaPEADE), $3^{a}$ edição. RJ, 2011.

Lüdke, M. \& André, M. A pesquisa em educação: abordagens qualitativas. São Paulo: EPU, 1986.

Renzulli, J. S. Modelo de enriquecimento para toda a escola: Um plano abrangente para o desenvolvimento de talentos e superdotação. Revista Educação Especial, Santa Maria, v.27, n.50, p.539-562 set./dez, 2014.

Santos, M. P.; Paulino, M. M. Inclusão em educação: culturas, políticas e práticas. 2ed. São Paulo: Cortez, 2008. 


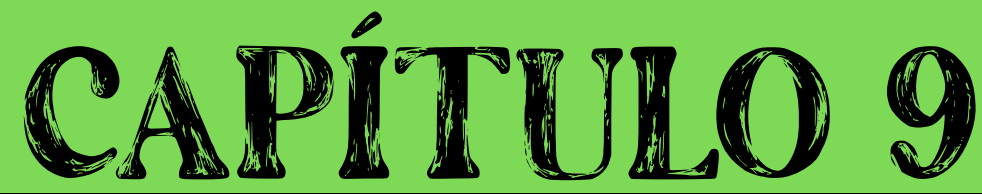

\section{PROJETO INVASÃO CULTURAL: NOVAS EMISSÕES E PERCEPÇÕES}

Laercio Fernandes dos Santos 


\section{INTRODUÇÃO}

Esta proposta objetiva apresentar um relato de uma prática pedagógica na área das Linguagens, a qual, há tempos, ocorria com sucesso, na modalidade de ensino presencial, porém, quando esta mesma prática foi ressignificada para o formato remoto, demonstrou a possibilidade da vivência significativa na e pela linguagem, numa experiência de vocalização do texto poético. A prática envolve turmas do Ensino Médio no projeto de vocalização intitulado Invasão Cultural, o qual busca contemplar a experiência singular do falante com a língua, mesmo durante o período pandêmico.

Na educação, consideramos a linguagem um elemento primordial, uma vez que é esta faculdade humana que permite a relação mediadora entre eu e tu, entre um homem e outro homem. Isso significa dizer que professor e aluno ocupam, alternadamente, os lugares enunciativos de eu e $t u$, garantindo o preenchimento de espaços na relação intersubjetiva. Sem esta relação, corre-se o risco de o profissional da educação "perder o rumo", dando espaço para o sentimento de tristeza. Com a pandemia, tivemos de buscar formas para garantir essa relação entre eu e outro. Assim, buscamos encontrar formas para assegurar essa relação humana, descobrindo as possibilidades na internet.

Fomos preparados para atuar na educação tendo como retorno o olhar do aluno, a expressão facial e o baixar ou levantar a cabeça sinalizando o aprendizado ou não. Isso tudo se perdeu, quando fomos forçosamente levados a nos afastarmos uns dos outros devido à pandemia. Logo, surgem as ferramentas digitais como possibilidade de resgate desta percepção, entre momentos de encontros de olhares, ou de câmera desligada, gestos e silêncios num mesmo espaço. Coisa que para nós foi difícil, porém fomos aprendendo e redescobrindo novas emissões e percepções. Nesse quadro atípico, uma ação pedagógica já cristalizada no seu fazer presencial se renova e assume o formato virtual. Trata-se da Invasão Cultural. 


\section{TEMPOS QUE ENSINAM A SE REINVENTAR}

Passamos momentos em que a sala de aula cedeu espaço para novos sons que precisaram ser percebidos, talvez, reinventamos a nossa escuta, uma vez que os sons foram ressignificados. Sons que nos moviam e direcionavam nossos olhos para sentir novas paisagens na profissão de educar.

Assim, pertinente observar uma atmosfera carregada de sensibilidade e emoção do reinventar o sentido da vida educacional, para que, de fato não se perdesse a chama de educar num momento que a escola se diluiu em outros espaços.

Reinvenção é a palavra e a atitude que todos nós, educadores, vivemos. O verbo reinventar é apropriado, para descrever a angústia da necessidade da mudança, pois esse verbo é bem forte para nós, enquanto sujeitos de um processo de renovação dolorido e, ainda mais, no momento pandêmico, que precisávamos descobrir a alegria de ensinar em tempos remotos. Alegria que sempre foi nossa companheira na missão de educar. Alegria de perceber o brilho no olhar do nosso aluno. Da Alegria de ver a nossa escola cheia. Alegria de ver o nosso aluno aprendendo. Alegria de ver os nossos alunos sorrindo no pátio e conversando alegres.

A nossa alegria, na verdade, sempre esteve o tempo todo em nossas vidas ao longo de nossa profissão, se não fosse por ela jamais estaríamos e resistiríamos a tantos impropérios que nos são apresentados. Porém, a alegria esmoreceu no início da pandemia, estávamos perdidos. Ela andou um pouco distante das nossas vidas, principalmente, porque não sabíamos o rumo do recomeço.

Neste processo de reinvenção começamos a mandar atividades "às escuras" para nossos alunos. Ficamos desolados porque não recebíamos o eco esperado, pairava o silêncio. Estamos falando de uma experiência de educador constituído há mais de 26 anos e cuja paixão sempre foi educar e conviver intensamente a atmosfera escolar enquanto espaço de humanização e sociabilidade. 
Não ouvir o som de retorno nos deixava muito desolados, inquietos, desesperados e tristes.

Os nossos olhos precisavam ser direcionados em outros horizontes, para que nós não fôssemos privados de ver a beleza, de ver o retorno. Nesse sentido, tivemos que buscar novos olhares, os olhos tiveram que ser educados para um novo recomeço, talvez, dolorido, como faz a águia velha, que mesmo sentindo muita dor, vai até uma montanha, bem alta, e no mais triste silêncio e solidão, bate com o bico numa pedra até que ele caia, para se renovar, parafraseando, o autor da famosa Lenda da Águia. Esta automutilação foi necessária, para que nascessem novas penas, novo bico e novas unhas.

Passamos batendo com o bico e, em muitos momentos, ele doía. Descobrimos a plataforma Classroom, que permitiu o reencontro; mesmo a distância, reinventamos o jeito de dar aula, "o bico precisava cair para nascer um novo bico". Essa renovação permitiu que se retomasse professor-aluno. Que a gente pudesse viver um pouco mais nossa essência de ensinar e ter a alegria também reinventada. A pandemia forçosamente exigiu a ressignificação na área educacional, usando a tecnologia. Diante de tal realidade, o educador precisou de rompimento paradigmático para não emperrar a possibilidade de continuar fazendo educação. "As ferramentas tecnológicas passaram a desempenhar um papel vital na reconstrução do "ambiente de ensino" e suprimiram uma necessidade imediata, garantindo que as aulas continuassem", (DIEDRICH e OLIVEIRA, 2021, p.211), com a afirmação das autoras percebemos que as tecnologias garantiram a intermediação humana nesse período crítico da história da humanidade.

Assim exigiu que buscássemos uma certa familiaridade com os recursos tecnológicos, num período forçadamente que nos apropriamos dela. Nesse âmbito, Silva, (2009), fala:

Diante desta realidade, não é difícil compreendermos que, ante o impacto das tecnologias de informação e de comunicação em todos os setores das atividades humanas, torna-se necessária até mesmo uma educação 
para a mídia no sentido de familiarizar os envolvidos na ação pedagógica com a área da tecnologia, (SILVA, 2009, p. 51).

Frente a colocação da autora, percebe-se que o educador deve aderir a tecnologia diante da transformação geopolíticossocial, para amenizar o impacto que a humanidade sofreu diante da imposição pandêmica.

Sendo assim, neste momento crítico vivenciado experimentamos a tecnologia que nos permite a construção do conhecimento e aproximação com nosso estudante, porém ela não é o fim para educar, mas sim o meio. A tecnologia pode muito bem servir como ferramenta para o ensino, porém ela sozinha é fria, é ineficaz, tanto do lado do professor quanto do estudante. Não podemos negar que os meios tecnológicos ajudam na interação do conteúdo com o ser humano, porém nega as relações inter-humanas. O mundo que a educação ajuda construir é o mundo de humanidade. Passamos por um mundo de aflições, de sofrimento por não termos contato físico com o outro ser humano. A tecnologia pode amenizar a distância, mas jamais trará o afeto, o olhar sensível que tem o ser humano. Por isso, inovamos nesse tempo de pandemia e, inclusive, conseguimos desenvolver projetos inovadores, mas pensar em educação à distância como a única forma de ensino é negar a inter-relação eu-aluno x tu-professor, ou vice e versa tu-aluno x eu-professor, ou seja, a relação eu-outo, uma relação instituída por (SANTOS, 2020). Isso porque as relações intersubjetivas estão sempre presentes. O linguista Benveniste diz: "bem antes de servir para comunicar, a linguagem serve para viver. Se nós colocamos à falta de linguagem não haveria nem possibilidade de sociedade", (BENVENISTE, 1989, p. 222). Isso porque uma das faculdades da educação é a linguagem e o que nos torna humanos. A linguagem é fator fundamental para o professor trabalhar com o outro.

O Francês Émile Benveiste (1989, p. 82) diz que para existir a efetivação da linguagem humana, necessita se estabelecer uma relação de eu e tu, caso contrário não há enunciação. Pois na linguagem os sons emitidos devem ser percebidos, ou seja, os sons emitidos eles têm de ser percebidos e para nós isso é essência da nossa profissão. Nós não sabemos fazer educação de outra forma. 
E nós passamos por alguns momentos tristes e a alegria deu espaço ao silêncio, pois enquanto educador gostamos de ouvir e perceber que o nosso som é percebido pelo outro.

Foi nesse redescobrir que projetos sempre desenvolvidos na presencialidade, foram trazidos para a modalidade remoto. Foi o caso do Projeto Invasão Cultural, que através da vocalização do texto poético "invade" salas de aula. Nesse sentido nos reinventamos e invadimos o virtual. Para Santos "o nome desse trabalho que leva a vocalização do texto poético escrito foram propositais porque entre a invasão e o cultural há uma ideia paradoxal. No primeiro momento em que as pessoas escutam o termo invasão, causa-lhes um certo estranhamento, (SANTOS, 2020, p. 47)". Percebemos que o termo invasão é transgressor propositalmente porque rompe barreiras da educação tradicional. Portanto, se trata de um trabalho que deixa marcas de para quem assiste e quem vocaliza na experiência significativa na e pela linguagem.

\section{A VOCALIZAÇÃO COMO EXPERIÊNCIA NA E PELA LINGUAGEM}

O Projeto Invasão Cultural tem como objetivo trazer aos estudantes da Educação Básica uma experiência significativa na e pela linguagem, através da vocalização do texto poético escrito. Assim, percorre algumas etapas para sua efetivação. Normalmente o professor leva os alunos para a biblioteca e disponibiliza muitos livros de poesia de diferentes autores e numa tentativa de permitir que os alunos se identifiquem com a obra literária. Porém, em tempos de pandemia exigiu uma mudança metodológica.

A metodologia utilizada para a Invasão Cultural Virtual se deu da seguinte forma: a) através das aulas do Classroom, o professor solicitou aos alunos de uma turma do Primeiro Ano do Ensino Médio, que escolhessem um texto poético e que esse deveria ser decorado, b)na aula subsequente os alunos receberam instruções de como postar a voz, c) numa outra aula foram feitos alguns treinos orais para que os alunos ficassem seguros, d) quando os alunos estavam prepa- 
rados para a atuação, foi solicitado o link das aulas de outras turmas da escola para que os alunos pudessem acessar, f) na última etapa, não menos importante, parte-se para a "invasão" das salas, neste tempo pandêmico, a sala era a janela virtual para o recomeço, numa experiência na e pela linguagem inovadora, que mesmo assim, deixou boquiabertos os "invadidos".

Neste Projeto, a gestualidade é levada em conta como constitutiva do dizer, ou seja, trata-se de componente que compõe a vocalização, uma vez que comparece na constituição dos arranjos vocais de forma e sentido na enunciação. Como o momento não permitia o modelo presencial, foi tentado, em frente a câmera, demonstrar os elementos que constituem a linguagem e são fundamentais para vocalização. A gestualidade se manifesta no vocal: o gestual da sobranceIha, a expressão facial, o movimento da boca, entre outros. Esse ato enunciativo inclui uma corporeidade, por isso, há um transbordamento no uso da língua.

Não se trata apenas de um exercício de dizer a poesia, mas é muito mais que uma declamação, é vivenciar com o outro a emoção e sentir a sensação que a arte da palavra provoca no ser humano. Como menciona Santos (2020, p. 39): "essa experiência humana de linguagem transforma os indivíduos em sujeitos de suas próprias histórias". Trata-se de vivenciar o belo através da experimentação de uma leitura transcendente, pedagógica e mais humana. Isso é o contato com o indizível que só acontece com a experiência profunda no mundo das artes e, nesse caso, a arte da palavra, que é linguagem, que é língua viva. Com o apoio teórico de Diedrich (2015) entendemos que essa arte (texto poético escrito) vocalizada é movida por arranjos individuais, na manifestação do aspecto vocal da língua. Para Juchem, "a vocalização do escrito ressignifica o discurso escrito, na medida em que retorna aos procedimentos de sintagmatização-semantização na transmutação de novos sentidos", (JUCHEM, 2017, p. 99). Isso traz uma nova dimensão linguística e permite novos caminhos para o ensino de língua materna.

O termo "invasão" se deve à imprevisibilidade da ação para a turma, que não sabe de antemão o que vai ocorrer, o que acaba gerando surpresa, susto, enfim, um misto de sensações. Isso também se deve ao poder da linguagem, 
pois é ela que estabelece a inter-relação com o outro. "A linguagem é para o homem um meio, na verdade, o único meio de atingir o outro homem, de transmitir e de receber mensagem" (BENVENISTE, 1989, p. 93). A ideia do projeto é exatamente essa de viver emoções, experiência na e com a linguagem, experimentando as sensações de transmitir e receber uma mensagem. Assim, no centro da questão, encontra-se a relação entre o eu e o tu: "vemos desta vez na língua sua função mediadora entre o homem e o homem, entre o homem e o mundo, entre o espírito e as coisas, transmitindo a informação, comunicando a experiência" (BENVENISTE, 1989, p. 229). Neste trabalho de vocalização, buscamos e intensificamos essa relação apontada por Benveniste. Com isso, a língua-discurso produz uma semântica própria, tornando-se, assim, uma significação intencionada, que segundo Benveniste (1989) é produzida pela palavra sintagmatizada. Invadir a sala física nós já sabíamos as consequências dessa vivência, por parte dos "invasores" e pelos "invadidos", mas não sabíamos que através do mecanismo virtual isso também tivesse um resultado surpreendente.

Através do evento enunciativo da vocalização do texto poético, permite estabelecer relações enunciativas as relações enunciativas: "a) falante-língua, b) falante-língua na manifestação poética e c) falante-outro", SANTOS (2020, p.47). Por mais que a experiência de vocalização do poético vivenciada no Projeto Invasão Cultural se volta de forma mais marcada para uma ou outra dessas três relações. Com isso, percebemos que experimentar e ressignificar mecanismos educacionais tornam-se um norte e uma constante dentro da educação.

\section{O ACONTECER DA LINGUAGEM}

Mesmo através da modalidade remoto foi possível perceber que os estudantes vivenciaram uma experiência significativa na e pela linguagem através de uma imersão enunciativa quando vocalizaram o texto poético. Com isso, ficaram nítidas as três categorias enunciativas: falante-língua, falante-língua na manifestação poética, falante-outro. 
a) relação falante-língua: Depois de acontecer o Projeto Invasão Cultural, através da invasão de salas virtuais, fica claro para nós que, os estudantes mudam sua relação com a língua e demonstram interesse de repetir isso em outras salas virtuais, ou seja, há uma nitidez aparente de satisfação em realizar este ato enunciativo. Isso rompe os limites da relação entre linguística, literatura e ensino, porque foram atingidos pela evocação da experiência de significação do projeto. Essa relação falante-língua é visível quando os alunos demostram uma pré-disposição para estarem na experiência linguística. Em muitas situações, motivados pela concepção de ensino de língua que marca o trabalho do professor e que o leva a apresentar uma metodologia diferente no trabalho relacionado com língua e literatura. Na vocalização do texto poético escrito, há a apropriação de novos sentidos para um discurso já existente. A ressignificação ocorre porque entendemos neste Projeto que cada apresentação se transforma em um discurso novo e único. Entendemos que através da vocalização o estudante se apropria do texto poético escrito, uma relação falante-língua carregada de significação, pois adentramos na seara do ensino de língua materna.

b) falante-língua na manifestação poética: realizar um trabalho através da internet é inevitável o distanciamento físico, porém percebeu-se o poético aconteceu, mesmo na distância. O poético não preexiste, ele se constitui no dizer, pois isso está na enunciação. Observamos a partir dos estudos enunciativos que manifestação poética se liga ao imaterial da língua, parte invisível, parte imensurável, mas que se configura nos arranjos vocais integralizadores. Por isso, a poética se constitui quando o estudante vive a experiência linguística. Assim, a manifestação poética suscita a irreversibilidade, assim, podemos dizer que o próprio falante na vocalização se torna "invasor" e "invadido".

c) falante-outro: A Invasão Virtual comprovou que na experiência de vocalização do poético, não importa o meio, institui-se o eu e o tu. Por isso, a enunciação é o homem se fazendo sujeito, na relação com o outro, pois para termos sons 
emitidos eles precisam se dirigir a outro que os escuta/percebe. Acreditamos que a singularidade da enunciação é manifestada quando o locutor, através do aspecto vocal, se apropria da língua, numa atmosfera linguística, seja ela virtual ou física.

Com essa experiência virtual deixamos registrada nossa certeza de que, no processo de vocalização em que o estudante se apropria do texto poético escrito, o professor e o aluno assumem espaço central no processo, e isso muda consideravelmente a relação que o estudante tem com a língua, com o poético e com o outro. Isso só é possível graças a uma concepção de língua e linguagem atrelada a uma metodologia que, considerando língua e poética como realidades constitutivas, conseguiu não só despertar interesse dos estudantes, mas propiciar uma experiência de significação que se marca no discurso do falante.

\section{CONCLUSÃO}

Percebemos que a tecnologia faz parte da sociedade pós-moderna e dias menos dias ela entraria no mundo educacional, porém ela foi introduzida de forma abrupta e nos redescobrimos através dela. Porém, o que fica é que educação se faz com gente para gente. As relações intersubjetivas do eu-aluno, tu-professor x tu-aluno, eu-professor jamais serão substituídas pela máquina. A educação é muito mais que conteúdos decorados. Ela transcende a humanidade que vive em cada um de nós. Isso é inegável.

Portanto, essa é nossa vida real, essa nossa angústia de aprender e perceber novos sons. Mesmo na distância, separados pela tela, sentimos o feedback. Assim, você precisa do que te alimenta e que é a percepção do teu som. Aprender ao ouvido a perceber outros ruídos, talvez daqueles que não tem acesso a uma internet de qualidade, que possibilita ouvir o eco do professor, o som da internet que cai. Daqueles que "perdem o fio da meada". Aprender a escutar novos sons. Dessa forma, nós vamos nos descobrindo enquanto educadores. Com dor no "bico", mas continuamos batendo, pois isso é necessário. Em tempos difíceis 
há sofrimento que nós não podemos evitar. Esse momento tem sido de sofrimento, por isso, nós precisamos acolher tudo isso, mas não hospedar dentro de nós. Isso faz parte da resiliência que é a capacidade que alguns seres humanos têm de se reinventar frente às dificuldades. O Projeto Invasão Cultural Virtual foi uma experiência marcante de ressignificação e só foi possível graças a uma concepção de língua e linguagem atrelada a uma metodologia que, considerando língua e poética como realidades constitutivas, conseguiu não só despertar interesse dos estudantes, mas propiciar uma experiência de significação que se marca no discurso do falante, mesmo em tempos que aprendemos a amenizar a falta da presencialidade através da internet.

\section{REFERENCIAS}

BENVENISTE, Émile. Problemas de linguística geral I. Campinas, SP: Pontes, 1991.

BENVENISTE, Émile. Problemas de linguística geral II. Campinas, SP: Pontes, 1989.

DIEDRICH, Marlete Sandra. Aquisição da linguagem: o aspecto vocal da enunciação na experiência da criança na linguagem. 2015. 148f. Tese (Doutorado em Estudos da Linguagem) - Programa de Pós-graduação em Letras, Universidade Federal do Rio Grande do Sul, Porto Alegre, 2015.

DIEDRICH, Marlete Sandra. A criança e sua relação com a interdição: a mobilização de arranjos discursivos particulares. Revista Desenredo, 2018, Passo Fundo, v. 14, n. 3.

DIEDRICH, Marlete Sandra. O poético que se instaura no vocal: a experiência da criança na linguagem. Revista Desenredo, 2020, Passo Fundo, v.16, n. 1, p. 114-126, jan./abr. 2020.

DIEDRICH, Marlete Sandra; OLIVEIRA, Marina. Sintaxe e pandemia: uma experiência de afeto na linguagem. Caderno de Letras, Pelotas, n. 40, p. $209-$ 219, maio/agos, 2021. 
JUCHEM, Aline. Por um saber sobre a escrita na interdependência entre atos enunciativos na universidade: a (re)escrita em voz alta. 2017. 207f. Tese (Doutorado em Estudos da linguagem) - Programa de Pós-graduação em Letras, Universidade Federal do Rio Grande do Sul, Porto Alegre, 2017.

SANTOS, Laercio Fernandes dos. Invasão Cultural: uma experiência de vocalização do texto poético. 2020. 79f. Dissertação (Mestrado em Estudos da Constituição e interpretação do texto e do discurso, sob orientação da Profa. Dra. Marlete Sandra Diedrich) - Programa de Pós-graduação em Letras, Universidade de Passo Fundo, Passo Fundo, 2020.

SILVA, Salvelina. Metodologia de Ensino da Literatura. Indaial: Grupo UNIASSELVI, 2009. 


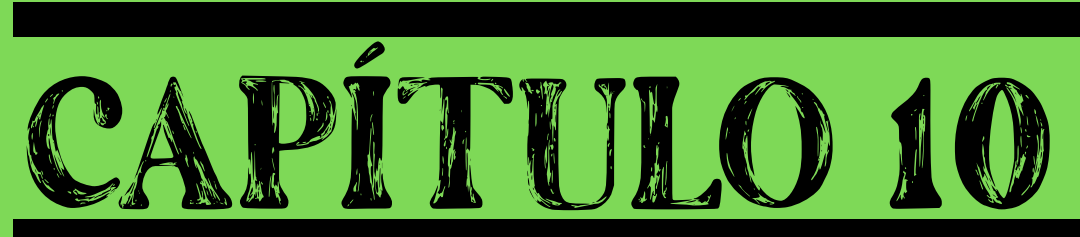

\section{ORALIDADE \& ENSINO: PONTES CONSTRUIDAS COM A CONTAÇÃO DE HISTÓRIA}

Jaqueline Estácio Barbosa de Jesus Santos 


\section{CONSIDERAÇÕES INICIAIS}

Este artigo, que tem como base teórica a Linguística Textual (LT), objetiva refletir sobre a relevância do texto oral no ensino de língua, a partir da prática da contação de história em dois vídeos, disponibilizados no canal do youtube no ano de 2021, em meses diferentes.

Os vídeos, com duração de no máximo 4 minutos, são apresentações de momentos de contação de histórias, por meio do uso da prática oral, uma das formas utilizada para o desenvolvimento da oralidade. Isso demonstra o papel relevante do ensino do texto oral na vida diária de uma criança, principalmente, no período atual de pandemia de Covid19, que já vem assolando diversos países do mundo, desde o final do ano de 2019.

Assim, está escrita parte da ideia de que a língua falada precisa ser ensinada no ambiente educacional como objeto de estudo. Pois, na história tradicional das pesquisas linguísticas sempre esteve à margem. Partindo, também, do princípio de que a língua possui duas modalidades, oral e escrita, a partir das noções de gêneros de Marcuschi (2001), onde uma não é superior a outra e precisam coexistir no sistema de ensino de língua materna.

Diante disso, pretende-se problematizar sobre o tratamento do texto oral no ensino, de forma efetiva, contemplando aspectos como as características, a funcionalidade e a aplicabilidade, em conjunto com a literatura, em especial, o gênero contação de história. Uma prática literária que pode "desenvolver uma quota de humanidade na medida em que nos torna mais compreensivo e abertos à natureza, à sociedade e ao semelhante" (CANDIDO, 1989, p. 117).

\section{A ORALIDADE NA HISTÓRIA DA LINGÚ́́STICA}

O tratamento do texto oral, no percurso dos estudos linguísticos, sempre teve objetivos diferenciados. "A rigor, a linguística não analisava nem a fala nem a escrita. Quando observava os textos orais, analisava uma fala idealizada, 
depurada de certas características que não se afiguravam, historicamente, como pertencentes a alguma norma" (MARCUSCHI, 2007, p. 24).

$\mathrm{Na}$ história dos estudos linguísticos, quando o texto oral recebia atenção era, de forma assistemática, com diferentes motivações. Têm-se como exemplo dos estudos linguísticos, o olhar para o sânscrito pelos hindus, como também, o estudo feito pelo linguísta francês George Mounin Panini, há mais de 2.500 anos, na Índia. Esses estudos tinham motivações religiosas, pois, observavam as questões voltadas para as análises morfossintáticas.

$\mathrm{Na}$ abordagem formal da linguagem do século $\mathrm{XX}$, observa-se que a prioridade do objeto de estudo voltava-se para a língua enquanto sistema abstrato, retirando as pesquisas de cunho pragmático e ideológico, e, por sua vez, os trabalhos ligados ao efetivo processo comunicativo.

Os primeiros trabalhos, realizados sobre a língua falada no Brasil, iniciam-se com a criação de projetos. Pesquisas em instituições de ensino, que visavam observar e catalogar dados concretos da fala com o instrumento tecnológico de gravação de áudio.

É nesse cenário que se iniciam as reflexões sobre o texto oral, ainda de forma acanhada. No final do século XX, percebe-se que o Ministério da Educação e Cultura, através dos Parâmetros Curriculares Nacionais (PCN), revisa os currículos que orientam os educadores, em especial do ensino de língua materna, determinando um olhar acurado para a linguagem oral.

\section{CONCEITO DE TEXTO ORAL}

O tratamento do texto oral nos estudos linguísticos, de forma sistemática, ainda, é recente. Sendo assim, a concepção de língua falada, adotada, neste trabalho, parte da proposta de Marcuschi e Dionísio (2005), com revisão atual de Heine (2012). Considere, a seguir, a concepção de língua falada: 
tuações comunicativas autênticos, formais ou informais em condições de proximidade física, ou por meios eletrônicos tais como rádio, televisão, telefone e semelhantes. (MARCUSCHI; DIONÍSIO, 2005, p. 71)

A partir dessa proposta de língua falada, Heine (2012) faz a revisão no aspecto do uso da expressão 'produção linguística', apresentada pelos autores, para 'produção linguístico-semiótica. De acordo com a autora, "essa sugestão objetiva evitar a dicotomia entre elementos paralinguísticos (elementos não verbais de comunicação, isto é, meneios de cabeça, gestos, variações prosódicas) e elementos linguísticos (código linguístico) [...]" (HEINE, 2012, p. 202), um enfoque tratado nos estudos formais. A exclusão desses elementos semióticos conduz a uma concepção de língua falada de cunho formal.

Ao tratar do texto oral, considerando tanto os elementos não verbais como os elementos linguísticos, evita-se a dicotomia entre eles, ampliando o tratamento visto anteriormente. Liame ao que foi dito, segue-se a citação de McCleary e Viotti (2017, p. 171):

A comunicação humana envolve corpos em ação, em um processo semiótico contínuo que se vale de todos os recursos corporais disponíveis: a voz, com todas as suas diferenças de qualidade e impostação; o rosto, com todas as expressões que sua musculatura permite; o direcionamento do olhar; a cabeça, o tronco, e mesmo os membros inferiores, com todas as posições que podem assumir; e os braços e as mãos, com todas as configurações passíveis de serem feitas.

A partir dessa constatação, torna-se relevante compreender que, em sua constituição, o texto falado, além do código verbal, possui estratégias semióticas, a saber: meneios da cabeça, entonação, riso, olhar, face, postura dos interlocutores, hesitações, interrupções etc. Além disso, observa-se que o texto oral pode acontecer na modalidade prototípica, como através de gêneros não prototípicos, a exemplo, conversas por rádio, conversas telefônicas, aulas, monólogos.

Enfim, é necessário ressaltar que o texto falado passa a ser focalizado, de modo mais sistemático, a partir da perspectiva sociointeracionista $(\mathrm{KOCH}, 2004)$. Nesse momento, a língua é vista "[...] como fenômeno interativo e dinâmico, vol- 
tado para as atividades dialógicas que marcam as características mais salientes da fala, tais como as estratégias de formulação em tempo real" (MARCUSCHI, 2010, p. 33).

\section{A PRÁTICA DA CONTAÇÃO DE HISTÓRIA NO AMBIENTE DE ESCOLAR}

A contação de história é uma prática oral, presente na humanidade há muito tempo. Ela é vista nas diversas culturas como: africana, indígena, européia e asiática. Essa é uma das formas milenar da humanidade perpetuar os seus conhecimentos, suas culturas, seus costumes, e, cronologicamente é anterior a escrita.

No entanto, ainda, têm-se mitos relativos à superioridade da escrita sobre a oralidade, vistos nos ambientes formais como a escola, ou seja, a escrita tem mais prestígio do que a fala. Essa foi uma das perspectivas dos estudos linguísticos que consideravam a dicotomia da linguagem, uma abordagem que apresentava pólos diferentes para a escrita e a fala.

Hoje, busca-se refutar essa perspectiva, principalmente, a partir da proposta do contínuo tipológico entre a fala e a escrita, de Antônio Marcuschi (2003). Uma abordagem que traz a relevância de se trabalhar com os gêneros orais em sala de aula, a exemplo com a contação de história, como forma de se construir possibilidades de conhecimentos sobre a língua falada. Para o referido autor, existem gêneros orais com traços mais formais ou menos formais, que podem ser objetos de estudo, trabalhados no contexto de ensino de língua.

Assim, alguns fatores podem ser identificados, quando se trata de ausências no tratamento da oralidade no ensino de língua, nos ambientes formais, tais como: a falta de preparo dos profissionais da educação e de profissionais do ensino de língua; a falta de planejamento para tratar dos aspectos característicos ao texto oral com os gêneros orais. Isso porque para Crescitelli e Reis (apud ELIAS, 2011, p. 31) "[...] o ensino da oralidade também deve ser efetuado por meio da 
análise da fala contextualizada, em interações face a face ou em falas individuais [...]", o que permite compreender que "[...] estudar o texto oral de maneira contextualizada, observando sua organização e complexidade, constitui uma forma de levar o aluno a ter consciência dos traços da oralidade." (IDEM, p. 34)

O trabalho com a contação de histórias, desenvolvido, a exemplo, com crianças pequenas, no ambiente escolar, leva em consideração que "na Educação Infantil, é importante promover experiências. Vivencias, nas quais, elas possam falar e ouvir, potencializando sua participação na cultura oral, pois, é na escuta de histórias, [...] que a criança se constitui ativamente como sujeito singular e pertencente a um grupo social." (BRASIL, 2018, p. 44).

A partir do uso da contação de história é possível também, ao longo do tempo, desenvolver a conscientização do sujeito, entendida na perspectiva de Freire (1979), como uma atitude crítica do homem perante a história. Neste sentido, o autor pontua que esta é uma ação constante: algo que deve perdurar. Por isso, a conscientização ser concebida como um compromisso histórico, revelando, portanto, a existência da relação entre conscientização e mundo. Na verdade, com conscientização o sujeito toma posse da sua realidade. Nesse caso, podese inferir que quanto mais o homem se apropria da realidade, mais consciente fica para criticar sobre a mesma.

O que se percebe, portanto, com a contação de história, no trabalho cotidiano na vida criança, é que permite diversas possibilidades de aprendizagem. Ao participar dessa prática, a exemplo, a criança é estimulada a criar, a imaginar, a pensar. Nesse sentido, Freire (1979) assevera que o homem é um ser capaz de pensar, de tomar decisões e de agir sobre um objeto ou realidade, mesmo que, inicialmente, seja de forma ingênua. Porém, com perspectivas de desenvolvimento crítico para a tomada de consciência, posteriormente.

Então, o trabalho com prática da contação de história na escola possibilita explorar elementos que fazem parte dos conhecimentos tanto acerca da língua falada (entonação, marcadores conversacionais; repetição; hesitação; gestos; 
expressões faciais com os olhos, sobrancelhas), como também de aprendizagens relativas a interação, a socialização, a afetividade.

\section{CONTAÇÃO DE HISTÓRIAS EM TEMPOS DE PANDEMIA}

Nos últimos dois anos, as pessoas tiveram que fazer mudanças em diversos setores de suas vidas, em virtude da pandemia da Covid19, que dizimou um número extenso de vidas em várias partes do planeta. Muitas foram às perdas. Houve diversas transformações na estrutura social da humanidade, ao longo desse período.

Atitudes e comportamentos para com o outro precisaram ser alterados. Vieram à tona as reais prioridades na existência das pessoas. Assim como, o modo de educar, de criar e de cuidar das crianças precisou ser repensado. A vida ganhou um novo sentido. Mas, surgiram novos questionamentos:

- como trabalhar os sentimentos, os medos, as incertezas, as dúvidas, as angústias, os sofrimentos e demais pontos pertencentes aos sujeitos, nesse caso as crianças, em período de isolamento social?

Esse questionamento foi muito intenso, principalmente, para as famílias e as escolas. Pensar em novos paradigmas que norteassem o caminhar de cada envolvido. De um lado, a escola no compromisso formal de ensinar aos seus discentes, preparando os profissionais para lidar com as novas roupagens. A família, por outro lado, com a responsabilidade de acompanhar na integra a educação familiar e formal, ao mesmo tempo, considerando os diversos fatores emergentes das situações, em decorrência da pandemia, como desemprego, fome, depressão...

Como tudo precisou de inovação, o período de pandemia evidenciou um grande aumento de adaptações e formas de expor os resultados dos processos ou as caminhadas dos sujeitos na educação. Para não ficarem ilhados, os sujeitos passaram a se conectar com mais frequência às redes sociais. As famílias e 
escolas passaram a adotar as novas tendências do momento e usaram youtube, instagran e facebook como meios para divulgar.

As transformações na educação, para algumas famílias, nesse período, tiveram bons resultados como se verá nos dois exemplos, apresentados nessa seção. Isso porque, houve o intenso trabalho de ensino da língua oral, a partir de práticas sociais como a contação de histórias e as mediações de leituras, dentro de uma rotina. Práticas exitosas, que levaram ao resultado de gravações em vídeos, disponibilizados pelo canal do youtube de Jaqueline Santos, cujo título é 'Junte-se a Uesley e Ualysson...'

Nesse canal, com mais de 80 inscritos, existem vários vídeos com as produções das crianças, dentro de categorias (capoeira, diferentes lugares, brinquedos e brincadeiras, músicas, memorização/oralização, declamações de poemas...), uma forma de poder expor o progresso de seus desenvolvimentos. Nele, também, possui uma escrita, informando para o usuário a descrição das atividades.

Os vídeos possuem a presença das crianças juntas ou separadas, de acordo com a temática utilizada, em locais da casa como sala e quarto, bem como em ambientes externos como praças, parques, praias. Elas se encontram sempre vestidas e expondo as suas comunicações, a partir dos recursos como a voz, as expressões faciais, os gestos, os movimentos com o corpo, acompanhadas e sob a supervisão da mãe, como se observa no áudio de algumas gravações.

As crianças, Uesley 5 e Ualysson 2, são autistas e no período da pandemia ficaram dentro de casa, sem contato, interação ou comunicação social. Nesse ambiente, elas têm a figura de uma mãe que é professora, conhecedora da importância de desenvolver práticas orais para o processo de desenvolvimento da criança. Uma mãe que faz um trabalho com dedicação exclusiva no cuidado para com os filhos, encontrando uma forma de introduzir na rotina das crianças o momento da contação da história, embora, o mais provável que tenha acontecido, inicialmente, é uma relutância ao novo, sanado com o decorrer dos dias e tempos. 
O prazer de se contar as histórias, normalmente, contagia as crianças, que passam a escutar e a acompanhar as entonações das vozes, as expressões faciais, as diferenças dos enredos, mostrando assim, as riquezas das possibilidades da imaginação e da criação das histórias. Isso porque, a prática de se contar permite: despertar a curiosidade; instigar a imaginação; aumentar a autonomia; vivenciar situações de medo e de angústias. A contação desenvolve o ensino da língua falada, considerando as características, a funcionalidade e a aplicabilidade.

No Exemplo 1, tem-se o vídeo, com aproximadamente 27 segundos, contando com a presença de Uesley, 5 anos, e Ualysson, 2 anos, postado no dia 12 de outubro de 2021, cujo título é 'Junte-se a Uesley e Ualysson: fantoches'. Nessa gravação, as crianças estão fora do ambiente de casa, em específico, na Biblioteca Comunitária Paulo Freire, no subúrbio ferroviário da cidade de Salvador. Nesse momento, elas aparecem sentadas, próximas a uma grande mesa, numa sala repleta de estantes de livros. Juntas, tentam contar histórias, cada uma, utilizando um fantoche diferente, atrás de uma moldura pequena para uso de fantoches que lembra o teatro. Ao lado de ambas, tem-se uma figura de um grande livro.

Os meninos fazem uma pequena encenação, oralmente, sobre a história do super livro. A cena é muito emocionante e vemos os diversos recursos, utilizados para entreter o espectador como a voz, os meneios da cabeça, o sorriso, os movimentos do corpo. Além disso, fazem com que o fantoche tenha vida, podendo interagir com o outro.

Ainda, nesse vídeo, Uesley inicia a sua fala: - Estou na biblioteca Paulo Freire, venham ver o super livro. Nesse momento, ele interage com o fantoche, fazendo movimentos na sua boca e ao mesmo tempo, conversando com o fantoche do irmão, chamando-o para ver o super livro. Isso demonstra que a "nossa oralidade nos conecta ao mundo e nos representa como um ser-ser-no-mundo, um ser peculiar, único, complexamente singular" (CARVALHO; FERRAREZI, 2018, p. 17). Essa interação é um passo muito importante no ensino da oralidade, pois, os sujeitos se constituem na relação com o outro. 
No que diz respeito à língua falada, em sua grande maioria, os sujeitos dizem o que já foi dito por alguém. Na verdade, para Bakhtin, os sujeitos se constituem na relação com o outro, a exemplo pela linguagem. Desde que chega ao mundo, ele recebe pela boca do outro as palavras. Bakhtin, em seus manuscritos de final de vida dos anos 1970 e 1971, diz que: "eu vivo em um mundo de palavras do outro. $E$ toda a minha vida é uma orientação nesse mundo: é reação às palavras do outro [...]".

Outra questão a pontuar, trata-se da fala, constantemente monitorada, pois, precisa-se adequar às práticas sociais. Não se usa as mesmas palavras, quando o sujeito conversa com a mãe em casa, ou quando está numa reunião de trabaIho, ou quando está no bar entre amigos.

Nesse sentido, a contação de histórias com fantoches é uma prática muito importante e desperta o imaginário da criança em todos os sentidos. Elas podem viajar e construir as histórias mais criativas e lindas. Esse trabalho, com crianças autistas, possui um significado muito positivo, pois, algumas delas precisam trabalhar o sensorial, as emoções, os sentimentos, a expressão e a oralidade.

Nesse mesmo vídeo, é possível observar Ualysson, ainda em processo da fala, tentando repetir as palavras que o irmão pronuncia. Também, observa-se que ele tem avançado na oralidade, pois sua voz tem sido mais perceptiva nos vídeos do segundo semestre de 2021. Outros aspectos são notados, nesse período, tais como: a participação em conjunto com o irmão; o uso constante da expressão do seu corpo; a frequência das participações nas gravações; o olhar, direcionado para a câmera; o uso das repetições.

No Exemplo 2, com duração de aproximadamente 3 minutos e 21 segundos, tem-se uma a contação de história, um reconto, com as crianças citadas. Esse vídeo foi postado no youtube no mês de agosto de 2021 e traz o título 'Junte-se a Uesley e Ualysson: Léo e Baleia'.

Uma gravação em família, homenagem aos dias dos pais, de acordo com descrição do vídeo. Nela, aparecem o pai e as crianças, sentadas numa cama 
de casal, no quarto, onde todos juntos estão direcionados para a câmera. Uesley está com o livro nas mãos e faz a contação, a partir de um gênero escrito, embora ainda, não saiba ler/decodificar.

Essa (re)contação é feita por ele para todos os presentes, de forma espontânea com algumas habilidades já adquiridas, a saber: folhear a página do livro na sequência da história; contar a história com inicio, meio e fim; utilizar as entonações nos momentos adequados, um aspecto muito importante que deve ser ensinado na língua oral.

Além disso, nota-se, a partir desse exemplo, que a prática de contar e recontar história tem a participação de todos os membros da família (pai, mãe, Uesley e Ualysson). Isso permite considerar que essa prática, no período com tantas fragilidades emocionais, foi uma tomada de decisão que aumentou as possibilidades de contato afetivo na família. Haja vista, a criação de momentos de prazer, ocorridos num espaço aconchegante, dentro de uma rotina que se espera um controle de situação, pelas crianças que necessitam de rotinas fixas.

Nesse exemplo, pode-se observar, ao final do vídeo, a presença de outro gênero oral, na fala de Uesley: agradecimento/declaração. Como é um momento de homenagear o pai, Uesley sob uma orientação, faz uma declaração sobre o seu amor. Um gesto muito simples, mas com um significado importante na vida das crianças em formação. Carvalho e Ferrarezi Jr (2018, p. 37), fazem uma indagação sobre isso, quando diz: "Você já pensou em agradecimento? Pois é... Trata-se de um gênero. $E$ pode ser um gênero oral. Ensinar as crianças a agradecer - não apenas a dizer obrigado - é algo muito necessário nos dias de hoje."

Por outras palavras, observa-se que o conhecimento profissional em educação, dessa mãe, auxiliou no desenvolvimento dos conhecimentos das crianças. Isso as ajudou no estimulo para criar suas próprias histórias, contando para uma câmera, e, posteriormente divulgando o trabalho. Nesse sentido, a prática de contar tem ampliado os saberes dos meninos, mostrando para eles que as suas histórias são tão importantes que podem ser contadas e perpetuadas a par- 
tir de um registro. E, que podem valorizar a criação literária, estimulando o sujeito a ser protagonista da sua própria história.

As criações literárias feitas por uma mãe, por meio das contações de histórias, possibilitaram que crianças, ao longo dos dias no período de pandemia, pudessem aprender e compreender a real situação, dentro dos seus limites de saber, imposta pelo isolamento social, sem ter acesso à escola física, aos parques, às praias, aos passeios e aos contatos com seus pares.

Nessa perspectiva, a contação para a família, exemplificada acima, teve impactos reais na constituição de sujeitos. Isso, porque a aprendizagem acontece com o sujeito, quando se tem de um lado aquele(a) que ensina/aprende e, do outro lado, aquele(a) que aprende/ensina. Existe uma relação entre os sujeitos de carne e de osso que possibilita essa aprendizagem. E, é através desse encontro que há constituição de sujeitos, por isso, a importância de se promover situações, práticas sociais, para que se efetivem, por exemplo, uma conversa prototípica.

Além disso, os sujeitos são um balaio de vozes, pois, vivem no mundo de palavras do outro, como afirma Bakhtin (1970 e 1971). E, as crianças aprendem no dia a dia, quando Ihes são ensinadas a forma de poder agir e de ser, nas diversas práticas sociais, a exemplo com a contação de histórias. Ressalta-se, ainda, que no processo de desenvolvimento da criança, nesse caso autista, existem desafios, limitações, controles, crises de choros, situações de descargas sensoriais que são importantes de serem observadas, pois, elas refletem na sua formação pessoal, social, emocional, cognitiva.

Por fim, há de se pontuar, nessa discussão, a questão da relevância da prática oral de contação de história para o ensino, seja ele na modalidade presencial ou de forma remota, como muitas instituições adotaram, ao longo do período de pandemia. Constata-se que houve a tentativa de trabalhos com a mediação de leituras e a contação de histórias, por parte das instituições escolares, numa perspectiva de aproximar o trabalho com a literatura, por considerá-la como direito de para todos. 
A literatura permite que o sujeito possa pensar e expressar as suas emoções de diversas formas, transmitindo, a exemplo, costumes e culturas. Para Candido (1989, p. 113), "a literatura confirma e nega, propõe e denuncia, apóia e combate, fornecendo a possibilidade de vivermos dialeticamente os problemas." Nesse sentido, entende-se a relevância da contação de história, considerando-a como um gênero oral literário. Assim, torna-se imprescindível a sua existência na rotina diária das crianças típicas ou atípicas.

\section{CONSIDERAÇÕES FINAIS}

Este artigo abordou a questão do tratamento da oralidade no ensino, a partir do gênero oral literário contação de história. Para tanto, considerou-se a sua relevância para abordar noções ligadas tanto à aprendizagem de língua oral, como também, as demais áreas que permitem que o sujeito possa ser crítico e pensante, sabendo também lidar com as emoções e com o outro.

Objetivava-se refletir o papel relevante de se trabalhar com o gênero acima, justamente, por conceber as diversas possibilidades de aprendizagens que podem ser alcançadas com o seu uso, a exemplo com crianças autistas. Por isso, Freire (1979) aponta que, quando o sujeito tem consciência da língua, apropriando-se dos seus usos na prática, então terá a consciência do impacto na sua vida, nesse caso, libertando-o.

Constatou-se, ao longo da discussão, os grandes benefícios que podem ser atribuídos ao uso continuo dessa prática oral, quando introduzida na rotina diária de crianças, mesmo em situações de isolamento social, como foi exemplificado.

Enfim, essa discussão ganha melhor embasamento ao considerar o uso do gênero oral contação de história, no dia a dia das crianças, compreendendo que a língua oral pode ser ensinada, tendo em vista as suas características, funcionalidade e aplicabilidade. Esse gênero pode ser olhado a partir das seguintes questões: entonações, repetições, hesitações, semiótica (olhar, dos gestos das mãos, movimentos com a cabeça, expressões faciais), emocionais e afetivas. 


\section{REFERENCIAS}

CANDIDO, Antonio. Direitos Humanos e literatura. In: A.C.R. Fester (Org.) Direitos humanos E... Cjp / Ed. Brasiliense, 1989.

CARVALHO, R. S de; FERRAREZI JR, C. Oralidade na educação básica: o que saber, como ensinar. São Paulo: Parábola, 2018.

BAKHTIN, M. Os gêneros textuais. In: . Estética da criação verbal. São Paulo: Martins Fontes, 2003.

BAKHTIN, M. Fragmentos dos anos 1970-1971. In: BAKHTIN, M. Notas sobre literatura, cultura e ciências humanas Org., trad., posfácio e notas Paulo Bezerra. Notas da edição russa Serguei Botcharov. São Paulo: Editora 34, p.21-56.

ELIAS, V. M. (org.) Ensino de Língua Portuguesa: oralidade, escrita, leitura. São Paulo: Contexto, 2011.

FREIRE, Paulo. Conscientização - teoria e prática da libertação: uma introdução ao pensamento de Paulo Freire. São Paulo: Cortez \& Moraes, 1979.

HEINE, L. M. B. Aspectos da língua falada. In.: Revista (CON) TEXTOS Linguísticos. Vitória - v.6, n.7. ano 2012 p. 196-216.

KOCK, I. G. V. A coesão textual. 19. ed. São Paulo: Contexto, 2004.

MCCLEARY, L; VIOTTI, E. Fundamentos para uma semiótica de corpos em ação. In FIORIN, J. L. (Org.) Novos caminhos da linguística. São Paulo, SP: Editora Contexto, 2017, p. 171-193.

MARCUSCHI, L. A. Da fala para a escrita: atividades de retextualização. São Paulo: Cortez, 2010.

MARCUSCHI, L. A.; DIONISIO, A. P. Princípios gerais para o tratamento das relações entre fala e escrita. In: MARCUSCHI. L. A. Fala e escrita. Belo Horizonte: Autêntica. [2005] 2007. p. 13-30. 
MARCUSCHI, L. A. Gêneros textuais: configuração, dinamicidade e circulação. In KARWOSKI, Acir Mário;; GAYDECZKA, Beatriz; BRITO, Karim Siebeneicher. Orgs. Gêneros textuais reflexões e ensino. 2 ed. Rio de Janeiro: Lucerna, 2006.

MARCUSCHI. L. A. Da fala para a escrita: atividades de retextualização. São Paulo: Cortez, 2001. [2010]

MARCUSCHI, L. A. A análise da conversação. 2. Ed. São Paulo: Ática, 1991.

CRESCITELLI, M. C; REIS, A. S. O ingresso do texto oral em sala de aula. In: ELIAS, V. M (ORG). Ensino de língua portuguesa: oralidade, escrita, leitura. S ] ao Paulo: Contexto, 2011.

Junte-se a Uesley e Ualysson: fantoches. Disponível em: $<$ https://www.youtube. com/watch?v=Zq4ta0TFLPc> Acessado em: 15 de out. de 2021.

Junte-se a Uesley e Ualysson: Léo e a baleia. Disponível em:< https://www.youtube.com/watch?v=mWt_-v_x958> Acessado em: 15 de out. de 2021. 


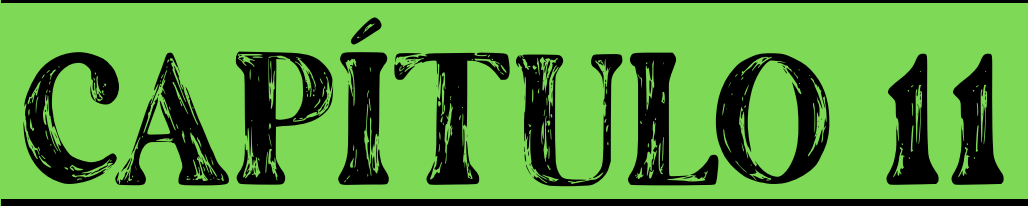

\section{ENSINO REMOTO E}

APRENDIZAGEM DIGITAL EM LÍNGUA PORTUGUESA: UMA PROPOSTA METODOLÓGICA

Walter Duarte Monteiro Neto Aline Kerber Bruniczak 


\section{INTRODUÇÃO}

A sociedade foi pega de surpresa com o advento do Covid-19 que gerou mudanças estruturais no modo de vida da população. A necessidade de se estabelecer, como forma de contenção da doença, o isolamento social, afetou vários setores, principalmente a educação.

Em 2020, foi realizado o estudo "A Educação não pode esperar" pelo Comitê Técnico da Educação do Instituto Rui Barbosa - CTE- IRB que o fechamento das escolas em março de 2020 impactou diretamente 47,9 milhões de alunos só na educação básica. Sendo assim, a suspensão das aulas indefinidamente acarretaria uma perda na aprendizagem dos estudantes.

Saraiva, Traversini e Lockmann (2020, p.3) afirmam, entretanto, que a paralisação das atividades presenciais na educação "não significou, necessariamente, um período de folga para professores e alunos." Em algumas instituições da rede pública, a suspensão das atividades presenciais realmente aconteceu, mas em muitas outras aconteceram atividades remotas.

Já na maioria das instituições da rede privada, depois do primeiro impacto, definiram que durante a crise sanitária haveria a transposição das atividades presenciais, por meio de ferramentas digitais, para um modelo de educação remota. A decisão de dar continuidade ao processo educativo recebeu suporte legal do Ministério da Educação (MEC).

Com a necessidade do uso do ensino remoto ${ }^{5}$, devido à pandemia gerada pelo Covid-19, os professores foram obrigados a se reinventar e aprender a utilizar as TICs. No entanto, na educação, usar recursos tecnológicos é um desafio diário, pois a grande maioria das escolas da rede pública, com poucas exceções,

$5 \quad$ Autorizado em caráter excepcional pelo Ministério da Educação e Cultura - MEC, por meio da portaria $n^{\circ} 343$ em 17 de março de 2020, a substituição das disciplinas presenciais pelo ensino remoto com o uso de meios e tecnologias de informação e comunicação para que as aulas fossem mantidas. Outras ações de enfrentamento para a pandemia foram criadas pelo Conselho Nacional de Educação (CNE) e podem ser estudadas no parecer CNE/CP $n^{\circ}$ 19/2020 que autorizou a continuação do ensino remoto até dezembro do presente ano, dando autonomia para as instituições de ensino de continuarem com as aulas online, em todos os níveis educacionais, tanto para instituições das redes públicas quanto das privadas. 
não possui infraestrutura e equipamentos que permitem o acesso dos alunos à tecnologia. Além disso, nem todos os professores possuem conhecimento teórico e prático para selecionar ou trabalhar com as tecnologias adequadas ao ensino.

Diante desse panorama, os Objetos de Aprendizagem (OA) merecem maior atenção, já que são desenvolvidos com propósito educacional e podem ser usados amplamente pelos professores, visto que a maioria dos Objetos de Aprendizagens (OAs) se encontram de acordo com as propostas presentes nos documentos normativos oficiais. Sobretudo no que diz respeito ao trabalho com a Língua Portuguesa e os objetivos que se pretende alcançar para os grupos ao qual esse estudo se destina.

No decorrer da realização desta pesquisa, verificamos que uma grande parte dos OADs podem ser encontrados na internet, e que grande parte desses objetos de aprendizagem digital foi financiada pelo Ministério da Educação (MEC) sendo elaborada e desenvolvida em universidades públicas e privadas, além de poderem ser encontrados em sites específicos e usados pelos professores livremente. Atualmente, o MEC disponibiliza três repositórios de Objetos de Aprendizagem: o Portal do Professor, a Rede Virtual Internacional de Educação (RIVED) e o Banco Internacional de Objetos Educacionais.

Durante a busca por objetos de aprendizagem em Língua Portuguesa, nos referidos repositórios, observamos uma carência para o conteúdo de pontuação, desta forma foi organizada esta proposta metodológica, visando auxiliar os professores em se tratando desse conteúdo, que para muitos alunos é difícil de ser assimilado e utilizado. Esta realidade se acentuou devido à troca de mensagens no meio digital, que possui uma linguagem própria, a qual permite contrações, o uso de emotions e, na grande maioria dos casos, nenhuma ou quase nenhuma pontuação.

Enquanto professores atuantes da Rede Pública de Ensino no Estado da Bahia e no Estado do Rio Grande do Sul observamos que não é fácil para todos os alunos a transição do $5^{\circ}$ para o $6^{\circ}$ ano. Muitas mudanças ocorrem neste processo, mas citaremos apenas três delas: o aluno deixa de ter apenas um pro- 
fessor e passa a ter vários; as disciplinas são separadas em tempos marcados de aulas de 50 minutos, o que demanda a necessidade de maior agilidade no desenvolvimento das atividades; e, o recreio é trocado para um intervalo de 15 minutos.

Especificamente na disciplina de Língua Portuguesa, além do processo de transição, os alunos apresentam dificuldades em transpor os conhecimentos construídos no $5^{\circ}$ ano, para a turma posterior, como exemplo, o uso dos sinais de pontuação. Diante deste panorama, a seguinte problemática foi levantada: as dificuldades de transpor os conhecimentos aprendidos no $5^{\circ}$ ano para a nova turma do $6^{\circ}$ ano podem ser minimizados a partir do uso dos objetos de aprendizagem digitais (OAD) para o Ensino de Língua Portuguesa?

O presente trabalho tem como objetivo geral apresentar uma sugestão de proposta metodológica utilizando objetos de aprendizagem digitais (OAD) para o Ensino de Língua Portuguesa, a ser implantada no Ensino Fundamental, nas turmas de $5^{\circ}$ e $6^{\circ}$ ano. E, como objetivos específicos: conceituar o que vem a ser objetos de aprendizagem digitais (OAD); pesquisar sites e repositórios gratuitos de objetos de aprendizagem digitais (OAD); e, alinhar a proposta a Base Nacional comum curricular (BNCC).

Para o alcance dos objetivos propostos, o seguinte percurso metodológico foi desenvolvido: análise da BNCC com enfoque nas competências gerais, competências específicas para a Língua Portuguesa, os eixos de integração correspondentes às práticas de linguagem, campos de atuação e códigos de objetivos de aprendizagem; pesquisa em sites e repositórios para analisar o que se encontra disponível para uso dos professores que não tenham conhecimento técnico para a criação de seus próprios OADs. A Construção da proposta metodológica foi criada em forma de sequência didática ${ }^{6}$.

6 De acordo com Antoni Zabala (1998, p. 18), sequência didática se trata de "um conjunto de atividades ordenadas, estruturadas e articuladas para a realização de certos objetivos educacionais, que têm um princípio e um fim conhecidos tanto pelos professores como pelos alunos." 
A proposta aqui apresentada foi pensada para utilizar o aplicativo WhatsApp como ambiente virtual de aprendizagem, portanto, pode ser utilizada em escolas que não possuem infraestrutura adequada para o uso dos OAD em sala de aula e que tenham alunos que só possuem celular como suporte para estudo. Outrossim, nos dedicamos a organizar uma proposta que valorizasse o conhecimento prévio do aluno e sua visão de mundo, fugindo da práxis que só usa os textos presentes no livro didático e exercícios padronizados/ repetitivos. Torna-se importante salientar que, não desvalorizamos o uso do livro didático como instrumento linguístico, até porque, em muitas escolas, os professores só contam com esse material como suporte para as aulas.

\section{REFERENCIAL TEÓRICO}

Como vimos, o novo panorama educacional, trazido com a pandemia do COVID-19, as aulas passaram a ser remotas, gerando desafios para todos os atores envolvidos, escola, família e sociedade. Os professores tiveram que desenvolver estratégias metodológicas para desenvolver suas práticas pedagógicas, através do uso das tecnologias educacionais que estavam a seu alcance.

Assim, infere-se que a sociedade tem passado por inúmeras mudanças em decorrência dos avanços tecnológicos, com ênfase nas Tecnologias da Informação e Comunicação (TIC), responsáveis por transformações em vários setores, inclusive nas instituições de ensino, que no contexto da pandemia, se intensificou. Segundo Lévy (1999), a tecnologia tem um enorme impacto na forma como aprendemos.

A prática pedagógica e a metodologia de cada docente encontram-se vinculadas à forma como a escola vem lidando com este novo panorama em que o aluno ainda não retornou para o ambiente físico da sala de aula. Outrossim, sabe-se que o contexto sociocultural em que os alunos estão inseridos também é um fator preponderante para que o professor desenvolva sua prática.

Conforme Behar (2020), o Ensino Remoto Emergencial (ERE) está vinculado à portaria $n^{\circ} 343$ em 17/03/2020, que impede que estudantes e professores 
frequentem as escolas com o objetivo de evitar a disseminação do vírus. Analisando o significado do verbete remoto, o autor esclarece que ele está relacionado a distância no espaço, ou seja, ao distanciamento geográfico. Além disso, o ERE foi emergencial e teve como consequência o engavetamento do planejamento pedagógico para o ano letivo de 2020.

O impacto foi muito grande porque a maioria dos currículos da educação básica, não foi criado para ser aplicado de forma remota. Portanto, repentinamente a gestão e o corpo docente escolar tiveram que pensar em como adequar a grade curricular a esse novo formato. Cabe ressaltar, que muitas escolas se encontram localizadas em contextos sociais, onde não é possível usar a internet.

O termo "ensino remoto emergencial" não pode ser considerado uma modalidade de ensino, como a Educação à Distância (EaD), mas uma alternativa de continuidade ao processo de ensino aprendizagem que até então ocorria na modalidade presencial. Oliveira et. al. (2020) esclarece mais sobre esse assunto quando afirmam que se trata de um modelo de educação que possui:

[...] aulas síncronas com uso de tecnologias digitais interativas via Internet e, por vezes, complementadas com materiais impressos, disponibilizados nas secretarias das escolas, com uma metodologia semelhante à do ensino presencial, incluindo horários fixos de aulas por períodos e com salas virtuais com o mesmo número de estudantes do modelo presencial. (OLIVEIRA, et. al., 2020, p. 3)

Portanto, o ERE não pode ser considerado sinônimo de Educação à Distância, pois segundo Moore e Kearsley (2008):

Educação a Distância é o aprendizado planejado que ocorre normalmente em um lugar diferente do local do ensino, exigindo técnicas especiais de criação do curso e de instrução, comunicação por meio de várias tecnologias e disposições organizacionais e administrativas especiais. Os principais aspectos a serem enfatizados a respeito dessa definição indicam que nosso estudo de educação a distância é um estudo de: •aprendizado e ensino; •aprendizado que é planejado, e não acidental; •aprendizado que normalmente está em um lugar diferente do local de ensino; -comunicação por meio de diversas tecnologias. (MOORE; KEARSLEY, 2008, p. 02). 
Corroborando com a fala desses autores Behar (2020, s/p), em sua conceituação sobre EaD, acrescenta que essa modalidade "abrange conteúdos, atividades e todo um design adequado às características das áreas dos conhecimentos gerais e específicos, contemplando o processo avaliativo discente.". Desta forma, reiteramos a necessidade de perceber as diferentes conceituações entre EaD e ERE para que não se confunda os objetivos de cada uma, bem como a metodologia.

Já em relação ao Ensino Híbrido, a conceituação apresentada está pautada em Christensen, Horn e Staker (2013), esses autores esclarecem que se trata de uma abordagem pedagógica que mescla tanto atividades presencias quanto atividades usando tecnologias digitais de informação e comunicação (TDICs) enfocando a aprendizagem no aluno, deixando de lado o ensino tradicional, onde o professor transmitia a informação.

Nesse contexto, a proposta metodológica que se apresenta é a do trabalho com Objetos de Aprendizagens (OAs), no ensino de Língua portuguesa, a partir da orientação proposta na Base Nacional Comum Curricular (BNCC), e, do uso das tecnologias educacionais, se configurando, portanto, em Objetos de Aprendizagens Digital (OAD), os quais vão colaborar de forma significativa na construção e desenvolvimento de uma aprendizagem contextualizada e com foco na realidade dos educandos.

Mas o que são os OAs? Segundo Tarouco et. al. (2003), pode-se considerar objetos de aprendizagem qualquer recurso suplementar reutilizável para apoiar o processo de aprendizagem, neste caso estão inclusos, cartazes, jogos, maquetes, etc. A definição que mais se adequa ao objeto de pesquisa deste estudo é a de Angulo et al (2006, p. 1) que em tradução livre seria: "o conceito de Objeto de Aprendizagem (OA) abarca principalmente um conjunto de materiais digitais que, como unidade ou agrupamento, permitem ou facilitam se alcançar um objetivo educacional"7. Sendo assim, se tratam de "recursos digitais que apoiam a educa-

$7 \quad$ "El concepto de Learning Object (LO) abarca principalmente a un conjunto de materiales digitales los que como unidad o agrupación permiten o facilitan alcanzar un objetivo educacional." 
ção e que podem ser reutilizados constantemente"8. São exemplos de objetos de aprendizagem: animação, slides, documentos de textos, vídeos, músicas, planiIhas, jogos, imagens, sites e objetos on-line, etc.

\title{
PROCEDIMENTO METODOLÓGICO
}

Esta proposta metodológica foi desenvolvida em formato de sequência didática. "As sequências didáticas ou como também podem ser chamadas sequências de atividades de ensino/aprendizagem são compreendidas como uma forma de encadear diferentes atividades ao longo de uma unidade didática". (ZABALA, 1998, p. 20).

As atividades desenvolvidas foram idealizadas e organizadas pautadas nos estudos de Ovide Decroly, médico belga conhecido pelos seus estudos na área de psicologia infantil, e considera a vida mental do indivíduo como unidade, portanto, os conteúdos não podem ser fragmentados no momento de serem estudados. Essa metodologia idealizada por Decroly é chamada de Centros de Interesse e tem como um dos seus principais pressupostos a globalização. "Centros de interesse são agrupamentos de conteúdos e atividades educativas realizadas em torno de temas centrais de grande significação para a criança." (CINEL, 2004, p. 33).

Há muitas características encontradas nessa metodologia, mas as que meIhor se alinham a proposta apresentada são:

\begin{abstract}
Satisfazer os interesses do educando, oportunizando situações de meIhor integração ao seu meio; aprendizagem a partir de dados, fatos e situações concretas e reais, extraídas da vida na escola, na família, na comunidade, no bairro; proporcionar situações para a construção de aprendizagens básicas; estimular a participação, a descoberta, a criatividade a iniciativa e desperta a curiosidade. (CINEL, 2004, p. 33)
\end{abstract}

Assim, a partir do exposto, foram escolhidos os seguintes OAD para fazer parte desta proposta: vídeos que se encontram disponíveis no Youtube e, portanto, de fácil acesso e possíveis de serem vistos na maioria dos celulares, sem

8 "recursos digitales que apoyan la educación y pueden reutilizarse constantemente." 
necessidade de alta memória ou configurações diferenciadas. Os vídeos são usados para criar um engajamento e interesse pelos conteúdos que serão inseridos gradativamente. De acordo com Gomes (2002, p. 43), não existem dúvidas sobre a importância do uso de vídeos didáticos em todos os níveis educacionais, [...] "especialmente se levarmos em conta que a televisão, presente em mais de $90 \%$ dos lares brasileiros, exerce grande influência no modo como lemos e conhecemos o mundo".

Slide com o conteúdo, disponível no site slideshare, de fácil acesso, sem necessidade de cadastro para visualização ou plugins especiais. Conforme Nascimento (2013, p. 11) "por meio da apresentação de slides há uma possibilidade de se aproximar o conhecimento científico com a vida do aluno". O uso dos slides proporciona: facilidade na construção de significados já que conceitos são concretizados por meio de representações visuais e/ou sonoras; melhor visualização de dados e/ou conceitos; síntese de ideias; quebra a monotonia; torna a aula mais participativa; sendo possível fazer uma ligação rápida entre os slides e outros programas, inclusive permite a inserção de links que redirecionam para a internet.

As atividades a serem desenvolvidas individuais e coletivamente serão repassadas aos alunos via WhatsApp. Para Vygotsky (1984; 2000), tanto o meio social quanto as relações sociais são significativas para o desenvolvimento humano e para a aprendizagem, pois segundo o autor é no contexto social que se internalizam os conhecimentos, as experiências e os processos cognitivos. Portanto, a perspectiva histórico-cultural de Vygotsky valoriza a aproximação entre os indivíduos e a troca de estímulos sociais.

A utilização do aplicativo WhatsApp, durante todo o ensino remoto, na maioria das escolas de Salvador/BA e Montenegro/RS, mostraram que, apesar do mesmo não ter sido construído para se tornar um ambiente virtual de aprendizagem, ele cumpriu o papel, pois se mostrou acessível para alunos e famílias, permitindo que as interações sociais fossem mantidas aproximando os professores da realidade familiar de seus alunos e possibilitando não só a mediação, mas 
o apoio nos processos de aprendizagem nos momento de incerteza gerados pela pandemia.

\section{ANÁLISE DOS RESULTADOS E DISCUSSÃO}

PROPOSTA METODOLÓGICA:

Professores: Walter Duarte Monteiro Neto/Aline Kerber Bruniczak

Disciplina/Área: Língua Portuguesa

Quantidade de aulas: aproximadamente 4 aulas (dependendo da turma)

Público: Estudantes do $5^{\circ}$ e $6^{\circ}$ ano do Ensino Fundamental

OBJETIVOS ALINHADOS COM A BASE NACIONAL COMUM CURRICULAR (BNCC)

Identificar e diferenciar em textos os respectivos sinais de pontuação: a vírgula, ponto e vírgula e os dois-pontos, além da revisão do emprego do sinal de interrogação, exclamação e ponto final.

Objeto de conhecimento: Pontuação.

$5^{\circ}$ ano - Habilidade trabalhada: (EF05LP29)

Diferenciar, na leitura de textos, vírgula, ponto e vírgula, dois-pontos;

Identificar o efeito de sentido do uso de parênteses, reticências e aspas em textos lidos.

Objeto de conhecimento: Pontuação.

$5^{\circ}$ ano - Habilidade trabalhada: (EF05LP30)

Reconhecer, na leitura de textos, o efeito de sentido que decorre do uso de reticências, aspas, parênteses.

$6^{\circ}$ ano - Habilidade trabalhada: (EF67LP33)

Pontuar textos adequadamente;

Realizar leitura com autonomia de texto apresentado. 
Objeto de conhecimento: Apreciação de texto literário.

\section{$5^{\circ}$ ano - Habilidade trabalhada: (EF35LP17)}

Ler, de forma autônoma, textos literários de diferentes gêneros e extensões, inclusive aqueles sem ilustrações, estabelecendo preferências por gêneros, temas, autores.

\section{$6^{\circ}$ ano - Habilidade trabalhada: (EF69LP49)}

Realizar leitura de livros de literatura e de outras produções culturais do campo, sendo receptivo a textos que rompam com seu universo de expectativas e que representem um desafio em relação às suas possibilidades atuais e suas experiências anteriores de leitura, apoiando-se nas marcas linguísticas, em seu conhecimento sobre os gêneros e a temática, de modo a promover a formação leitora.

\section{JUSTIFICATIVA}

Embora na BNCC o texto seja a unidade de trabalho, nem sempre os gêneros textuais trabalhados aproximam-se da realidade do aluno e/ou partem de Centros de interesse, tornando a aprendizagem descontextualizada, fragmentada e sem sentido para os estudantes. Muitas vezes, o professor, ao trabalhar a pontuação, mesmo que utilizando os gêneros textuais, não consegue desenvolver uma atividade que propicie ao aluno um real significado.

A partir desta proposta metodológica desenvolvida por meio da SD pretende-se desenvolver nos alunos uma aprendizagem significativa, ou seja, realizar um processo, o qual possibilite que os estudantes possam ampliar suas experiências com diversos gêneros de texto através da mediação das Tecnologias da Informação e da Comunicação (TIC). Essa mediação é o meio "pelo qual uma nova informação se relaciona, de maneira substantiva (não literal) e não arbitrária, a um aspecto relevante da estrutura cognitiva do indivíduo" (AUSUBEL 2000 apud MOREIRA, 2006, p. 14). Isto quer dizer que, ao se relacionar, os conhecimentos dos alunos aos seus conhecimentos prévios de forma contextualizada a aprendizagem cognitiva adquire um sentido/relevância para os estudantes. 


\section{ENCAMINHAMENTO METODOLÓGICO}

Passo 1: Os alunos receberão, por meio do WhatsApp, os vídeos que contêm a leitura do livro Emocionário. O professor faz a apresentação da obra, que deverá ser ouvida pelos alunos, por meio de acesso ao link disponibilizado anteriormente. Segue ilustração do livro citado:

Figura 1 - Foto ilustrativa do OAD - vídeo com a leitura do livro Emocionário

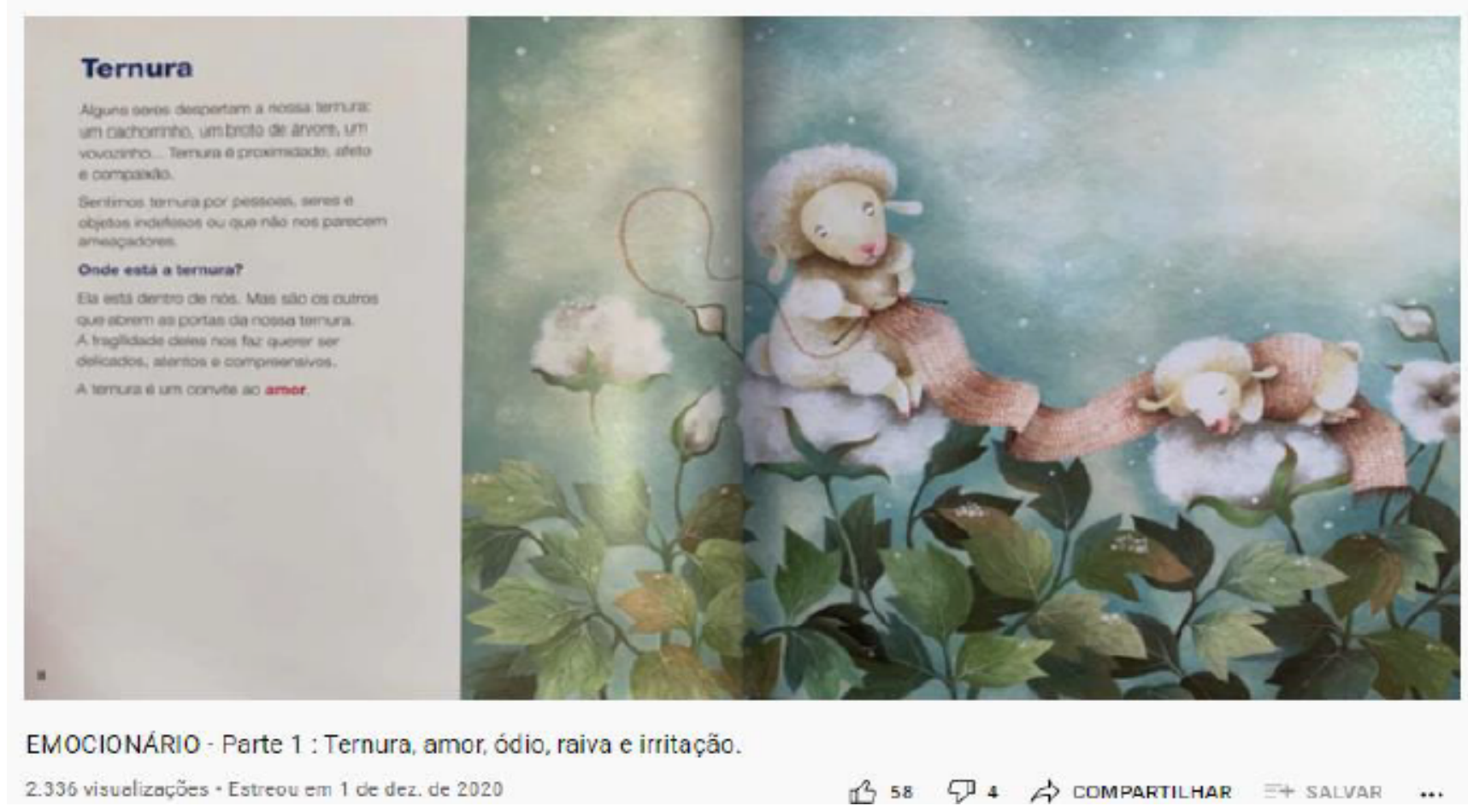

Fonte:<https://www.youtube.com/playlist?list=PLQthYrUcnTEUGhSa5DvwDKuGBbtMcLEy9>.

Passo 2: O professor faz a escuta ativa dos alunos sobre a obra.

Passo 3: É enviado para os alunos o link do segundo OAD, em formato de slide, que fará uma breve revisão do uso da pontuação, conforme é apresentado na imagem a seguir: 
Figura 2 - Foto ilustrativa do OAD - Slide: sinais de pontuação

Inicio Conheça mais

Pesquisar

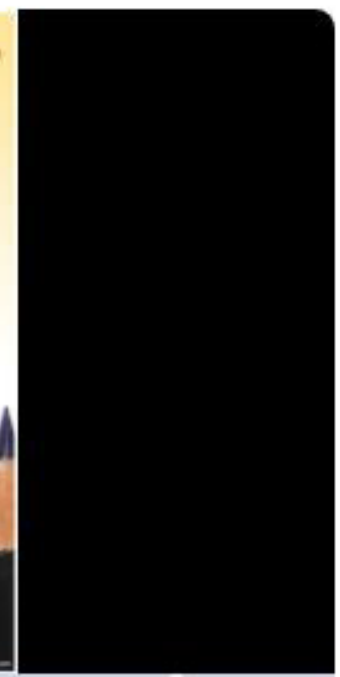

1 de $14>$

Fonte: Alho, 2011.

Passo 4: Apreciação de textos sem a pontuação. O professor envia por meio do WhatsApp textos com diversos gêneros textuais para a leitura, exemplos: notícia, peça teatral, bilhete, convite, receita e outros. No primeiro momento, a turma realiza a leitura dos textos sem a pontuação e, em seguida, com a ajuda do professor fazem a correção coletiva, empregando os sinais de pontuação necessários. De acordo com a imagem a seguir: 
Figura 3: foto ilustrativa do OAD - texto

\begin{tabular}{|c|}
\hline $\begin{array}{c}\text { Texto para pontuar } \\
\text { Copie o texto e coloque os sinais de pontuaçâo corretament } \\
(, \ldots, \ldots l \ldots)\end{array}$ \\
\hline $\begin{array}{l}\text { O bolo de Mariana } \\
\text { Sábado de manha Mariana foi até o supermercado e comprou os } \\
\text { ingredientes para fazer um bolo Mas na hora de fazer o bolo lembrou } \\
\text { que havia esquecido de comprar o fermento. } \\
\text { Ela ficou muito aborrecida e disse para a sua măe } \\
\text { Máe e agora O que vou fazer } \\
\text { Minha filha pense numa soluçäo } \\
\text { Mariana pensou por um instante e até pensou em desistir de fazer } \\
\text { o bolo mas como já havia começado resolveu seguir em frente e fez o } \\
\text { bolo sem o fermento mesmo No hugar do fermento acrescentou muito } \\
\text { carinho e pensamentos positivos } \\
\text { No final da tarde o bolo estava pronto Foi um sucesso } \\
\text { Todos comeram e Mariana ganhou muitos elogios } \\
\text { Ela ficou muito feliz por nầo ter desistido }\end{array}$ \\
\hline
\end{tabular}

Fonte: blog professora Maria, 2012. Disponível em: <https://rpofrosamaria.blogspot. com/2012/10/o-bolo-de-mariana.html?m=0>

Passo 5: A proposta é finalizada com a aplicação de atividade prática, estabelecendo diálogos através das expressões faciais e estabelecendo relações com os sentimentos estudados na obra Emocionário. Os alunos, em duplas ou individualmente, deverão construir um diálogo a partir das expressões fisionômicas recebidas, seguindo a orientação das figuras que seguem: 
Figura 4 - Exemplos de expressões fisionômicas que podem ser usadas
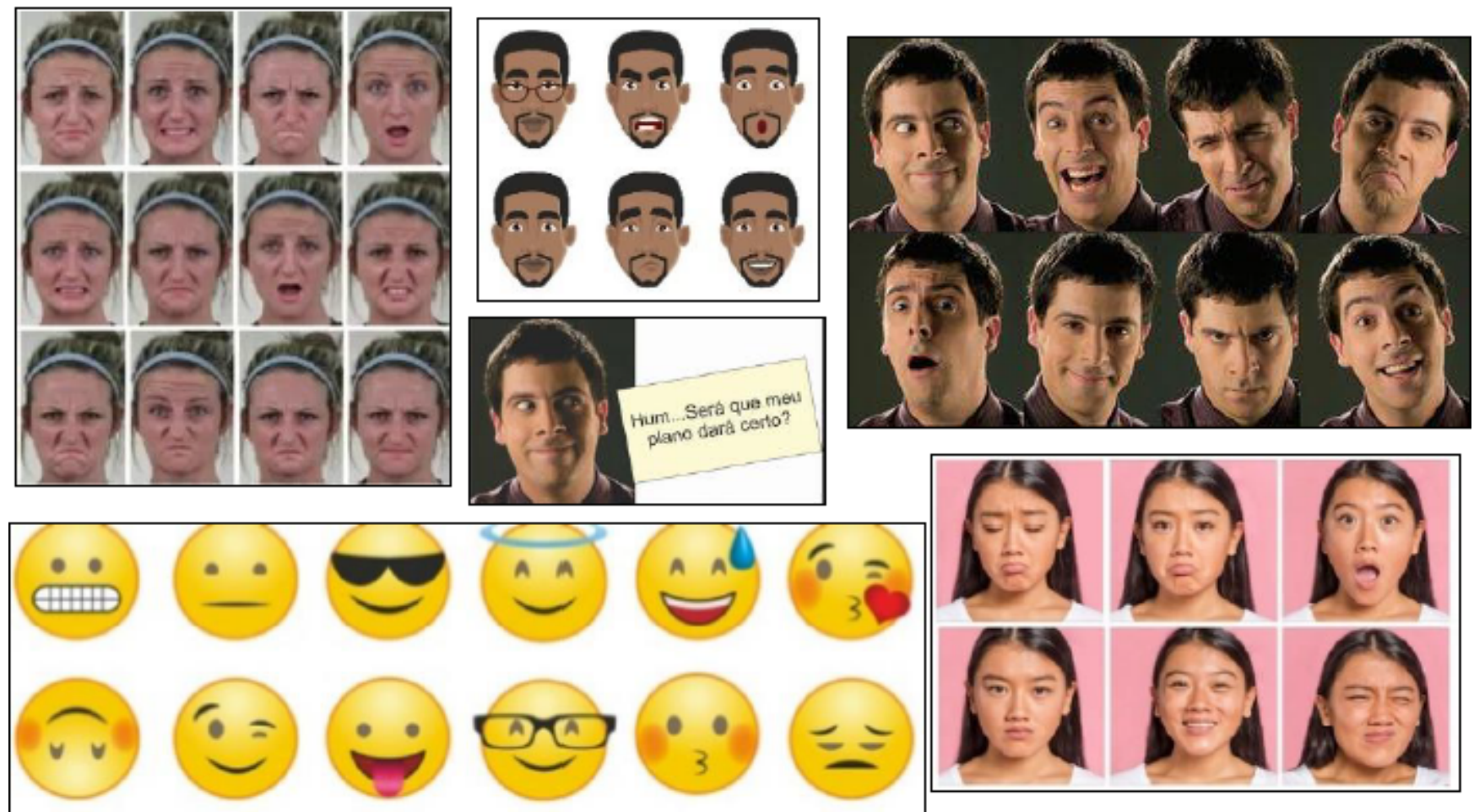

Fonte: <https://www.google.com/search?q=express $\% \mathrm{C} 3 \%$ B5es+fisionomicas>

Passo 6: A avaliação será formativa, Conforme Cardinet (1990 apud BARREIRA et. al., 2006, p.98) "a avaliação formativa é uma modalidade que tem por finalidade orientar o aluno no seu trabalho escolar, procurando identificar e situar as suas dificuldades com a intenção de o ajudar a descobrir modos de progredir na aprendizagem."

Os alunos deverão ser avaliados em todos os aspectos, individualmente e coletivamente. Para isso, os objetivos estabelecidos devem estar claros para professores e alunos, sejam mensuráveis e alcançáveis. Aspectos subjetivos, como participação, autonomia e engajamento não podem ficar fora do processo avaliativo. Outro aspecto que não pode ser relegado é a autoavaliação realizada não só pelos estudantes, mas também pelo professor em sua prática pedagógica.

\section{CONSIDERAÇÕES FINAIS}

A propositura aqui apresentada oportunizou uma reflexão profunda sobre o atual cenário educacional, cujas mudanças constantes refletem os inúmeros 
desafios que precisam ser vencidos quando se busca proporcionar aos alunos não só um aprendizado de qualidade, mas pautado no princípio da equidade. Poucas são as escolas que conseguem atender de forma satisfatória as demandas da nova sociedade, que exige cada vez mais que os alunos se formem como cidadãos analíticos, críticos e aptos para um mercado de trabalho cada vez mais exigente e tecnológico.

A BNCC apresenta uma proposta norteadora para o ensino da Língua Portuguesa pautados no que acreditam ser uma aprendizagem dialógica, criativa, respeitando o conhecimento prévio, proporcionando uma aprendizagem significativa. Nesse contexto, torna-se necessário e importante que os professores busquem realizar suas práticas pedagógicas alinhadas a este documento normativo, sempre buscando perceber a necessidade real de aprendizagem dos estudantes.

Buscou-se, na construção desta proposta metodológica, propiciar uma interação social entre alunos, para uma real construção de sentido para os estudantes. Procurou-se, também, por meio dos objetos de aprendizagem, resgatar os conhecimentos dos alunos sobre pontuação e auxiliar na transição entre o $5^{\circ}$ e o $6^{\circ}$ ano do Ensino Fundamental.

A avaliação da aprendizagem, por vezes, desempenha um papel de extrema importância, não somente nesta metodologia em específico, mas em todo o processo ensino-aprendizagem, possibilitando, assim, o acompanhamento da construção do conhecimento. Desta forma, o trabalho com OAD colabora de forma a oportunizar que o educando possa estar ampliando suas aprendizagens a partir do uso das tecnologias.

\section{REFERENCIAS}

ALHO, J. M. Sinais de pontuação. Slide Share, 2011. Disponível em: <https:// pt.slideshare.net/jose_alho/sinais-de-pontuao>. Acesso em 20 ago. 2021.

ANGULO, R.I.J. et al. Learning Objects. Evolución Histórica. 2006. Disponível em: <https://sites.google.com/site/autoriadecontenidosudl/2100-2104.pdf>. Acesso em 10 set. 2021. 
BARREIRA, C.; BOAVIDA, J.; ARAÚJO, N. Avaliação formativa: novas formas de ensinar e aprender. Revista portuguesa de pedagogia, p. 95-133, 2006. Disponível em: <https://impactum-journals.uc.pt/rppedagogia/article/view/16478614_40-3_4>. Acesso em: 15 jun. 2021.

BEHAR, P. A. O ensino remoto emergencial e a educação à distância. Jornal da Universidade. Disponível em: <https://www.ufrgs.br/coronavirus/base/artigo-o-ensino-remoto-emergencial-e-a-educacao-a-distancia/>. Acesso em: 06. Jun. 2020.

BRASIL. Ministério da Educação. Base Nacional Comum Curricular (BNCC). Brasília, 2017.

BRASIL. Ministério da Educação. Portaria n 343, de 17 de março de 2020. Brasília, DF, 2020.

BRASIL. Ministério da Educação. Conselho Nacional de Educação. Proposta de parecer sobre reorganização dos calendários escolares e realização de atividades pedagógicas não presenciais durante o período de pandemia da COVID-19. 28 de abril de 2020. Brasília, DF, 2020.

CHRISTENSEN, C. M; HORN, M. B; STAKER, H. Ensino Híbrido: uma Inovação Disruptiva? Uma introdução à teoria dos híbridos. Tradução: Fundação Lemann e Instituto Península. 2013. Disponível em: . Acesso em: 19 de maio de 2021.

CINEL, N. C. B. Centros de Interesse: estratégia utiliza multidisciplinaridade para desenvolvimento global. Revista do Professor, Porto Alegre. 2004.

GOMES, L. F. Vídeos Didáticos: uma proposta de critérios para análise. Travessias, Cascavel, v.1 n. 2, p. 40-48. 2002. Disponível em: <http://e-revista.unioeste.br/index.php/travessias/article/view/3128>. Acesso em: 10 set. 2021.

LÉVY, P. Cibercultura. São Paulo: Ed. 34, 1999.

NASCIMENTO, D. Z. L. A importância da apresentação de slides na sala de aula e quando devemos usá-los. Slide Share, 2013. Disponível em: <https://pt.slideshare.net/07zenon/aimportncia-da-apresentao-de-slides-na-sala-de-aula-e-quando-devemos-us-los.> Acesso em 10 set. 2021. 
MOREIRA, M. A. A teoria da aprendizagem significativa e sua implementação em sala de aula. Editora Universidade de Brasília, 2006.

MOORE, M. G; GREG K. Educação a distância: uma visão integrada. [Tradução Roberto Galman]. São Paulo: Cengage Learning, 2008. Disponível em: <https://issuu.com/cengagebrasil/docs/educacao_a_distancia>. Acesso em: 08 jun. 2021.

OLIVEIRA, J. F. A. C. et.al. Educação no contexto da pandemia da Covid-19. Itinerarius Reflectionis, v. 16, n. 1, p. 01-17, 2020. Disponível em: <https://www. redalyc.org/journal/894/89462860100/html/>. Acesso em: 12 out. 2021.

SARAIVA, Karla; TRAVERSINI, Clarice; LOCKMANN, Kamila. A educação em tempos de COVID-19: ensino remoto e exaustão docente. Praxis educativa. vol. 15, 2020. Disponível em: <https://www.redalyc.org/journal/894/89462860100/ html/>. Acesso em: 15 out. 2021.

TAROUCO, L. M. R.; FABRE M. J. M.; TAMUSIUNAS, F. R. Reusabilidade de objetos educacionais. In: RENOTE - Revista Novas Tecnologias para a Educação. Porto Alegre: Centro Interdisciplinar de Novas Tecnologias na Educação (CINTED- UFRGS), v. 1. n 1, 2003. Disponível em: <https://lume.ufrgs.br/ handle/10183//12975>. Acesso em 10 set. 2021.

VYGOTSKY, L. S. A Formação Social da Mente: o desenvolvimento dos processos psicológicos superiores. São Paulo: Martins Fontes, 1984.

VYGOTSKY, L. S. A Construção do Pensamento e da Linguagem. São Paulo: Martins Fontes, 2000.

ZABALA, A. A prática educativa: como ensinar. Porto Alegre: Artmed, 1998. 


\section{do $10.48209 / 978-65-89949-13-1$}

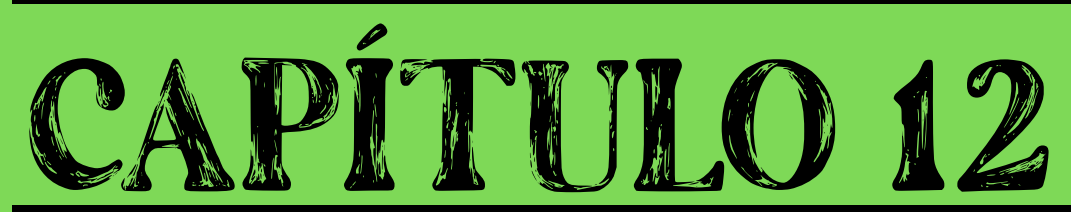

\section{ESCRITA CRÍTICA: A CONSTRUÇÃO DO CORPO ESCRITOR EM LINHAS TRANSVERSAIS EM TEMPO PANDÊMICOS}

Waldenilson Teixeira Ramos 


\section{O PROBLEMA E AS CONTRADIÇÕES}

Neste capítulo, irei relatar as minhas experiências de práticas pedagógicas dentro do campo da escrita e os desafios de efetivar uma práxis de cunho crítico em tempos virais pandêmicos. Elevando o problema pandêmico não só a dimensão da organicidade - biológico/natural -, mas indo de encontro à sua face política - no campo da microfísica do poder, no plano da imanência. Desejo tracejar o problema, então, em sua dimensão macro e micropolítica (DELEUZE; GUATTARI, 2012). Duas dimensões que se atravessam a todo momento, levando a constatação de que tudo é político, inclusive ensino-educação ${ }^{1}$ (FREIRE, 2021).

Para que esta tarefa possa ser feita, irei retomar reflexões da corrente filosófica nomeada por "Filosofia da Diferença" e as grandiosas contribuições do educador brasileiro Paulo Freire em suas obras "Educação como prática de liberdade" e "Pedagogia da Autonomia". Apesar de ter a consciência das possíveis leituras de contradição dessas duas linhas epistemológicas, aqui neste trabalho, me vejo implicado em tecer uma aposta teórica metodológica transdisciplinar. Aposta essa que visa percorrer as tercituradas das reflexões e as inflexões desses polos de pensamentos, estruturalistas e pós-estruturalistas ${ }^{2}$ da filosofia da diferença e a episteme marxista/Paulo freiriana em seu aspecto sócio-construtivista. Também é sabido que os planos onde operam as concepções e análise destas duas vertentes de pensamento se diferem, na corrente da filosofia da diferença se localiza em imanência, enquanto a perspectiva marxista/Paulo frei-

1 Uma das reflexões mais grandiosas do pensamento de Paulo Freire. Uma reflexão de construção contínua do educador durante suas prática pedagógica. O educador nunca está completo ou formado, mas se faz em prática, em seu ensino o educador se educa com seus educandos. Por isso, o pensador dirá com ênfase, não há ensino sem pesquisa, na medida que se ensina se confronta com o mundo e, na mesma medida, pesquisa e ensina. Doravante, se apresenta, então, ensino-educação. Com isso, aí está o que tensiona em práxis - unidade dialética de teoria e prática.

2 Tendo em vista a ampla discussão presente ainda no campo acadêmico a respeito desta linha epistemológica, optei aqui por dar as duas nomenclaturas, estrutural e pós-estrutural. Discussão essa que pode se observar em torno da compreensão do pensamento do filósofo francês Michel Foucault. Enquanto por diversas vezes, em suas aulas e entrevistas, o pensador se apresenta como estruturalista, alguns historiadores insistem em adjetivá-lo como pós-estruturalista a partir de colocações técnicas da história contemporânea. Por isso, mantive as duas posições, de forma a evidenciar também o amplo debate que se perpetua. 
riana em materialismo histórico. Apenas apresentando essas divergências, aqui, já poderíamos dizer que a confecção de um ponto de intersecção é, no mínimo, conflitante. Todavia, é neste mesmo gesto de aposta teórica-metodológica que desejo implicar o problema central deste trabalho, um limiar dentre as reflexões e inflexões. Uma aposta no limite transgressor. A isso nomeio de transdisciplinar gesto transgressor do pensamento e da reflexão. Um processo da pragmática do pensamento de aparente contradição, mas que forja a dialética da experimentação empírica do vivível. Não por um acaso, se nomeia também de aposta.

Colocado o desafio do problema deste trabalho, a confecção das reflexões tangência a experiência pedagógica e as limirielidades dos campos teóricos que sustentam a abordagem teórica deste capítulo. Isso é, como pensar uma práxis pedagógica que vá de encontro com a diferença e propicie espaço de ensino-educação no campo material histórico - onde grandes fundamentos libertinos perpassam a tomada de consciência em direção a transformação do mundo - e a produção de um corpo escritor em devir? Em quais planos essas forças políticas emergem? É possível pensar a emergência dessas forças se dando ao mesmo tempo? Ressaltando o tempo material pandêmico de nossa época e o plano imanente das segmentaridades produtivas de desejo aniquilador da diferença, qual é o papel do educador frente a urgência de educandos críticos e emancipados? Então, aí está o grande problema que desejo pensar nas linhas e entrelinhas deste trabalho.

O material empírico central desta produção advém das minhas experiências enquanto docente no projeto do Grupo de Diversidade Niterói (GDN) ${ }^{3}$, mais especificamente, no setor PreparaEnem; na moradia estudantil UFF/Niterói, no

3 O Grupo Diversidade Niterói surge como fruto de uma longa luta do movimento LGBTQIAP+ no Estado do Rio de Janeiro. O GDN se fundou como ONG de acolhimento às demandas da população trans no centro do Rio de Janeiro, mas se consolidou no município de Niterói, onde encontrou apoio necessário para se consolidar e crescer. Fundado em 24/01/2004, realizador da Parada do Orgulho LGBTI de Niterói e Patrimônio Cultural Imaterial da cidade. Um grupo de Luta. Hoje a ONG realiza diversos projetos pelo Estado do Rio, projetos que visam acolher e atender as pessoas trans em vulnerabilidade econômica, fornecer atendimento psicológico, ensino de caráter pré-vestibular e outros. 
projeto PreparaNós ${ }^{4}$ e de minhas atividades comunitárias e particulares de ensino textual da redação dissertativa-argumentativa ${ }^{5}$. Tais movimentos montaram o cenário da sala de aula presencial e virtual como campo de tensão e construção dos educandos e minha, enquanto educador. A tecnologia da escrita, para além do objetivo direto da comunicação, se apresenta como certo processo reflexivo de si e do mundo, em especial, a tipologia textual dissertativa-argumentativa monta certa diretividade às temáticas políticas de nossa era. Os eixos temáticos dos principais vestibulares e concursos põem em xeque discussões e reflexões a respeito do mundo singular da pessoa e as polaridades das afecções políticas de nosso tempo. O Exame Nacional do Ensino Médio (ENEM), em 2015, exigiu a competência de construir um ponto de vista a respeito da "Persistência da violência contra a mulher na sociedade brasileira", tema não apenas histórico, mas ético-político. Nesse mesmo tônus ético-político e, em última instância estético, que se pôs em esboços de análise reflexiva o nosso tempo, as operações macros e micropolíticas de nosso território brasileiro. Então, para que um aluno pudesse minimamente se posicionar e defender a sua tese, o candidato deveria ter passado por uma construção de um corpo escritor crítico em linhas transversais ${ }^{6}$. Por fim, atento aos desafios que a pandemia apresentou ao mundo, assim como o distanciamento social, se fizeram urgentes o pensar das práticas pedagógicas que se deram no espaço cibernético e nos entraves socioeconômicos.

4 Esse é um projeto não-governamental, apesar de ser realizado em território federativo, o PreparaNós é uma iniciativa exclusiva dos moradores da moradia estudantil UFF/Niterói a fim de compartilhar conhecimento e preparar funcionários terceirizados a serviço da Universidade Federal Fluminense (UFF).

5 Todas as práticas se dirigiam ao preparo dos vestibulares e concursos públicos que tinha com competência exigida de classificação a carta dissertativa-argumentativa.

6 A noção de transversalidade foi cunhada profundamente pelo pensador, psicanalista e ativista Félix Guattari. Tal conceito é fundamental para que pudesse haver uma virada epistêmica nas práticas e análise clínicas da época, ponto em vista crítica aos atravessamentos políticos, econômicos e históricos da subjetividade humana. Ou seja, o autor apresentava outras forças do campo externo e interno que exerciam influência nas práticas terapêuticas da época, práticas que até então vislumbravam pouco os efeitos institucionais na vida e nos sofrimentos relatados por muitos pacientes. Então, se apresentou a necessidade de se observar a horizontalidade da vida sobre o corpo extensivo e intensivo - análise que se direcionava a outras linhas ontológicas. 


\section{PROCESSOS CORPO E MUNDO}

Como atitude de afastamento das supostas posições de neutralidade e universalidade do saber vencedora no ocidente, um corpo pode localizar e expressar sua territorialidade. Essa operação enunciativa de si marca uma ruptura com o modelo de pensamento tão presente na filosofia platônica, cartesiana e kantiana - uma certa corrente de pensamento que engendra o acesso ao conhecimento na representação da razão (DELEUZE; GUATTARI, 2010). Em contrapartida, a aposta ética-metodológica deste trabalho faz o convite a outras práticas para se conhecer a si e o mundo. Consequentemente, isso implica nesse distanciamento do modelo hegemônico de produzir saber, uma cisão de uma racionalidade que se assenta em telos ${ }^{7}$ - ação da razão que se assenta na territorialidade, uma locação sedentária (2010). Doravante, na história do discurso vencedor da episteme filosófica, no ocidente, a máxima desembarcou no famoso dito cartesiano cogito ergo sum - penso logo existo - (DESCARTES, 2005). Um pressuposto que afirma a existência na imagem da racionalidade, certa imagem universal, fora das forças políticas do mundo, sem gênero, corpo ou raça, totalmente alinhado com o sistema de dominação da branquitude e o patriarcado. Aqui encontra-se uma boa motivação, para realizar uma contra força, uma aposta na marcação de um corpo, desterritorializando o pensamento assentado na razão, afirmando que todo discurso advém de um lugar de fala, um corpo impregnado de códigos de gênero, raça, classe e normatividades/desvios. Por isso, este trabalho, necessariamente, se difere de uma ciência positiva, uma forma de conhecer o mundo muito herdeira do método de análise via hiperbólica da dúvida, como presente no pensamento cartesiano.

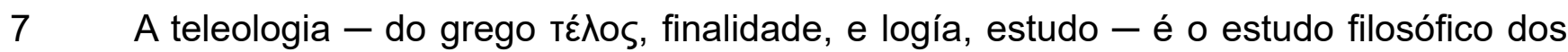
fins, isto é, do propósito, objetivo ou finalidade. Onde a construção ontológica se faz em vias destinatárias. Uma vertente de pensamento profundamente presente na teologia que, em muitas instância, expressa que todas as coisas seguem um propósito e atendem um planejamento, assim como no pensamento cavinistista que defende a pré destinação do ser. Todo Telos é uma representação, uma imagem final para onde se destina a matéria e o espírito e, consequentemente, não há possibilidade de desvios, porque todos os desvios são colocados como parentes escapes, mas todos se encontram prescritos. Aqui encontramos um dos grandes discursos vencedores no pensamento da filosofia ocidental. 
Na forja dos escritos deste trabalho, a marcação da identificação do corpo é fundamental na confecção crítica da discussão que gostaria de propor. Seja enquanto educador que expressa as direções que se fizeram nas práticas pedagógicas ou nas marcações da minha experiência na relação com os educandos, todas as ações foram feitas com um corpo localizado no mundo. Essa indicação é primeira nessa aposta ética, pois aqui o primado é de um corpo que relata e escreve impregnado de história e política, um corpo cheio de mundo e necessariamente no mundo - a minha escrita e dos educandos que tiveram comigo são escrituras imundas ${ }^{8}$. O desejo neste relato é fazer da identidade uma forma de combate ao episteme dominante de nosso tempo - fazer de si uma ferramenta de resistência, abandonando supostas neutralidades e afirmando toda força política e histórica que há em nós - reafirmando a multiplicidade na escrita (DELEUZE, 1997). Todavia, é razoável admitir os riscos das armadilhas que circunscrevem as práticas confessionais cristãs da modernidade. Atento aos riscos dos ditos dos corpos, aí então, encontramos a ação de uma postura parresiasta ${ }^{9}$, localizar onde se enuncia, disputando sua identidade pelo discurso, não como um gesto de culpa, porém como movimento de coragem da verdade (FOUCAULT, 2011). Isso implica dizer, anunciar: "Eu sou um homem preto, cis gênero e em um corpo padrão" é perrigoso, um risco onde a legitimidade de quem fala pode e é colocado no cenário político, encarando a possibilidade de tornar-se um alvo. Basta olhar para a realidade, assim como ela se apresenta, e compreender quem é alvo dos grandes homicídios no país, muitos homicídios executados, inclusive, pelo Estado, pois é o corpo de desvio e este é o objeto da disciplina (2014) em casos mais gerais, a necropolítica. Com isso, posto a dimensão de quem diz, onde diz, como diz e fala a partir de qual corpo, se faz jus a direção da resistência

\footnotetext{
8 Impregnado e encharcado de tudo que há na terra. (In)mundo.

9 "A parresía [...] é portanto uma certa maneira de falar. Mais precisamente, é uma maneira de dizer a verdade. Em terceiro lugar, é uma maneira de dizer a verdade tal que abrimos para nós mesmos um risco pelo próprio fato de dizer a verdade. Em quarto lugar, a parresía é uma maneira de abrir esse risco vinculado ao dizer-a-verdade constituindo-nos de certo modo como parceiro de nós mesmos quando falamos, vinculando-nos ao enunciado da verdade e vinculando-nos à enunciação da verdade. Enfim, a parresía é uma maneira de se vincular a si mesmo no enunciado da verdade, de vincular livremente a si mesmo e na forma de um ato corajoso." (FOUCAULT, 2018).
} 
deste trabalho, porque se toma consciência a que se combate e a urgência do cunho ético e crítico.

Todas as experiências de ensino educação presente aqui, são vivência com corpos marginalizados, este é um relato de um professor preto em relação com estudantes mulheres, travestis, minorias sexuais e pessoas em condições socioeconômicas vulneráveis. Compartilho essas experiências a partir deste mundo. A admissão desse entrelace é o primeiro gesto crítico em ato.

\section{A SALA DE AULA E OS DESAFIOS DO MUNDO}

O quadro pandêmico viral o qual se encontra o mundo atualmente, em virtude da COVID-19, pôs um novo desafio a toda classe trabalhadora. Todos nós fomos acometidos pelos os efeitos diretos e indiretos do enorme entrave sanitário global, e nós educadores enfrentamos uma adversidade inédita frente a necessidade do isolamento social e na prática do ensino/aprendizagem. Quase como resposta imediata ao impasse, o espaço cibernético se apresentou a muitos de nós como uma resposta viável. Talvez, possamos dizer que tal espaço imaterial já estava colocado para muitas (os) das (os) professoras (os) que já se dedicavam ao ensino remoto, com aulas assíncronas ou síncronas. No entanto, essa não parece ser uma resposta possível para aqueles grupos que não despojam do pleno acesso à internet.

Muitas das comunidades do estado do Rio de Janeiro vivem a realidade do domínio das milícias e facções. Esses regimes, por muitas vezes, por exemplo, impedem a entrada das maiores redes de telefonia e de internet em seus territórios e estabelecem os seus próprios serviços de acesso à internet, serviços ilegais em sua maioria e de baixa qualidade. Nesse contexto, um primeiro empecilho se presentifica, milhares de pessoas sem o acesso à internet ou, quando encontram as vias para acessá-las, a utilizam com baixa qualidade. Esse foi um dos impasses que encontrei na minha jornada com algumas alunas trans/travestis, no projeto PreparaEnem da ONG GDN. Nesse cenário se encontra fortemente presente na periferia da cidade do Rio de Janeiro, "Traficantes e milicianos 
estão interrompendo o serviço de internet de moradores e assumindo o controle da distribuição de sinal em várias regiões do Rio de Janeiro." (REGUEIRA, 2020). Esse retrato faz com que o seguinte relato seja corriqueiro:

"O dono dessa internet que tá aqui, agora, é da milícia! Eles [os milicianos] tiraram as outras que estavam aqui dentro. Tinha outras operadoras aqui dentro. Tudo legalizado, direitinho, e eles tiraram o cara porque eles queriam que os "cara" pagassem R\$ 32 mil por mês pra eles ficarem aqui”, denunciou um morador que pediu para não ser identificado. (2020)

A inacessibilidade a uma interde qualidade foi um fator de evasão muito significativo às atividades educacionais que visam o atendimento a pessoas mais necessitadas. Em 2020 a prefeitura de Niterói, em parceria ao Grupo de Diversidade Niterói, contemplou em torno de 30 (trinta) alunes que eram atendidos pela instituição, com tablets e chips de telefonia com acesso à internet durante um ano, além do acesso a plataforma de ensino Descomplica. O benefício foi direcionado às pessoas "T" - Trans, travestis e transgênero - e outras pessoas dentro e fora da comunidade LGBTQIAP+ também foram beneficiadas. Contudo, mesmo as poucas pessoas que receberam o benefício tiveram outros entraves com relação ao progresso de suas formações, em especial tal grupo de pessoas.

A realidade das pessoas T sempre foi dura - marcada pelo enfrentamentos de uma série de estigmas, transfobia e a colocação de seus corpos como grandes alvos de aniquilamento - e, durante todo o período pandêmico, a dificuldade do mundo seguiu sendo pesada. Muitas das disciplinas que são necessárias para um bom desempenho no vestibular, especialmente quando o próprio educador não aposta sua prática em vias críticas, podem ser apresentadas de forma um tanto quanto afastada dos grandes temas políticos de nossa era. De uma certa forma, as discussões a respeito dos grandes eixos temáticos na redação dos principais vestibulares tocam de forma direta assunto políticos em disputa na realidade brasileira. O ENEM já cobrou os seguintes temas: "A persistência da violência feminina na sociedade brasileira" em 2015; "Os caminhos para se combater o racismo no Brasil" em 2016; "Desafios para a formação educacional de surdos no Brasil" em 2017; "Manipulação do comportamento do usuário pelo con- 
trole de dados na internet" em 2018; "Democratização do acesso ao cinema no Brasil" em 2019 e, o mais recente "O estigma associado às doenças mentais na sociedade brasileira" em 2020. Há anos os temas de redação são problemáticas de frutos históricos, políticos e sociais e, para que a estudante possa minimamente construir uma carta dissertativa-argumentativa interessante, é necessário visão crítica do mundo. Então, o docente de redação precisa ter em seus anseios a direção de construir um espaço de sala de aula transversal, onde o educando possa se tornar enquanto sujeito em seu tempo, tomando consciência dos temas de sua sociedade e tempo. Para que esse espaço de aula possa ser construído é fundamento a tomada da palavra desses mesmos temas, onde a aluna anuncia e debate sobre suas perspectivas e, assim, possa fortalecer as bases de seu pensamento. Nesse mesmo cenário, pandêmico e cibernético, onde desejei construir uma prática de ensino afastada do bancarismo, constatei o enorme desafio de falar das pessoas "T" em seus lares conservadores e opressores. Muitas das estudantes que tiveram comigo relataram que preferiam não falar de assuntos mais delicados e os temas que iam de encontro a visão conservadora, por conta da possibilidade de escuta de seus pais. A sala virtual nunca foi capaz de fornecer um espaço seguro de debate, em especial, aos corpos mais martirizados.

Por muitas vezes, minhas falas eram marcadas por um gelo, um congelar que atravessava a mim e, principalmente, as discentes que se colocavam a me ouvir. Todavia, esse era um desafio não só de enunciação de conteúdo reflexivo do mundo, mas uma jornada parresiasta (FOUCAULT, 2011). Por um outro lado, essa mesma condição me colocava nas fronteiras do ensino bancário (FREIRE, 2021), e, eram naqueles momentos, que me observava na direção da redução de tudo que o ensino-educação pode proporcionar e afirmava o problema bancarismo:

"bancário", que deforma a necessária criatividade do educando e do educador, o educando a ele sujeitado pode, não por causa do conteúdo cujo "conhecimento" Ihe foi transferido, mas por causa do processo mesmo de aprender, dar, como se diz na linguagem popular, a volta por cima e superar o autoritarismo e o erro epistemológico do "bancarismo". (P.16). 
Ainda que sobre as periculosidades do dizer em linhas parresiastas e nos possíveis desvios de uma prática pedagógica crítica e libertina, se foi urgente refletir acerca dos restos: o que me restava a fazer no isolamento social? O que me resta para construir um lugar de fala crítica e libertadora? O que me resta frente ao risco de dizer? Defronte ao combate do fascismo tão presente em sua face molecular (DELEUZE; GUATTARI, 2010), restava o gesto escrito. O que eu e aqueles corpos poderíamos fazer nesse cenário era escrever, aposta numa escrita que corte o real e mutilasse as vísceras, as bocas e as cartilagens do mundo político engendrado pela lógica mortífera da diferença (MARTINS, 2017). Doravante, a aposta se fez em escrever criticamente e expressando o que havia em nós e com a força insurgente que havia dentro de nós, juntos, assim seguimos.

O necessário é que, subordinado, embora, à prática "bancária", o educando mantenha vivo em si o gosto da rebeldia que, aguçando sua curiosidade e estimulando sua capacidade de arriscar-se, de aventurar-se, de certa forma o "imuniza" contra o poder apassivador do "bancarismo". Neste caso, é a força criadora do aprender de que fazem parte a comparação, a repetição, a constatação, a dúvida rebelde, a curiosidade não facilmente satisfeita, que supera os efeitos negativos do falso ensinar. (p.16).

\section{TROCAS DE CORRESPONDÊNCIAS OS GESTOS DAS CARTAS}

A carta dissertativa-argumentativa é um texto escrito na modalidade de prosa, em linhas gerais, tem como objetivo primário convencer o leitor do ponto de vista do escritor. O ensino do convencimento é uma pedagogia no mínimo arriscada nos espaços de horizontalidade e crítica - onde se visa a construção de uma classe emancipada das lógicas autoritárias. Todavia, a fim de ir para além dos sentidos já colocados, fizemos em coletivo um sistema de correspondências dessas cartas, onde o objetivo geral não era o convencimento, porém, a troca. Nesse mesmo esquema, o desejo era expressa em vias escritas aquilo que não poderia ser dito em muitos lugares e compartilhar com o outro o processo de desenvolvimento da escrita. Por isso, o gesto das cartas eram transversais - linhas 
de subjetivação atravessadas por muitas forças políticas, forças de opressão externas e forças insurgentes internas. O campo de transversalidades estava colocado, todas podiam ler e escrever as cartas umas das outras. Todas poderiam se posicionar contra ou a favor das cartas uma das outras, realizar explicações a respeito da estrutura padrão dessa tipologia textual e apropriar a palavra em outras vias. Aqui eu encontrei a única educação possível, onde o ser humano se toma como sujeito, onde o homem não é uma condição das ficções de gênero, mas autônomo.

Se esta educação só é possível enquanto compromete o educando como homem concreto, ao mesmo tempo o prepara para a crítica das alternativas apresentadas pelas elites e dá-lhe a possibilidade de escolher seu próprio caminho. (FREIRE, 1967. p.23).

Como apresentação de material empírico dessa experiência, compartilharei algumas redações confeccionadas por mim. Todavia, não apresentarei as cartas feitas pelas estudantes, visto a necessidade ética de consultá-las para tal exposição, gesto que não pude realizar à tempo deste escrito. As escritas que tangenciam a minha vivência corpórea foram feitas sobre o problema sócio-político do racismo estrutural e a vida na periferia. As duas redações a seguir foram feitas em resposta ao vestibular ENEM e o concurso militar AFA ${ }^{10}$.

\section{"REDAÇÃO"}

Tema: Os caminhos para combater a intolerância racial no Brasil (ENEM 2016; $2^{\circ}$ aplicação)

Autor: Waldenilson T. Ramos

“Existem muitas coisas que não te disseram na escola. Cota não é esmola. Experimente nascer preto na favela, para você ver. O que rola com preto e pobre não aparece na TV. Opressão, humilhação, preconceito. A gente sabe como termina quando começa desse jeito.”. Essas são as palavras da artista e militante negra, Bia Ferreira. Esta artista busca explicitar a realidade através de suas composições. Para além de belas canções, suas músicas chocam e conscientizam

$10 \quad$ Academia da Força Aérea. 
muitas pessoas. Certamente, este é um dos muitos caminhos para se combater a intolerância racial no Brasil. No entanto, se faz necessário trilhar também outros caminhos, para que se possa vencer nesta luta. A educação e a política, por exemplo, são outros belos caminhos e importantes, frente ao problema.

Em primeiro lugar, é preciso compreender que a educação é a matriz formadora de uma sociedade, isto implica dizer que os indivíduos de uma civilização são reflexos de sua cultura e educação. Tendo como máxima a afirmação de Emmanuel Kant: "O ser humano é aquilo que a educação faz dele.", é imprescindível um olhar direcionado à educação e reconhecer sua suma importância. Contudo observa-se no Brasil uma educação que pouco se direciona ao combate do racismo, já que o tecido social ainda se encontra nesse impasse. Por isso, a educação deveria ser uma ferramenta mais utilizada nesta guerra.

Outrossim, as relações de poder que gerem o Brasil são fundamentais, para que a sociedade alcance, finalmente, a vitória neste combate. No entanto, falham como os principais agentes de luta, já que historicamente estabeleceu-se pautado no sistema escravista. Visto que o governo precisa ser o principal agente combatedor da intolerância no país, pois segundo Thomas Hobbes: "O homem é lobo do homem.", nesta relação o Estado precisa ser forte como um Leviatã - forte o suficiente para apaziguar a natureza conflitante dos homens. Contudo a história da política brasileira é profundamente marcada por um sistema que legitimou fielmente as relações de escravização, esta ação deixou marcas na sociedade brasileira até a atualidade. Por isso a política atual precisa reconhecer e compreender sua história, para que daqui em diante novas posições possam ser tomadas. Consequentemente, assim afastará a civilização brasileira do terrível quadro social, que uma vez fez - e faz - parte da sua realidade.

Fica evidente, portanto, que a sociedade brasileira se encontra em um grande impasse; e que a educação e a política são ótimos meios para combater a intolerância racial no Brasil. Mas, para tanto, novas posições precisam ser tomadas nessas esferas. Bom seria que as políticas do Ministério da Educação e da Cultura (MEC) fossem aperfeiçoadas. Por exemplo, estipulando disciplinas obriga- 
tórias ao ensino médio de consciência social, étnico e racial; Aulas que devem ser ministradas por professores e militantes negros, para que um novo referencial se construa aos alunos em uma conscientização eficaz. Já que, segundo Paulo Freire, "Educação não transforma o mundo. Educação muda pessoas. Pessoas transformam o mundo.".

"UMA IMAGEM, MAIS DE MIL MORTOS"

Tema: A realidade da vida nas favelas e a maneira como são apresentadas atualmente para o mundo. - AFA 2016

Autor: Waldenilson T. Ramos

"Aquela Campanha de Canudos lembra um refluxo para o passado. E foi, na significação integral da palavra, um crime. Denunciemo-lo" - palavras segundo Euclides da Cunha. Tal afirmação foi feita pelo jornalista que desejou combater uma apresentação infame que, em última instância, gerou injúrias e uma guerra, a guerra de Canudos. Analogamente, as favelas brasileiras são uns dos muitos alvos de produções imagéticas estereotipadas no Brasil. Esse cenário é fruto dos meios de comunicação que massiva uma determinada visão e, por consequência, fazem surgir uma violência fomentada.

Primeiramente, os meios de propagação de informação são os principais agentes de uma apresentação das favelas nociva à sociedade, já que a deixa indiferente. Tendo em vista a produção massiva que os meios de comunicação fazem de uma visão que dá notoriedade apenas a violência. Assim, é certo que nossa sociedade está cada vez mais insensível a violência operante nos morros. Porque, segundo Hannah Arendt, ações brutais podem ser naturalizadas pela repetição. Por causa disso, a produção em massa de uma apresentação exclusivamente da violência nas favelas é um impasse na contemporaneidade, pois insensibiliza as pessoas. Ademais, por intermédio dessa insensibilidade, a violência nas favelas é fomen- 
tada. Visto que cerca de $60 \%$ da população brasileira concorda com a expressão: "Bandido bom é bandido morto.", segundo Fórum Brasileiro de Segurança Pública. Observa-se, portanto, que no imaginário brasileiro, em certas condições, uma morte pode não ter significância alguma. Além disso, nesse cenário, os bandidos são designados, de forma generalizada, aos moradores de favela. Pois é nítido que a mesma leitura não é feita aos políticos corruptos, bandido bom é bandido morto, mas só quando é bandido de favela. Frente a isso, é certo que a insensibilidade à violência nas favelas é um impasse que, por consequência, legítima a morte de milhares. Assim, banido ou não bandido, só se faz necessário ser apresentado como indigno à vida para que se possa morrer sem clemências.

Com isso, fica evidente que a apresentação das favelas está entrelaçada à forma em que ela é apresentada a nós. Não distante da história de Canudos durante a república oligárquica, as comunidades têm vivido uma realidade de guerra. Da mesma maneira que se tinha uma visão estereotipada dos moradores do nordeste da Bahia no final do século XIX, os civis que moram nas periferias dos centros urbanos vivem a calamidade da violência cotidiana e da produção imagética que os segregam de uma vida digna.

\section{CORPO ESCRITOR CRÍTICO}

Essas experiências marcaram o início da minha prática pedagógica no contexto pandêmico. Um processo que apresentou a entrada de uma jornada desafiadora, em novos contextos materiais e de novas possibilidades inventivas de vínculo com os educandos. Todas essas dimensões seguiram atravessadas pela escrita na direção da criticidade da história e do mundo.

Em outros momentos, com outros estudantes, outros contextos e desafios temáticos se apresentaram em minhas práticas, assim como muitos sucessos, a exemplo, a vitória de educandas aprovadas em vestibulares e homens pretos aprovados nos concursos militares. Todas essas pessoas que passaram por mim 
muito me ensinaram e muitas coisas eu pude trocar com elas, legitimando a aposta primária do ensino-educação.

Seja onde for que esses educandos estejam, em um momento ou outro, recebo notícias de suas jornadas. Anexo às suas mensagens, o caráter constitutivo da crítica e o olhar questionador se apresentam como inexoráveis em seus corpos. Aqueles que seguem carreira militar talvez tenham encontrado os maiores impasses frente suas formações, no entanto em suas passagens de ensino aprendizagem junto comigo a autonomia se fez élo chave de ensino. Pois "o respeito à autonomia e à dignidade de cada um é um imperativo ético e não um favor que podemos ou não conceder aos outros." (Freire, 2021, p. 59).

Por fim, constata-se que a construção de um corpo escritor só pode se dá em vias transversas, onde se abandona o bancarismo e a processo ensino-educação é a dialética da pesquisação do educador, sempre forjando ao lado de seus companheira de sala de aula práticas de tomada de si como sujeito consciente das temáticas de seu tempo (2021). O corpo escritor crítico não se alinha às formações autoritárias e hierárquicas, onde a força disciplinadora é engrenagem central e produtora de docilização dos corpos (FOUCAULT, 2014). Assim, as atitudes reivindicatórias não se dão por um suposto saber, mas pela autorreflexão - "Auto-reflexão que as levará ao aprofundamento consequente de sua tomada de consciência e de que resultará sua inserção na História, não mais como espectadoras, mas como figurantes e autoras." (FREIRE, 1967, p.36).

\section{REFERÊNCIAS}

DESCARTE, René. Discurso do método: 458. 1. ed. Editora. L\&PM; Edição de bolso, 2005.

DELEUZE, Gilles. Crítica e clínica. 1. ed. Editora 34, 1997.

DELEUZE, Gilles; GUATTARI, Félix. Mil platôs - capitalismo e esquizofrenia, vol. 3. 2. ed. Editora. 34, 2012.

DELEUZE, Gilles; GUATTARI, Félix. O anti-édipo. 2. ed. Editora 34, 2011. 
DELEUZE, Gilles; GUATTARI, Félix. O que é filosofia? 3. ed. Editora. 34, 2010.

FOUCAULT, Michel. A coragem da verdade. 1. ed. Editora. WMF Martins Fontes, 2011.

FOUCAULT, Michel. O governo de si e dos outros. 4. ed. Editora. WMF Martins Fontes, 2018.

FOUCAULT, Michel. Vigiar e punir. 1. ed. Editora. WMF Martins Fontes, 2014.

FREIRE, Paulo. Educação como prática de liberdade. 1. ed. Editora. Paz \& Terra, 1967.

FREIRE, Paulo. Pedagogia da Autonomia. 1. ed. Editora. Paz \& Terra, 2021.

MARTINS, Beatriz Adura. Por uma escrita dos restos: 0 encontro entre a psicologia e os assassinatos de travestis. 1. ed. Editora. Gramma, 2017.

REGUEIRA, Chico. Traficantes e milicianos cortam internet de moradores no RJ para cobrar pelo serviço. G1 - Rio de Janeiro. 20 out. 2020. Disponível em: <https://g1.globo.com/rj/rio-de-janeiro/noticia/2020/10/20/traficantes-e-milicianos-cortam-internet-de-moradores-no-rj-para-cobrar-pelo-servico.ghtml>. Acesso em 05 outubro 2021. 


\section{SOBRE OS ORGANIZADORES}

\section{ROSIELE OLIVEIRA DA ENGARNAÇÃO}

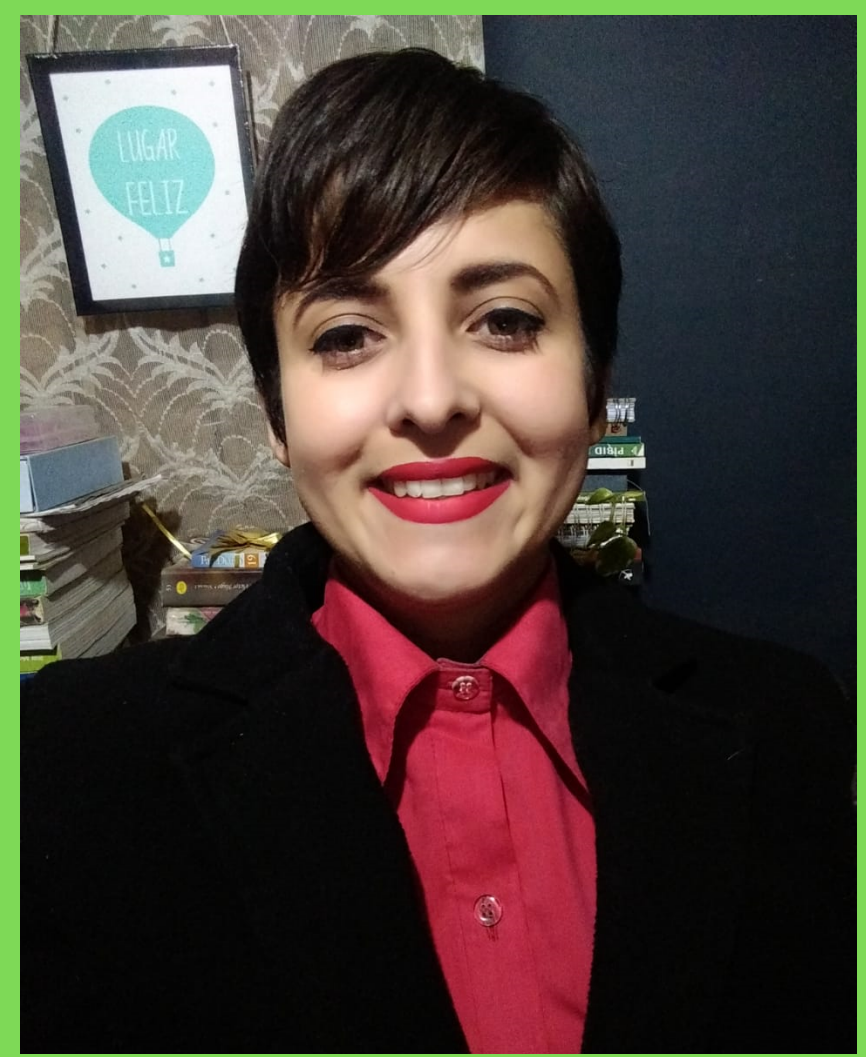

Doutoranda no Programa de Pós-Graduação em Educação em Ciências: Química da Vida e Saúde da Universidade Federal de Santa Maria (UFSM). Mestre em Educação em Ciências pela Universidade Federal de Santa Maria (UFSM). Licenciada em Ciências Biológicas (2015) e Técnica em Informática (2017) no Instituto Federal Farroupilha - Campus São Vicente do Sul. Atualmente é professora instrutora no Programa Temas Emergentes e Ensino Híbrido para Educação Básica da Universidade Federal de Santa Maria (UFSM).

Link do Lattes: http://lattes.cnpq.br/0029263731164716

Orcid: https://orcid.org/0000-0002-4314-5897 


\section{REIGIANE CANABARRO DREHMER-MARQUES}

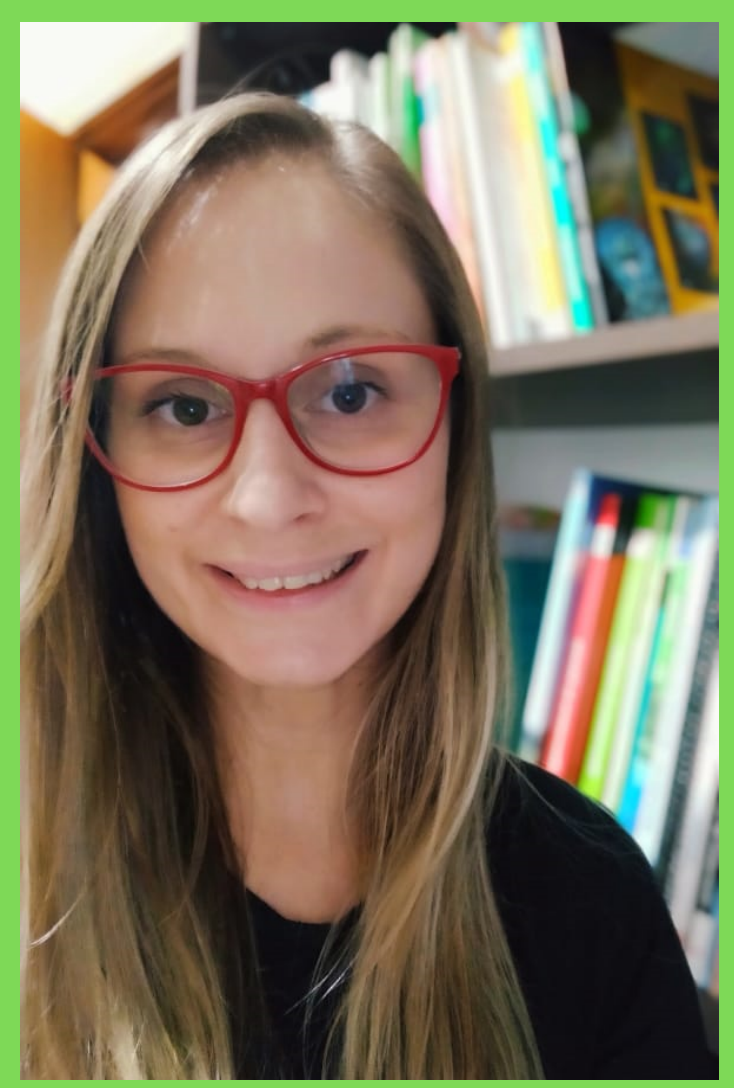

Doutora em Educação em Ciências pela Universidade Federal de Santa Maria -UFSM (2020). Mestra em Educação em Ciências (2016), Especialista em Educação do campo (2021), licenciada em Ciências Biológicas (2012) e bacharela em Ciências Biológicas-UFSM (2019) . Tem experiência na área de formação de professores, Tecnologias de Informação e Comunicação (TIC), Educação a Distância (EaD), Ensino de Ciências/ Biologia/Ciências da Natureza e interdisciplinaridade. Técnica em biologia na Universidade Federal de Santa Maria.

Link do Lattes: http://lattes.cnpq.br/5945107541255759

Orcid: https://orcid.org/0000-0002-5338-8534 


\section{JOSE FRANGISCO ZAVAGLIA MARQUES}

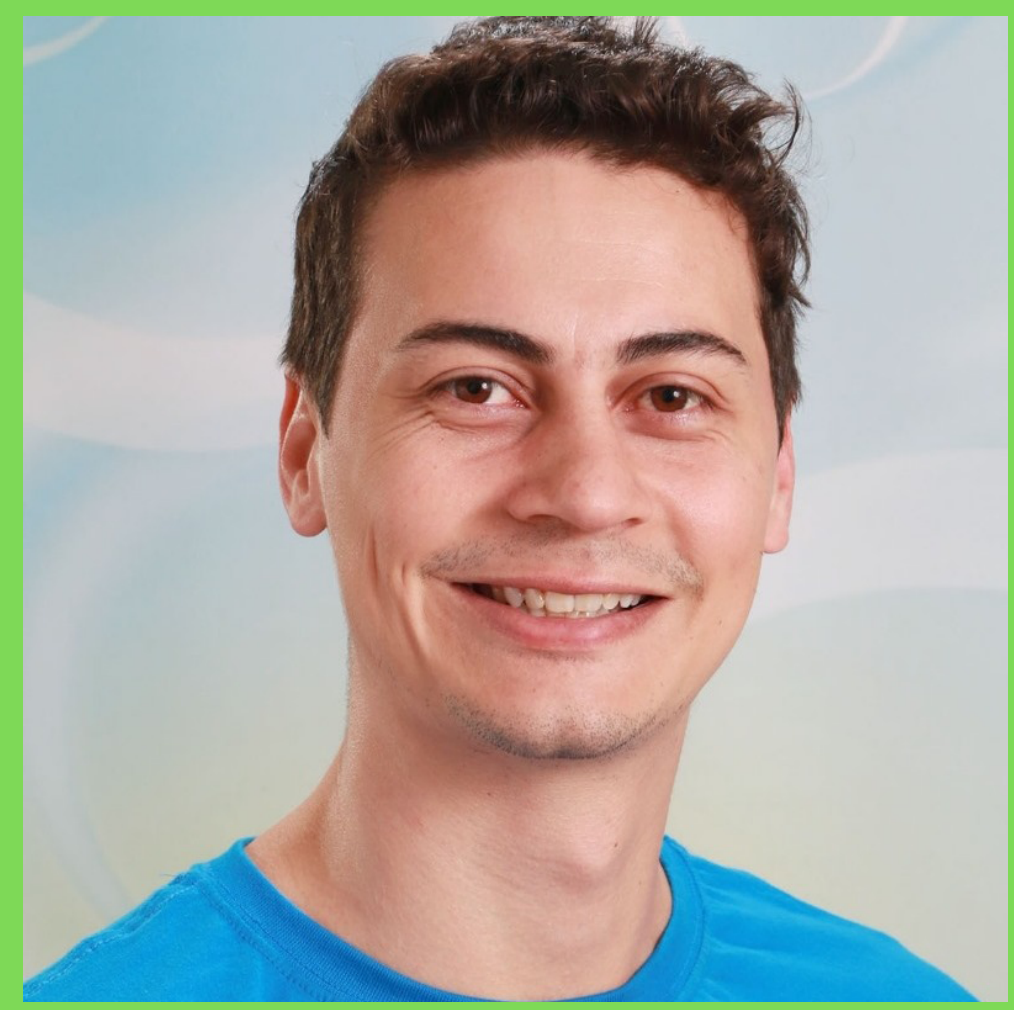

Doutorando em Educação em Ciências na Universidade Federal de Santa Maria (UFSM). Mestre em Nanociências pela Universidade Franciscana (UFN), Especialista em Educação Ambiental (UFSM) e Licenciado em Química pela Universidade de Cruz Alta (UNICRUZ). Tem experiência em metodologias ativas no Ensino de Química/ Ciências da Natureza e TIC como ferramentas de apoio ao ensino. Participa como membro de comissões avaliadoras de projetos e Feiras de Ciências da Educação Básica, orientou trabalhos de Iniciação Científica da Educação Básica na área de Ciências da Natureza. Atualmente é Técnico em Laboratório de Química da Universidade Federal do Rio Grande do Sul (UFRGS).

Link do Lattes: http://lattes.cnpq.br/1032350487311387

Orcid: https://orcid.org/0000-0002-7866-112X 


\section{LIZIANY MŨLLER}

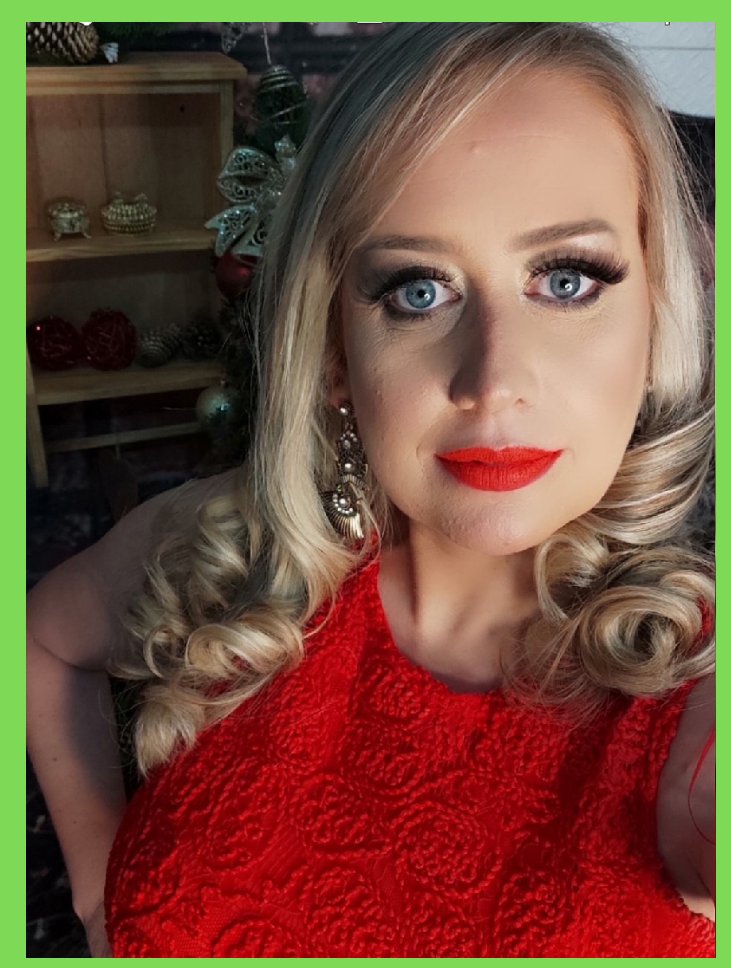

Possui Bacharelado em Zootecnia (2004) e Licenciatura pelo Programa Especial de Graduação de Formação de Professores para a Educação Profissional (2011) ambas pela Universidade Federal de Santa Maria, Mestrado (2006) e Doutorado (2009) pelo Programa de Pós Graduação em Agronomia na Universidade Federal de Santa Maria, Pós-doutorado em Zootecnia no Programa de Pós Graduação em Zootecnia na Universidade Federal de Santa Maria (2011). Atualmente é professora Associada II, responsável pelo Laboratório Mediações Sociais e Culturais - Departamento de Educação Agrícola e Extensão Rural - Centro de Ciências Rurais - Universidade Federal de Santa Maria; Professora e Coordenadora do Curso de Licenciatura em Educação do Campo da Universidade Aberta do Brasil/UFSM; Professora Permanente no Programa de Pós-Graduação em Extensão Rural. Também coordena a ação de Extensão-Fiex/CCR/ UFSM “Programa de Capacitações Temas Emergentes e Ensino Hibrido para Educação Básica” e o grupo de pesquisa registrado no CNPq “Girassol” Grupo de Pesquisa em Agroecologia, Educação e Inovações Sociais”.

Link do Lattes: http://lattes.cnpq.br/1486004582806497

Orcid: https://orcid.org/0000-0001-7325-6611 


\section{SOBRE AS AUTORAS E OS AUTORES}

\section{Aline Kerber Bruniczak}

Licenciada em Pedagogia - Uninter Educacional SA - UNINTER/PR e Educação Física - Universidade Luterana do Brasil - ULBRA/RS. Especialista em Supervisão Escolar e Orientação Educacional - UNINTER/RS, Especialista em Alfabetização - BARÃO DE MAUÁ e Especialista em Neuropsicopedagogia - UNINTER/RS. Mestranda em Letras - Universidade Santa Cruz do Sul - UNISC/RSProfessora da Rede Pública Municipal de Montenegro/RS.

E-mail: akbruniczak@mx2.unisc.br

\section{Antônio Amadeus Mendes Gonçalves}

Graduando em Licenciatura em Física pelo IFPI Campus Picos.

E-mail: antonioamadeus060@gmail.com

\section{Antônio Rodrigo Delepiane de Vit}

Doutor em Ciência da Computação pela PUC-RS (Pontifícia Universidade Católica do Rio Grande do Sul). Professor Adjunto do Departamento de Tecnologia da Informação da UFSM (Universidade Federal de Santa Maria) - Campus Frederico Westphalen/RS.

E-mail: rodrigodevit@inf.ufsm.br

\section{Cícero Antonio Jatanael da Silva Tavares}

Mestrando do Programa de Pós-Graduação em Geografia da Universidade Federal da Paraíba.

E-mail: jatanael.s@gmail.com

\section{Darlize Déglan Borges Beulck Bender}

Ciências Biológicas (URCAMP), Mestre em Ciências Biológicas (UNIPAMPA), Doutoranda em Educação em Ciências (PPGECQVS/UFSM).

E-mail: darlizebender@gmail.com

\section{Flávio José de Carvalho Sousa}

Graduando em Licenciatura em Física pelo IFPI Campus Picos.

E-mail: flaviojosefj07@gmail.com 


\section{Haroldo Reis Alves de Macêdo}

Doutor em ciência e engenharia de materiais. Professor do IFPI Campus Picos. E-mail: haroldoram@ifpi.edu.br

\section{Ítalo Marcos de Lima}

Mestre em ensino de física. Grupo de pesquisa em Ensino de Física do IFPI Campus Picos. E-mail: profitalolima@hotmail.com

\section{Jaqueline Estácio Barbosa de Jesus Santos}

Doutoranda e Mestra em Língua e Cultura (UFBA); Graduada em Letras Vernáculas (UFBA); Pesquisadora do Núcleo de Pesquisa do Discurso - Nuped (UFBA); Especializada em Psicopedagogia (FSBA); Graduada em Normal Superior/ Educação Infantil - (FSBA); Experiências na sala da de aula, na rede pública e privada, desde a educação infantil até o ensino médio. Colaboradora da Biblioteca Comunitária Paulo Freire, local em que atua como coordenadora pedagógica, mediadora de leitura com ações de fomento à leitura, formação de leitores e mediadores. e-mail: jaquestacio28@yahoo.com.br

\section{Joice Vareiro da Costa Brites}

Pós graduada em Educação Especial e graduada em Pedagoga.

E-mail: Joice.vareiro@hotmail.com

\section{Janilse. F. Nunes}

UFN/PPGCIMAT/Docente. E-mail: janilse@prof.edu.ufn.br

\section{José Francisco Zavaglia Marques}

Técnico em Química na UFRGS, Doutorando em Educação em Ciências (UFSM), Mestre em Nanociências (UFN), Especialista em Educação Ambiental (UFSM) e Graduado em Química Licenciatura (UNICRUZ).

E-mail: franciscoquimica12@gmail.com

\section{Keiciane Canabarro Drehmer-Marques}

Técnica em Biologia na UFSM, Doutora em Educação em Ciências (UFSM), Mestra em Educação em Ciências (UFSM), Especialista em Educação do Campo (ICETEC), Licenciada e Bacharela em Ciências Biológicas (UFSM).

E-mail:keicibio@gmail.com

\section{Luciane M. Schlottfeldt}

UFN/PPGCIMAT/Doutoranda. E-mail: luciane_schlottfeldt@yahoo.com.br 


\section{Luana Ehle Joras}

Ciências Biológicas (UFSM), Mestre e Doutoranda em Educação em Ciências (PPGECQVS/UFSM). E-mail: luanaehlejoras@gmail.com.

\section{Liziany Müller}

Doutora em Agronomia, professora do Departamento de Educação Agrícola e Extensão Rural na UFSM. E-mail: lizianym@hotmail.com.

\section{Laercio Fernandes dos Santos}

Doutorando em Letras - Linguística (UPF). Mestre em Letras - Linguística pela Universidade de Passo Fundo, RS, Brasil. Professor de Língua Portuguesa há 25 anos. Formado em Letras pela Universidade de Passo Fundo, Especialização em Pedagogia Social (UPF/RS). Metodologia do Ensino de Literatura e Língua Portuguesa, Docência no Ensino Superior, Arte e Educação pelo Centro Universitário Leonardo da Vinci (UNIASSELVI, SC, Brasil). laerciofsanto@hotmail.com.

\section{Priscilla Basmage Lemos Drulis}

Mestre em Educação pela UEMS; Pós graduada em Educação Especial, Psicopedagogia clínica e institucional; Gestão, coordenação e supervisão escolar. Graduada em `Pedagogia. E-mail: pribasmage@hotmail.com.

\section{Rosiele Oliveira da Encarnação}

Doutoranda em Educação em Ciências (UFSM), Mestra em Educação em Ciências (UFSM) e Licenciada em Ciências Biológicas pelo IFFar.

E-mail: rosiele.oliveira.encarnacao@gmail.com.

\section{Raiane da Rosa Dutra}

Doutoranda em Educação em Ciências (UFSM), Mestra em Educação em Ciências (UFSM) e Licenciada em Ciências Biológicas pelo IFFar.

E-mail: raiane.rosa.dutra@gmail.com.

\section{Sidnei Renato Silveira}

Doutor em Ciência da Computação pela UFRGS (Universidade Federal do Rio Grande do Sul). Professor Associado do Departamento de Tecnologia da Informação da UFSM (Universidade Federal de Santa Maria) - Campus Frederico Westphalen/RS. E-mail: sidneirenato.silveira@gmail.com 


\section{Thayane Azevedo Pereira de Souza}

Professora de Educação Especial, mestranda em Educação - PPGE UFF. E-mail: profthayaneazevedo@gmail.com.

\section{Walter Duarte Monteiro Neto}

Licenciado em Letras - Universidade Estácio de Sá - UNESA/BA e Pedagogia - Universidade Salvador - UNIFACS/BA. Especialista em Ensino de Língua Portuguesa: Oralidade e Escrita - Universidade do Oeste Paulista - UNOESTE/SP, Especialista em Metodologias Ativas na Educação - Universidade Uberaba - UNIUBE/MG. Mestrando em Letras - Universidade Santa Cruz do Sul - UNISC/RS. Professor da Rede Pública Municipal de Salvador/BA e Lauro de Freitas/BA.

E-mail: duarte5@mx2.unisc.br

\section{Waldenilson Teixeira Ramos}

Atualmente é terapeuta no serviço de psicologia aplicado da Universidade Federal Fluminense, pesquisador da Universidade

Federal Fluminense, estagiário administrativo da Universidade Federal Fluminense, extensionista da Universidade Federal do Rio de Janeiro, pesquisador da Universidade Federal Fluminense e professor voluntário de redação do Grupo Diversidade de Niterói. Tem experiência na área de Psicologia, com ênfase em Psicologia Social, atuando principalmente nos seguintes temas: negritude, subjetividade, resistência e inclusão.

E-mail: Waldenilsonramos@id.uff.br

Currículo Lattes: http://lattes.cnpq.br/2268223482149159 
www.arcoeditores.com

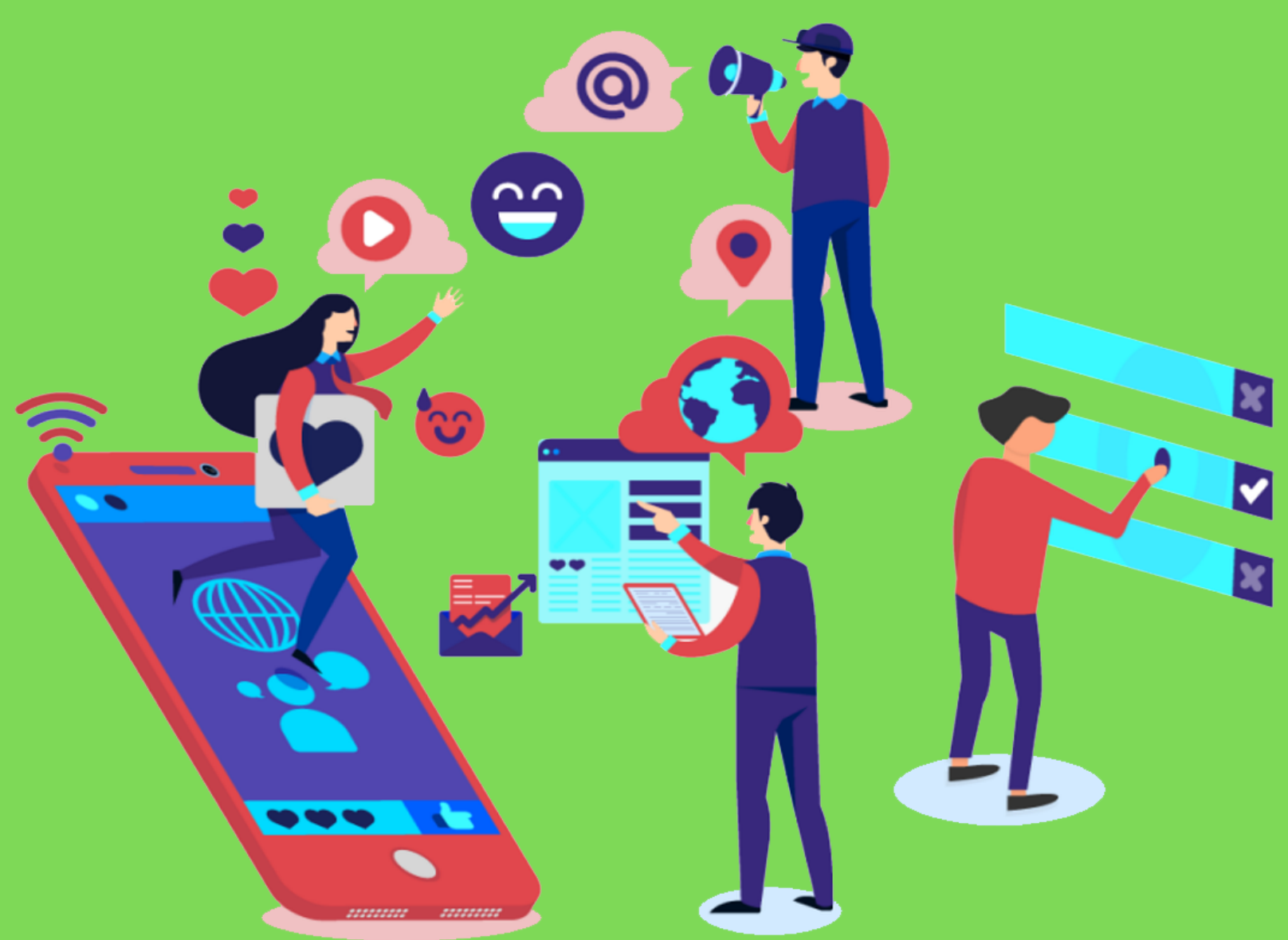

